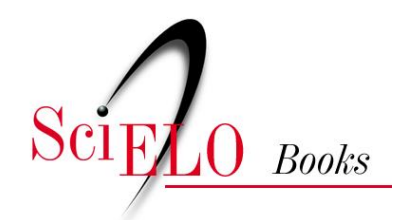

\title{
Tecnologias digitais na educação
}

\author{
Robson Pequeno de Sousa \\ Filomena M. C. da S. C. Moita \\ Ana Beatriz Gomes Carvalho \\ (orgs.)
}

SOUSA, RP., MIOTA, FMCSC., and CARVALHO, ABG., orgs. Tecnologias digitais na educação [online]. Campina Grande: EDUEPB, 2011. 276 p. ISBN 978-85-7879-124-7. Available from SciELO Books $<$ http://books.scielo.org $>$.

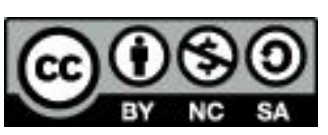

All the contents of this work, except where otherwise noted, is licensed under a Creative Commons Attribution-Non Commercial-ShareAlike 3.0 Unported.

Todo o conteúdo deste trabalho, exceto quando houver ressalva, é publicado sob a licença Creative Commons Atribuição Uso Não Comercial - Partilha nos Mesmos Termos 3.0 Não adaptada.

Todo el contenido de esta obra, excepto donde se indique lo contrario, está bajo licencia de la licencia Creative Commons Reconocimento-NoComercial-CompartirIgual 3.0 Unported. 
Robson Pequeno de Sousa Filomena M. C. da S. C. Moita Ana Beatriz Gomes Carvalho Organizadores

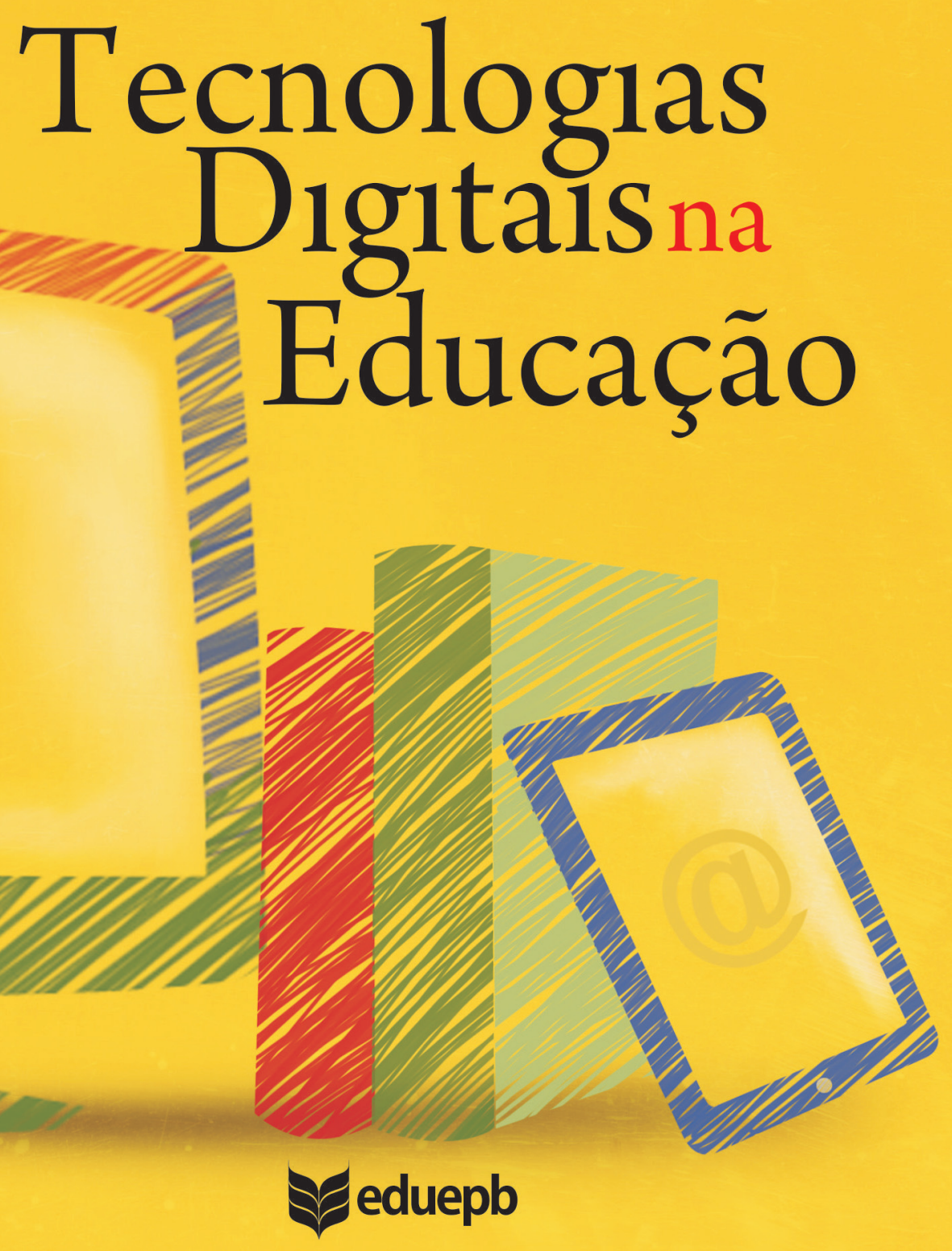


Tecnologias Digitais na Educação 


\section{Universidade Estadual da Paraíba}

Profa. Marlene Alves Sousa Luna

Reitora

Prof. Aldo Bezerra Maciel

Vice-Reitor

\section{Seduepb}

\section{Editora da Universidade} Estadual da Paraíba

\section{Diretor}

Cidoval Morais de Sousa

Coordenação de Editoração

Arão de Azevedo Souza

Conselho Editorial

Célia Marques Teles - UFBA

Dilma Maria Brito Melo Trovão - UEPB

Djane de Fátima Oliveira - UEPB

Gesinaldo Ataíde Cândido - UFCG

Joviana Quintes Avanci - FIOCRUZ

Rosilda Alves Bezerra - UEPB

Waleska Silveira Lira - UEPB

\section{Editoração Eletrônica}

Jefferson Ricardo Lima Araujo Nunes

Leonardo Ramos Araujo

\section{Capa}

Arão de Azevêdo Souza

\section{Ilustração da capa}

Victor Maia de Paula

Comercialização e Divulgação

Júlio Cézar Gonçalves Porto

Zoraide Barbosa de Oliveira Pereira

\section{Revisão Linguística}

Elizete Amaral de Medeiros

\section{Normalização Técnica}

Elisabeth da Silva Araújo 


\section{Robson Pequeno de Sousa}

Filomena M. C. da S. C. Moita

Ana Beatriz Gomes Carvalho

Organizadores

\section{Tecnologias Digitais na Educação}

\section{Aeduepb}

Campina Grande-PB

2011 
Copyright $\odot 2011 \mathrm{do}(\mathrm{s})$ Autor(es)

A reprodução não-autorizada desta publicação, por qualquer meio, seja total ou parcial, constitui violação da Lei nº 9.610/98.

A EDUEPB segue o acordo ortográfico da Língua Portuguesa de 1990, em vigor no Brasil, desde 2009.

Depósito legal na Biblioteca Nacional, conforme decreto $\mathrm{n}^{\circ} 1.825$, de 20 de dezembro de 1907. FICHA CATALOGRÁFICA ELABORADA PELA BIBLIOTECA CENTRAL - UEPB

372.358

T255 Tecnologias digitais na educação/Robson Pequeno de Sousa, Filomena da M. C da S. C. Moita, Ana Beatriz Gomes Carvalho (Organizadores). Campina Grande: EDUEPB, 2011.

$276 \mathrm{p}$.

ISBN: 978-85-7879-065-3

1. Tecnologia da Educação. 2. Multimídia na educação. I. SOUZA, Robson P. de. II. MOITA,Filomena da M. C. da S. C. 4. Direito Econômico. III. CARVALHO, Ana Beatriz G..

21 ed. CDD

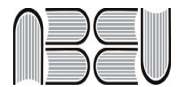

Editora filiada a ABEU

\section{EDITORA DA UNIVERSIDADE ESTADUAL DA PARAÍBA}

Rua Baraúnas, 351 - Bodocongó - Bairro Universitário - Campina Grande-PB - CEP 58429-500 Fone/Fax: (83) 3315-3381 - http://eduepb.uepb.edu.br - email: eduepb@uepb.edu.br 


\section{Agradecimentos}

Somos extremamente gratos à Professora Marlene Alves, Reitora da Universidade Estadual da Paraíba, pelo apoio e motivação desta realização. Agradecemos à Professora Eliane Moura, Coordenadora da CIPE, pela força e atitude decisivas na implementação da primeira turma de Especialização em Novas Tecnologias na Educação, bem como pela contribuição na publicação deste livro. Além disso, agradecemos, também, à Professora Maria Divanira de Lima Arcoverde pela revisão cuidadosa desta produção.

Agradecemos, de forma calorosa, às professores Ana Beatriz e Filomena Moita que, formando uma ciranda comigo, contribuíram juntamente com seus orientandos na produção dos artigos que deram forma a esta publicação. Nossos agradecimentos vão, ainda, para os professores Leandro Dias da Silva, Giovani Farias e Evandro de Barros Costa, por terem contribuído e enriquecido os componentes curriculares da nossa Especialização.

Com especial atenção, externamos a nossa gratidão a todos os alunos da primeira turma que participaram conosco desta caminhada, no Curso de Especialização em Novas Tecnologias na Educação. Por fim, estendemos os nossos agradecimentos a todos que contribuíram de forma direta e indireta na elaboração deste livro.

Prof.Dr. Robson Pequeno

Organizador 



\section{Sumário}

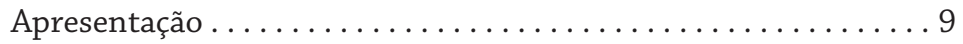

Multimídia na educação: o vídeo digital

integrado ao contexto escolar . . . . . . . . . . . . 17

Desenvolvimento e avaliação de sistema multimídia

para ensino e aprendizado em topografia . . . . . . . . . . . . 49

Novas tecnologias e pessoas com deficiências:

a informática na construção da sociedade inclusiva?. . . . . . . . 73

Os jogos como contextos curriculares:

um estudo das construções de gênero no "The SIMS" . . . . . . . 103

A tecnologia e o ensino de química:

jogos digitais como interface metodológica. . . . . . . . . . . . . . 129

Moodle no curso de ciências biológicas a distância:

análise das contribuições no processo

de ensino e aprendizagem . . . . . . . . . . . . . 153

O sociointeracionismo no contexto da EAD:

a experiência da UFRN . . . . . . . . . . . . . . . . . . 175 
As concepções de interatividade nos ambientes virtuais de aprendizagem...................... 207

Tutoria: concepções e práticas na educação a distância. . . . . . .231

As novas tecnologias da informação e comunicação na perspectiva do ensino de Geografia . . . . . . . . . . . . . 231 


\section{Apresentação}

A construção deste texto sobre o livro "Tecnologias Digitais na Educação" reúne os trabalhos de pesquisa de alunos/professores da $1^{\text {a }}$ turma do Curso de Especialização em Novas Tecnologias na Educação nos permitiu revisitar as experiências iniciais de formação de professores, quando da implantação dos cursos em EAD, momento político- pedagógico em que o Ministério da Educação não abria, ainda, edital de participação para as Universidades Estaduais no Programa de Formação de Professores. A UEPB, então, pela experiência acumulada em projetos de formação de professores em serviço, consorciou-se com a Universidade Federal do Rio Grande do Norte (UFRN) e a Universidade do Estado de Pernambuco (UPE) para oferta dos cursos de licenciatura em Química, Física, Matemática e Biologia.

Estas e muitas outras experiências de formação de professores em serviço têm sublinhado a função Social da UEPB, com marcas de um trabalho que se define pela busca permanente de ampliação da acessibilidade à Universidade para os jovens e adultos da Paraíba, que por múltiplos e diversos motivos não tiveram nem teriam a oportunidade de uma formação universitária.

Neste sentido, a Universidade vem aderindo, nos últimos quatro anos, às Políticas de Formação de professores da Educação Básica das redes públicas, para o Desenvolvimento de Programas de Cursos de Graduação - Presencial e, principalmente, à Distância, 
firmando parcerias entre o Ministério da Educação, por intermédio da Coordenação de Aperfeiçoamento de Pessoal de Nível Superior (CAPES) no âmbito da Universidade Aberta do Brasil (UAB).

A Educação a Distância é uma realidade desafiadora na formação de profissionais da educação e uma das maiores preocupações das agências formadoras deverá ser como preparar professores com qualidade e experiências para ensinar a distância. Esta nova forma de pensar a formação de professores pressupõe outras perspectivas de mundo para o processo de construção do conhecimento.

A palavra "perspectiva” aqui anunciada não remonta apenas ao significado dicionarizado de Aurélio" ${ }^{1}$, "a arte de representar os objetos [...] sob o qual uma coisa se apresenta ou sobre seu ponto de vista, expectativa, esperança. [...] Mas, significa ao mesmo tempo enfoque, perspectiva política, possibilidade e crença em acontecimentos considerados prováveis e bons [...]". Assim, falar em perspectiva no mundo hoje para a educação a distância, é falar de esperança no futuro, é fazer um balanço sobre práticas e teorias educacionais que atravessaram os tempos, se expandem com a vida e não é neutra.

Estes princípios nos lembram Silva² (2001, p.37), quando afirma que:

O impacto das transformações de nosso tempo obriga a sociedade, e mais especificamente os educadores, a repensarem a escola, a repensarem a sua temporalidade. E continua. Vale dizer que precisamos estar atentos

1 FERREIRA, A. B. de H. Novo Dicionário da Língua Portuguesa. 2. ed. Rio de Janeiro: Nova Fronteira, 1986.

2 SILVA, Mozart Linhares da. A urgência do tempo: novas tecnologias e educação contemporânea. In: (org.) Novas Tecnologias: educação e sociedade na era da informática. Belo Horizonte: Autêntica, 2001. 
para a urgência do tempo e reconhecer que a expansão das vias do saber não obedece mais a lógica vetorial. É necessário pensarmos a educação como um caleidoscópio, e perceber as múltiplas possibilidades que ela pode nos apresentar, os diversos olhares que ela impõe, sem contudo, submetê-la à tirania do efêmero.

Este tem sido um dos princípios basilares da política de formação em educação a distância que a Universidade Estadual da Paraíba vem assumindo em suas ações nesta área, com oferta de cursos de graduação e pós-graduação lato-sensu, planejados por um corpo docente que se dedica na construção de projetos políticos pedagógicos e produção de materiais impressos e online privilegiando a atualização de conteúdos por meio de recursos tecnológicos como a internet, as teleconferências e outros veículos que permitem a realização de foro, de chats, e tantas outras formas de veiculação virtual em busca de assegurar efetivamente a interatividade do aluno com o professor e o corpo de tutoria, independente das distâncias geográficas em que se encontrem.

Dessa forma, foi pensado o I Curso de Especialização em Novas Tecnologias na Educação, vinculado ao Programa de Educação a Distância e ofertado pela Coordenação Institucional de Programas Especiais da UEPB. Os artigos aqui organizados pelo professor Dr. Robson Pequeno do Departamento de Matemática, Estatística e Computação e coordenador do curso trazem uma reflexão acadêmica sobre novas perspectivas de educação, fruto de um processo de investigação de alunos/professores da UEPB e da rede Pública Estadual e Municipal de Ensino, que constituíram a $1^{\mathrm{a}}$ turma de Especialização dentro do Programa de Capacitação Continuada de Professores.

De sorte que, os gêneros discursivos aqui apresentados são resultados de avaliação individual e final do Curso, por isso mesmo 
são singulares. As temáticas apresentadas sinalizam para os questionamentos e inquietações dos alunos/professores acerca de suas práticas pedagógicas, das metodologias, das instituições escolares e da função social em EAD. Há, portanto, uma riqueza de temas e abordagens que podem ser lidos em qualquer ordem, e nos permitem abstrair de forma geral, princípios, conteúdos, objetivos e as novas perspectivas teóricas e práticas da educação a distância.

O primeiro texto intitula-se "Multimídia na Educação: o Vídeo Digital Integrado ao Contexto Escolar" de Maria Lúcia Serafim e Robson Pequeno de Sousa. Os autores apresentam o resultado de uma pesquisa que realizaram com alunos do primeiro ano do ensino médio, com intervenção na prática docente em uma escola da rede particular da cidade de Campina Grande - PB. A pesquisa foi fundamentada na teoria da aprendizagem multimídia de Richard Mayer na qual a autora faz uso do vídeo digital como mediação na motivação e aprendizagem do aluno.

Em seguida, Cláudio Silva Soares e Robson Pequeno de Sousa abordam o "Desenvolvimento e Avaliação de Sistema Multimídia para Ensino e Aprendizado em Topografia", pesquisa realizada a partir do desenvolvimento, aplicação e avaliação de um software educacional sobre topografia utilizando recursos de multimídia interativa, cujo objetivo é potencializar o processo não só de aquisição do conhecimento, mas também, de reforçar habilidades que estimule o desenvolvimento cognitivo do aluno.

De autoria de Lígia Pereira dos Santos e Robson Pequeno de Sousa temos o artigo "Novas Tecnologias e Pessoas com Deficiência: A Informática na Construção da Sociedade Inclusiva." que apresenta as novas tecnologias da educação como um instrumento de inclusão social da pessoa com deficiência, evidenciando resultados que mostram a necessidade de mapear e conhecer as Novas Tecnologias da Informação. 
“Os Jogos como Contextos Curriculares: Um estudo das Construções de Gênero no 'THE SIMS", artigo de autoria de Anita Leocádia Pereira dos Santos e Filomena M. G. da S. C. Moita expõe o resultado de um trabalho em que os autores evidenciam a necessidade de se desenvolverem pesquisas com o objetivo de se compreender as especificidades de tal fenômeno, para um melhor entendimento e aproveitamento de sua utilidade pedagógica. Para a delimitação do estudo, foi eleito o game "The Sims 2" como contexto educacional, destacando-se a investigação do respectivo ideário de gênero perpassado em sua trama. Configurando-se em importante texto para aqueles que buscam o campo de pesquisa educacional, inserido nos estudos sobre educação e tecnologias.

Já o artigo "A Tecnologia e o Ensino de Química: Jogos Digitais como Interface Metodológica" de Érika Rossana Passos de Oliveira Lima e Filomena M. G. da S. C. Moita destaca o jogo adivinhas da tabela periódica, com base em propriedades e características dos elementos químicos, bem como a sua presença no cotidiano na estrutura da tabela, na perspectiva de criar um diferencial didáticopedagógico por meio de um direcionamento metodológico inovador, objetivando apresentar a importância do jogo digital adivinhas da tabela periódica e sua contribuição para o ensino de química.

A seguir, encontra-se o artigo de Ana Lígia Passos de Oliveira Costa e Filomena M. G. da S. C. Moita, "Moodle no Curso de Ciências Biológicas a Distância: análise das contribuições no processo de ensino e aprendizagem" que discorre sobre educação a distância como uma das modalidades de ensino e aprendizagem mediada por suportes tecnológicos digitais e de rede, seja inserida em sistemas de ensino presenciais mistos ou completamente realizada por meio da distância física. Nessa perspectiva, este texto analisa como as ferramentas tecnológicas do ambiente Moodle, utilizadas no Curso de Licenciatura em Ciências Biológicas, na modalidade a distância, da Universidade Estadual de Pernambuco (Polo de Campina Grande / UEPB), vêm facilitando o processo de aprendizagem. 
Maria Dalva de Oliveira Araujo e Ana Beatriz Gomes de Carvalho nos contemplam com o artigo O Sociointeracionismo no Contexto da EaD: a experiência da UFRN, discorrendo sobre as concepções pedagógicas que fundamentam a construção dos materiais didáticos utilizados nos cursos a distância, baseadas em pressupostos sociointeracionistas nos Cursos de Licenciatura a Distância, oferecidos pela UFRN na cidade de Campina Grande, na Paraíba. Para a análise, as autoras utilizaram as leituras e os pressupostos teóricos trabalhados na disciplina Educação e Realidade, numa tentativa de estabelecer a relação destes com a prática pedagógica desenvolvida.

A seguir, as autoras Maria das Graças Barros e Ana Beatriz Gomes de Carvalho, abordam "As Concepções de Interatividade nos Ambientes Virtuais de Aprendizagem" analisando o Ambiente Virtual de Aprendizagem, por meio da investigação das ferramentas pedagógicas disponíveis no Moodle, recorrendo a uma abordagem do conceito de interatividade, identificando possíveis dificuldades dos alunos do curso de Administração a distância da UEPB, ao usarem as ferramentas de aprendizagem colaborativa.

O artigo intitulado "Tutoria: Concepções e Práticas na Educação a Distância", construído por Mayan de Andrade Bezerra e Ana Beatriz Gomes de Carvalho levanta uma questão importante sobre a estrutura dos cursos a distância, tendo como suporte uma análise do papel do tutor, profissional que atua diretamente com os alunos e cuja função ainda necessita de mais clareza de suas atribuições. Assim indagam as autoras: Afinal, qual é realmente o papel do tutor? Ele é orientador, conselheiro, motivador ou mediador? Frente a essas indefinições conceituais das atribuições da tutoria, o artigo analisa as concepções e práticas da tutoria nos cursos a distância da UEPB.

Por fim, o artigo de Daniel de Brito Ricarte e Ana Beatriz Gomes de Carvalho, "As Novas Tecnologias da Informação e Comunicação na Perspectiva do Ensino de Geografia" tem como foco o ensino de 
Geografia na sociedade informacional globalizada e a importância das NTICs, como ferramentas didático-tecnológicas, no sentido de tornar a aula de Geografia mais dinâmica, interessante e interativa para o aluno. O autor, então, propõe a construção de um portal digital "Geografia Online' e 'um site didático-digital' que vise promover e socializar digitalmente o uso das NTICs, junto aos professores e alunos de Geografia.

Com estas breves enunciações do que trata cada gênero, fazemos um convite a leitura do livro, Tecnologias Digitais na Educação, que traz uma reflexão acadêmica, fruto de um processo de investigação de professores da UEPB e da rede pública estadual e municipal de ensino sobre a importância da formação de professores, numa perspectiva de Educação a Distância, de inclusão social e de compromisso com os avanços tecnológicos, exigências do mundo moderno.

Profa. Eliane de Moura Silva Coordenadora da CIPE 



\title{
Multimídia na educação: 0 vídeo digital integrado ao contexto escolar
}

\author{
Maria Lúcia Serafim ${ }^{3}$ \\ UEPB - Campina Grande, Paraíba \\ maluserafim@gmail.com \\ Robson Pequeno de Sousa ${ }^{4}$ \\ UEPB - Campina Grande, Paraíba \\ robson.pequeno@gmail.com
}

\section{Introdução}

A sociedade que se configura exige que a educação prepare o aluno para enfrentar novas situações a cada dia. Assim, deixa de ser sinônimo de transferência de informações e adquire caráter de

3 Pedagoga, habilitada em Supervisão Escolar, Psicologia Educacional e em Novas Tecnologias, Mestra em Ciências da Sociedade com estudo na formação do professor para a cultura informática. Professora do Departamento de Educação - CEDUC na Universidade Estadual da Paraíba - UEPB. Atua no CCT no Curso de Licenciatura em Computação.

4 Este artigo é fruto do estudo monográfico realizado em 2008 orientados pelo Prof. Dr. Robson Pequeno de Sousa, Ciências da Computação, Coordenador do Curso de Especialização em Novas Tecnologias da UEPB. 
renovação constante. A escola de hoje é fruto da era industrial, foi estruturada para preparar as pessoas para viver e trabalhar na sociedade que agora está sendo convocada a aprender, devido às novas exigências de formação de indivíduos, profissionais e cidadãos muito diferentes daqueles que eram necessários na era industrial.

Desse modo, é de se esperar que a escola, tenha que "se reinventar”, se desejar sobreviver como instituição educacional. É essencial que o professor se aproprie de gama de saberes advindos com a presença das tecnologias digitais da informação e da comunicação para que estes possam ser sistematizadas em sua prática pedagógica. A aplicação e mediação que o docente faz em sua prática pedagógica do computador e das ferramentas multimídia em sala de aula, depende, em parte, de como ele entende esse processo de transformação e de como ele se sente em relação a isso, se ele vê todo esse processo como algo benéfico, que pode ser favorável ao seu trabalho, ou se ele se sente ameaçado e acuado por essas mudanças.

A educação no mundo e a brasileira vêm sofrendo novas intervenções nestes mais recentes 10 (dez) anos, no tocante à presença e implementação de tecnologias recentes na educação. No Brasil, nas escolas públicas, pode-se citar o ProInfo ${ }^{5}$, como presença de uma Política Federal para informatizar as escolas e formar professores. Mas somente a introdução dos computadores na escola não é suficiente, para que a prática pedagógica possa ser resignificada, quando a questão é o estabelecimento de uma relação diferente

5 O Proinfo é um programa educacional que visa à introdução das Novas Tecnologias de Informação e Comunicação na escola pública como ferramenta de apoio ao processo ensino-aprendizagem. O ProInfo é uma iniciativa do Ministério da Educação, por meio da Secretaria de Educação a Distância SEED, criado pela Portaria n .522 , de 09 de abril de 1997, sendo desenvolvido em parceria com os governos estaduais e alguns municipais.As diretrizes do Programa são estabelecidas pelo MEC e pelo CONSED (Conselho Nacional de Secretários Estaduais de Educação). 
com o conhecimento e com a sociedade. E isso passa evidentemente pela formação contínua de educadores.

O estudo alicerçou-se na contribuição nacional e estrangeira que tratam e consideram as tecnologias digitais como potencializadoras de novos textos ${ }^{6}$, novas formas de pensar, novas práticas pedagógicas, portanto dando lugar à multimídia na educação baseada em produção e desenvolvimento, autoria e potencialidade e ao uso do vídeo digital na educação nesta contextualização de aprendizagem multimídia, gerando projetos e investigações, exploração de aplicativos disponíveis na rede virtual.

Desse modo, o estudo teórico aliado ao de investigação do campo de pesquisa fundamentou-se nas experiências e publicações de estudiosos como: Mayer (2005) que trata da aprendizagem multimídia em sua pesquisa quando a define como aprendizagem das palavras (por exemplo, texto falado ou impresso) e imagens (por exemplo, ilustrações, fotografias, mapas, gráficos, imagem ou vídeo; Lévy (1993) ao conceber a interface na informática afirmando que "não é possível deduzir nenhum efeito social ou cultural da informatização, baseando-se em uma definição pretensamente estável dos autômatos digitais"( LÉVY, 1993, p. 177).

Já em torno da necessidade do redimensionamento da prática do professor numa sociedade onde o conhecimento não é mais o fruto de sua autoria somente Silva (2000, p. 217) aponta reflexões em torno da sala de aula interativa e faz uma análise sobre "as confusas formas de se utilizar o computador numa concepção de

6 No sentido de que como enfatiza Lévy (1993, p.40) "os sistemas cognitivos podem então transferir ao computador a tarefa de construir e de manter em dia representações que eles antes deviam elaborar com os fracos recursos de sua memória de trabalho, ou aqueles, rudimentares e estáticos, do lápis e do papel. Os esquemas, mapas ou diagramas interativos estão entre as interfaces mais importantes das tecnologias intelectuais de suporte informático" "o hipertexto ou a multimídia adequam-se particularmente aos usos educativos" 
reprodução do ensino enciclopédico que dá lugar à centralidade do professor"; Freire (1996, p. 88) afirma que "um dos saberes necessários à prática educativa é o que adverte da necessária promoção da curiosidade espontânea para a curiosidade epistemológica”.

O que se vem afirmando na literatura e na experiência até aqui construída é que no cenário escolar integrado com vivências em multimídia, estas geram: a dinamização e ampliação das habilidades cognitivas, devido à riqueza de objetos e sujeitos com os quais permitem interagir; a possibilidade de extensão da memória e de atuação em rede; ocorre a democratização de espaços e ferramentas, pois estas facilitam o compartilhamento de saberes, a vivência colaborativa, a autoria, co-autoria, edição e a publicação de informações, mensagens, obras e produções culturais tanto de docentes como discentes. É o que Moran (1995, p.27) enfatiza quando expressa que "o vídeo é sensorial, visual, linguagem falada, linguagem musical e escrita. Linguagens que interagem superpostas, interligadas, somadas, não separadas. Daí a sua força”.

Acrescenta-se que as teorias e práticas associadas à informática na educação vêm repercutindo em nível mundial, justamente porque as ferramentas e mídias digitais oferecem à didática, objetos, espaços e instrumentos capazes de renovar as situações de interação, expressão, criação, comunicação, informação, e colaboração, tornando-a muito diferente daquela tradicionalmente fundamentada na escrita e nos meios impressos.

Encontra-se nesta perspectiva, a possibilidade para que professores da Educação Básica e de outros mais variados níveis de ensino, possam rever concepções de sustentação de suas práticas cotidianas, terem acesso e apropriem-se de conhecimentos necessários para trabalharem com a produção de vídeos digitais na sala de aula ou outras interfaces nas diversas disciplinas escolares, com vistas a propiciar motivação e aprendizagem. 
Diante do exposto, acredita-se que experiências nesse campo de estudo são de grande valor pedagógico e de motivação para alunos e professores. Com a mediação das ações pelo professor, que deve estar sempre aberto ao diálogo, os estudantes podem produzir conhecimento numa linguagem próxima de sua realidade, utilizando-se da criatividade e valorização do que cada um sabe nessa ação coletiva.

O estudo foi exploratório, descritivo, quanti-qualitativo e de intervenção ${ }^{7}$ junto aos 32 alunos de $1^{\circ}$ ano do ensino médio e 01 professora de Biologia de uma escola da Educação Básica na cidade de Campina Grande, no sentido de incentivá-la a incorporar em sua metodologia, nos temas de estudo do período escolar a produção de vídeos digitais na etapa de pesquisa e revisão do assunto, com os seus alunos. Como também inserir o aluno numa vivência didática com multimídia, tendo em vista, integrar aplicativo e conteúdo de Biologia na construção das etapas de conhecimento, e nesta perspectiva propiciar a apropriação da ferramenta multimídia, satisfação e motivação dos alunos com o uso do aplicativo e a aprendizagem do conteúdo de Biologia.

Escolheu-se esta disciplina, por apresentar uma densa programação curricular na série que envolve conceitos e definições complexas, agregação de informações e ainda pelo fato de, por vezes, professores se queixarem no cotidiano escolar dos resultados da aprendizagem e do modo insuficiente como os alunos estudam, implicando certa insatisfação na qualidade da aprendizagem desejada.

7 Na pesquisa-intervenção a expectativa está vinculada à multiplicação de questões que nos permitem explorar outros caminhos com a comunidade envolvida. Este é o índice de movimento, já que a instituição escolar não existe fora da realidade sócio-histórica. Segundo Veiga Neto (1996), o desafio dos pesquisadores é ultrapassar as representações que estruturam as tradições e hábitos da comunidade investigada, os consensos estabelecidos que naturalizam o cotidiano nos seus valores, produções e expectativas em busca do movimento. 
As questões do estudo focaram: O rompimento com práticas pedagógicas alicerçadas na linearidade, para que outras possam fazer eclodir novas e significativas aprendizagens para alunos e professores; e ainda que orientados pelo professor os alunos possam desenvolver habilidades cognitivas, na aprendizagem multimídia para construção de vídeos digitais com conteúdos escolares favorecendo a formação do novo perfil discente, mais cidadão e antenado com as exigências de seu tempo.

A rapidez das inovações tecnológicas nem sempre correspondem à capacitação dos professores para a sua utilização e aplicação, o que muitas vezes, resulta no uso inadequado ou na falta de criação diante dos recursos tecnológicos disponíveis, mas não tendo mais o monopólio da transmissão de conhecimentos, exige-se à escola e ao professor, em particular, a função social de orientar os percursos individuais no saber e contribuir para o desenvolvimento de competências, habilidades e cidadania.

\section{Aspectos teóricos - metodológicos do estudo}

$\mathrm{Na}$ educação contemporânea o professor não é visto como a fonte de todo o conhecimento e o conhecimento não é um objeto, algo que possa ser transmitido do professor para o aluno. Contudo, ainda hoje, em muitas escolas, predomina a comunicação vertical, o professor é o detentor do saber absoluto, agindo como um transmissor de conhecimento e não permitindo que o aluno discuta suas idéias e traga novas informações para a sala de aula. Muitos professores não levam em conta a experiência que os alunos já trazem consigo e não estimulam a discussão sobre o que eles aprendem em casa, na rua, na TV, no rádio, revistas e Internet.

Os meios de comunicação informática, revistas, televisão, vídeo têm atualmente grande poder pedagógico visto que se 
utilizam da imagem e também apresentam conteúdo com agilidade e interatividade.

Assim, torna-se cada vez mais necessário que a escola se aproprie dos recursos tecnológicos, dinamizando o processo de aprendizagem. Como a educação e a comunicação são indissociáveis, o professor pode utilizar-se de um aparato tecnológico na escola visando à transformação da informação em conhecimento.

\section{Multimídia e vídeo digital no ensino e aprendizagem}

A expressa necessidade de um maior envolvimento entre as áreas tecnológica e educacional é cada vez mais evidente. Hoje, a relação educação e tecnologia é presente em quase todos os estudos que analisam o contexto educacional. Grinspun (1999), aponta que educação e políticas de ciências e tecnologia, ocupam lugar de centralidade nas decisões políticas em termos de qualificação dos recursos humanos, exigência de novos padrões de desenvolvimento.

O espaço educativo escolar deveria ser constituído de ambientes de troca de saberes e construção de reflexões e práticas transformadoras. No entanto, os alunos, muitas vezes, não encontram um ambiente em que possam discutir suas idéias e participar do ato de aprender, mutuamente. Um dos problemas mais debatidos quando se fala em escola e os jovens de hoje é justamente o distanciamento que há entre a cultura escolar e a cultura da juventude. Os conteúdos e conceitos aprendidos em sala de aula muitas vezes não fazem sentido para estes jovens que almejam um futuro que na maioria das vezes não está ligado ou relacionado com o que vêem nas salas de aula.

Acredita-se que um dos principais motivos deste distanciamento é a falta de espaços comunicativos na escola, que certamente permitiriam uma maior participação dos discentes. Por isso, diante 
da complexidade da cultura juvenil, é necessário aos ambientes educacionais instaurar espaços de negociação entre educadores e educandos, possibilitando uma troca de posições e visões de mundo que permitam uma aproximação entre estas duas culturas num mundo de aprendizagem e cultura digital.

A escola, para fazer cumprir sua responsabilidade social de educar e formar os novos cidadãos precisa contar com professores que estejam dispostos a captar, a entender e a utilizar as novas linguagens dos meios de informação e comunicação a serviço de sua prática pedagógica que deve ser compreendida como uma forma específica de práxis, portanto, prática social que envolve teoria e prática, própria da prática educativa. Como afirmou Freire (1991, p. 109) "praticar implica programar e avaliar a prática. E a prática de programar que se alonga na de avaliar a prática, é uma prática teórica”.

Assim, entende-se que a sala de aula não é o único lugar onde ocorre a aprendizagem e que a comunicação pode proporcionar, através de variados meios, a formação de diferentes ambientes de aprendizagem e uma maior participação dos alunos nas relações de ensino.

A concepção de aprendizagem exaustivamente disseminada nos dias de hoje ressalta o quão importante são as interações entre sujeitos e objetos para a aprendizagem. Para Silva (2000) a pedagogia interativa é uma proposta que valoriza o papel do professor como mediador de novas e recorrentes interações e encorajador da rede de conhecimentos que os alunos constroem e do desenvolvimento de novas competências comunicativas.

Apesar dos discursos inquietantes e iniciativas já existentes, assiste-se a uma situação extremamente paradoxal: enquanto as crianças e jovens interagem com mais informações audiovisuais e meios eletrônicos do que com mídias impressas, vivendo em um mundo permeado pelas tecnologias digitais, seus professores 
foram formados para ministrar um ensino baseado em técnicas pedagógicas, conteúdos e materiais convencionais. Muitos educadores acabam apenas reproduzindo os modelos tradicionais de ensino quando propõem atividades com objetos digitais em sala de aula, desconsiderando a transição do paradigma aprendizagem/ sala de aula/escola para aprendizagem/redes sociais/sociedade do conhecimento.

O preparo dos docentes brasileiros para a utilização de mídias e objetos digitais como materiais didático-pedagógicos ainda é insipiente. Lévy (1993) salienta a importância da utilização da multimídia na educação. O autor reforça que todo conhecimento é mais facilmente apreendido e retido quando a pessoa se envolver mais ativamente no processo de aquisição de conhecimento. Portanto, graças à característica reticular e não-linear da multimídia interativa a atitude exploratória é bastante favorecida. "É, portanto, um instrumento bem adaptado a uma pedagogia ativa" (LÉVY, 1993, p. 40).

A multimídia interativa permite uma exploração profunda devido à sua dimensão não linear. Através da multimídia tem-se uma nova estruturação de como apresentar, demonstrar e estruturar a informação apreendida. O computador mediante texto, imagem e som interrompe a relação autor / leitor que é claramente definida num livro, passa para um nível mais elevado, reconfigurando a maneira de como é tratada esta relação. A interatividade proporcionada pelos aplicativos multimídia pode auxiliar tanto na tarefa de ensinar quanto na de aprender.

Mediante estudos de Mayer (2001), quando a mensagem é pobremente desenhada, os alunos têm mais dificuldade em compreendê-la, sendo a carga cognitiva extrínseca elevada, quando a mensagem está bem estruturada e apresentada, a carga cognitiva é minimizada. Afirma que temos que nos envolver ativamente num processamento cognitivo para construirmos uma representação mental coerente. Isso inclui prestar atenção, organizar a nova 
informação e integrá-la no conhecimento existente. Este processo envolve ativar o conhecimento na memória em longo prazo e trazê-lo para a memória em curto prazo. Como resultado dos estudos realizados e dos pressupostos enunciados, Mayer (2000, p. 1-19) propõe sete princípios que devem estar subjacentes à concepção de um documento multimídia:

1. Os alunos aprendem melhor quando se combinam palavras e imagens do que só palavras - princípio multimídia;

2. Quando palavras e imagens correspondentes estão próximas em vez de afastadas, por exemplo, no mesmo écran - princípio de proximidade espacial;

3. Quando palavras e imagens são apresentadas simultaneamente em vez de sucessivamente - princípio de proximidade temporal;

4. Quando palavras, imagens ou sons não relevantes para o assunto são excluídos - princípio de coerência; quando se utiliza animação e narração em vez de animação e texto escrito - princípio de modalidade;

5. Quando se utiliza animação e narração em vez de animação, narração e texto - princípio de redundância;

6. E ainda analisando os sujeitos relativamente aos conhecimentos e à orientação espacial, concluiu que os sujeitos que se beneficiam mais de um documento multimídia são os que têm poucos conhecimentos relativamente e aos que já têm muitos conhecimentos; 
7. Que são os sujeitos que têm elevada orientação espacial que mais se beneficiam comparativamente aos que têm pouca orientação espacial - princípio das diferenças individuais.

Neste contexto, dentre os usuários mais interessados em atividade deste gênero, como o vídeo digital, estão crianças e adolescentes, um público que crescentemente se identifica muito com esse tipo de mídia, dado seu caráter altamente motivacional. Apesar de ser geralmente associada ao lazer e entretenimento a produção de vídeos digitais pode ser utilizada como atividade de ensino e aprendizagem com vasto potencial educacional ainda a ser explorado.

A exploração do vídeo pelas escolas como ferramenta motivacional não é nova, no entanto, existe um mau uso desta produção imagética, na qual muitas vezes é esquecida sua dimensão estética. Ocorre certo reducionismo nesta rica linguagem, hoje extremamente enriquecida pelas funções multimídia. É evidente que significado apenas como ferramenta o vídeo, por si só não ensina ${ }^{8}$. Silva (2000) assinala que o uso do vídeo em sala de aula já acumula uma série de críticas devido ao seu uso adequado e inadequado.

8 Vídeo e computador, considerados de modo separado, podem ser utilizados em sala de aula como possibilidades interativas de produção de aprendizagem e de mobilização do conhecimento. O vídeo não é interativo, já o computador, hipertextual, tem essência interativa. Mas o professor pode inverter a natureza comunicacional de cada um, pois esta pode ser sua opção crítica, sua autoria. Ou seja, o computador pode ser utilizado para reforçar o ditar e transmitir, limitando-se a esta conservação. E o vídeo em sua natureza seqüencial, pode ser utilizado em um ambiente interativo de forma a potencializar expressão e comunicação, pode propor uma ação pedagógica que motiva a aprendizagem. $\mathrm{E}$ com o vídeo digital, compartilhar a aprendizagem que desenvolve um processo de produção de sentido que permite a cada aprendiz construir seu aprendizado na singularidade e ao mesmo tempo na colaboração. 
Moran (1995, p.27) afirma que as potencialidades do vídeo fazem crer que este utensílio também tem uma "interatividade funcional":

O vídeo é sensorial, visual, linguagem falada, linguagem musical e escrita. Linguagens que interagem superpostas, interligadas, somadas, não separadas. Daí a sua força. Somos atingidos por todos os sentidos e de todas as maneiras. O vídeo nos seduz, informa, entretém, projeta em outras realidades (no imaginário), em outros tempos e espaços (MORAN, 1995, p. 27)

Mesmo sem o computador em sala de aula, o professor pode promover interatividade, utilizando as potencialidades do vídeo. Para isso, ele precisa cuidar da "interatividade intencional" e ir se apropriando das possibilidades das interfaces digitais. Portanto, a escolha e exploração do aplicativo movie maker, do seu conteúdo, forma e cognição foi para que os alunos pudessem acessar e interpretar as telas, ícones e objetos, no tocante ao real conteúdo do conhecimento da ferramenta, por ser este já consideravelmente utilizado pelos jovens de modo informal em suas atividades pessoais.

Daí, a possibilidade de que os alunos elaborassem em riqueza e em formato multimídia os conteúdos de Biologia, se orientados no âmbito da prática docente. E este esforço de trabalho se deu na busca de evitar que os aprendizes desenvolvessem uma compreensão superficial do assunto apresentado pelos produtos que estavam a planejar, ou seja, os seus vídeos digitais.

No cenário multimídia, o apoio visual pode também ser apresentado em forma dinâmica e acrescido de som. É possível que este contexto diversificado, permita ao aprendiz estabelecer com mais facilidade, relações entre o insumo oferecido pelo material do professor e o seu conhecimento prévio do assunto. 
Quando as diferentes modalidades expressivas da multimídia são utilizadas de forma integrada pelo professor em seu trabalho pedagógico, estas ações podem favorecer a uma amplitude de possibilidade e sentido para a motivação e aprendizagem do aluno, sendo um fator que pode contribuir para a informação que chega ao aluno, devido aos seus diferentes estilos cognitivos.

\section{Método, participantes e design da pesquisa}

A pesquisa foi exploratória e descritiva, com apoio da estatística descritiva, utilizando para avaliação variáveis do tipo qualitativa e tabelas de distribuição de freqüências; figuras formato de pizza e em barras múltiplas, feitas com o software Excel. Foi realizada em campo escolar na cidade de Campina Grande, nos meses de maio e junho de 2008. Aliou aspectos quantitativos, mediante observação e intervenção direta do pesquisador junto à professora e alunos de $1^{\circ}$ ano do ensino médio para intervenção na prática docente, para tal realizaram-se oficinas de estudo do aplicativo e planejamento dos vídeos, como também observação da convivência e produção multimídia dos grupos de alunos.

Na visão de Lüdke e André (1986, p. 13), a pesquisa qualitativa "envolve a obtenção de dados descritivos, obtidos no contato direto do pesquisador com a situação estudada, enfatiza mais o processo do que o produto e se preocupa em retratar a perspectiva dos participantes".

1. Intervenção inicial, junto à professora para delinear o trabalho pedagógico com vídeosutilizando o aplicativo sugerido mediante a programação dos conteúdos do período "Organelas citoplasmáticas". 
2. Intervenção junto aos 32 alunos do $1^{\circ}$ ano do ensino médio para orientação do aplicativo e proposição pedagógica.

3. Aplicação de questionário com a professora para colher dados que iriam definir a participação dela na pesquisa, tendo o vídeo digital como uma proposta que seria incorporada a sua prática pedagógica.

4. Aplicação de questionários com os alunos em etapas, sendo uma anterior a produção digital, e outra após a produção do vídeo, que transcorreu num período de 15 dias letivos e verificou o nível de satisfação e motivação com o processo de trabalho pedagógico utilizando multimídia através do aplicativo movie maker.

\section{Material e aparatos}

$\mathrm{Na}$ vivência das etapas do trabalho de campo utilizaram-se recursos tecnológicos de mediação como laboratório da escola, sala de aula dos alunos, data show, CDs, câmeras digitais, computador com sistema operacional Windows 2003 e o aplicativo Windows movie maker.

\section{0 aplicatvo Windows Movie Maker}

Enfatizando a descoberta e à criação, a pesquisa e a formação de alunos capazes de construir percursos de aprendizagem, de aprender a aprender - habilidade necessária para toda vida, os estudantes podem utilizar softwares multimídia para subsidiar projetos nas disciplinas escolares e temas diversos. Com ferramentas de multimídia utilizadas diretamente por eles, é possível 
compartilhar informações e representá-las a partir de múltiplas perspectivas, através da combinação de textos, imagens, sons, animações, botões e efeitos, em um ambiente de estímulos multissensoriais. O Windows movie maker é um simples mais bem potente software de edição de vídeo, sendo ainda em parte desconhecido como interface gratuita do sistema operacional Windows.

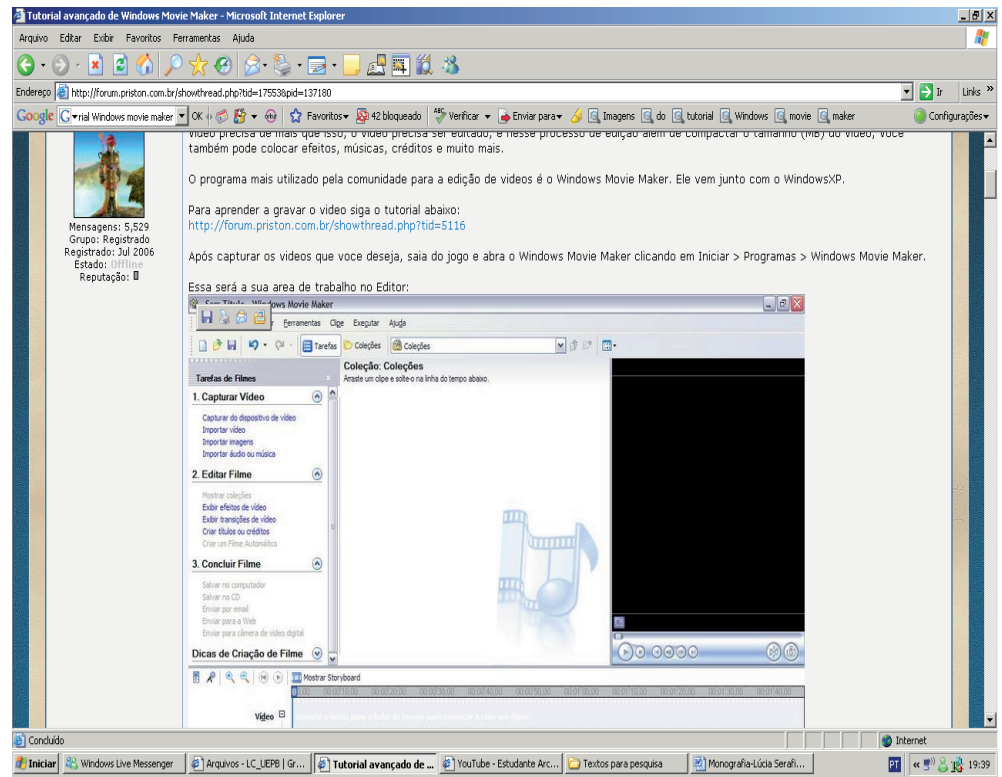

Figura 01 - Área de trabalho do aplicativo Movie Maker

O programa evoluiu imensamente desde sua versão inicial em 2000, incluída no Windows Millennium até a atual versão (2.1) no Windows XP e Windows Vista. Hoje se pode dizer que cobre um alto percentual de uso para as necessidades do chamado cineasta caseiro, permitindo basicamente só com o mouse realizar funções complexas ao criar filmes com trilha sonora, letreiros e efeitos especiais. O programa pode ser usado para organizar vídeos produzidos 
por filmadoras e câmeras fotográficas ou mesmo para montar apresentações com imagens estáticas. Só é preciso ter os clipes de vídeo e as fotos no computador. Após salvo, pode ser visto pelo Windows media player, ou pode ser copiado em $\mathrm{CD}$, pois o movie maker salva os vídeos em formato WMV e AVI. Envolve algumas etapas simples como: transferência de conteúdo para o Windows Movie Maker, editar o projeto, visualizar o projeto, enviar o filme terminado. Sendo preciso para criar um filme: o projeto, organização dos clipes, edição de vídeos, transições de vídeo, efeitos de vídeo, trilha sonora, narrações de voz, títulos e créditos.

\section{Produção}

O grande grupo foi divido em quatro grupos de trabalho e produção para exploração do aplicativo Windows movie maker. Então foi idealizado o projeto a partir de uma estruturação, tendo à mão, no micro, todos os itens para incluir no filmes: clipes de vídeo em arquivos MPG, fotos e músicas MP3 para a trilha sonora. Para narrações de voz, um microfone conectado ao computador, pesquisas de aprofundamento do assunto em estudo "Organelas citoplasmáticas", escolhas de cenas, sons e imagens e estruturação de papeis dos alunos. A etapa de produção suscitou o uso do aparato tecnológico para edição do vídeo e finalização do produto que foi gravado em CDs, resultando em quatro CDs com apresentações multimídias para socialização do conhecimento de Biologia estudado e das experiências colaborativas e de aprendizagem vivenciadas. 


\section{Resultados e discussão}

A intervenção didática na sala de aula apontou que a professora:

1. Deseja aprender e vivenciar novas aprendizagens relacionadas com a tecnologia digital e multimídia, embora não tivesse conhecimento da ferramenta movie maker e nem aprofundamentos na informática educativa;

2. As maiores dificuldades que enfrenta no ensino da disciplina de Biologia no $1^{\circ}$ ano do médio são:

- Os livros didáticos são muito complexos para os alunos;

- que há muito conteúdo para expor;

- grande cobrança advinda do vestibular.

A professora vivenciou os processos de criação de vídeo, produzindo uma vídeo aula de revisão com o aplicativo sugerido. Como afirma Freire (1996, p.38):

a tarefa coerente do educador que pensa certo é, exercendo como ser humano a irrecusável prática de interligar, desafiar o educando com quem se comunica e a quem se comunica, produzir sua compreensão do que vem sendo comunicado. Não há inteligibilidade que não seja comunicação e intercomunicação e que não se funde na dialogicidade. O pensar certo por isso é dialógico e não polêmico. 


\section{Dados obtidos com os alunos na fase anterior à produção do vídeo:}

Os alunos consideram que há bom rendimento em Biologia, num percentual de $44 \%$ pela figura 02 e apontam a orientação da professora como fator relevante à aprendizagem deles em $26 \%$, de acordo com a figura 03 .

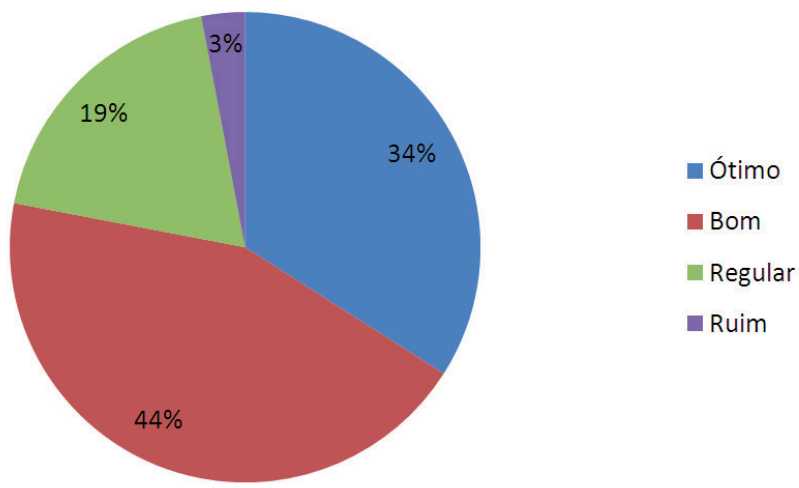

Figura 2 - Resultados comumente obtidos em Biologia
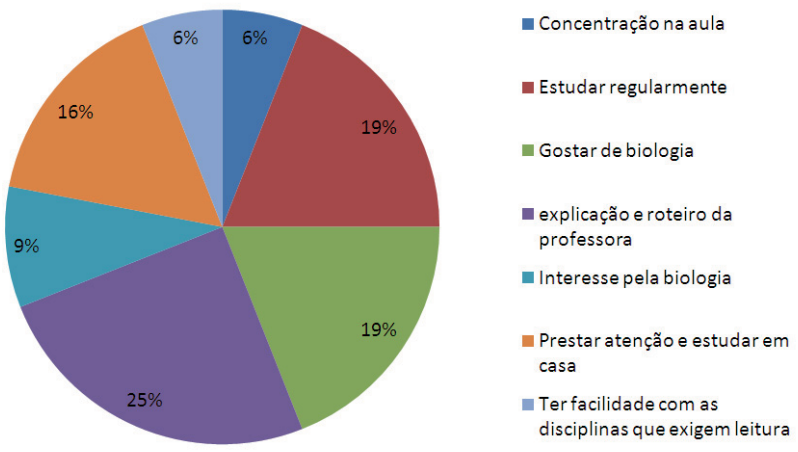

Figura 3 - Fatores que contribuem para resultados satisfatórios em Biologia 
De acordo com as figuras abaixo no tocante à apropriação dos conhecimentos de Informática e Multimídia, os estudantes usam em $100 \%$ o computador conforme figura 04 e em diversos ambientes, sendo em $49 \%$ em casa. Eles afirmam que com o aplicativo movie maker a aula fica mais interessante em 28\%, proveitosa, sendo colaborativa e meio alternativo à aprendizagem num percentual de $28 \%$ conforme figura 06 .

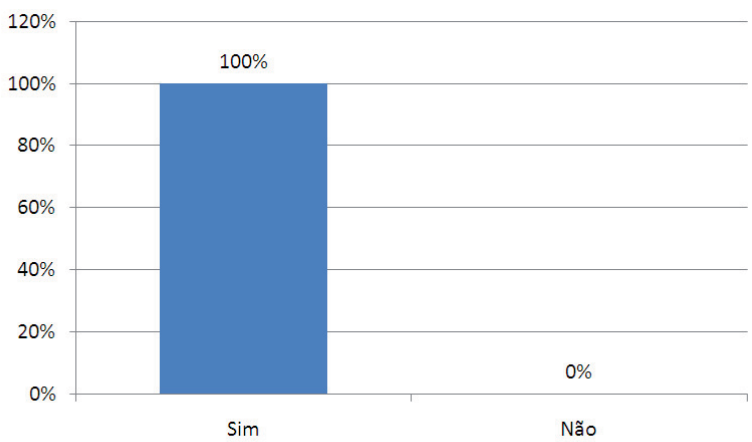

Figura 04 - Percentual de alunos que usam o computador

Figura 04 - Percentual de alunos que usam o computador

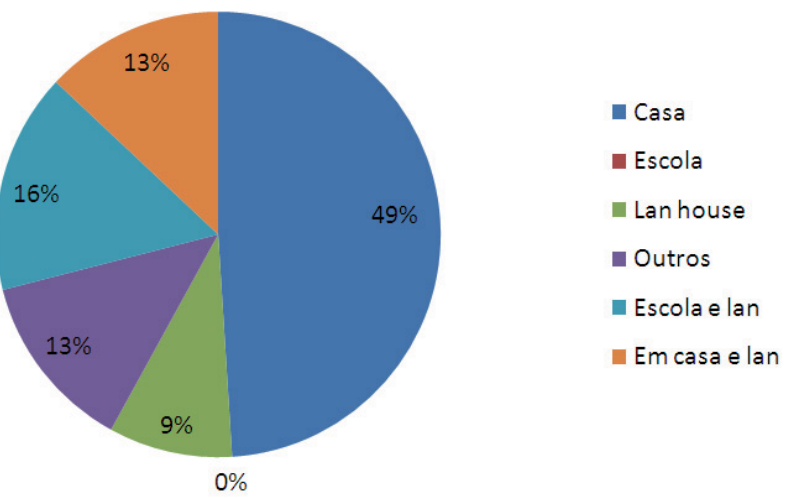

Figura 05 - Local de uso do computador 

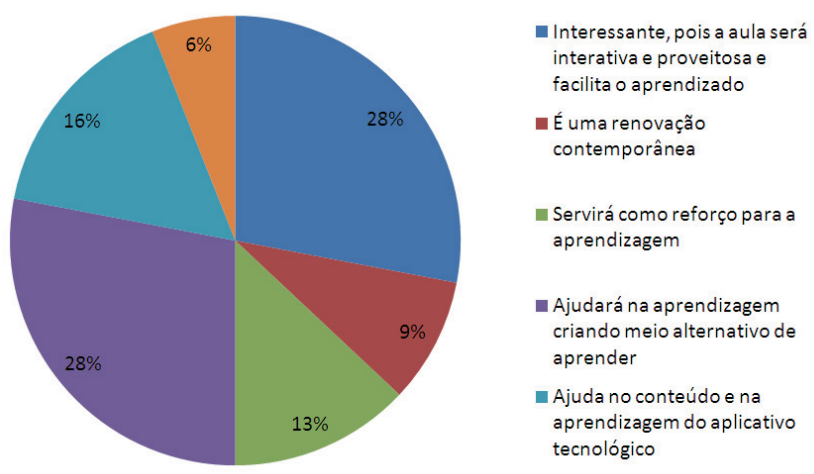

Figura 06 - Uso do aplicativo para produzir vídeo em Biologia

Alarcão (2003) destaca que de repente pensar e agir ativamente não é uma questão fácil nem para educadores nem para os discentes. Relata que algumas experiências foram possíveis referindo-se a três estudos de pesquisa-ação (Vieira, 1998; Carreira, 2000; Gonçalves, 2002), desenvolvidos em Portugal. Os três de intervenção didáticocurricular tiveram como finalidade desenvolver a capacidade de autonomia dos alunos através da estruturação de atividades que estimulem os alunos a serem aprendizes ativos, que aproximem escola e vida, auto-aprendizagem e motivação. 
Dados obtidos com os alunos na fase de Pré - producão, produção e Pós-produção do vídeo de Biologia referente ao conteúdo "Organelas Citoplasmáticas" etapas de revisão, aprofundamento e conclusão do estudo do conteúdo curricular.

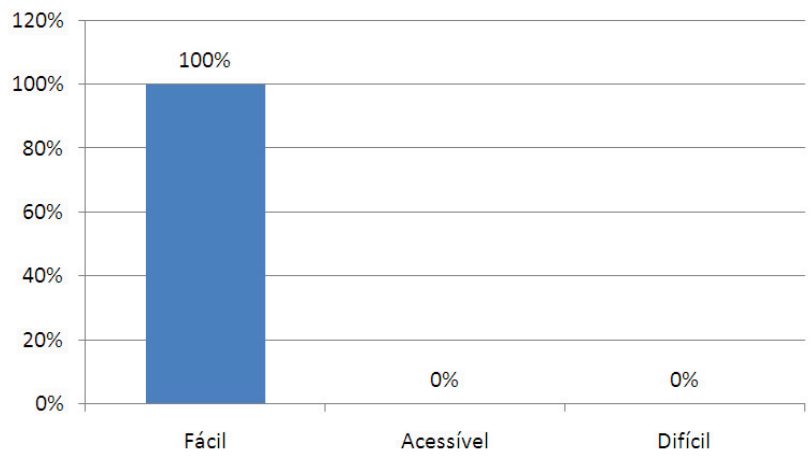

Figura 07 - Uso do Movie Maker

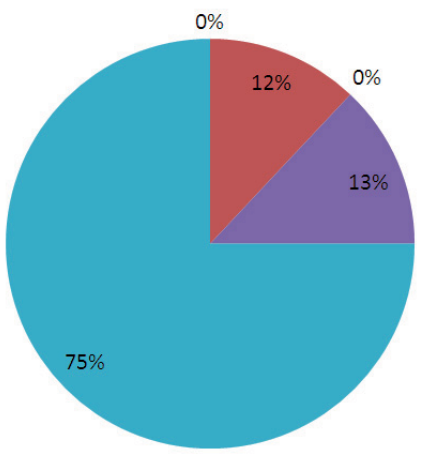

$$
\begin{aligned}
& \text { Wintetizar idéias } \\
& \text { Pesquisar e selecionar com } \\
& \text { crítica } \\
& \text { Selecionar imagens válidas } \\
& \text { - Selecionar texto e imagen } \\
& \text { relacionadas } \\
& \text { Compreender o } \\
& \text { detalhamento do conteúdo }
\end{aligned}
$$

Figura 08 - Em que favoreceu produzir vídeo sobre organelas citoplasmáticas 
Os estudantes afirmaram em $100 \%$ pela figura 07 ser de fácil uso o aplicativo movie maker, e na figura 08 que produzir o vídeo ajudou em $74 \%$ no detalhamento do conteúdo de Biologia organela citoplasmática. Isto foi notadamente expresso quando da mediação do suporte computacional com o conteúdo da disciplina, já que tratou da aprendizagem de conceitos, solução de problemas e o desenvolvimento do projeto do vídeo como produto de trabalho colaborativo. Parece que uma boa parte das competências hoje exigidas são dificilmente ensinadas, contudo, precisam ser desenvolvidas, para Walker (2004), "the digital vídeo appears to have considerable potential as a research tool in educational research"

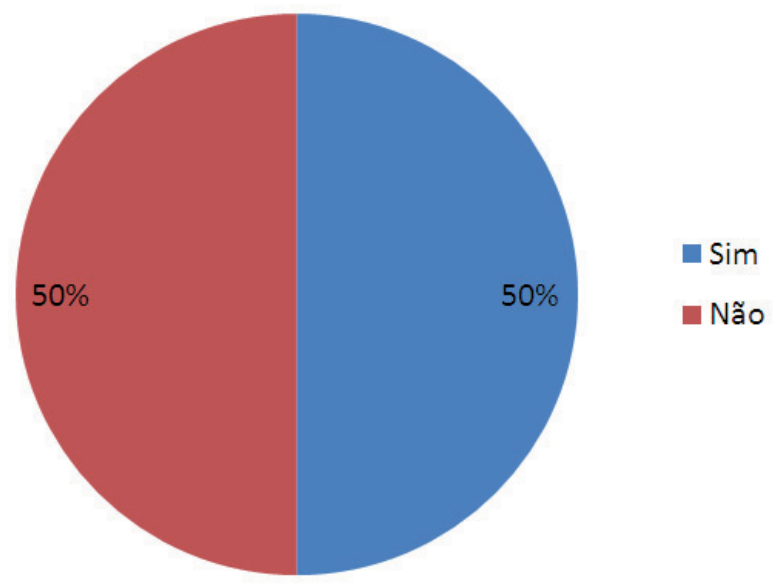

Figura 09 - Preocupação em elaborar projeto

9 O vídeo digital parece ter grande potencial como instrumento de investigação na pesquisa educacional. 


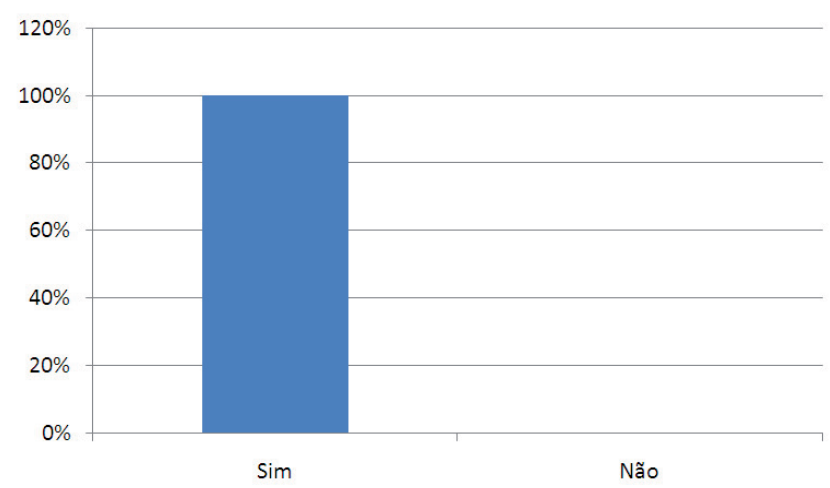

Figura 10 - Preocupação em elaborar cenas, conjunto de cenas e intervalos de tempo

Fase de Pré-produção do vídeo - Foi visível que a interação entre os estudantes era monitorada pelas idéias de colaboração entre pares e conectadas às estações de trabalho pelas quais eles iam interagindo quando da elaboração do projeto do vídeo. Estes dados são apontados pelas figuras 09 e 10, quando os alunos expressam preocupação com o projeto a ser construído.

Quanto à produção do Vídeo - Foi significativa a participação dos grupos de alunos na produção do vídeo, o que responde aos objetivos do estudo quando este tem a crença de que a presença de tecnologias digitais e multimídia na prática docente são possibilidades para a motivação, colaboração e a aprendizagem dos aprendizes. 


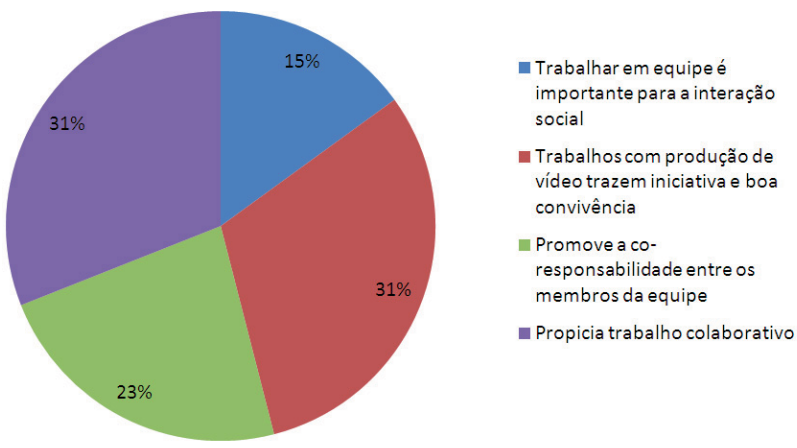

Figura 11 - Opiniões quanto ao trabalho colaborativo

São evidenciadas positivamente as questões colaboração na figura 11, motivação nas figuras 12 e 13 e 14, pois tratam do interesse dos alunos acentuando na figura 14 em $49 \%$ o fato de que a atividade exigiu empenho do aluno em produzir vídeo em Biologia. Buscar estes novos fundamentos permite ao professor uma nova compreensão da realidade, o desenvolvimento de práticas educativas epistemologicamente mais inovadoras e o reconhecimento do aluno como microautor de uma rede de relações e interações estabelecidas com seu meio, de acordo com Lévy (1993).

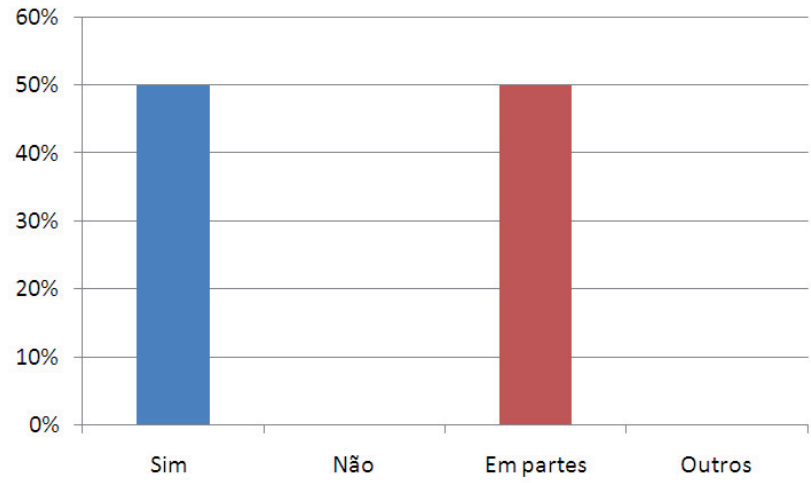

Figura 12 - Produzir vídeo aumento o interesse em Biologia 


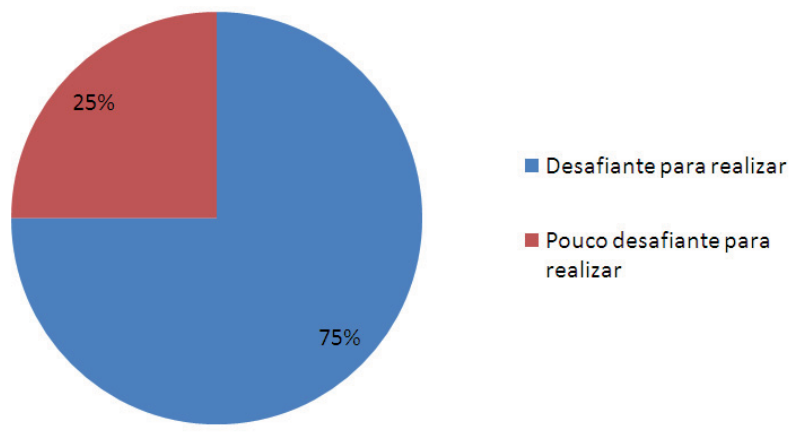

Figura 13 - Interesse pela atividade proposta

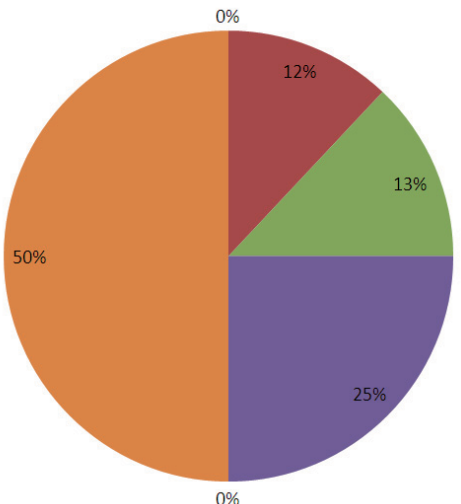

- Trouxe maior gosto pelo tema

- Forma dinâmica de aprender

Bom método para aprender

- Oportunidade do aluno se autodesafiar na busca de imageme texto relativo ao tema

- $\mathrm{O}$ aluno é produtor de um filme

Exigiu o empenho do aluno em produzir filme em biologia

Figura 14 - A atividade foi Desafiante por quê 
Este é um empreendimento que se conduz no referencial teórico como pedagogia cooperativa ${ }^{10}$, ou seja, um contexto de didática colaborativa necessária ao desenvolvimento do grupo no tocante aos aspectos intelectual e afetivo-relacional, favorecendo do ponto de vista construtivista e sócio construtivista a contínua construção e reconstrução do saber.

Experiência com a produção do vídeo - Para o professor, lidar com tecnologias recentes, ora parece um desejo destes, ora preocupação, ora deixam de lado, sabem que o afastamento pode vir a prejudicar sua performance, e a qualidade de seu trabalho, seja pelo desconhecimento das necessidades do aluno, seja pela obsolescência ou impropriedade de currículos, por falta de retorno que lhe permita corrigir distorções. Do ponto de vista do aluno, estes encontram salas de outras possibilidades, o estudante pode estudar em casa, no trabalho ou na praia, além da escola e vai trazendo para o convívio da sala as aprendizagens tecnológicas empreendidas individualmente ou em grupo.

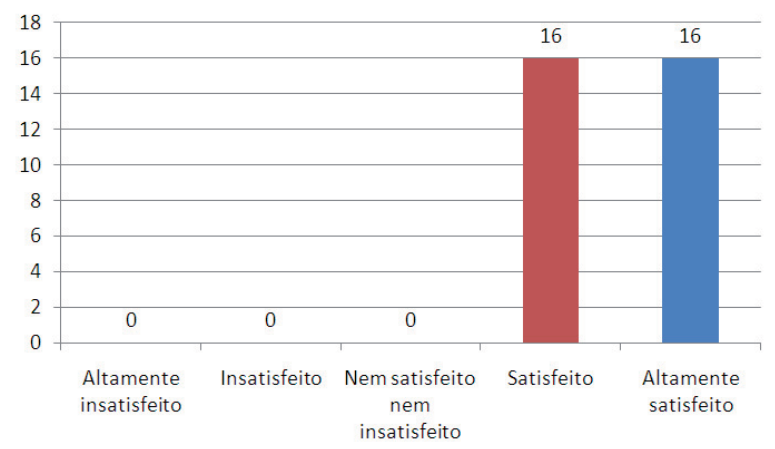

Figura 15 - Nível de satisfação do aluno com a produção do vídeo em Biologia, conferindo-lhe autoria.

10 Sobre este contexto ver leitura do artigo: D’AVILA, C. M.Pedagogia cooperativa e EAD: uma aliança possível. Educação e contemporaneidade, Salvador, v. 12, n. 20, p.273-285, jul./dez., 2003 


\begin{tabular}{c|c|c|c|c|c|c}
\hline & & Número & Mínimo & Máximo & Média & Desvio \\
\hline Altamente insatisfeito & 1 & 0 & 1 & 5 & 0 & 0 \\
\hline Insatisfeito & 2 & 0 & 1 & 5 & 0 & 0 \\
\hline Nem satisfeito nem insatisfeito & 3 & 0 & 1 & 5 & 0 & 0 \\
\hline Satisfeito & 4 & 16 & 1 & 5 & 2,50 & 0,5 \\
\hline Altamente satisfeito & 5 & 16 & 1 & 5 & 2,50 & 0,5 \\
\hline
\end{tabular}

Tabela 01 - Descrição estatística por Score da média do nível de satisfação dos alunos

Para Moran (2007, p. 47) "Há atividades que facilitam a organização e outras a superação". Sobre a utilização de vídeo na escola, apresenta dois focos:

1. Quando o vídeo provoca, sacode, causa inquietação e serve como abertura para um tema, é um estímulo em nossa inércia [...];

2. Quando o vídeo serve para confirmar uma teoria, uma síntese, um olhar específico com o qual já estamos trabalhando, é ele que ilustra, amplia, exemplifica. (MORAN, 2007, p. 47)

O estudo desejou atingir o segundo foco, pela relevância de superação de modelo estabelecido para um mais inovador e pela busca de sistematizar organizações em grupo, motivação para favorecer uma maior aprendizagem. Aprender depende também do aluno, de que ele esteja pronto, maduro, para incorporar a real significação que a informação tem, senão não será apreendida de verdade. 


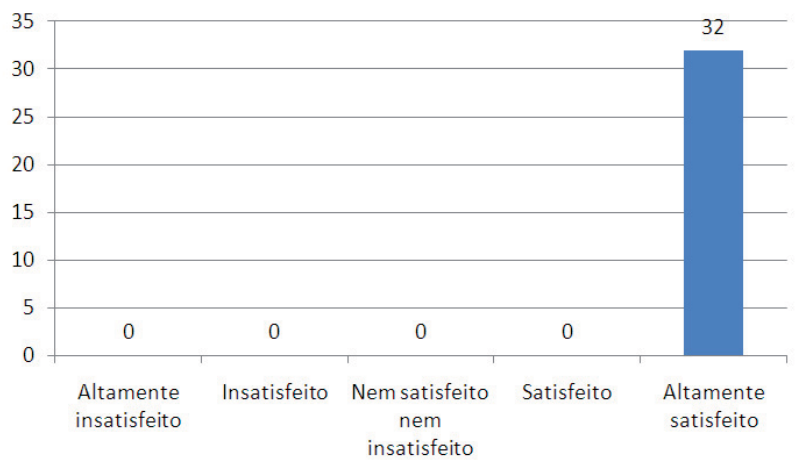

Figura 16 - Nível da satisfação quanto ao trabalho em grupo

\begin{tabular}{c|c|c|c|c|c|c}
\hline & & Número & Mínimo & Máximo & Média & Desvio \\
\hline Altamente insatisfeito & 1 & 0 & 1 & 5 & 0 & 0 \\
\hline Insatisfeito & 2 & 0 & 1 & 5 & 0 & 0 \\
\hline Nem satisfeito nem insatisfeito & 3 & 0 & 1 & 5 & 0 & 0 \\
\hline Satisfeito & 4 & 0 & 1 & 5 & 2,50 & 0,5 \\
\hline Altamente satisfeito & 5 & 32 & 1 & 5 & 5 & 0 \\
\hline
\end{tabular}

Tabela 02 - Estatística por socre - média do grau de satisfação com o trabalho em grupo

Um dos fatores mais importantes que regulam a colaboração é a teoria de aprendizagem na qual a interação cooperativa será baseada. Há mediação também com o recurso tecnológico quando este é tratado pelo educador na sua ação didática. Estas questões foram evidenciadas pelos resultados das figuras 15,16 e 17 e tabelas 01 , 02 e 03 na afirmação de satisfação em score com o trabalho colaborativo, autoria e aprendizagem na disciplina, o se pode inferir pelas novas incursões da prática pedagógica docente. 


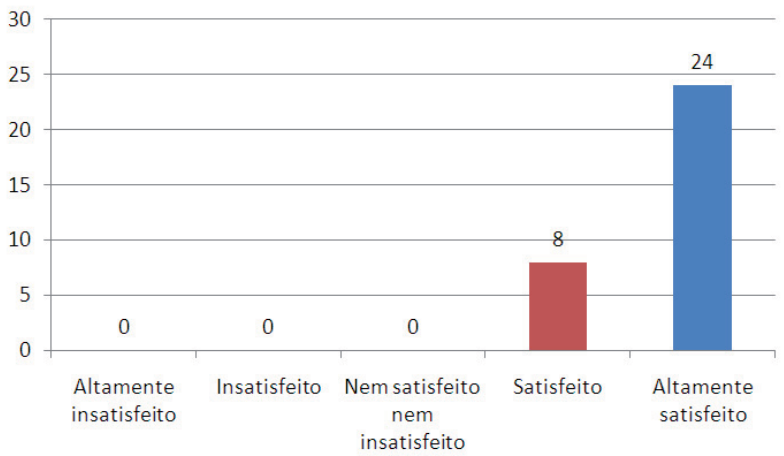

Figura 17 - Nível de satisfação com aprendizagem em Biologia

\begin{tabular}{c|c|c|c|c|c|c}
\hline & & Número & Mínimo & Máximo & Média & Desvio \\
\hline Altamente insatisfeito & 1 & 0 & 1 & 5 & 0 & 0 \\
\hline Insatisfeito & 2 & 0 & 1 & 5 & 0 & 0 \\
\hline Nem satisfeito nem insatisfeito & 3 & 0 & 1 & 5 & 0 & 0 \\
\hline Satisfeito & 4 & 8 & 1 & 5 & 1 & 0,25 \\
\hline Altamente satisfeito & 5 & 24 & 1 & 5 & 3,75 & 1,25 \\
\hline
\end{tabular}

Tabela 03 - Descrição Estatística por score - satisfação com a aprendizagem em Biologia

É possível perceber que o envolvimento dos alunos desencadeia motivação, dinamismo assim como a assimilação dos conteúdos. Como se posiciona Lévy (1993) a multimídia interativa, favorece uma atitude exploratória, até mesma lúdica, face ao material a ser assimilado. É um instrumento bem adaptado a uma pedagogia ativa.

Esta riqueza de achados permite reforçar através de Silva (2003) que o professor que busca interatividade com seus alunos propõe o conhecimento, não o transmite. Em sala de aula é mais 
que instrutor, treinador, parceiro, conselheiro, guia, facilitador, colaborador. É formulador de problemas, provocador de situações, arquitetos de percursos.

\section{Implicações e limitações}

A intervenção pedagógica foi para os respondentes professora e alunos do $1^{\circ}$ ano do ensino médio uma oportunidade de vivenciarem uma relação de aprendizagem ativa, que gerou aprendizado tanto do aplicativo, da disciplina como aprendizagem de situações didáticas que envolveram alunos em trabalho colaborativo e motivacional na revisão dos conteúdos de Biologia.

A contribuição deste estudo sinaliza desafios à formação docente no tocante aos impactos que os avanços tecnológicos projetam na prática pedagógica e na educação, como também ao apontar um lugar para a multimídia e o vídeo digital, como ação motivadora favorável ao processo de aprendizagem dos alunos em disciplinas escolares.

O suporte computacional oferecido para a atividade e a orientação docente, conjugadas ao ambiente com artefatos culturais e o lugar para o aluno ser um participante ativo, favorece as experiências colaborativas nos grupos e de motivação para realizar o empreendimento de aprendizagem: Vídeos digitais.

Como um indicativo de resposta do estudo aponta-se que os dados revelaram índices significativos de satisfação e motivação com a presença de uma prática voltada para a aprendizagem com multimídia. Evidenciando que a construção de vídeo digital com os conteúdos de Biologia deram esse suporte ao ser empregado para tratar da aprendizagem de conceitos, solução de problemas e o desenvolvimento do projeto do vídeo em grupos, possibilitando 
desenvolver ações de aprendizagem colaborativa, no tocante a pesquisa, a seleção de imagens, sons, escolhas e a própria autoria.

Os softwares e os computadores desenvolvidos permitem que sejam calculadas e simuladas cenas - imagens e sons sintéticas cada vez mais realistas. Sem dúvida, estes avanços interessam à pesquisa educacional e propõem um quadro pedagógico para as tecnologias digitais na sala de aula e prática docente

Finalmente, evidencia-se pelos dados apresentados, que os alunos estão participando da sociedade digital, sendo necessário que seus docentes estejam à frente dos desdobramentos dessa cultura para melhor contribuir com a aprendizagem ativa de seus alunos.

O desafio está na mudança de concepção que diz respeito às aprendizagens, não somente das tecnologias, mas do que ensinar, trata-se de fazer aprender.

\section{Referências}

ALARCÃO, I. Professores reflexivos em uma escola reflexiva. 2 . ed. São Paulo: Cortez, 2003.

D’AVILA, C. M. Pedagogia cooperativa e EAD: uma aliança Possível. Educação e contemporaneidade, Salvador, v. 12, n. 20, p. 273-285, jul./dez., 2003.

CARREIRA, J. S. O papel do conhecimento prévio na compreensão em leitura: estratégias de activação e desenvolvimento. 2000. Dissertação (Mestrado) - Universidade de Aveiro Aveiro, 2000. [Documento policopiado - não publicado].

FREIRE, P. A educação na cidade. São Paulo: Cortez, 1991. 
Pedagogia da autonomia: saberes necessários à prática docente. São Paulo: Paz e Terra, 1996.

GONÇALVES, M.L. Para uma aprendizagem significativa: a gestão personalizada do currículo ou a gestão de eu-afectivo. 2002.Tese (Mestrado) - Universidade de Aveiro, Aveiro, 2002. [documento policopiado - não publicado].

LÜDKE, M.; ANDRÉ, Marli E. D. A. Pesquisa em educação: abordagens qualitativas. São Paulo: EPU, 1986.

LÉVY, P. As tecnologias da inteligência: o futuro do pensamento na era da informática. Rio de Janeiro: Editora 34, 1993.

MAYER, R. E.The Cambridge Handbook of Multimedia Learning. 3 ed. Santa Bárbara: Universty of Califórnia, 2005.

. Multimédia Learning: are you asking the right ques-

tions. Educational Psychologis, New York, v. 32, n. 1, p. 1-19, 2001.

MORAN, J. M. O vídeo na sala de aula. Comunicação e educação. São Paulo, v.1, n.2, p. 27-35, Jan./abr. 1995.

. A educação que desejamos: novos desafios e como chegar lá. Campinas, SP: Papirus, 2007.

SILVA, M. Sala de aula interativa. Rio de Janeiro: Quartet, 2000.

.Educação Online. São Paulo: Loyola, 2003.

VEIGA NETO, A. Olhares. In: M. V. Costa. Caminhos investigativos: novos olhares na pesquisa em educação. Porto Alegre: Mediação. p. 19-35.

VIEIRA, F. Autonomia na aprendizagem da Língua Estrangeira. Braga: Universidade do Minho, 1998.

WALKER, R. Editorial. Journal of Education, Cambridge, v.2, n. 34, p.139-142, 2004. 


\title{
Desenvolvimento e avaliação de sistema multimídia para ensino e aprendizado em topografia
}

\author{
Cláudio Silva Soares \\ UEPB - Campina Grande, Paraíba \\ claudio.uepb@yahoo.com.br \\ Tales Anderson Dias Mouzine \\ UEPB - Campina Grande, Paraíba \\ Robson Pequeno \\ UEPB - Campina Grande, Paraíba \\ robson.pequeno@gmail.com
}

\section{Introdução}

A Topografia é uma ciência aplicada, com fundamentos na Geografia e na Trigonometria, que tem por fim representar graficamente, num plano topográfico, os detalhes requeridos de uma parte limitada da superfície da terra, de forma que eles guardem no desenho posições altimétricas e planimétricas relativas às existentes no terreno. A projeção horizontal se chama "planta".

O surgimento das mídias eletrônicas, que divulgam o conhecimento produzido e o acesso à informação que, por sua vez, se 
constituem pilares da educação ocidental moderna, acontecem de forma cada vez mais ágil e, com isto, os critérios de perenidade e permanência dos conhecimentos acumulados se somam ao critério de atualidade (CARVALHO, BOTELHO, 2000).

De acordo com Moreira (1986), o processo de informatização da educação deve ser considerado como meio de ampliação das funções do professor, favorecendo mudanças nas condições e no processo ensino-aprendizagem. A modernização das técnicas de ensino, no entanto, só logrará êxito se usada de forma crítica pelos usuários, de modo geral, visto que deverá estar associada a cada realidade educativa e fundamentada em princípios psicopedagógicos que explicitem certa concepção de ensino e aprendizagem. Em termos pedagógicos, pode-se afirmar que a didática de mídia ainda segue muitos conceitos da tecnologia instrucional tradicional, visto se basear em psicologia comportamentalista (behaviorista), cujos passos básicos são: a análise da tarefa; o avanço em pequenos e progressivos passos de aprendizagem; a participação ativa do estudante; a velocidade de aprendizagem individual e a realimentação imediata do esforço.

O software educacional pode ser visto tanto como uma construção técnica como recurso pedagógico. Do ponto de vista técnico, compreende a parte computacional e é avaliado em termos de sua organização lógica e desempenho. Quanto ao fato de ser um recurso pedagógico, a principal questão corresponde à contribuição do software para o ensino e aprendizagem do seu público alvo (FOCKING, 2001).

Segundo Brandão (1998), o conhecimento das características que tornam o software adequado ou não ao processo ensinoaprendizagem, das modalidades de interação que estabelece com o usuário e de sua inter-relação com os objetivos educacionais em específicas situações de ensino, é de fundamental importância para o êxito da relação entre informática e educação. 
Para Oliveira (1998, apud FOCKING 2001), o software educacional é um programa de computador que possui uma proposta de ensino, com um objetivo educacional predefinido, que se propõe a auxiliar na aprendizagem de conteúdos e habilidades, mediante a utilização de uma interface computadorizada. O software deve possuir recursos que auxiliem no processo de aquisição de determinado conhecimento, promovendo situações estimulantes para o aluno, não apenas despertando a sua atenção, mas mantendo-a ao longo de sua interação. Para que este propósito seja atingido, os conteúdos pedagógicos apresentados no software educacional devem ser claros, consistentes, compreensíveis. Recursos multimídia e recursos motivacionais devem provocar o interesse pelo assunto ao mesmo tempo em que facilitam a relação ensino/ aprendizagem.

Há, portanto, o consenso de que o software educacional deve atender aos objetivos específicos e fazer uso de recursos que potencializem o processo não só de aquisição, mas também, de reforço de determinados conhecimentos e habilidades, estimulando o desenvolvimento cognitivo do usuário, permitindo um aprendizado expressivo.

Neste sentido, o objetivo deste trabalho foi desenvolver e avaliar um software educacional sobre topografia, com recursos multimídia, destinado ao meio acadêmico das ciências agrárias.

\section{Material e métodos}

O presente trabalho foi constituído a partir de uma equipe multidisciplinar, por profissionais das áreas de engenharia agrícola e ciência da computação. A estrutura do curso básico de topografia foi programada de tal maneira que o usuário possa acessar livremente as diferentes unidades do CD-ROM, usando 
a estrutura hipermídia, de forma seqüenciada. O desenvolvimento do software foi constituído das seguintes etapas: a) Planejamento - Onde foi delineado o objetivo principal do projeto, definidos e organizados os conteúdos, assim como seus tópicos e sub-tópicos. O tópico escolhido, dentro da disciplina Topografia, foi a Planimetria. Também foram escolhidos os tipos de mídias que deveriam constar no curso de acordo com o tópico abordado, e também foi definido o público alvo ao qual interessaria o sistema multimídia. b) Interação - Fase em que foi discutida a estrutura do CD-ROM, em termos de conteúdo e de distribuição dos tópicos e sub-tópicos. c) Instanciação - Corresponde à parte operacional do software e aos conceitos de hipermídia, onde foram criados os mapas de informação para apresentação do conteúdo. Esta etapa foi usada para se definir as navegações e estruturas de acesso nas entidades e blocos de informações. d) Story Board e Script Book - A confecção dos Story Boards e Script Books consistiu na elaboração das informações visuais e dos comandos mostrados em cada tela. e) Projeto da Interface - Esta etapa foi de responsabilidade do programador visual que, de posse das informações coletadas na fase de interação e com os Story Boards e Scripts Books em mãos, passou a dar forma a cada tela do CD-ROM. f) Escolha das Mídias -Esta etapa foi desenvolvida logo após a elaboração dos Story Boards e Script Books, paralelamente à etapa de interface. g) Autoria - Consistiu em implementar o projeto numa linguagem computacional com recursos hipermídia. A ferramenta utilizada neste projeto foi o Flash MX. Sua escolha deveu-se à facilidade de uso e aos vários recursos de mídias. h) Validação - Após a implementação pela autoria obteve-se um protótipo do CD-ROM para fazer uma avaliação técnica. A etapa de validação do CD-ROM foi a última fase em que foram permitidas alterações de conteúdo, podendo acarretar mudanças nas fases anteriores. i) Teste Terminada a aplicação, foram feitas as avaliações necessárias para validação do produto. Após os testes, o software ficou pronto para reprodução e comercialização. 
$\mathrm{Na}$ determinação deste universo amostral para avaliar a usabilidade do software proposto foram escolhidos participantes com perfis afins, ou seja, alunos que já tinham sidos aprovados na disciplina de Topografia em semestres anteriores e professores que possuíam conhecimentos nesta área, o que possibilitou a discriminação das três categorias de usuários de teste necessárias - estudantes de nível médio do curso Técnico em Agropecuária, estudantes de graduação do curso de Licenciatura em Ciências Agrárias e, professores destes cursos, ambos da Universidade Estadual da Paraíba, Campus IV, em Catolé do Rocha-PB.

Para avaliação do sistema multimídia foram distribuídas cópias do CD-ROM a estes participantes, quando foi solicitado que cada participante da pesquisa, 47 pessoas envolvidas, avaliasse o CD-ROM como um todo, sob diferentes aspectos, para que se pudesse responder às fichas de avaliação. Essas fichas constaram de questionários aplicados com a finalidade de avaliar a função educacional do sistema multimídia na disciplina de topografia.

Os resultados obtidos foram separados por grupo avaliado: Grupo A (estudantes de nível técnico), Grupo B (estudantes de nível superior) e Grupo C (professores da área de Ciências Agrárias), sendo os dados agrupados por categoria avaliada: interface, conteúdo e interatividade.

Do modelo das fichas de avaliação adotadas na pesquisa, foi aplicada uma escala de Likert de cinco pontos, sendo a resposta de cada questão representada da seguinte maneira: péssimo $=1$; ruim $=2$; regular $=3$; bom $=4$ e excelente $=5$. Para análise geral dos dois grupos de alunos (técnico e superior), foram utilizadas as notas atribuídas a cada resposta da escala de Likert, citada no parágrafo anterior, em que as mesmas variaram de 1 a 5 . A partir dessas notas foi determinada a média dos pontos, conforme 
metodologia descrita por Berenson e Levine (1992), da qual foi adaptada para a seguinte fórmula:

$$
\mathbf{M P}=\frac{(P 1 \cdot N a)+(P 1 \cdot N a)+(P 1 \cdot N a)+(P 1 \cdot N a)+(P 1 \cdot N a)}{N T a}
$$

Onde: $\mathrm{MP}=$ Média dos pontos; $P 1, P 2, P 3, P 4$ e P5= Pontos referentes às notas atribuídas às respostas da escala de Likert, , ou seja, 1, 2, 3, 4 e 5, respectivamente; $N a=$ Número de alunos que atribuíram cada ponto individualmente da escala de Likert e, $N T a=$ Número total de alunos envolvidos na pesquisa.

\section{Resultados e discussão}

\section{Apresentação das principais telas do software}

O software elaborado neste trabalho foi denominado "Guia Prático para Levantamento Planimétrico", sendo executável e desenvolvido em ambiente Windows, porém pode ser executável em outros ambientes que possuam o Macromedia Flash Player. O curso do CD-ROM possui uma interface simples e apresenta o conteúdo em páginas seqüenciais. A tela principal é ilustrada na Figura 1. 


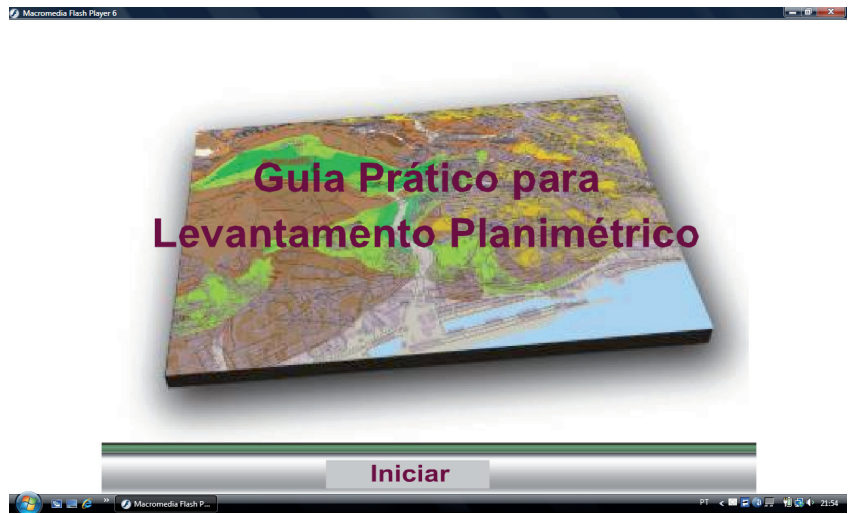

Figura 1 - Acesso inicial às telas do CD-ROM.

Após iniciar o software, nas próximas páginas há uma introdução sobre a Topografia e suas divisões. Nessa fase o software aborda alguns conceitos relacionados às grandezas medidas num levantamento topográfico como ângulos horizontais e verticais. Além das explicações na forma de texto, essas grandezas foram ilustradas com animações como mostram as figuras 2 e 3 a seguir.

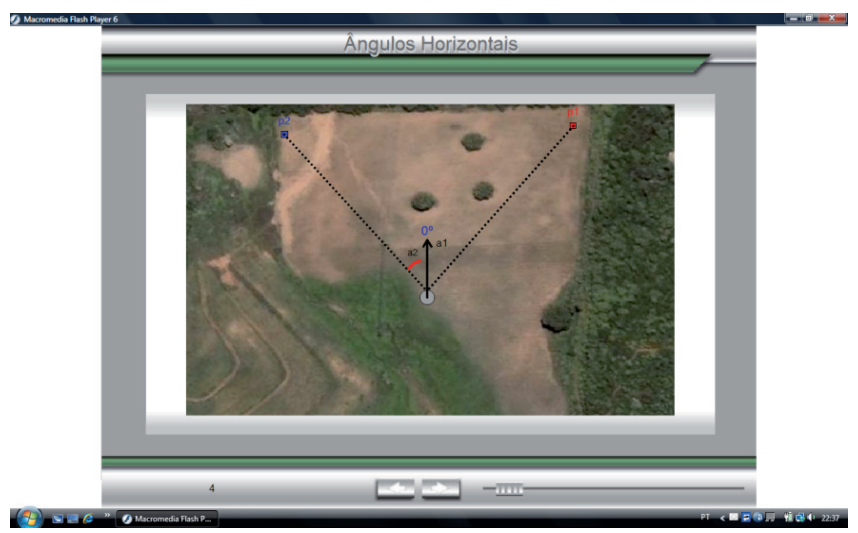

Figura 2 - Animação e demonstração em flash dos ângulos verticais. 


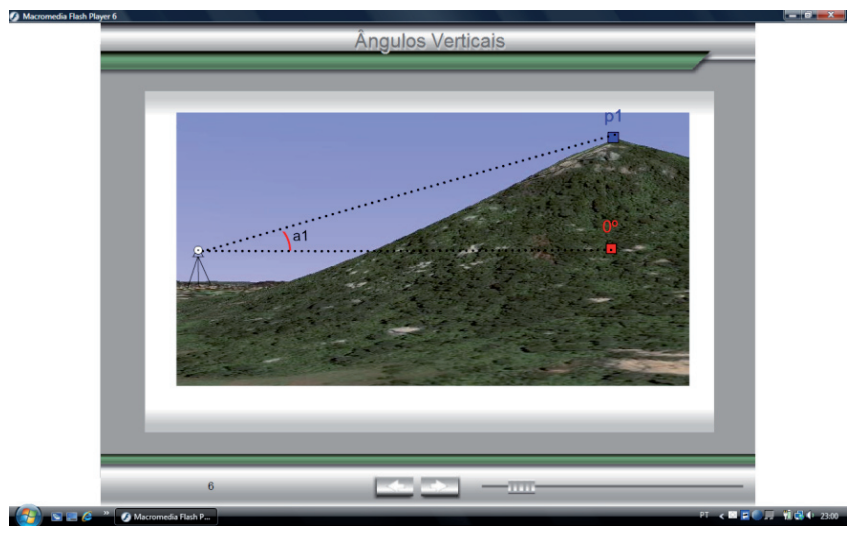

Figura 3 - Animação e demonstração em flash dos ângulos horizontais.

Nas próximas telas, através de textos, foram explanados os conceitos referentes à medida direta de distância, onde estão inseridas as grandezas lineares como distâncias horizontais, verticais e inclinadas. Em seguida, esses conceitos foram reforçados com animações gráficas mostrando cada uma dessas grandezas (Figura 4).

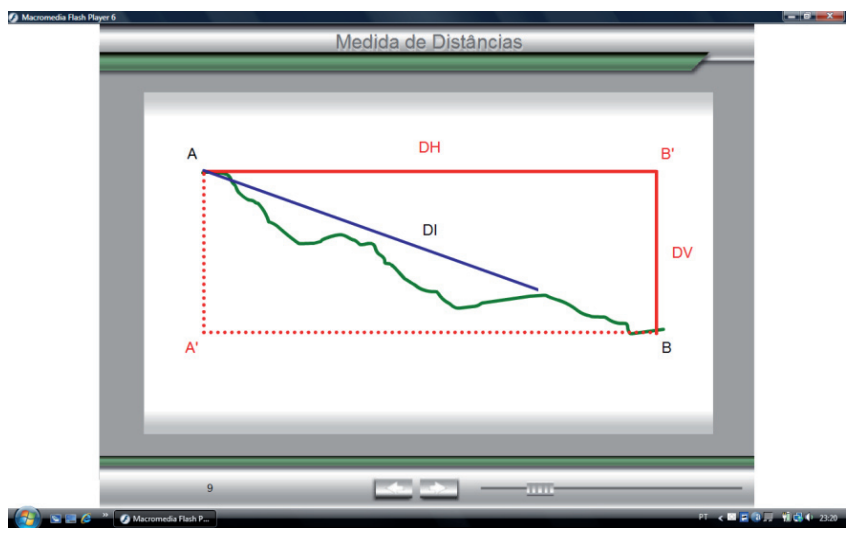

Figura 4 - Animação e demonstração das distâncias horizontais, verticais e inclinadas. 
Ainda no tópico medida direta de distância, foram demonstrados os dispositivos utilizados para determinação dessas grandezas (Figura 5). Também foram demonstrados os dois métodos de determinação direta dessas distâncias (Figura 6 e 7), enfatizando sempre as maneiras corretas de aplicação no campo. Essas animações são bastante importantes do ponto de vista prático, pois representa de maneira muito clara o modo como se procede em um levantamento topográfico.

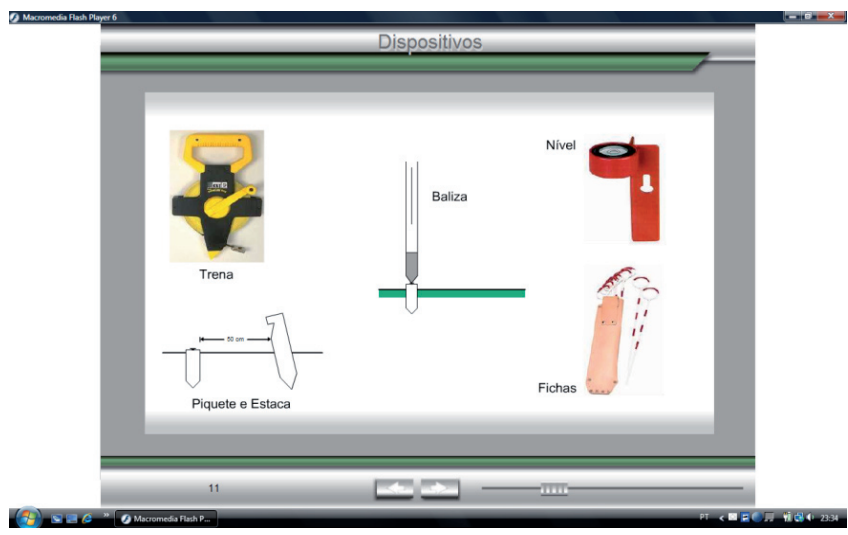

Figura 5 - Dispositivos utilizados na determinação das distâncias.

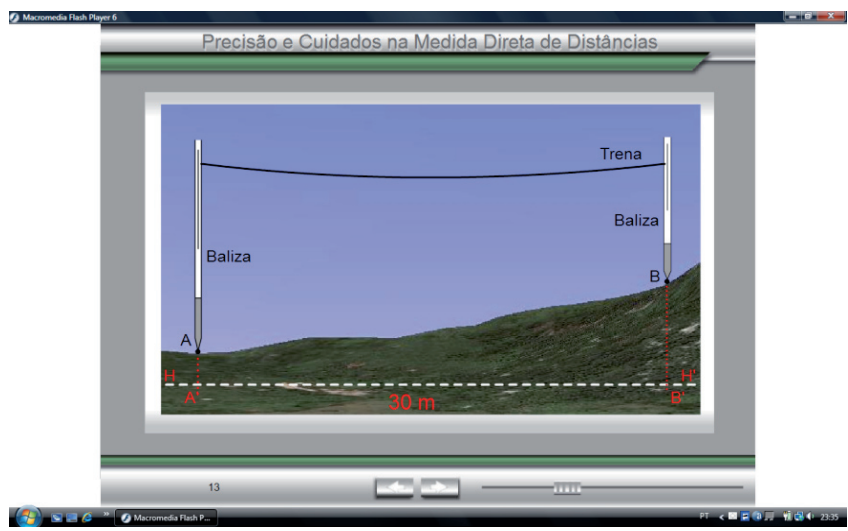

Figura 6 - Determinação direta de distâncias horizontais com lance único. 


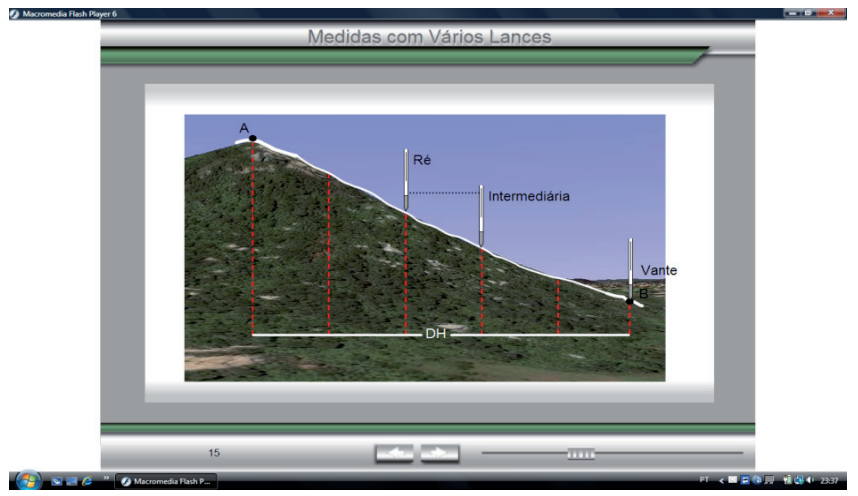

Figura 7 - Determinação direta de distâncias horizontais com vários lances.

No tópico seguinte, foram mostrados os conceitos e as animações referentes às medidas indiretas de distância. Neste segmento foram ilustrados os equipamentos (Figura 8), algumas formas de leitura dos mesmos (Figura 9) e, os métodos dessas medidas indiretas (Figura 10).

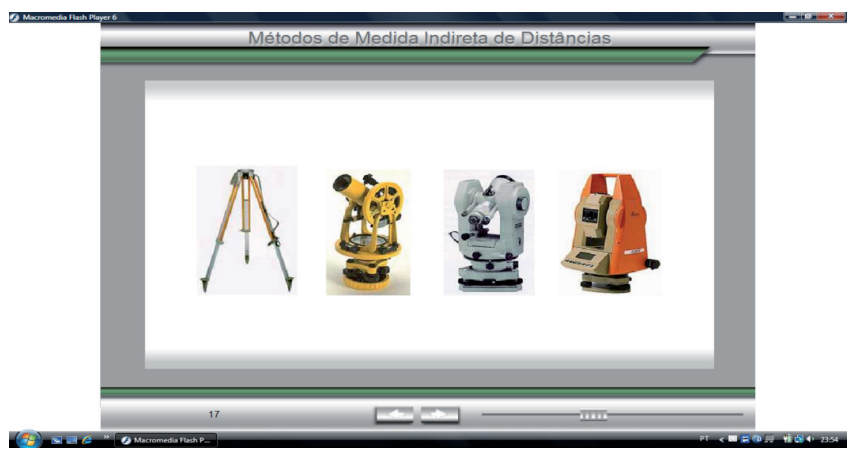

Figura 8 - Equipamentos utilizados na determinação indireta de distância. 


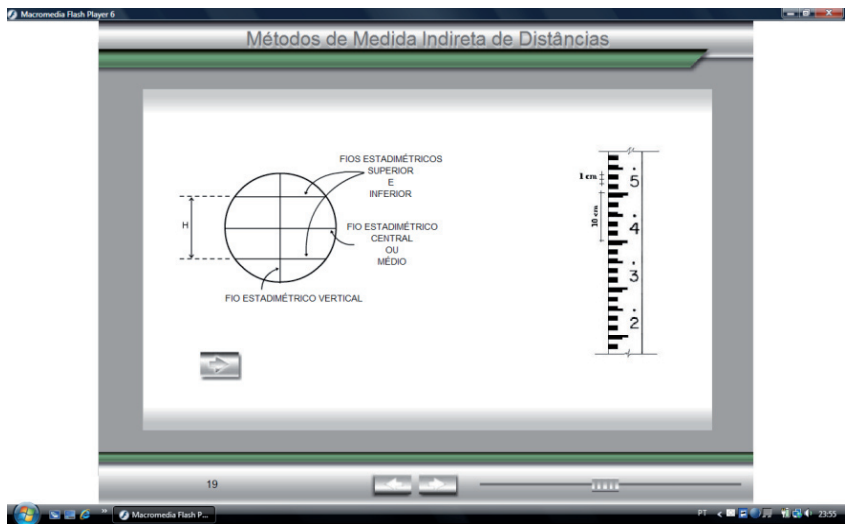

Figura 9 - Animação da leitura da régua para determinação indireta de distância.

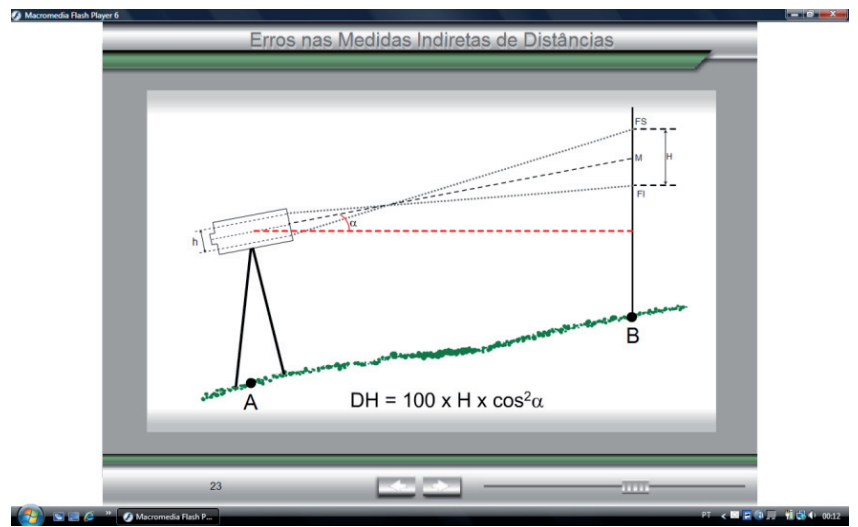

Figura 10 - Leitura dos equipamentos utilizados na determinação indireta de distância. 
Os métodos de levantamento planimétricos foram explicados através de textos, e demonstrados por meio de animações que facilitaram o aprendizado dos alunos na disciplina de topografia (Figuras 11 e 12).

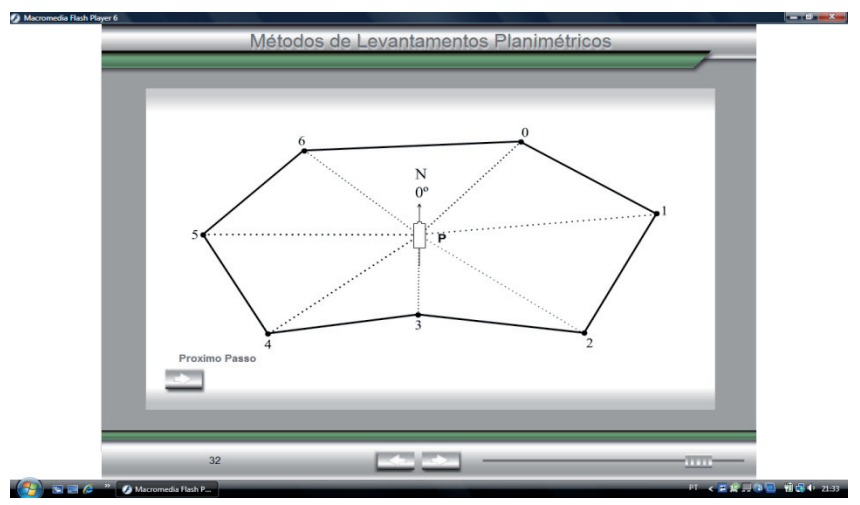

Figura 11 - Demonstração do método de levantamento planimétrico por interseção utilizado na determinação indireta de distância.

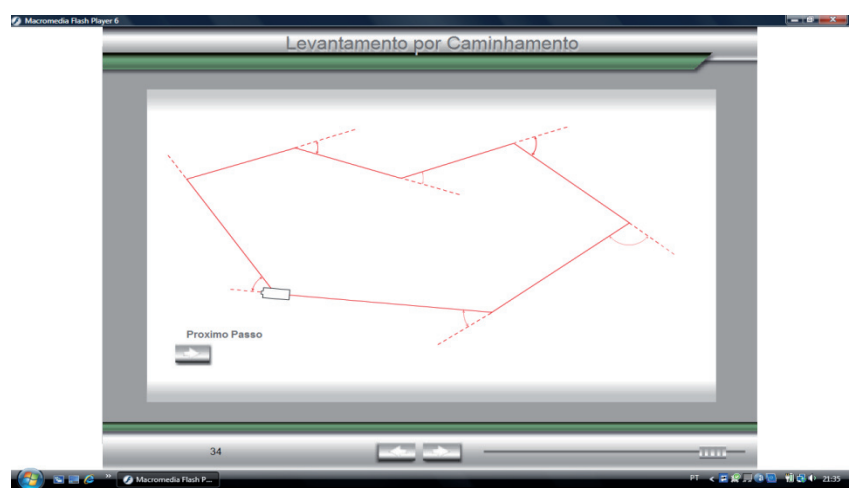

Figura 12 - Método de levantamento planimétrico por caminhamento. 


\section{Resultados provenientes dos apêndices}

Os resultados referentes às respostas do questionário, aplicado aos alunos e professores, estão dispostos nas figuras 13 a 22, sendo discutidos logo abaixo.

A facilidade de acesso e uso das telas do CD-ROM foi avaliada pelos alunos e professores e apresenta seus resultados na Figura 13. Verifica-se, portanto, que as respostas foram semelhantes entre alunos do curso técnico e superior, pois a maioria classificou essa característica entre boa e excelente. Quando avaliado por professores, a facilidade e uso das telas se mostraram de forma excelente para todos esses avaliadores (100\%). Quando calculada a média dos pontos dos dois grupos de alunos (tecnolandos e graduandos), obteve-se uma nota 4,5 na escala de Likert para essa característica avaliada. Dessa forma, o CD-ROM cumpriu o objetivo de permitir ao usuário um manuseio de suas telas de forma simples, rápida e eficiente.

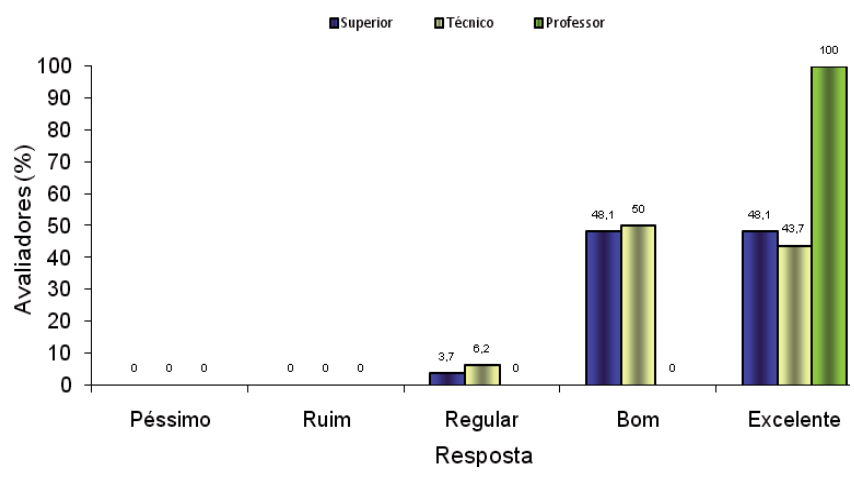

Figura 13 - Avaliação da facilidade de acesso e uso das telas do CD-ROM.

Resultados semelhantes também foram obtidos por ZemMascarenhas e Cassiani (2001) quando avaliaram um software educacional para ensino de enfermagem pediátrica, pois os mesmos 
verificaram que a qualidade da interface de seu programa foi considerada excelente pela maioria dos avaliadores $(80,27 \%)$.

Com relação à sequência dos tópicos distribuídos no CD-ROM (Figura 14), observa-se que os alunos do curso superior classificaram essa característica como excelente $(59,3 \%)$ e boa $(40,7 \%)$. Já a maioria dos professores (75\%) concordam que esse parâmetro foi de excelente qualidade. Os alunos do curso técnico, em sua maioria $(62,5 \%)$, classificaram essa característica como boa. Na média dos grupos de alunos, essa avaliação apresentou 4,3 pontos, o que significa que a sequência dos tópicos apresentou qualidade entre bom e excelente.

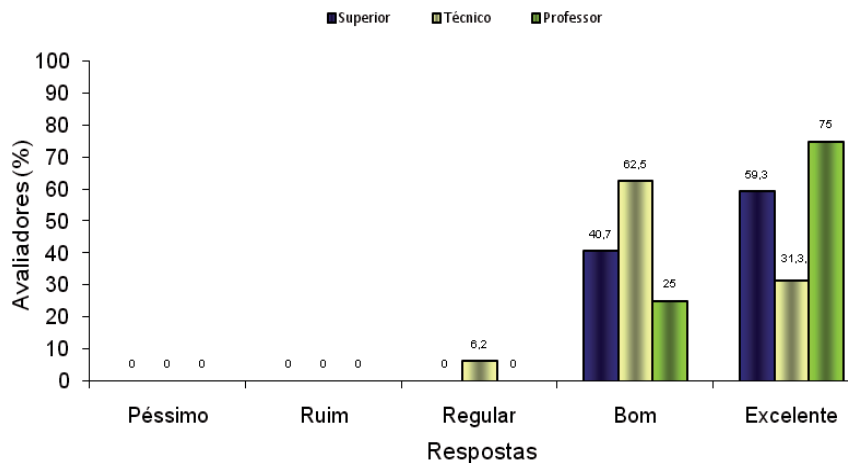

Figura 14 - Avaliação da seqüência dos tópicos do CD-ROM.

Vale salientar que a seqüência lógica de um determinado assunto, seja ela distribuída em livros, apostilas ou CD-ROM, deve ser a mais simples e eficiente o possível, pois dela depende muitas vezes o sucesso do aprendizado. Neste contexto, Dittz (2004) comenta que a carga informativa de um $C D$-ROM ou de uma página multimídia recorre a diversos sentidos ao mesmo tempo, tornando-a significativamente mais completa se comparada a um texto comum com imagens estáticas, oferecendo assim um maior poder de assimilação e retenção. 
Os recursos de multimídia também foram utilizados para o ensino de estruturas de concreto armado e protendido por Assis (2002). Esse autor verificou que $60 \%$ dos avaliadores desse tipo de recurso didático lhe atribuíram uma boa apresentação, quanto à disposição de seu conteúdo, corroborando com os resultados encontrados neste trabalho com a disciplina de topografia.

$\mathrm{Na}$ Figura 15 é destacada a avaliação da quantidade de informações contidas no CD-ROM. Nesta avaliação, tanto os alunos graduandos $(51,8 \%)$ e tecnolandos $(68,7 \%)$ quanto os professores (75\%), em sua maioria, qualificaram esta característica como de boa qualidade. Os alunos atribuíram, em média, uma nota de 4,2 pontos para a avaliação da quantidade de informações do CD-ROM.

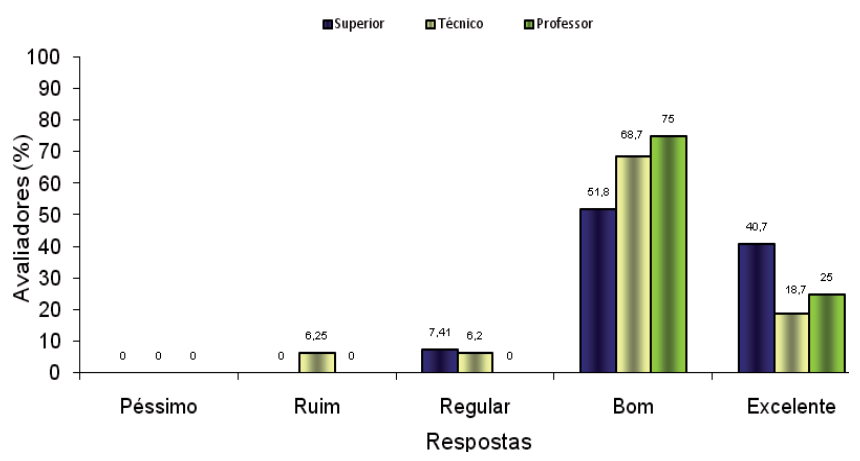

Figura 15 - Avaliação da quantidade de informações do CD-ROM.

$\mathrm{Na}$ avaliação de um sistema multimídia para ensino e aprendizado de irrigação, Oliveira et al (2002) também verificaram respostas positivas quando a quantidade de informações de seu CD-ROM foi julgado por produtores rurais e alunos de nível médio e superior, ligados às ciências agrárias. Os autores verificaram uma média de 6,8 pontos de um total de 09 pontos para essa característica avaliada. 
A qualidade das fotos digitais (Figura 16) foi excelente, segundo a avaliação da maioria dos alunos de graduação (74\%) e nível técnico $(68,7 \%)$, e por todos os professores (100\%). A média dos pontos, atribuída pelos alunos, ficou em 4,7 pontos para a qualidade das fotos utilizadas nas animações, mostrando que as mesmas atenderam ás expectativas desses avaliadores.

Resultados semelhantes também foram obtidos por ZemMascarenhas e Cassiani (2001) e por Oliveira et al (2002) quando submeteram essa característica de seus produtos multimídias ao julgamento de avaliadores externos.

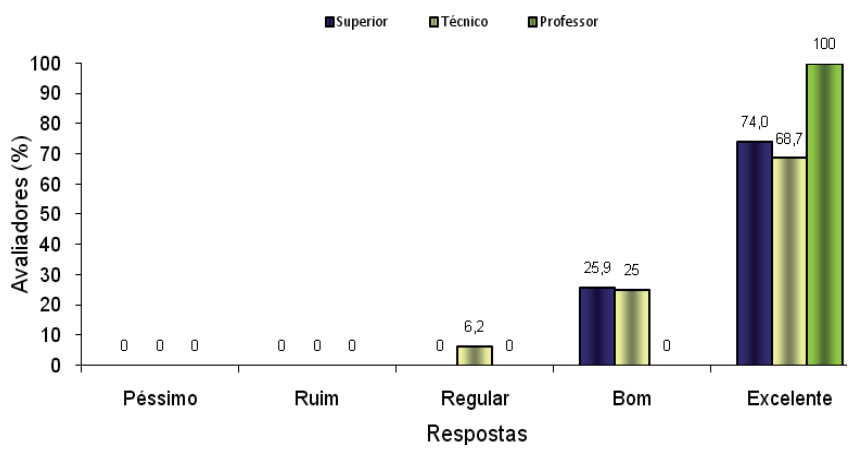

Figura 16 - Avaliação da qualidade das fotos digitais do CD-ROM.

Quanto ao tamanho e tipo das fontes utilizadas no CD-ROM, verifica-se que a maioria dos alunos (tecnolandos e graduandos) classificou esse parâmetro como bom (Figura 17). Já os professores dividiram sua opinião pela metade, indicando esse parâmetro como bom e excelente. De modo geral para os alunos, a média atribuída a essa característica foi de 4,1 pontos, segundo a escala de Likert utilizada.

O tamanho e tipo das fontes são extremamente importantes nesse tipo de instrumento, pois delas depende a facilidade ou 
dificuldade de leitura e aprendizado do aluno. Dessa forma, deve-se tornar o aplicativo o mais agradável possível para se obter um melhor aprendizado e interação homem-máquina.

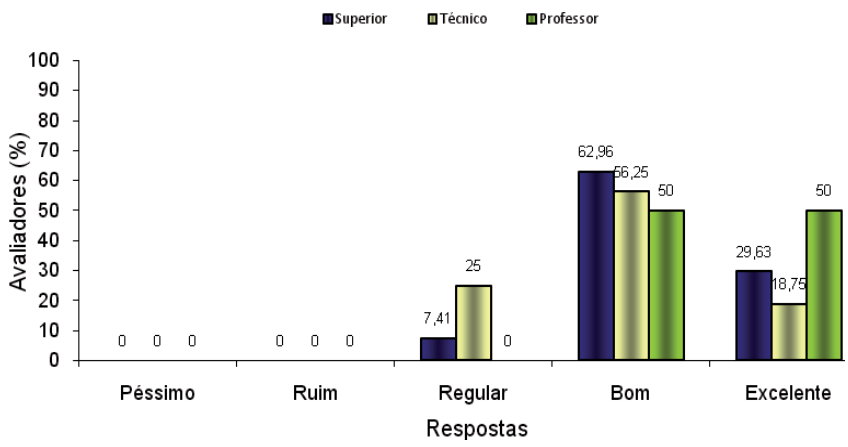

Figura 17 - Avaliação do tamanho e tipo das fontes utilizadas no CD-ROM.

O CD-ROM mostrou bom feedback para $75 \%$ dos alunos do curso técnico e, excelente para $51,85 \%$ e $75 \%$ dos graduandos e professores, respectivamente (Figura 18). Observou-se ainda que a média atribuída pelos dois grupos de alunos também foi bastante satisfatória quando os mesmos avaliaram esse feedback (4,3 pontos).

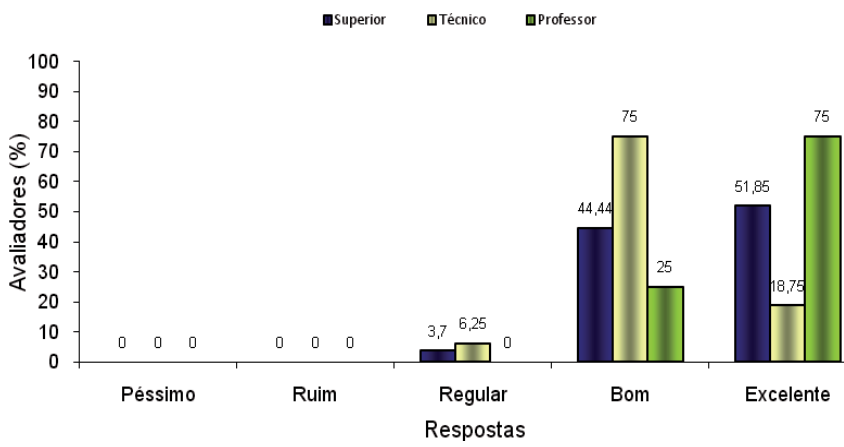

Figura 18 - Avaliação do o feed-back do CD-ROM. 
A multimídia permite que softwares sejam criados um pouco mais próximos à interface humana, possibilitando que mensagens sejam transmitidas de modo mais claro e menos cansativo que os tradicionais livros e revistas (RIBEIRO et al., 2001). Dessa forma, quanto maior a interação entre homem e máquina, no processo de ensino-aprendizagem, mais eficiente será o software utilizado pelo professor ou aluno.

A qualidade das animações gráficas foi classificada como excelente por $59,26 \%$ dos alunos de graduação e por $75 \%$ dos professores. Por outro lado, a metade dos alunos do curso técnico expressou que essa qualidade era boa, enquanto que a outra metade indicou que a mesma era excelente (Figura 19). Em média, os alunos atribuíram 4,5 pontos a qualidade das animações contidas no CD-ROM proposto.

Essa interface do produto multimídia é o conjunto dos elementos gráficos e do sistema de navegação. Muitos títulos multimídia de conteúdo vasto e aprofundado naufragam por oferecer interface de baixa qualidade, pois figuras pobres podem aborrecer o usuário pela falta de apelo visual (ASSIS, 2002).

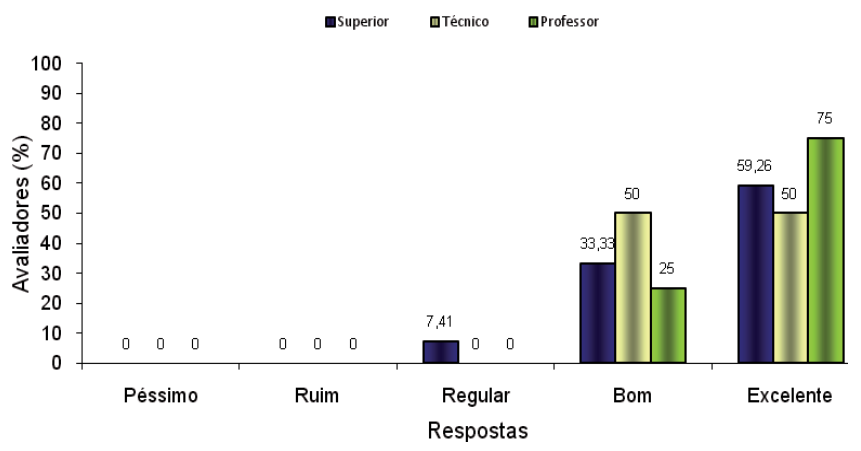

Figura 19 - Avaliação da qualidade das animações gráficas do CD-ROM. 
Para a maioria dos tecnolandos $(56,25 \%)$ e professores $(75 \%)$, foi excelente a eficiência dos textos para compreensão dos conceitos de topografia, porém a maioria dos graduandos $(66,67 \%)$ opinou que essa característica do CD-ROM era boa (Figura 20). Em termos de nota, esse atributo alcançou 4,4 pontos na escala de Likert, segundo média obtida através dos dois grupos de alunos.

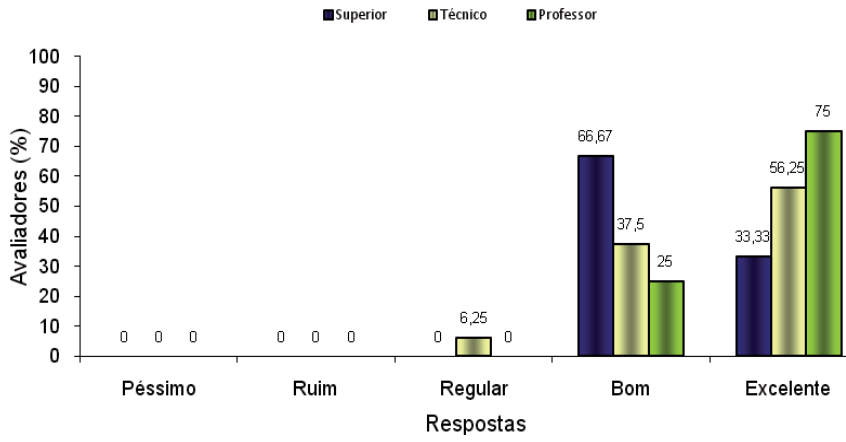

Figura 20 - Avaliação da eficiência dos textos escritos no CD-ROM para compreensão dos conceitos de topografia.

Segundo Assis (2002), a informação multimídia, mesmo sendo de natureza essencialmente eletrônica, dificilmente teria sucesso se não fosse o intenso uso do texto. Para esse autor, embora a informação sonora e videográfica façam parte do composto multimídia, o texto ainda possui uma localização fundamental neste tipo de produto. Desse modo, a multimídia pode trazer de volta a ênfase à informação escrita numa sociedade que progressivamente lê cada vez menos.

Na Figura 21, estão expressas as expectativas dos avaliadores do CD-ROM, em termos teóricos. Observa-se que os professores foram unânimes ao afirmarem uma excelente expectativa, sendo que $50 \%$ dos tecnolandos também apresentaram esta mesma opinião. Quanto aos graduandos, 66,6\% dos mesmos afirmaram uma 
boa expectativa, em termos teóricos. Em termos teóricos, foi verificada uma média de 4,3 pontos na escala utilizada.

A disciplina de topografia é, em sua maioria, lecionada de forma prática. No entanto, é preciso que o estudante tenha uma boa base teórica para aplicar seus conhecimentos quando se deparar com as aplicabilidades em campo.

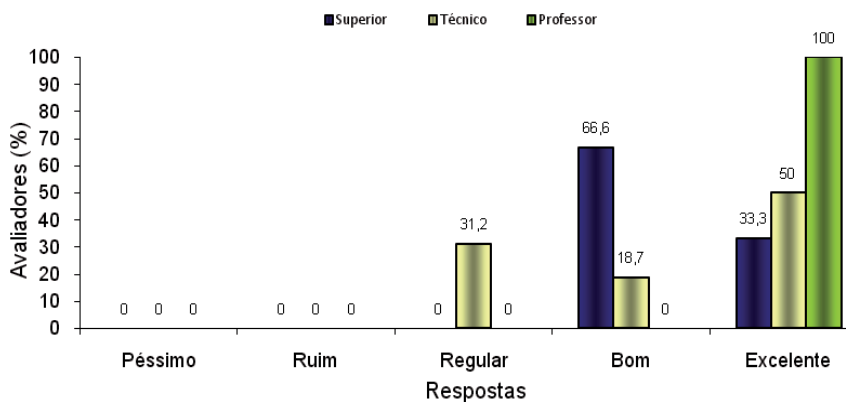

Figura 21 - Avaliação, em termos teóricos, do CD-ROM em relação às expectativas do usuário.

Em termos práticos, as expectativas do CD-ROM foram excelentes para os professores, em sua totalidade (100\%), e para tecnolandos, em sua maioria (75\%). Para os graduandos (55,5\%), essa expectativa foi considerada como boa (Figura 22). Na escala de Likert, para essa qualidade, a média dos pontos dos alunos ficou em 4,3 , o que confirma a boa aceitabilidade do produto por esses avaliadores. 


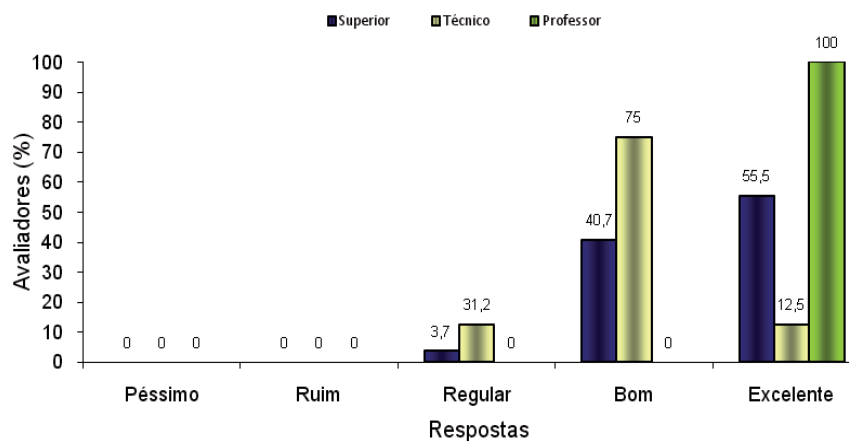

Figura 22 - Avaliação, em termos práticos, do CD-ROM em relação às expectativas do usuário.

\section{Considerações finais}

O sistema multimídia avaliado pode ser utilizado como recurso didático no ensino e aprendizado de planimetria, de maneira satisfatória, segundo avaliação de estudantes e professores da área de ciências agrárias.

O uso de material multimídia nas Ciências Agrárias tem trazido benefícios a vários alunos, ao motivá-los e ajudá-los a visualizar várias situações teóricas consideradas importantes para a formação de um bom profissional.

Os alunos demonstraram interesse neste tipo de material didático, expressando também a necessidade de ampliação de trabalhos desse tipo para os demais conceitos aplicados em topografia, assim como para as demais disciplinas do curso de licenciatura em ciências agrárias.

A utilização desse tipo de recurso computacional como ferramenta de auxílio no processo ensino-aprendizagem e a 
implementação deste instrumento no ambiente educacional vem se confirmando não somente nas universidades, mas também nos outros segmentos educacionais, como no ensino primário, secundário e até mesmo na pós-graduação. No entanto, a maioria dos docentes e alunos ainda apresenta certa resistência quanto à utilização desses recursos, uma vez que, para poder utilizá-los, são necessários alguns conhecimentos básicos sobre informática.

\section{Referências}

ASSIS, W. S. Utilização de recursos multimídia no ensino de concreto armado e protendido. 2002. 121 f. Dissertação (Mestrado em Engenharia). Escola Politécnica da Universidade de São Paulo, São Paulo, 2002.

BERENSON, M. L.; LEVINE, D. M. Basic business statistics: concepts and applitions. New Jersey: Prentice Hall, 1992.

BRANDÃO, E. J. R. Repensando modelos de avaliação do software educacional. 1998. Disponível em: <http://www.minerva.uevora.pt/ simposio/comunicacoes/artigo.html>. Acesso em: 18 de janeiro de 2008.

CARVALHO, G. M. G.; BOTELHO, F. V. U. Educação à distância: um estudo sobre expectativas dos alunos em relação ao uso do meio impresso ou eletrônico. 2000. Disponível em: <http://www.intelecto. net/ ead_textos/glaucia1.htm>. Acesso em: 10 Jan. 2008.

DITTZ, C. T. Novas tecnologias de informação e comunicação no ensino-aprendizagem de conforto luminoso em arquitetura e urbanismo. 2004. 200 f. Dissertação (Mestrado em Engenharia Civil). Universidade Estadual de Campinas, Faculdade de Engenharia Civil, Arquitetura e Urbanismo, São Paulo, 2004. 
FOCKING, G. P. Um estudo sobre técnicas de avaliação de software educacional. 2001. Disponível em: <http://www.inf.ufsc.br/ focking/ doc_finalie.html>. Acesso em: 16 Jan. 2008.

MOREIRA, M. O uso de computador na educação: pressupostos psicopedagógicos. Educação em Revista, Belo Horizonte, n.4, p. 13-17, 1986. OLIVEIRA, R. A.; MOTA, R. S.; FARIAS, C. V.; LEACIR, N. B.; RAMOS, M. M. Desenvolvimento e avaliação de sistema multimídia para ensino e aprendizado de irrigação. Revista Brasileira Engenharia Agrícola Ambiental, Campina Grande, v.6, n.3, p. 553-556, 2002.

RIBEIRO, C. A.; PINTO, C. S.; GRAZIANI, M. Y.; KATO, M. Desenvolvendo um sistema de exploração multimídia. 2001. 76 f. Monografia (Especialização em Informática Empresarial), UNESP, Guaratinguetá, 2001.

ZEM-MASCARENHAS, S. H.; CASSIANI, S. H. B. Desenvolvimento e avaliação de um software educacional para o ensino de enfermagem pediátrica. Revista Latino-americana de Enfermagem, v.9, n.6, p. 13-8, 2001. 



\title{
Novas tecnologias e pessoas com deficiências: a informática na construção da sociedade inclusiva?
}

\author{
Ligia Pereira dos Santos \\ UEPB - CEDUC, Campina Grande, Paraíba \\ ligia.ceduc@ig.com.br \\ Robson Pequeno \\ UEPB - CCT Campina Grande, Paraíba \\ robson.pequeno@gmail.com
}

\section{Introduç̃̃o}

O debate sobre Inclusão Social tem sido destaque no final do século XX e início do século XXI onde presenciamos uma revolução científico-tecnológica, um mundo globalizado e interconectado por redes digitais, onde vivemos "mergulhados" num turbilhão de informações, que invadem nosso cotidiano.

Inicia-se o novo milênio com sérios desafios que exigem o repensar e o recriar desse modelo civilizatório. Não obstante, algumas relevantes conquistas ocorreram no campo dos direitos humanos e na formação de um novo paradigma, que traz a consciência ao ser humano e diz respeito a todos e todas - somos um só corpo social integrado e intrinsecamente interdependente por cabos e fios cibernéticos. 
Tem sido notório que jornais, seminários acadêmicos, telenovelas, planejamento nas escolas, cursos de formação continuada estatais e municipais, debates científicos e na rede mundial de computadores questões que norteiam a Inclusão da Pessoa com Deficiência na sociedade. Tais conquistas representam frutos da luta de grupos de pessoas com deficiência como também de suas famílias e pesquisadores que, no decorrer da história das sociedades, não usufruíam de tamanha abertura ao convívio social.

Neste sentido, esta pesquisa investigou o micro espaço do direito à liberdade, contra a discriminação e luta pela inclusão social, apresentando as novas tecnologias da educação como um instrumento da inclusão social da pessoa com deficiência.

Pressupomos que a educação, tendo como suporte as tecnologias, é, na verdade, um movimento educativo e cultural que busca a completude do ser humano, dentro dos moldes do pensamento equânime, bem diferente do processo de exclusão presente na história da humanidade.

$\mathrm{Na}$ antiguidade (até 476 a.C) as crianças que nasciam com algum tipo de deficiência, eram vistas pela sociedade grega como deformadas. Normalmente eram jogadas em lugares ermos, nos esgotos, posto que, predominava a idéia de que o corpo não perfeito era demoníaco.

No período do Império Romano, as pessoas com deficiência eram sujeitadas a situações de ridicularização e abandono tanto pelos familiares quanto pelo Estado. Comumente eram utilizados como bobos da corte.

$\mathrm{Na}$ Idade Média, as pessoas com deficiência viviam isoladas do resto da sociedade em asilos, conventos e albergues, a exemplo da temática abordada no filme "O corcunda de Notre Dame". Só em 1854, surgiu a criação de duas escolas residenciais para deficientes da audição e da visão denominadas atualmente de Instituto Benjamin Constant e Instituto Nacional de Educação de Surdos. 
A Era da Apatia (1900-1940) foi caracterizada por testes e outros instrumentos científicos de medidas para rotulações e classificação das pessoas com deficiência para determinar o grau da deficiência.

Em 1948, divulga-se a primeira diretriz da nova visão, Declaração Universal dos Direitos Humanos "Todo ser humano tem direito à educação" ficando conhecida como Era da Simpatia.

Por fim, chegamos à Era dos Direitos e Aceitação (1958-1981) quando a Educação Especial no Brasil tem o seu espaço na Lei de Diretrizes e Bases (LDB) A lei 4.024 de 1961, determina que a educação das pessoas com deficiência deva ser incluída no Sistema Geral de Educação.

Declarações e tratados mundiais passam a defender a inclusão em larga escala, e, em 1985, a Assembléia Geral das Nações Unidas lança o Programa de Ação Mundial para as pessoas deficientes recomendando que o ensino das pessoas com deficiência deve acontecer dentro do sistema escolar regular..

No Brasil, a Constituição de 1988, garante no Artigo 208, inciso III: Atendimento educacional especializado aos portadores de deficiência na rede regular de ensino.

Em junho de 1994, dirigentes de mais de oitenta países se reúnem na Espanha e assinam a Declaração de Salamanca. Tal Declaração proclama as escolas regulares inclusivas como o meio mais eficaz de combate à discriminação. A década de 90 é marcada por grandes avanços na área da Educação Especial, que passa a fazer parte integrante do sistema educativo e possui um regulamento próprio denominado Política Nacional de Educação Especial, pautada no Plano Decenal de Educação para Todos.

A lei de Diretrizes e Bases (LDB) nº 9.394/96 se ajusta à legislação Federal e aponta que a educação dos portadores de necessidades especiais deve dar-se preferencialmente na rede regular de ensino. 
Em decorrência da necessidade de construção da sociedade inclusiva, é pertinente lembrarmos que por iniciativa, do Conselho Nacional da Pessoa Portadora de Deficiência- CONADE- aconteceu, no período de 12 a 15 de maio de 2006, na cidade de Brasília, a 1 Conferência Nacional dos Direitos da Pessoa Portadora de Deficiência, com o tema - Acessibilidade: você também tem compromisso conforme publicação no Boletim Informativo do Centro de Apoio Operacional das Promotorias de Justiça de Defesa das Pessoas Portadoras de Deficiência e dos Idosos- CAO PPDI, que comunica: "Na oportunidade, o país estará debatendo os direitos da Pessoa com deficiência, com enfoque na cidadania com liberdade em todas as áreas, e reforçando o compromisso do trabalho, com ênfase na inserção das P.P.D. com cidadania e dignidade" ( I CONFERÊNCIA..., 2006).

Consideramos que nossa pesquisa justificou-se pela importância de construir respostas para as políticas discutidas na Nação e pelo específico empenho da construção da inclusão através da informática.

Compreendemos que as tecnologias de informação abrangem todas as atividades desenvolvidas na sociedade pelos recursos da informática. É a difusão social da informação em larga escala de transmissão, a partir destes sistemas tecnológicos inteligentes. Logo, a informática é uma linguagem simbólica em todas as suas variantes, transmitindo conhecimentos à sociedade.

As Novas Tecnologias da Comunicação e Informação na Educação - NTIC devem ser entendidas como sendo um conjunto de recursos não humanos dedicados ao armazenamento, processamento e comunicação da informação, organizados num sistema capaz de executar um conjunto de tarefas. Portanto, a inclusão social e digital da Pessoa com Deficiência deverá ser percebida, através de um olhar pesquisador, considerando a democratização da comunicação como um terreno propício à construção da sociedade inclusiva. 
E surge a indagação: Qual o papel da informática na construção da sociedade inclusiva?

$\mathrm{Na}$ sociedade da informação, a acessibilidade ao conhecimento digital permite ao incluído digital maximizar o tempo e suas potencialidades. A informática representa mais que um domínio de uma linguagem; é também um suporte para melhorar as suas condições de vida.

A inclusão digital nos dá a possibilidade de comunicar a concepção que temos das coisas, através de procedimentos como compartilhar informações e encontrar informações úteis para própria pessoa com deficiência e sua família.

A inclusão digital é mais importante para as pessoas com deficiência do que para as demais. Porém, o acesso não deve estar limitado somente à rede de informações, mas deve incluir a eliminação de barreiras arquitetônicas, equipamentos e programas adequados, além da apresentação de conteúdos em formatos alternativos que permitam a compreensão por pessoas com deficiência.

A pessoa com deficiência pode adquirir maior independência através de atividades digitais. Através da internet, ela pode encontrar páginas de suma importância relativas a serviços de saúde, educação, trabalho etc.

O ser humano é um inventor de símbolos que transmite idéias complexas sob novas formas de linguagem. O estímulo a projetos de adaptação de equipamentos e programas de informática, desenvolvimento de projetos em tecnologia de assistência (apoio) e a disponibilização em todos os órgãos educacionais de recursos tecnológicos destinados a pessoas com deficiência.

A necessidade de incluir digitalmente as pessoas com deficiência reforça a importância da criação de páginas governamentais que atendam às necessidades especiais dos usuários e usuárias 
dentro do conceito de desenho inclusivo justificando conteúdos de interesse específicos para a área de deficiência.

Os resultados de censo demográfico realizado pelo Instituto Brasileiro de Geografia e Estatística em 2000 mostram que cerca de $14,5 \%$ da população brasileira apresenta algum tipo de deficiência, o que representa aproximadamente 24,5 milhões de pessoas. Embora seja uma parcela grande da população, essas pessoas ainda encontram grandes dificuldades no meio social devido às barreiras existentes, sendo elas arquitetônicas, atitudinais e sistêmicas (SASSAKI, 1998).

A falta de acessibilidade na cidade a locais públicos também pode representar um obstáculo para que as pessoas com deficiência tenham acesso às NTIC, pois ao menos que tenham computador em casa, o que não é a realidade da maioria dessa população, essas pessoas enfrentam problemas no acesso a locais que oferecem esse tipo de tecnologia como lan-houses, cybercafes e telecentros.

A informática vai além de uma significação simbólica, é uma forma de inserção social, conquista de anseios, sonhos, ultrapassa os obstáculos físicos, tornando reais sonhos nos fazendo descobrir e conhecer o mundo.

A internet é a principal ferramenta para promover o contato e discussão da temática da Inclusão entre pessoas com deficiências, familiares, profissionais, formuladores de políticas públicas, instituições de ensino e pesquisa e organizações da sociedade civil. $\mathrm{O}$ computador é uma das principais fontes de informação; atualmente os que não têm acesso ao mundo virtual podem ser considerados "analfabetos digitais", tendo reduzidas suas oportunidades profissionais, culturais e educacionais.

A necessidade de acessibilidade e de eliminar barreiras, para as pessoas com deficiências, como se pode ver na mídia, já tocou as esferas governamentais. Isso pode ser comprovado com a publicação 
do decreto federal 5.296/2004, da criação da Secretaria Especial da Pessoa com Deficiência e Mobilidade Reduzida - SEPED.

Vale relembrar que é competência do poder público promover e fiscalizar a implantação da acessibilidade em todos os sentidos, inclusive no tecnológico, considerando que não haja exclusão de nenhum cidadão - independente de sua raça, cor, sexo, crença, classe social, idade e condição física, sensorial e mental.

A importância da nossa pesquisa tem por base o princípio de que é através das tecnologias da informação e comunicação podemos buscar os meios que venham revelar a capacidade da Pessoa com Deficiência na expressão do sentimento, da sensibilidade, da percepção, do tato, da intuição e do pensamento, relacionando o mundo interior com as modificações do mundo exterior.

A imaginação provocada pela palavra, pelo desenho, pela escrita não se restringe a conceitos, formas ou convenções. Construir novas leituras da realidade, que antes seria impossível representa "dizer virtualmente"verdades negadas que podem adquirir uma força social imensa. Portanto, consideramos a informática elemento construtor da Sociedade Inclusiva.

\section{Compreensão fenomenológica e as ntic na educação inclusiva}

Frente às mudanças contemporâneas, existe um ambiente favorável às pessoas com deficiência para atuarem junto às novas tecnologias independentemente de possuírem limitações visuais, físicas, auditivas, mentais ou múltiplas.

Com a finalidade de entender a compreensão de existência, sentido, percepção da pessoa com deficiência frente às NTIC, abordaremos a concepção fenomenológica, por oferecer apoio à 
compreensão da corporeidade da pessoa com deficiência a cerca da relação ser humano- máquina.

Nossa proposta foi descrever o fenômeno da existência e/ou ausência de laboratórios tecnológicos nas instituições de educação especial no município de Campina Grande, posto que a proposta fenomenológica tem por finalidade descrever a experiência vivida tal como ela é.

De Kant, Hussel (2000) conserva a afirmação de que não conhecemos uma realidade em si, mas a realidade tal como aparece ao ser estruturado e organizado a priori pela razão; de Hegel, Hussel (2000) conserva a afirmação de que a fenomenologia é a descrição do que aparece à consciência e a descrição do aparecer da consciência a si mesma (MERLEAU-PONTY, 1994).

Para Hussel (2000), a descrição fenomenológica exige a ação da "epochê suspender o juízo sobre alguma coisa de que não se tem certeza". A epochê fenomenológica consiste em "colocar entre parênteses nossa crença na existência da realidade exterior e descrever as atividades da consciência ou da razão como um poder a priori de constituição da própria realidade" (LUIJPEN, 1973, p. 23).

Neste sentido, o mundo ou a realidade representa um conjunto de significações ou de sentidos que são produzidos pela consciência ou pela razão. A razão é dotada de sentido enquanto sistema de significações. Estas significações tornam-se o conteúdo que a própria a razão oferece a se mesma para doar sentido e este é a única realidade existente para a razão.

Todo ser humano possui a capacidade de sentir e, consequentemente, de conhecer os sentidos, as formas e totalidades daquilo que está posto ao seu redor ou as suas mãos. E quando a pessoa com deficiência conhece algo como uma NTIC, efetiva-se substancialmente uma relação sujeito corporal e de significação no contato, e 
tudo passa a ter então uma vivência corporal onde o que é percebido passa a ter sentido e lhe é atribuído significado a vida do sentinte.

Através da relação sujeito-objeto se propicia experiência, torna-se uma conexão direta com o mundo exterior, sendo formada uma espécie de mosaico estruturado, composto de partes não isoladas, mas dotadas de sentido. Quando, por exemplo, uma pessoa cega vê uma paisagem produzida através da leitura visual do objeto por meio do JAWS, com a finalidade de resgatar as sensações imbuídas na imagem criada pelo software; em seguida, se particulariza o sentimento quando o admirador procura abstrair o sentido individual da imagem e/ou da informação.

Na verdade, a percepção é uma relação do sujeito com o mundo, em que há uma relação físico-fisiológica, pois o mundo percebido de forma qualitativa e significativa.

O mundo percebido é qualitativo, significativo, estruturado e estamos nele como sujeitos ativos, isto é, damos as coisas percebidas novos sentidos e novos valores, pois as coisas fazem parte de nossa vida e nós interagimos com o mundo (CHAUÍ, 2003, p. 135).

Mas, para que haja percepção se faz necessária a relação das coisas com o corpo da pessoa com deficiência, porque seu corpo não atua sozinho, ele se define no social. Através da relação ser humano- máquina tem início à percepção de existência e atuação no meio externo. É como se os sentidos falassem para o próprio corpo que ele existe porque interagem com o mundo e com as coisas a sua volta por intermédio do computador.

O homem não possui um corpo natural apenas, mas também um corpo cultural e um corpo social. Meu corpo cultural é a facticidade que fica em minha existência como 
resultado de minhas ações pessoais. Meu corpo social é a facticidade que, no ser com os outros e por eles, se deposita em minha existência. (LUIJPEN, 1973, p. 268).

A pessoa com deficiência percebe, através de sua vivência corporal e interação com os meios midiáticos, o mundo a sua volta, com a finalidade de recriar e criar formas que possibilitem a amplitude de conhecimento e de suas potencialidades mediante a interação com a máquina.

O mundo percebido é um mundo intercorporal, isto é, as relações se estabelecem entre nosso corpo, o corpo dos outros sujeitos e o objeto, de modo que a percepção é uma forma de comunicação corporal que estabelecemos com os outros e com as coisas; (CHAUí, 2003, p. 135).

A percepção através da apuração fina dos sentidos, permite que as pessoas com deficiência entrem em contato com o meio externo, percebendo o mundo que lhes é apresentado, numa relação sujeito e objeto, a exemplo de dados recolhidos na nossa pesquisa: uma pessoa com paralisia cerebral- PCque não tem controle psicomotor manual utiliza movimenta o mouse com a ajuda dos pés(ver anexos). Enquanto que outra usuária move utiliza os comandos do teclado usando uma vareta pressa na arcada dentária.

A percepção depende das coisas e de nosso corpo, depende do mundo e de nossos sentidos, depende do exterior e do interior... trata de uma relação complexa entre o corpo-sujeito e os corpos-objetos num campo de significações visuais, táteis, olfativas, sonoras, motrizes, espaciais, temporais e lingüísticas. A percepção é uma conduta vital, 
uma comunicação corporal com o mundo, uma interpretação das coisas e uma valorização delas (belas, feias, agradáveis, desagradáveis, fáceis, difíceis, úteis, inúteis, desejadas, indejesadas, prazerosas, dolorosas, etc.), com base na estrutura de relação entre nosso corpo e o mundo; (CHAUÍ, 2003, p. 135).

Ser no mundo com o corpo é estar engajado, atado, aberto a este mundo. O filósofo Merleau-Ponty (1994) modifica várias idéias de Hussel (2000). Para Merleau-Ponty (1994) a nova ontologia parte da afirmação de que todo ser humano está no mundo e de que o mundo é mais velho do que nós (isto é, não esperou o sujeito do conhecimento para existir). Portanto, a pessoa com deficiência é capaz de dar sentido ao mundo, conhecê-lo e transformá-lo, sendo uma consciência encarnada num corpo, habitado e animado por uma consciência. "O corpo é o veículo do ser no mundo, e ter um corpo é, para uma pessoa viva, juntar-se a um meio definido, confundir-se com alguns projetos e engajar-se continuamente neles" (MERLEAU-PONTY, 1994, p. 94).

A noção de corpo na filosofia de Merleau-Ponty (1994) encarna a possibilidade de compreensão dos gestos e das palavras, constituindo o caráter corpóreo da significação, cuja apreensão está na reciprocidade de comportamentos vividos na dimensão social. Merleau-Ponty (1994) observa uma imanência do sentido na palavra, apontando que a compreensão da linguagem remonta à análise de seu movimento expressivo originário: o gesto que propõe a tomada de mundo na articulação do ser social e, no caso da nossa pesquisa a relação de linguagem está baseada na subjetivação das NTIC frente à relação corporal da pessoa com deficiência.

O caráter fundador da relação ser humano-mundo mostra-se, nas relações ambíguas, entre fala e pensamento, sentido e palavra, significante e significado. Esta ambiguidade, presente em todas as formas de linguagem, inclusive na linguagem midiática constitui a 
natureza do fenômeno expressivo, revelando a abertura de nossa faticidade originária ao mundo.

Diante desta perspectiva o corpo da pessoa com deficiência é concebido na sua totalidade. Um corpo vivo, presente, em movimento, com expressão, dotado de intencionalidade, de motricidade, comunicação e perceptivo, apropriando-se do movimento ser humano- máquina com maior intensidade a fim de conhecer o mundo a sua volta.

A percepção seria a chave para o entendimento e a construção da realidade. Esta percepção se dá através do corpo da pessoa com, deficiência, assim consciência e corpo são inseparáveis; simultaneamente, ser humano e computador estão interligados. A relação dualista entre máquina e a pessoa com deficiência forma uma unidade de abstração: o corpo como coisa pensante e objeto pensado ao mesmo tempo, o que pensa e sente e o que se torna objeto de pensamentos.

Neste contexto, as NTIC possibilitam uma coleta de informações sobre os objetos próximos e distantes. Conforme a proposta fenomenológica, a descoberta e exploração dos objetos são realizadas por meio do corpo. Durante a leitura tátil, o toque das mãos da pessoa cega segue o espaço, a área, linhas, curvas e texturas de um teclado ou mouse contribuindo de forma significativa no processo de envolvimento da aprendizagem elo corporal com o mundo.

Para a pessoa com deficiência, as NTIC representam o veículo da visibilidade no meio dos outros seres visíveis. Ele vê além do visível ocular. Seu corpo é um ser táctil, pode ser tocado e tocante, como, por exemplo, quando o software JAWS através da audição proporciona a pessoa cega uma leitura de mundo.

Assim, neste entrelaçado de sentir, perceber e vislumbrar o mundo a sua volta a pessoa com deficiência independentemente da 
limitação física que possui, entrega-se ao contato com o computador e a Internet objetivando aprimorar sua aprendizagem.

Evidencia-se desta forma, a importância das NTIC para a pessoa com deficiência, propiciando-a acessibilidade de ver o que antes era obscuro, a ouvir o que sempre se ouvia, com intensidade, de sentir o que antes parecia imperceptível, a desenhar um animal na tela do computador usando sensores presos a cabeça, brincar e rodopiar através do second life:

A quase eternidade da arte confunde-se com a quase eternidade da existência humana encarnada e por isso temos, no exercício de nosso corpo e de nossos sentidos, com que compreender nossa gesticulação cultural, que nos insere no tempo (MERLEAU-PONTY, 1967 apud CHAUÍ, 2003, p. 270).

O discurso fenomenológico mostra que as sensações e percepções são pontuais, ou elementares, porque ao mesmo tempo a pessoa com deficiência sente e percebe formas, totalidades estruturadas dotadas de sentido ou de significação.

A Declaração Universal dos Direitos Humanos publicada em 1948, no seu artigo 27, declara que "As descobertas científicas devem servir a todos. Um sábio, um artista, um escritor deverão ser felicitados e pagos por sua contribuição e ninguém tem o direito a tomar para si à invenção do outro" (BRASIL, 2004).

Neste sentido, ao mesmo tempo em que a pessoa com deficiência cria, inova, descobre, amplia seus conhecimentos tecnológicos se afirma como ser cidadão/a no momento de desfrutar as NTIC.

Portanto, se evidencia no micro espaço o direito à liberdade, à luta contra a discriminação. Em função da pressão social, surgem as diferentes políticas públicas de Estado como fruto de um construto social e respeito à diversidade, objetivando criar instrumentos 
legais que asseguram direitos de inclusão digital. Direitos esses, que com certeza englobam também a cidadania planetária.

A fim de assegurar tais direitos, o Brasil participou da Conferência Mundial sobre Necessidades Educativas Especiais: Acesso e Qualidade, realizada pela Unesco, em Salamanca (Espanha), em julho de 1994, que teve a atenção voltada para a educação especial, tendo como meta a participação social:

Promover e facilitar a participação de pais, comunidades e organizações de pessoas com deficiência, no planejamento e no processo de tomada de decisões, para atender alunos e alunas com necessidades educacionais especiais. (BRASIL, 2004)

Fica evidente que a intenção alicerçada na Declaração de Salamanca, já considerava os princípios da educação inclusiva e incentiva a participação política através de organizações de pessoas com deficiência, oferecendo margem de poder para organizações voltadas para o desenvolvimento. Como também na Convenção da Guatemala realizada em 1999, intitulada Convenção interamericana para a eliminação de todas as formas de discriminação contra as pessoas com deficiência.

\section{Inclusão e as NTIC em Campina Grande: contextualizando a pesquisa}

A pesquisa foi planejada e desenvolvida em 2007-2008, durante o curso de Pós-Graduação em Novas Tecnologias na Educação da Coordenação Institucional de Programas Especiais- CIPE da Universidade Estadual da Paraíba. 
A carência de estudos que contemplassem a realidade local mobilizou o levantar e analisar dados sobre a utilização de ferramentas digitais junto às pessoas com deficiências investigando quais os meios e recursos informatizados em situações de ensinoaprendizagem e a sua relação com a corporeidade das pessoas com deficiências.

As NTIC permitem através da atuação em rede, a interação das pessoas com deficiências pela democratização de espaços e ferramentas que facilitam o compartilhamento de saberes, apesar dos esforços das instituições pesquisadas.

Conforme gráfico abaixo fica visível o acesso às tecnologias nas entidades revelando a necessidade de políticas pública que garantam que adentrar ao mundo informatizado.

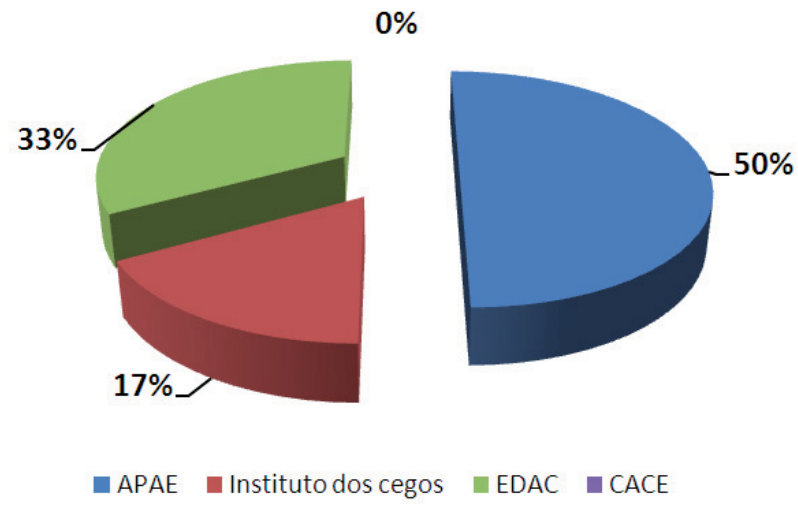

Gráfico 1- Quantidade de computadores funcionando nas instituições pesquisadas. 
Atualmente, educadores e educadoras, pesquisadores e pesquisadoras destacam o potencial das NTIC em relação à dinamização e ampliação das habilidades que as ferramentas e mídias digitais oferecem à aprendizagem de pessoas com deficiências, portanto, a hipermídia representa:

tecnologias intelectuais que amplificam, exteriorizam e modificam numerosas funções cognitivas humanas: memória (banco de dados, hiperdocumentos, arquivos digitais de todos os tipos), imaginação (simulações), percepção (sensores digitais, telepresença, realidades virtuais), raciocínios (inteligência artificial, modelização de fenômenos complexos).(LÉVY, 2000, p.157).

A inclusão digital é incompatível com modelos educacionais baseados no exercício de poder do docente, da comunicação unilateral, no exercício repetitivo, no controle do discente. Assim as NTIC geram à possibilidade de comunicação, informação, cooperação e colaboração, extensão da memória, a publicação de informações e mensagens, por serem instrumentos capazes de junto as pessoas com deficiências renovar as situações de interação, expressão, criação, de modo muito diferente das tradicionalmente fundamentadas na escrita através dos meios impressos.

\section{As novas tecnologias e as repercussões educativas em Campina Grande}

Registramos a utilização do software DOSVOX no Instituto dos Cegos, servindo de referencial para a educação de pessoas cegas, principalmente pelo seguinte motivo: ser um sistema digital flexível e adaptável especialmente modelado para pessoas cegas, possibilitando a navegação e exploração em diferentes contextos, permitindo 
a adequação e inserção de dados, conforme o planejamento didático pedagógico da professora e os interesses dos alunos e alunas.

Atualmente existem diversos programas para micro-computadores que permitem que uma pessoa com deficiência visual interaja com a máquina de forma muito conveniente. Para as pessoas totalmente cegas existem leitores de telas (JAWS) que falam tudo que está sendo digitado ou tudo que aparece na tela do micro; para as pessoas de visão subnormal, existem programas que ampliam as letras da tela do computador.

\begin{tabular}{cc}
\hline Instituto dos Cegos & \\
\hline Memocas (linguagem e matemática) & 1 \\
Escola diversão (maternal e alfabetização) & 1 \\
Coleção Sesinho & 1 \\
Sites Educativos (Tia Andréa, Sítio) & 1 \\
Dosvox & 1 \\
JAWS & 1 \\
Micromundos & 1 \\
Tux paint & 1 \\
\hline
\end{tabular}

Tabela 1- Softwares e Sites utilizados nos laboratórios de informática

O leitor de tela denominado JAWS na versão 5.0 é considerada a mais atualizada, tendo em vista que utiliza a linguagem em português, embora, alguns comandos ainda falhem. Funciona em qualquer página da internet ou qualquer software necessário. À medida que as páginas vão sendo abertas, utilizando-se das setas para cima e para baixo, a leitura oral vai sendo realizada, podendo esta, ainda, ser aumentada ou diminuída em sua velocidade, escolhendo também se prefere a voz do homem ou da mulher para ser ouvida. 
Através do DOSVOX a pessoa com deficiência visual estabelece o primeiro contato com o computador, considerando que o programa faz leitura oral. Aos poucos a pessoa com deficiência visual se familiariza com o teclado, visto que não usa o mouse.

Percebemos que, com a criação do sistema DOSVOX, as pessoas com deficiência visual passaram a utilizar o computador, para executar tarefas como edição de textos (com impressão comum ou Braille) leitura/audição de textos anteriormente transcritos, utilização de ferramentas de produtividade faladas (calculadora, agenda, etc), além de diversos jogos.

$\mathrm{Na}$ contemporaneidade, esse sistema vem sendo utilizado por mais de 500 cegos de todo Brasil, devido o seu custo muito baixo - o sistema foi industrializado e nos dias atuais pode ser comercializado por menos de 100 dólares.

As pessoas com deficiência visual, seja ela total ou parcial, conseguem realizar de forma eficaz desde as mais simples digitações até o acesso a Internet por meio do Sistema Operacional DOSVOX, desenvolvido para este público alvo, e que dispõe de recursos de som e de magnificação de tela.

A partir do DOSVOX, qualquer pessoa cega pode ler livros, jornais e revistas virtuais. $O$ aparelho permite que cada letra e sílaba sejam sonorizadas pelo computador. Assim, quando uma pessoa cega quer ler um livro ou revista ela coloca as páginas no SCANER e o computador dita as sílabas.

No Instituto dos Cegos, através do uso do DOSVOX os alunos e as alunas passaram a fazer seus trabalhos de modo que ocorra uma compreensão pelos professores e professoras.

Segundo Mantoan (2003), a educação atualmente se depara com novos desafios, entre eles, o de estabelecer condições mais adequadas para entender a diversidade dos sujeitos sociais que a formam. Neste sentido, nossa proposta vislumbra o desejo de que 
através da inclusão tecnológica educacional, seja possível a conquista de um espaço com práticas educacionais e sociais inclusivas, ampliando as condições e oportunidades da corporeidade de pessoas com deficiências.

A nossa pesquisa segue a linha da micro-história, no dizer de Vainfas (2002) perseguindo uma "pratica historiográfica" de modo a registrar a acessibilidade aos recursos da informática da Pessoa com Deficiência, que ajudarão a analisar e compreender a importância das tecnologias de informação e comunicação na construção da inclusão digital e social.

Em nosso trabalho, buscamos a construção teórica, tomando como referência uma bibliografia em favor da inclusão social como nos faz ver, Sassaki (1998), alicerçada numa educação que defende a proposta inclusiva ao respeitar a capacitação intelectual respeitando as políticas sociais ao tratar à temática: inclusão digital das pessoas com deficiência.

Foram descritas as características da população e os recursos tecnológicos existentes nas instituições APAE e no Instituto dos Cegos, considerando que na pesquisa foi possível mapear que as instituições $\mathrm{CACE}$, EDAC, ICAE não possuem laboratório de informática, apesar de no EDAC detectar a existência de oito computadores que, no entanto, não foram instalados impedindo lamentavelmente a implantação do laboratório de informática negando o acesso da comunidade de 350 usuários/as matriculados/ as. Entretanto, nos foi informado que a escola mantém convênio com a Universidade Federal de Campina Grande - UFCG facultando acesso às pessoas surdas através de cursos ministrados por aquela IES. Existe ainda convênio com o SENAI e SESI que oferece cursos de informática para os alunos e alunas do EDAC com o auxílio de intérpretes de LIBRAS.

Atualmente, o Instituto de Educação e Assistência aos Cegos do Nordeste, funciona no sistema integral atendendo cerca de 
180 pessoas com deficiência visual, entre cegos (as) e pessoas de baixa visão, lhes oferecendo gratuitamente serviços nas áreas de educação, saúde, assistência social, música, informática e desportes adaptados, como também alojamento e alimentação. Destas, 180 pessoas com deficiência visual apenas 40 delas tem acesso ao laboratório de informática. Estes serviços vão muito além da área urbana e rural do município de Campina Grande, atingindo todo o compartimento da Borborema e do Nordeste.

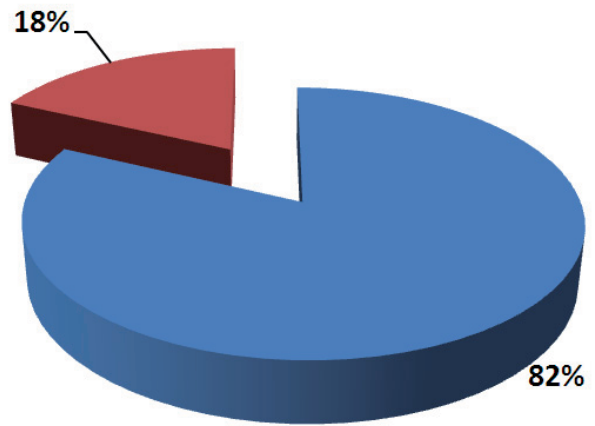

- Pessoas que freguentam o Instituto dos Cegos

- Pessoas com acesso ao laboratório

Gráfico 2- Instituto dos Cegos - Quantidade de usuários/as dos laboratórios de informática

O atendimento escolar tem sido realizado desde a educação infantil até o ensino fundamental, vindo a oferecer também supletivo, aulas de locomoção, atividade da vida diária, música. O Instituto atende alunos e alunas de todas as idades, sendo alguns encaminhados para as salas de aceleração onde são utilizadas diversas e criativas maneiras que venham a suprir eventuais atrasos na vida escolar.

O corpo docente é constituído por professores (as) qualificados e habilitados nas diversas áreas de atuação. Todos os (as) instru- 
tores (as) são especialmente treinados e orientados para o ensino especial. Estes treinamentos são oferecidos pela própria entidade.

O Instituto dos Cegos dispõe de um considerável grupo de voluntários que atuam nas diversas áreas de conhecimentos. Por exemplo, a biblioteca dispõe de voluntários videntes e ledores111, os quais lêem e gravam revistas, livros, apostila para os estudantes que ainda não desenvolveram a técnica de leitura.

A Associação de Pais e Amigos dos Excepcionais - APAE do município de Campina Grande foi fundada em 1983 pelo Rotary Clube de Campina Grande-Oeste, tendo sido reconhecida de utilidade pública pelos Governos Federal, Estadual e Municipal. Na época, o então governador Ronaldo Cunha Lima fez a desapropriação de uma casa onde funcionou a sede inicial. Posteriormente, o então prefeito, naquela oportunidade Cássio Cunha Lima, doou um terreno e 300 mil reais e, juntamente com a contribuição da comunidade, foi construída ao lado do terminal rodoviário a sede da APAE, em Campina Grande.

Filiada à Federação Nacional das APAE's tem como objetivo a defesa dos direitos, o atendimento da pessoa com deficiência mental e/ou múltipla. A instituição conta com noventa e nove profissionais e tem como filosofia promover e articular ações de defesa, direitos, prevenção (teste do pezinho), orientação, apoio à família, direcionado à melhoria da qualidade de vida da pessoa com deficiência e a construção de uma sociedade justa e solidária.

A APAE atende a mais de 534 usuários e usuárias sem limite de idade. Oferece serviços clínicos como: fisioterapia, fonoaudióloga, bem como serviços educacionais a exemplo da psicologia pedagógica, laboratório de informática, biblioteca e programas de leitura numa perspectiva de Inclusão Social.

11 Todas as pessoas que possuem uma visão considerada de boa qualidade. 
Destacamos a inclusão digital oferecida pela entidade que disponibiliza a comunidade usuária programas, tais como: tecnologias assistidas, softwares memocas, linguagem e matemática, escola diversão do maternal a alfabetização, coleção do sesinho que trabalha os elementos da natureza, site do Sítio do Pica-Pau-Amarelo e de histórias infantis.

O laboratório de informática sob a responsabilidade da professora Cleonice Maria de Lima Oliveira funciona com quatro turmas diárias, com atendimento de uma hora semanal cada uma, devido ao grande número de inscritos na instituição e o pequeno número de computadores. Os computadores são adaptados de acordo com a necessidade de cada aluno e aluna em sua aula, assim, os alunos com deficiência física, paralisia cerebral e múltipla, não sofrem menor exclusão, ao contrário, através da tecnologia, estão cada vez mais interagindo com o mundo que estão inseridos, a inclusão tecnológica é um forte aliado na nossa sociedade.

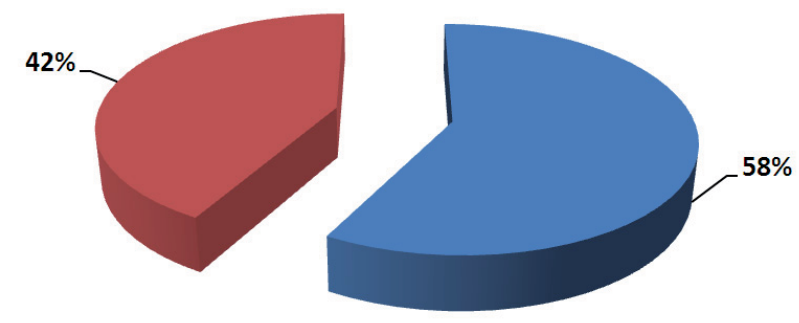

- Pessoas que freguentam a APAE —Pessoas com acesso ao laboratório

Gráfico 3 - APAE - Quantidade de usuários/as dos laboratórios de informática

Enfim, os dados descritivos revelaram a importância do contato direto e interativo com os laboratórios de informática das instituições pesquisadas onde procuramos compreender a relação ser humano máquina e inclusão digital no município de Campina Grande- PB. 


\section{Considerações finais}

O estudo apresentou dados que permitem algumas reflexões sobre o processo de inclusão digital de pessoas com deficiência. Imbuídos da necessidade de mapear e conhecer as NTIC disponíveis nas instituições pesquisadas.

Os principais resultados indicaram que a maioria dos/as usuários/as que participaram dessa pesquisa se mostraram favoráveis aceitação e a credibilidade da inclusão digital como meio de localização espacial e social frente às dificuldades das limitações decorrentes da deficiência.

A proposta da inclusão social deve começar antes da existência de uma pessoa com deficiência. Começa com a nossa história, passa pela concepção, nascimento e fases episódicas da vida, marcadas pela escolarização, profissionalização, vida afetiva e continua até a morte.

Os desafios que se sucedem são medidas que se abrem os campos de ação. Cada situação desconhecida exige uma atitude nova, um novo comportamento. Quanto mais arriscamos ficamos mais sujeitos a enfrentar situações cada vez mais complexas. Só quem não arrisca não comete erros e também não acerta, ficando paralisado sem o impulso da ação.

A inclusão digital de pessoas com deficiências começa desde o início da escolarização, é possível mediante condições apropriadas. Outro aspecto a ser salientado é o fato de que, nos últimos anos, as pessoas com deficiência estão assumindo sua própria voz. Antes, havia sempre quem falasse por eles em nome de suas necessidades sem nunca consultá-los. O movimento pró-inclusão digital das pessoas com deficiência é recente, porém representa um avanço às malhas da segregação. 
Constatamos que, apesar do tema proposto ser muito polêmico, o mesmo é aceito nas discussões contemporâneas, pois trata de um assunto que está sendo evidenciado na mídia.

As manchetes televisivas da atualidade informam e alertam o telespectador sobre as capacidades físicas, sociais e emocionais das pessoas com deficiência. Destacamos neste cenário de embates políticos a luta dos grupos pro-inclusão digital, a priori, tem contribuído de forma significativa para desmistificar os preconceitos existentes na sociedade brasileira.

Entretanto, os dados deixam explícitos que ainda se faz necessário muito investimento, bem como estudo e conhecimento das NTIC, frente às necessidades das pessoas com deficiências. Se faz necessária a definição de uma política que subsidie princípios e práticas para as necessidades educativas especiais, construindo a inclusão digital que gere a igualdade de oportunidades para as pessoas com deficiência.

O processo de inclusão digital requer não apenas a aceitação e a credibilidade das pessoas envolvidas com a pedagogia, mas também que as instituições se estruturem tanto no âmbito físico como de recursos humanos para implantação de laboratórios que atendam a demanda de pessoas com necessidades educativas especiais, respeitando tanto estilos como ritmos diferentes de aprendizagem garantindo a acessibilidade tecnológica a todos os seres humanos.

Assim, a inclusão digital extrapola os limites temporais e espaciais da sala de aula por oportunizar atos comunicativos multimeios para as pessoas com deficiências através de atividades cooperativas e colaborativas, oferecendo acesso a diversos tipos de informações.

A importância das linguagens midiáticas proporciona a pessoa com deficiência desenvolver suas habilidades, se comunicar e movimentar em um mundo mediado pela tecnologia, de modo a 
se adaptar a diferentes situações. Seguindo tal paradigma, destaco a importância da interatividade como proposta de valorização da rede de conhecimentos que as pessoas com deficiências constroem no desenvolvimento de novas competências comunicativas.

Do ponto de vista pedagógico, a informatização do ambiente de aprendizagem enfatiza a inclusão digital no universo da educação especial reunindo um conjunto de atividades que perpassam mecanismos que oportunizam a livre expressão, organização e formação de um espaço midiatizado, gerando a identidade de um grupo de navegadores e navegadoras no ciberespaço, sob orientação e acompanhamento do corpo docente.

Notamos, ao longo da pesquisa, que a sociedade de forma geral, ainda não absorveu as informações com o intuito de realmente pôlas em prática. Notamos que as informações sobre as pessoas com deficiência são recebidas apenas para um ligeiro impacto que produzem meras emoções efêmeras ou sentimentos de piedade.

O estatuto da pessoa com deficiência, defendido pelo Senador Paulo Paim assegura o incentivo ao desenvolvimento intelectual das pessoas com deficiência, no entanto a ausência de laboratórios em algumas instituições pesquisadas demonstra uma visível exclusão digital.

Mesmo diante desse panorama, constatamos que existe uma inquietação por parte de alguns professores e professoras, psicólogos e psicólogos, assistentes sociais e demais profissionais comprometidos com a inclusão digital. De certa forma, isto se dá pelo fato das instituições não possuírem ainda condições infra-estruturais adequadas, e materiais tecnológicos direcionados especificamente às deficiências particulares de cada pessoa com deficiência aliados a escassez de cursos de capacitação tecnológica para o corpo docente, em nível de graduação, extensão e, sobretudo de pós-graduação. 
Talvez, se o corpo docente não fosse obrigado a redobrar a carga horária por dia, por motivos financeiros, certamente teriam condições de buscar cursos de aperfeiçoamentos. E se as entidades tivessem mais recursos financeiros, talvez possuíssem materiais mais adequados e posturas propícias para com as pessoas com deficiência, aliados a uma assistência tecnológica à família da pessoa com deficiência usuária das instituições.

Diante de todos os fatos apresentados, persistimos na busca por mais pesquisas e investigações para que se construa uma estrutura de embasamentos teóricos e práticos que permitam a realização de uma sociedade com equidade, mais justa e livre para todas as pessoas com deficiência; pois elas, apesar de possuírem limitações, têm o direito, assegurado pela Constituição Federal de 1988. E o que nos resta é construirmos com e para elas o direito à: vida, arte, liberdade, igualdade, acessibilidade as NTIC, segurança, e lazer, porque são, sem distinção de qualquer natureza, iguais perante a lei, considerando que são cidadãos e cidadãs brasileiros/as.

Compreendemos desta forma que as NTIC se caracterizam como uma das mais abertas vias para a perspectiva da inclusão digital da pessoa com deficiência. A capacidade inventiva humana para criação de artefatos científicos que podem ser utilizados como instrumentos de formação ou transmissão de cultura, ou seja, de inclusão social e digital da pessoa com deficiência através do desenvolvimento da percepção de cada ser possibilitando perceber ou conhecer o mundo à sua volta.

Concluímos que se faz necessário muito estudo e pesquisa para ampliar o conhecimento tecnológico, desenvolver softwares e testar formas de atuação junto às pessoas com deficiência que viabilizem a verdadeira inclusão digital. Enfim, este estudo deixa evidente a complexidade e a abrangência do tema, sendo portanto impossível à conclusão, ou melhor, esgotá-lo nas dimensões desse estudo, sugerindo-se que outras pesquisas sejam realizadas. 


\section{Referências}

ALAVA, S. et al. Ciberespaço e formações abertas: rumo a novas práticas educacionais. Porto Alegre: Artmed, 2002.

ARANHA, M. S. F. (Org.). Educação inclusiva: a fundamentação filosófica. 2. ed. Brasília: MEC, Secretaria de Educação Especial, 2006.

ASSMANN, H.. Paradigmas Educacionais e corporeidade. 3. ed. Piracicaba: Unimep, 2005.

BRASIL. Ministério da Justiça. Declaração de Salamanca e Linha de Ação sobre Necessidades Educativas Especiais. Brasília: CORDE, 1994.

BRASIL. Constituição da República Federativa do Brasil: texto constitucional promulgado em 5 de outubro de 1988, com as alterações adotadas pelas Ementas Constitucionais nos 1/92 a 43/2004 e pelas Emendas Constitucionais de Revisão nos 1 a 6/94. Brasília: Senado Federal, Subsecretaria de Edições Técnicas, 1998.

BRASIL. Congresso Nacional. Lei de Diretrizes e Bases da Educação Nacional. Lei nº 9394/96. Brasília: Centro Gráfico, 2002.

BRASIL. Ministério da Educação. Programa de Educação Inclusiva: direito a diversidade. A fundamentação filosófica. Brasília : MEC, 2004.

CHAUI, M. Convite à filosofia. São Paulo: Ática, 2003.

1 CONFERÊNCIA Nacional dos Direitos da Pessoa Portadora de Deficiência. CAO-PPDI Boletim Informativo do Centro de Apoio Operacional das Promotorias de Justiça de Defesa das Pessoas Portadoras de Deficiência e dos Idosos. 2006. Disponível em: <www. mp.mg.gov.br/caoppdi/BoletimCaoppdi4.pdf $>$. Acesso em: 24 de abril de 2008. 
CARVALHO, R. E. Removendo barreiras para a aprendizagem: educação inclusiva. Porto Alegre: Mediação, 2000. 174 p.

CASTELLS, M. A Galáxia da Internet: reflexões sobre a internet, os negócios e a sociedade. Rio de Janeiro: Jorge Zahar Editor, 2003.

HUSSERL, E. A Idéia da Fenomenologia.Rio de Janeiro: Edições 70, 2000.

LÉVY, P. Cibercultura. 2.ed. São Paulo: Editora 34, 2000.

LUIJPEN, W. A. M. Introdução à Fenomenologia Existencial. São Paulo: EPU, 1973.

MANTOAN, M. T. E. Ensinando a turma toda. Pátio, Porto Alegre, ano 5, n. 20, p. 18-19, 2002.

PINSKY, J.; PINSK, C. B. (Orgs.). História da Cidadania. São Paulo: Contexto, 2003.

MERLEAU-PONTY, M. Estrutura do comportamento. Belo Horizonte: Interlivros, 1975.

MERLEAU-PONTY, M. Fenomenologia da percepção. São Paulo: Martins fontes, 1994.

MORAN, J. M. et al. Novas Tecnologias e mediação pedagógica. Campinas: Papirus, 2004.

PAULON, S. M. et al. Documento subsidiário à política de inclusão. Brasília: Ministério da Educação, Secretaria de Educação Especial, 2005.

PERRENOUD, P. Dez novas competências para ensinar. Porto Alegre: Arte Médicas Sul, 2000.

SASSAKI, R. K. A educação especial e a leitura para o mundo: a mídia. Revista Nacional de Reabilitação, ano 2, n. 4, 1998. 
Novos espaços em esporte, lazer e inclusão.

Revista Nacional de Reabilitação, ano 2, n. 3, 1998.

SILVA, M. Sala de aula interativa. Rio de Janeiro: Quartet, 2001.

TEODORO, A. Educar, promover, emancipar: os contributos de Paulo Freire e Rui Grácio para uma pedagogia emancipatória. Lisboa: Edições Universitárias Lusófonas, 2001.

VAINFAS, R. Os protagonistas anônimos da história: micro-história. Rio de Janeiro: Editora Campus, 2002. 



\title{
Os jogos como contextos curriculares: um estudo das construç̄ôes de gênero no "The SIMS"
}

\author{
Anita Leocádia Pereira dos Santos \\ UEPB - Campina Grande, Paraíba \\ anitaleopereira@yahoo.com.br \\ Filomena $\mathbf{M}^{\mathbf{a}}$ Gonçalves da Silva Cordeiro Moita \\ UEPB - Campina Grande, Paraíba \\ filomena_moita@hotmail.com
}

A partir da compreensão dos jogos eletrônicos, doravante denominados games ${ }^{12}$, como uma realidade educacional de efetiva aprendizagem na contemporaneidade, para além de espaços de mera diversão, evidencia-se a necessidade de se desenvolverem pesquisas com o objetivo de se compreenderem as especificidades de tal fenômeno, para um melhor entendimento e aproveitamento de sua utilidade pedagógica (JOHNSON, 2005).

12 Optamos pela expressão games, como referência aos jogos eletrônicos desenvolvidos em computador e /ou aparelhos de videogame, também chamados de jogos digitais, que compõem o universo das novas tecnologias da informação e da comunicação (TICs). 
Para a delimitação deste estudo, elegemos o game "The Sims 2 "13 como contexto educacional, destacando-se a investigação do respectivo ideário de gênero perpassado em sua trama, uma vez que, em estudos anteriores, ficou evidenciado como ficou evidenciado que "a criação da série The Sims que retrata o ambiente familiar e é muito jogada pelas meninas" indica que "os games, enquanto universo predominantemente masculino, ajudam a reproduzir o modelo patriarcal de sociedade"(MOITA, 2007c, p.26).

Por serem aprendidos e ensinados, os conceitos de gênero são perpassados em contextos diversos, em um processo de socialização histórica, em situações educacionais direcionadas e difusas. Entre estas últimas, os games ocupam, cada vez mais, o tempo de crianças e jovens, em um processo educativo informal, porém vigoroso, ainda negligenciado como possibilidade pedagógica e de ressignificação de conceitos, inclusive para a equidade de gênero, o que justifica a importância e a utilidade social desta pesquisa.

Considerando-se a experiência digital com games, como espaços de formação, adotamos uma metodologia qualitativa, por ser útil à nossa abordagem, "pela pertinência do enfoque para obter o ângulo mais adequado do problema em investigação" (BRANDÃO, 2002, p.29), com uso de questionários sobre uma amostra não probabilista por tipicidade (LAKATOS, 2007). O grupo pesquisado constitui-se em um representativo da população usuária de games como um todo. Contamos com a participação de uma jogadoracolaboradora como elo focal, que facilitou o acesso ao campo e contribuiu com a tarefa de interpretar o contexto do "The Sims 2".

$13^{2}$ Delimitamos o volume "The Sims 2", por ser o volume da série mais jogado no momento pelos/as adolescentes que compõem a população pesquisada, de acordo com informações da jogadora elo focal. 


\section{Educação e construç̣̃es de gênero: processo de formaç̦ão humana}

A educação, como fator inerente à socialização, desde a comunidade primitiva até os dias atuais, tem se processado de maneiras informal/assistemática e formal/sistemática, numa constante articulação e interdependência com os demais setores da sociedade. Dessa forma, foram se delineando os paradigmas educacionais, no decorrer da história, numa tensão entre as exigências que a sociedade faz sobre a escola e a própria cultura escolar, construída ao longo de anos, e que se encontra influenciada por reflexões e decisões pedagógicas, através de uma estruturação dialética (BERTRAND; VALOIS, 1999).

Assim, não há como negar a aproximação e o entrelaçamento da educação com o paradigma informacional contemporâneo, nem se pode deixar de reconhecer que "os games se inserem num contexto cultural-curricular juvenil" (MOITA, 2007a, p.58), como elementos de composição do atual paradigma educacional, configurando-se em importante campo de pesquisa educacional, inserido nos estudos sobre educação e tecnologias.

Assim, como a educação é um processo com vistas a um produto complexo, não é possível considerá-la apenas em termos escolares, mesmo que essa seja, sem dúvida, uma de suas principais modalidades, mas como o conjunto de influências e inter-relações que promovem a construção do ser pessoa. De tal forma, compreende-se que:

Educação é um conceito amplo que se refere ao processo de desenvolvimento onilateral da personalidade, envolvendo a formação de qualidades humanas-físicas, morais, intelectuais, estéticas- tendo em vista a orientação da atividade humana na sua relação com o meio social, num determinado contexto de relações sociais. (LIBÂNEO, 1994, p. 22). 
Nesse sentido, o papel do/a educador/a vai muito além de transmitir um conhecimento elaborado e passa a ser fundamentalmente dialógico, numa atitude comprometida com a problematização, com a libertação, visando superar todas as formas de opressão, considerando-se a situação específica e o contexto sócio-histórico, uma vez que "ninguém educa ninguém, ninguém educa a si mesmo, os homens se educam entre si, mediatizados pelo mundo" (FREIRE, 1987, p. 68).

A educação, então, versa como um processo social de modelagem humana, e como as pessoas não dispõem de um programa genético que oriente o seu comportamento, a educação se torna necessária e assume papel determinante como tempo e espaço, para o delineamento de condutas sociais, entre as quais destacam-se, aqui, as articulações entre as construções de gênero e educação, por entendermos a educação como um lugar de crítica, de diálogo, de criação e de transformação cultural. Ao mesmo tempo, sendo a escola principal agência educativa na contemporaneidade, desde a primeira infância, a educação se processa em diversos outros espaços, também atravessados pelas relações de gênero (LOURO, 2000), a exemplo do espaço virtual dos games.

O conceito de gênero, ora adotado, está ligado ao feminismo contemporâneo e assume caráter político e relacional por se referir às relações hierarquizadas entre o masculino e o feminino, produzidas historicamente no campo social (LOURO, 2004). Nessa compreensão, contrapõe-se às argumentações de cunho biologicista, que tentam naturalizar as desigualdades entre homens e mulheres, meninos e meninas. Defende-se que tais produções são processuais e ocorrem nas e pelas relações de poder, evidenciadas nas práticas sociais, constituindo mais que papéis, instituindo identidades.

Conforme Cuche, "no âmbito das Ciências Sociais, o conceito de identidade cultural se caracteriza pela sua polissemia e fluidez" (CUCHE, 2002, p.176). Assim consideradas, múltiplas e instáveis, são, portanto, passíveis de serem modificadas sempre que as 
condições para a sua fabricação sofrem alterações. Concordamos, então, que as identidades e as desigualdades de gênero são produtos da cultura, e não, da natureza.

Ao utilizar o gênero, como categoria de análise, adotamos como referencial a Teoria da Dominação Masculina de Bourdieu. Tal dominação é pautada no androcentrismo, cujas disposições resultam "da incorporação do preconceito desfavorável contra o feminino", que inscreve a ordem masculina sobre todas as coisas e pessoas como legítima, a partir de princípios de visão e de divisão do mundo (BOURDIEU, 2005b, p. 44). Para tanto, faz-se necessária a atuação de uma força que age especialmente no campo institucional: "o poder simbólico como poder de constituir o dado pela enunciação, de fazer ver e fazer crer, de confirmar ou de transformar a visão do mundo e, deste modo, a ação sobre o mundo, portanto, o mundo" (BOURDIEU, 2005a, p.14).

Forjada na construção arbitrária do biológico e do social, produzida e reproduzida em todos os campos, a dominação masculina é viabilizada pela violência simbólica: "uma forma de poder que se exerce sobre os corpos, diretamente, e como que por magia, sem qualquer coação física" (BOURDIEU, 2005 b, p.50), instituída pela adesão do dominado ao dominante, nesse caso, a submissão feminina, e assegurada pela formação de habitus distintos e diferenciadores de estilos comportamentais masculino e/ou feminino. Os habitus são inscrições duradouras das estruturas sociais nos corpos, construções sociais das estruturas cognitivas que funcionam como "matrizes das percepções, dos pensamentos e das ações de todos os membros da sociedade, como transcendentais históricos que, sendo universalmente partilhados, impõem-se a cada agente como transcendente" (Bourdieu, 2005 b, p.45).

As relações de gênero são construções culturais socialmente produzidas como questões de poder e se constituem em problemáticas educacionais importantes, não somente para a compreensão e a desconstrução das desigualdades entre masculino e feminino, 
como também para a promoção e o respeito às novas identidades (CASTELLS, 2002), às novas formas de relacionamento humano e à ressignificação da ordem familiar e política vigente, especialmente no momento presente, em que novos cenários surgem e os preconceitos resistem, gerando discriminações.

Assim, os estudos de gênero visam, também, possibilitar a reflexão e a ação, no sentido de transformar as relações desiguais e iníquas em relações democráticas e igualitárias. Isso significa buscar o respeito e valorizar as diversidades de gênero do pluralismo e da igualdade de direitos entre homens e mulheres.

\section{Os games como currículo cultural}

A aprendizagem não ocorre somente na escola e não existe apenas um tipo de currículo - o escolar. Há contextos curriculares diversos, ressaltando-se, neste momento, o contexto curricular juvenil, que se manifesta nos games (MOITA, 2007a) que, assim como a escola, configuram-se em espaços educativos, marcados pelas construções de gênero, como mecanismos adotados e operacionalizados na esfera da informalidade não-documentada, às vezes, sutil ou imperceptível, eficaz sobre a produção de todos os sujeitos.

Assim, a política curricular nacional explica o currículo:

Atualmente este conceito envolve outros três, quais sejam: currículo formal (planos e propostas pedagógicas), currículo em ação (aquilo que efetivamente acontece nas salas de aula e nas escolas), currículo oculto (o não dito, aquilo que tanto alunos, quanto professores trazem, carregado de sentidos próprios criando as formas de relacionamento, poder e convivência nas salas de aula) (BRASIL, 1998, grifo nosso) 
É possível transpor esses níveis curriculares aos processos evidenciados nos jogos eletrônicos: há uma proposta explícita, pensada e disposta pelo fabricante - o currículo formal; o modo como se joga, a interatividade, a tensão e as habilidades cognoscitivas geradas pelo envolvimento com o jogo - o currículo em ação; as mensagens aprendidas dos conteúdos perpassados nas tramas diversas - o currículo oculto.

Essa comparação não pretende simplificar a análise ou formatar esses níveis curriculares em compartimentos estanques. É apenas uma aproximação entre contextos de aprendizagens diferentes, partindo de um já consensual - a escola - para outro ainda polêmico - os games - com o intuito de ressaltar este último como ambiente educativo e veiculador das relações de gênero, em que meninos e meninas correspondem a "estabelecidos e outsiders" (MOITA, 2007c, p.29), respectivamente.

De acordo com Gadotti (2000), para se pensar a educação do futuro, é preciso considerar as possibilidades de novos espaços de formação. Assim, é necessário admitir que "o ciberespaço rompeu com a idéia de tempo próprio para a aprendizagem. [...], o espaço da aprendizagem é aqui - em qualquer lugar -, e o tempo de aprender é sempre" (GADOTTI, 2000, p. 250).

Com base nesse pensamento, propomos uma análise dos games como elementos significativos da formação de conceitos em gênero, numa visão otimista da educação e do seu entrelaçamento com tais contextos curriculares contemporâneos, em contraposição às opiniões discriminatórias e desanimadoras sobre o aproveitamento pedagógico de um recurso vivo, entre crianças e jovens. 
Ao apresentar os games como espaços de formação, é necessário recorrer aos estudos de Certeau (2005), quando estabelece as distinções entre lugar e espaço:

Um lugar é a ordem (seja qual for) segundo a qual se distribuem elementos nas relações de coexistência. Aí se acha portanto excluída a possibilidade, para duas coisas, de ocuparem o mesmo lugar [...] Implica uma indicação de estabilidade.

[...] Existe espaço sempre que se tomam em conta vetores de direção, quantidade de velocidade e a variável tempo. O espaço é um cruzamento de móveis. É de certo modo animado pelo conjunto de movimentos que aí se desdobram. É o efeito produzido pelas operações que o orientam, o circunstanciam. O temporalizam e o levam a funcionar em unidade polivalente de programas conflituais ou de proximidades contratuais. [...] Em suma, $o$ espaço é um lugar praticado. (CERTEAU, 2005, p.201-202, grifo do autor)

Nessa perspectiva, os games, por suas condições de interatividade, como lugares visitados, podem ser considerados espaços, adjetivados como educativos que, de fato, fazem parte da vida das crianças e dos jovens, predominantemente, contudo, também consumidos pelo público adulto em menor, mas, ascendente escala.

A partir da tipologia básica, os games podem ser classificados em simuladores, jogos de estratégia e jogos de ação, assim explicados por Kensky (2007, p. 117):

Os simuladores exigem reflexos e movimentos rápidos para, por exemplo, pilotar carros velozes em corridas e ralis ou esquiar 
em perigosas curvas de pistas de neve. Já os jogos de estratégia precisam de raciocínio, para construir e administrar uma cidade ou para conduzir exércitos e vencer uma guerra. Os jogos de ação são aqueles em que o jogador encarna um personagem no cenário do jogo e comanda ações, em geral com movimentos rápidos.

Podemos depreender, então, que, nas três tipologias descritas, ocorre a estimulação ao desenvolvimento de habilidades necessárias à sobrevivência na vida real, com suas peculiaridades, inclusive exigidas no mundo adulto, conforme a área de atuação profissional, das funções psicológicas superiores (VYGOTSKY, 2007).

Mesmo assim, para muitos, as atividades com games são vistas como prejudiciais ou negativas para a socialização e a aprendizagem. Na contramão dessas generalizações, aqui se ressaltam os ganhos proporcionados pelo uso de tais atividades, ressaltadas como oportunidades de educação, construção e reconstrução de valores e conceitos, enfim, de formação sociocultural:

O jogo é um elemento da cultura que contribui para o desenvolvimento social, cognitivo e afetivo dos sujeitos, se constituindo assim, em uma atividade universal, com características singulares que permitem a ressignificação de diferentes conceitos. Portanto, os diferentes jogos e em especial os jogos eletrônicos, podem ser denominados como tecnologias intelectuais (ALVES, 2007, p. 63).

Não há dúvidas de que os/as estudantes de agora são diferentes daqueles de antes, que não tiveram contato com as novas tecnologias e não experimentaram conhecimentos novos, como a interatividade e a liberdade de escolha. A geração que somente lia 
os livros estáticos não têm a mesma desenvoltura intelectual da geração que procede à leitura dos games que exigem disposição para desafios difíceis de vencer, além de ensinar conceitos complexos.

De acordo com Johnson, as "virtudes dos jogos vão muito além da coordenação visual e motora” (JOHNSON, 2005, p.20), pois mais importante do que, "o que se pensa enquanto se está jogando é o modo como se pensa” (JOHNSON, 2005, p.33). Os games assumem a função de dispositivo mobilizador do cérebro para a tomada de decisões, baseadas em duas modalidades de trabalho intelectual: "sondagem e investigação telescópica" (JOHNSON, 2005, p.35, grifo do autor).

A sondagem estimulada e exercitada nos games, em linhas gerais, vai além de uma olhada superficial, constituindo-se em verdadeiras expedições investigativas, sob atenção consciente, com uso de procedimentos básicos do método científico, como: exploração, suposição, testagem, conclusão ou refutação da hipótese original.

A investigação telescópica refere-se ao gerenciamento da jornada de concentração ativa na resolução de problemas e dos objetivos que devem ser alcançados, ressaltando suas sequências hierárquicas mentalmente organizadas e os impulsos para realizar multitarefas e suas respectivas habilidades.

Com efeito, Johnson apresenta argumentos consistentes das vantagens intelectuais de se praticar com games e remete educadores e educadoras curiosos/as aos emergentes estudos da neurociência, que propõem a concretização de atualizações cognitivas bem mais eficazes, através dos games, do que as emitidas pelo meio escolar, que estariam em déficit, para os cérebros que convivem com os estímulos das novas formas de mídia e das tecnologias digitais. 
Os estudos de Moita nos apresentam os games como currículos pertinentes ao contexto curricular juvenil, no qual é oportunizado e estimulado o desenvolvimento de habilidades como "perspicácia e velocidade de raciocínio", além de outras que "ajudam os jogadores a interagirem mais rapidamente com o establishment cultural e social" (MOITA, 2007c, p.180-181).

\section{0 contexto pedagógico do "The Sims 2"}

No estudo ora apresentado, contamos com a colaboração de uma jogadora, doravante denominada jogadora-colaboradora, que aceitou o convite para tornar-se elo focal. A adolescente, de treze anos (J.B.P.F.), contribuiu para a primeira exploração pedagógica do contexto do "The Sims 2".

O “The Sims 2", lançado em 2004, faz parte de uma série de jogos eletrônicos lançada em 2000, classificada na categoria de simulação, totalmente tridimensional, cuja trama se desenrola, predominantemente, em um cenário doméstico, como nos mostra a figura 1 (abaixo), com expansões opcionais ${ }^{14}$, embora conduza o/a jogador/a a situar-se em um contexto social mais amplo, assumindo as consequências de suas atitudes. É possível conquistar a progressão por esforço, agilidade e administração financeira eficaz. Sendo assim, faz-se necessário organizar as responsabilidades da vida diária em curto e longo prazos, tendo a evolução cronológica como possibilidade de evolução e de novas conquistas.

14 O contexto do "The Sims 2" pode ser enriquecido com a aquisição das expansões que apresentam diversas situações como : "Vida de universitário"; "Vida noturna"; "Animais de estimação", dentre outras. 


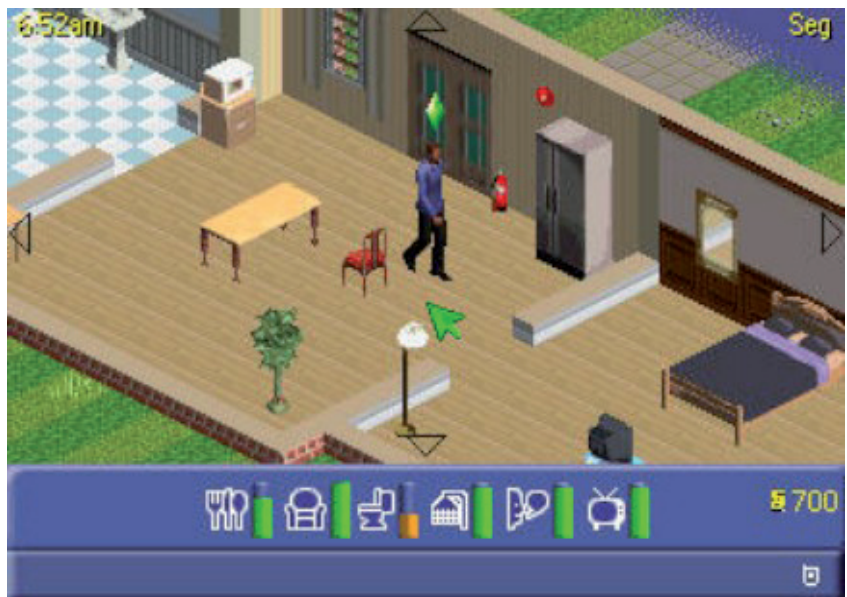

Figura 1- Reprodução do cenário básico do "The Sims"

O/a jogador/a pode traçar o perfil físico e psicológico dos seus $\mathrm{SIMS}^{15}$, fator que já proporciona a tomada de decisões e de escolhas pessoais refletidas, como aspecto principal a ser desenvolvido nos/nas jogadores/as que ainda devem estar atentos/as aos painéis "Desejos, Temores e Necessidades", para manter seus personagens em equilíbrio constante.

Nos painéis, encontramos itens como conforto, banheiro, energia, diversão, social, higiene e ambiente. Nesse sentido, o/a jogador/a deve manter tais níveis satisfatórios dos seus SIMS, articulando-os com as opções de ação: "Relacionamentos, forma física e interesses." Além dessas, existem obrigações inadiáveis, como estar bem na escola, cuidar da carreira profissional e fazer pagamento de contas, que aproximam a experiência lúdica das situações da vida real responsável.

15 São denominados SIMS os/as personagens criados/as e assumidos/as pelos/as jogadores/as no game em estudo, numa variação do clássico "avatar". 
Eleger prioridades e aprender a trabalhar com o próprio tempo, utilizando-o de forma adequada, além de se dispor a enfrentar desafios inesperados, são habilidades incentivadas pelo game, corroboradas pelas recompensas conquistadas sobre os acertos, de acordo com as tomadas de decisões. Portanto, a articulação favorável entre a convivência com regras e a liberdade de escolha favorece o SIM a progredir no game. Com relação à orientação sexual, consideramos o respeito pela diversidade sexual e de gênero: o SIM pode escolher se relacionar com o sexo oposto ou com o mesmo sexo; se terá filhos ou não; se casará ou não.

Caso resolva constituir uma família, o/a jogador/a deverá atentar para os cuidados com a mesma e decidir "por afinidade" quem ficará mais tempo em casa ou fora, quem cuidará das crianças e da casa, podendo distribuir as tarefas independentemente dos estereótipos de mulher, no espaço privado e homem, no espaço público, pois não há obstáculos sobre essas determinações que até podem ser variadas em sistema de rodízio ou mesmo seguir um rumo menos comum.

A jogadora colaboradora, por exemplo, constituiu uma família na qual a mulher/mãe tinha menos tempo em casa com os filhos por se preocupar mais com a carreira profissional, enquanto o homem/ pai se identificava melhor com as questões familiares e domésticas com as quais era mais envolvido.

Por ser um simulador e não ter regras predeterminadas sobre as escolhas dos/as personagens, esse game não adota pressupostos da ordem androcêntrica fundante das desigualdades de gênero (BOURDIEU, 2005b), permite deslocamentos de padrões estereotipados e possibilita o exercício do livre arbítrio, ao desconstruir a heterossexualidade compulsória (LOURO, 2000) e fornecer o cenário doméstico em conexões com o mundo exterior para ambos os sexos. Nesse universo, é possível exercitar a construção de novas identidades, livres das imposições dos habitus opostos para meninos e meninas (BOURDIEU, 2005b). 
O desenvolvimento das habilidades de leitura e atenção é um requisito indispensável para a continuidade do jogo, pois todas as sinalizações de alerta e de avanço são propostas por textos, quase sempre, verbais, contudo ocorrem também textos não verbais que, da mesma forma ou até em maior proporção, exigem capacidade de interpretação do/a jogador/a. O vocabulário é enriquecido com alguns termos até então desconhecidos para jogadores/as, impulsionando-os/as à busca pelo conhecimento do novo e a ampliação de conhecimentos.

No game, o contexto favorável ao desenvolvimento da linguagem impulsiona as interações entre aprendizado e desenvolvimento da inteligência, e o papel do brinquedo, especialmente do faz-deconta, funciona como projeções do mundo adulto, promovendo a internalização das funções psicológicas superiores e o amadurecimento saudável das estruturas cognitivas (VYGOTSKY, 2007).

\section{Coleta e discussão dos dados: as aprendizagens no game}

Atualmente, a pesquisa qualitativa tende a ser percebida como um processo multicultural, numa perspectiva de antineuralidade. Essa abordagem em muito contribuiu para a constituição de uma nova maneira de fazer ciência, opondo-se ao quantitativismo dominante, e passou por ressignificações que a ampliaram para "um conjunto de práticas materiais e interpretativas que dão visibilidade ao mundo" (DENZIN; LINCOLN, 2006, p. 17).

Diante da necessidade de atenção à revisão de questões norteadoras, no desenvolvimento das ações investigativas e interpretativas na abordagem qualitativa, foram utilizados questionários, com o grupo, como instrumentos de coleta de dados, e entrevistas, com a jogadora-colaboradora, sendo esta última técnica iluminadora de alguns dados coletados pela citada anteriormente. A jogadora-colaboradora também auxiliou nos contatos com demais pesquisados e pesquisadas. 
A pesquisa seguiu os princípios da bricolagem onde, "os bricoleurs têm em conta a influência de 'estar no mundo' para eles próprios, para outros pesquisadores e para os fenômenos que se propõem a estudar", conforme Kincheloe e Berry (2007, p.11).

No total, os sujeitos pesquisados/as foram trinta e quatro adolescentes, sendo dezoito do sexo masculino e dezesseis do sexo feminino, estudantes do oitavo ano do Ensino Fundamental de uma escola privada de classe média alta de Campina Grande-PB, com faixa etária entre doze e quatorze anos, turma da qual faz parte a jogadora-colaboradora.

O acesso ao campo foi conquistado, através de contato pessoal e comunicação escrita com a Direção e a Coordenação de Escola, na qual foram explicados os objetivos da pesquisa além de apresentação prévia do questionário adaptado, aplicado e recolhido em sala de aula pelas pesquisadoras, quando da primeira aproximação empírica.

Em seguida, foi realizada uma entrevista não estruturada, focalizada, não-dirigida, (LAKATOS, 2007) com a jogadora-colaboradora, para auxiliar a interpretação dos dados coletados.

Dos/as pesquisados/as, apenas dois afirmaram não jogar: um adolescente e uma adolescente. Trinta e dois estudantes afirmaram que jogam em casa. Entre esses/as, onze jogam em casa de amigos/ as, oito, em lan-houses, um deles joga ao celular, e outro, em locadora. Embora não tenha sido alvo principal da pesquisa, a partir dessas constatações, foi possível conjecturar que o envolvimento com os games pode minimizar aproximações com maiores riscos de violência e proteger os /as jovens de diversões que coloquem em perigo suas vidas.

Sobre os estilos dos jogos, a maioria expressou que prefere os jogos de aventura, seguida dos de estratégia e ação, ficando em último lugar a escolha por jogos de luta. A lista solicitada dos quatro 
jogos, por ordem de preferência, citados por cada pesquisado/a, com respectivos motivos, teve a diversidade como a principal característica: cinquenta games diferentes foram indicados e justificados pelas mais diferentes opções. Destacaram-se pela quantidade de vezes que foram citados, como cinco primeiros colocados, os que aparecem na tabela 01 abaixo:

\begin{tabular}{c|c}
\hline Games preferidos & Quantidade de citações \\
\hline THE SIMS & 13 estudantes \\
\hline NEED FOR SPEED & 13 estudantes \\
\hline CONTER STRIKE & 09 estudantes \\
\hline GTA & 08 estudantes \\
\hline FUTEBOL & 07 estudantes \\
\hline
\end{tabular}

Tabela 1 - Games citados como preferidos por pesquisados/as

No demonstrativo acima, confirmamos a relevância da escolha pela evidência de que esse game faz parte do contexto de interesse dos sujeitos da pesquisa. Verificamos, ainda, que a citação do "The Sims" entre os games preferidos ocorreu por parte de dez meninas e apenas três meninos. Além dos treze estudantes que o citaram, mais sete afirmaram jogá-lo, embora não o tivessem incluído na sua relação de prioridades. Desses, seis meninos e uma menina. Totalizaram-se, assim, vinte jogadores/as, sendo nove meninos e onze meninas, conforme exposto na tabela 02, a seguir:

\begin{tabular}{c|c|c|c}
\hline Pesquisados/as & Jogam “The Sims" & Não jogam “The Sims" & Totais gerais \\
\hline Masculino & 09 (nove) & O9 (nove) & 18 (dezoito) \\
\hline Feminino & 11 (onze) & 05 (cinco) & 16 (dezesseis) \\
\hline Totais parciais & 20 (vinte) & 14 (catorze) & 34 (trinta e quatro) \\
\hline
\end{tabular}

Tabela 2 - Indicadores de sexo-gênero acerca do game "The Sims" 
Portanto, a princípio, há, nesse grupo, segmentação por gênero. Esse fator sinaliza que é preciso problematizar as questões de gênero e confirma, em parte, a segregação já percebida em outras situações pesquisadas acerca dos games (MOITA, 2007c, p.23).

Podemos analisar não somente a diferença absoluta encontrada entre o grupo masculino e o feminino que jogam o "The Sims", mas os números relativos aos totais, por sexo, o que confirma uma tendência para esse game no grupo feminino, enquanto que, no masculino, além de ocorrer uma divisão explícita em razão das metades entre jogar e não jogar, houve um dado qualitativo já exposto anteriormente e que, mais uma vez, merece reflexão: dos nove jogadores identificados, apenas três o citaram como entre os preferidos; já as jogadoras, dentre as onze que afirmaram jogar, dez delas o citaram entre os preferidos.

Os nove adolescentes (sexo masculino) que afirmaram não jogar o "The Sims" apresentaram justificativas como estas:

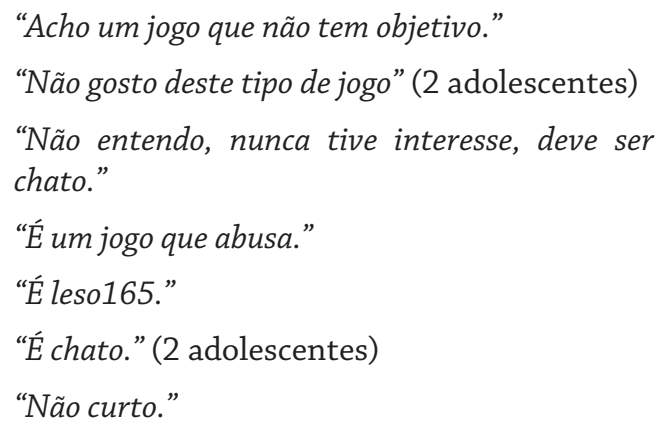

Um deles rasurou uma perceptível escrita de que o jogo era "de gay”, substituindo essa expressão por "ruim”. Foi visível, no grupo masculino, o desinteresse pelo jogo que retrata as responsabilidades

$16^{5}$ Expressão usada na forma coloquial da língua para designar algo bobo e sem propósito, nesta região. 
da vida real, dando destaque ao cenário doméstico e suas peculiaridades, como cuidar da casa e da família. Podemos estar testemunhando a construção efetiva de habitus opostos entre meninos e meninas (BOURDIEU, 2005b), em que o espaço privado e o público se contrapõem, sendo outorgadas às mulheres as tarefas do primeiro, enquanto aos homens são atribuídas as ações relativas ao segundo espaço. Contudo, os motivos alegados pelas jogadoras para jogar o The Sims se referem, predominantemente, às suas características de simulação e de aproximação com a vida real, como mostram estas justificativas apresentadas pelas jogadoras:

"Porque é realista"

"É um jogo que mexe como se fosse realidade, uma experiência de vida."

"Atiça muito minha esperteza e agilidade com diversas situações"

"É um jogo em que a pessoa se sente dentro dele."

"Acho muito criativo. Parece que estamos na vida real."

"É um ótimo jogo de estratégia."

Na opinião dos jogadores, temos estas falas:

"É um bom jogo para os jovens perceberem como a vida é dificil"

"É interessante, às vezesé engraçado e desenvolve muito o raciocínio lógico, pois tem a capacidade de escolha."

"Dá uma idéia de como poderia ser cuidar de uma família, pois cada personagem tem um gosto $e$ uma necessidade." 
Considerando-se os motivos apresentados acima pelo grupo que joga o "The Sims", percebemos que as possibilidades de aprimoramento social e cognitivo não são ignoradas pelos/as jogadores/ as, e que o game os remete à vida real. Podemos estar consolidando as preocupações femininas sobre o cenário doméstico, desde a adolescência, talvez por experiências familiares vivenciadas nessa direção, embora as mulheres estejam inseridas no mercado de trabalho, assumindo a dupla jornada: pública e privada. Todavia, é animador o fato de os jogadores manifestarem o interesse em aprender a cuidar de uma família.

Portanto, poderíamos aqui discutir a evidência de que tal missão não faz parte da "vida real" dos jogadores, como afirmado pelas jogadoras, e de que, ao afirmar que o jogo oferece oportunidades de "saber como a vida é difícil", eles podem estar considerando o distanciamento das tarefas domésticas do universo masculino, disponíveis para serem experienciadas a partir do jogo.

$\mathrm{Na}$ sequência, a jogadora-colaboradora aplicou um segundo questionário, com perguntas abertas, com uma amostra voluntária de alunos/as da turma, de oito jogadores/as do "The Sims 2", sendo quatro jogadores e quatro jogadoras. Esta nova coleta ocorreu para que aprofundássemos as análises, a partir de opiniões sobre as habilidades que poderiam ser desenvolvidas e de mensagens aprendidas no game em estudo, já evidenciadas na primeira recolha de dados, porém superficialmente.

Dentre as respostas obtidas, destacaram-se:

"A habilidade de atenção e de tratar bem as pessoas." (fem.)

"A habilidade de viver; o que faria se fosse adulto." (fem.)

"Aprender a administrar seu próprio dinheiro e ter responsabilidades." (fem./masc.) 
"Aprender a cuidar de uma família." (masc.)

"Aprender a conviver com as pessoas."

(fem./masc.)

"Aprender como construir as coisas." (masc.)

Nesse segundo momento, ambos os sexos se referem às preocupações com estratégias de sobrevivência, de administração financeira, com a importância de se relacionar bem com as outras pessoas, e os jogadores se referiram em maior número à aprendizagem sobre os cuidados com a família, enquanto as jogadoras evidenciaram explicações mais voltadas para as características realistas e estratégicas do game.

Ao ser analisado o teor das justificativas apresentadas sobre as habilidades possíveis de serem desenvolvidas no jogo "The Sims 2", é notório o entrecruzamento das subjetividades de jogadores e jogadoras adolescentes, possibilitando o questionamento e a desconstrução de visões estereotipadas dos gêneros masculino e feminino, como também o delineamento de novos perfis mais flexíveis e plurais para um próximo mundo adulto.

Podemos depreender que, a partir das simulações e das interações realizadas, surgem experiências virtuais de equidade e de respeito à diversidade de gênero, que contribuem para a formação de identidades mais autorizadas e habitus menos dicotômicos entre o masculino e o feminino, possíveis no mundo real, uma vez que ser realista é uma das características do "The Sims 2", de acordo com os/as próprios/as jogadores/as.

É significativo ressaltar a constância do termo "aprender" empregado por parte dos/as jovens entrevistados/as, demonstrando suas percepções dos jogos como espaços de efetivas aprendizagens e experiências válidas, além das sinalizações das noções de ética e de moral, extremamente necessárias e escassas como práticas de vida entre os/as adultos/as contemporâneos/as. A utilização das 
habilidades cognitivas e sociais, como elementos significativos em favor da aprendizagem, em muito poderá ajudar a tornar o processo de ensino escolar efetivo, gratificante e saudável para todos/ as os/as envolvidos/as e para a sociedade como um todo.

Por último, foi realizada outra entrevista da mesma tipologia supracitada com a jogadora-colaboradora, para que ela expressasse seus sentimentos sobre o jogo em foco, embora, nesse momento, já revelasse interesses por outros jogos, como o GTA. Dessa situação, transcrevemos o fragmento a seguir:

O THE SIMS 2 é um jogo que mexe com a realidade. Cada personagem que fazemos é como se fôssemos nós mesmos, atendendo às nossas necessidades: sustentando a casa, cuidando de filhos, trabalhando, até mesmo indo à escola, tendo que cumprir notas e sempre estar melhorando as habilidades dos personagens para serem promovidos no emprego e em outras coisas mais. É tão real que os SIMS envelhecem, passam a ganhar aposentadoria, seu humor muda, tudo de acordo com a idade. E quem está do outro lado da tela se concentra nas necessidades que cada um tem: fome, banheiro, social, etc.; visando sempre alcançar o topo seja na profissão, como boa mãe, bom pai e esposa ou marido. (J.B.P.F.)

A jogadora-colaboradora citou um dado até então não percebido pelas questões anteriores: o preparo para o envelhecimento e a compreensão entre as gerações pode ser também uma aprendizagem exercitada no contexto pedagógico do "The Sims 2". Assim, não nos restam dúvidas de que os games se constituem um dos principais cenários em "que crianças e jovens estão cada vez mais construindo suas percepções de mundo, suas identidades e suas subjetividades." (MOITA, 2007b, p.146) 


\section{Conclusões}

Esta pesquisa nos indicou que as construções de gênero veiculadas pelo "The Sims 2" proporcionam um universo de diversidade, em que homens e mulheres (SIMS masculinos e femininos) assumem responsabilidades familiares e profissionais na mesma medida, e personagens compartilham das mesmas necessidades, dificuldades e possibilidades. Esse game oferece oportunidades para que os jogadores se envolvam com a trama doméstica, aprendendo a cuidar da família que criaram, da mesma forma que as jogadoras são estimuladas a ascenderem profissionalmente e vice-versa.

Com efeito, esse game pode ser um espaço educativo favorável à construção de relações de gênero pautadas no respeito, em contraposição aos perversos estereótipos construídos e perpetuados historicamente.

Confirmamos, pois, que as atividades com games, seguramente, não se constituem em perda de tempo, como consideram, ainda, muitas pessoas, que não procuraram compreender as vantagens decorrentes dessa ocupação, mas apresentam consequências positivas, que poderão beneficiar os/as envolvidos diretos/as, os/as jovens jogadores/as, suas famílias, a escola e a sociedade em geral.

Tais vantagens apenas se iniciam no fato de que os/as jovens que assumem a prática com games permanecem mais tempo no seu lar e em casa de amigos, o que diminui, consideravelmente, a probabilidade de se envolverem em problemas urbanos, como a violência e o uso de drogas, trazendo ganhos emocionais, sociais e econômicos para as estruturas familiares e os contextos gerais da sociedade.

O desenvolvimento da leitura, a atenção, a investigação, a tomada de decisões, o raciocínio lógico e a comunicabilidade, dentre outras capacidades cognitivas tão reclamadas pela escola, foram 
enunciados pelos/as pesquisadas, com base em seus relatos de experiências com o game estudado. Tais habilidades, já evidenciadas pelas pesquisadoras como necessárias por ocasião da primeira aproximação emprírica ao "The Sims 2", conforme descrito sobre o contexto pedagógico do game, foram confirmadas de forma recorrente pelos/as adolescentes jogadores/as, como também as oportunidades de aprender a viver e a conviver, a se cuidar melhor, a saber construir e a lidar com dificuldades.

O “The Sims 2" revela-se, pois, como um currículo extraescolar, que pode oferecer um alicerce/suporte para futuras aprendizagens escolares "ao simular cenários do 'mundo real', poderão permitir uma maior generalização das tarefas para a vida diária" (MOITA, 2007a, p. 46), figurando como ponte que nos remete promissoramente aos desafios dos quatro pilares imputados à educação do Séc. XXI: aprender a ser, aprender a fazer, aprender a viver juntos e aprender a conhecer (DELORS, 1998).

Cabe, pois, às escolas e aos/às educadores/as buscarem maneiras de conhecer melhor e rever os conceitos sobre os games, para aproveitá-los como experiências educativas ou credenciar em seus currículos as habilidades intelectuais estimuladas e desenvolvidas através dos games, quase sempre, desprezadas e ignoradas pela formalidade educacional, frequentemente criticadas de forma generalizada e preconceituosa por parte das instituições de ensino e de seus/suas agentes.

Enfim, como educadores e educadoras, precisamos, urgentemente, atentar para as experiências com os games como áreas de pesquisas educacionais e valorizá-los como currículo efetivo, como terreno propício à produção cultural para a ressignificação das concepções de gênero, como oportunidade de estimulação cognitiva e de desenvolvimento da inteligência ( JOHNSON, 2005), incluindo-os nas agendas da Pesquisa em Educação e no Currículo Escolar. 


\section{Referências}

ALVES, L. Jogos eletrônicos e SCREENAGENS: possibilidades de desenvolvimento e aprendizagem. In: SILVA, Eliane M.; MOITA, Filomena; SOUSA, Robson P. Jogos eletrônicos: construindo novas trilhas. Campina Grande: EDUEP, 2007.

BERTRAND, Y.; VALOIS, P. Paradigmas educacionais: escola e sociedades. Lisboa: Instituto Piaget, 1999.

BOURDIEU, P. 0 poder simbólico. 8. ed. Rio de Janeiro: Bertrand Brasil, 2005a.

A dominação masculina. 4. ed. Rio de Janeiro: Bertrand Brasil, $2005 b$.

BRANDÃO, Zaia. Pesquisa em Educação: conversas com pós-graduandos. Rio de Janeiro: PUC-Rio; São Paulo: Loyola, 2002.

BRASIL. Diretrizes Curriculares Nacionais para o Ensino Fundamental. Parecer CEB 04/98. Aprovado em 29/01/1998. Disponível em: <http://portal.mec.gov.br/cne/arquivos/pdf/1998/ pceb004_98.pdf>. Acesso em: 22 out. 2010.

CASTELLS, M. O fim do patriarcalismo: movimentos sociais, família e sexualidade na era da informação. In: 0 poder da identidade . São Paulo: Paz e Terra, 2002. (A era da informação: economia, sociedade e cultura, 2).

CERTEAU, M de. A invenção do cotidiano: artes de fazer. 11ed. Petrópolis, RJ: Vozes, 2005.

DELORS, J.(Coord.). Educação: um tesouro a descobrir. Brasília: UNESCO, 1998.

DENZIN, N K. \& LINCOLN, Y. S. O planejamento da pesquisa qualitativa: teorias e abordagens. Porto Alegre: Artmed, 2006. 
FREIRE, P. Pedagogia do oprimido. 25. ed. Rio de Janeiro: Paz e Terra, 1987.

GADOTTI, M. Perspectivas atuais da educação. Porto alegre: ARTMED, 2000.

JOHNSON, S. Surpreendente! A televisão e o vídeogame nos tornam mais inteligentes. Rio de Janeiro: Campus/Elsevier, 2005.

KENSKI, V. M. Educação e tecnologias: o novo ritmo da informação. Campinas, SP: Papirus, 2007.

KINCHOLOE, J. L; BERRY, K. S. Pesquisa em educação: conceituando a bricolagem. Porto Alegre: Artmed, 2007.

LAKATOS, E. M.; MARCONI, M. de A. Técnicas de pesquisa: planejamento e execução de pesquisas, amostragens e técnicas de pesquisas, elaboração, análise e interpretação de dados. 6. ed. São Paulo: Atlas, 2007.

LIBÂNEO, J. C. Didática. São Paulo: Cortez, 1994.

LOURO, G. L. Gênero, sexualidade e educação: uma perspectiva pósestruturalista. 7. ed. Petrópolis: Vozes, 2004.

.Currículo, gênero e sexualidade. Portugal: Porto, 2000.

MOITA, F. M. G. da S. C. Os GAMES: contextos de aprendizagem colaborativa on line. In: ; SILVA, Eliane Moura; SOUSA, Robson Pequeno. Jogos eletrônicos: construindo novas trilhas. Campina Grande: EDUEP, 2007.

MOITA, F. M. G. da S. C. Game On: jogos eletrônicos na escola e na vida da geração@. Campinas: Alínea, 2007.

VYGOTSKY, L. S. A formação social da mente: o desenvolvimento dos processos psicológicos superiores. 7. ed. São Paulo: Martins Fontes, 2007. 



\section{A tecnologia e 0 ensino de química: jogos digitais como interface metodológica}

\section{Érika Rossana Passos de Oliveira Lima}

UEPB - Campina Grande, Paraíba erikarossanapol@hotmail.com

\section{Filomena Ma Gonçalves da Silva Cordeiro Moita}

UEPB - Campina Grande, Paraíba

filomena_moita@hotmail.com

A partir dos impactos provocados pela rápida evolução tecnológica, vêm-se estabelecendo e implantando diversas formas de ensino, apoiadas em um conjunto diversificado de recursos que favorecem a utilização da multimídia no processo de ensino e aprendizagem, embasadas pelas tecnologias.

Nesse contexto, um dos enfoques se refere à utilização dessas tecnologias como uma ferramenta didática, como por exemplo, o jogo digital, um recurso tecnológico lúdico, que agrega fatores como: diversão, prazer, habilidades e conhecimentos. Considerando-se as possibilidades de utilização e de direcionamentos que esse recurso oferece, sua inserção na ciência química no meio didático configura-se como um recurso eficaz, possibilitando o aumento e a motivação dos alunos, ao passo que disponibiliza atividades 
diversas e atrativas, constituindo-se como um instrumento multifacetado que favorece o aprender e/ou resolver problemas, através da interação com o saber.

“A utilização do jogo no campo do ensino e da aprendizagem proporciona condições para maximizar a construção do conhecimento, introduzindo as propriedades do lúdico, do prazer, da capacidade de iniciação e ação ativa e motivadora" (KISHIMOTO, 1999, p.37). Metodologias que façam uso de jogos despertam o aluno para a aprendizagem dos conteúdos escolares, tendo por via um recurso tecnológico atrativo e prazeroso para o desenvolvimento de habilidades cognitivas.

Tendo em vista criar um diferencial didático-pedagógico, através de um direcionamento metodológico inovador, utilizamos o jogo adivinhas ${ }^{17}$ da tabela periódica, que aborda as propriedades e características dos elementos químicos, bem como a sua presença no cotidiano e a estrutura da tabela. Nesse sentido, este artigo tem como objetivo abordar a importância do jogo digital adivinhas, da tabela periódica, e sua contribuição para o ensino de Química.

\section{A tecnologia no ensino da ciência química}

A ciência química é uma forte aliada para a essência da vida, tornando-se uma das responsáveis direta pelo aumento da expectativa de vida do homem moderno. O reconhecimento da projeção e da importância chega aos meios de comunicação e informação e aos fins educacionais. Essa realidade faz com que surjam inovações em

$17 \mathrm{O}$ jogo digital advinhas da tabela periódica encontra-se no site: http://nautilus. fis.uc.pt/cec/jogostp/jogos/adivinhas/index.html. Aborda os elementos químicos diante de suas propriedades e características, a estruturada da tabela periódica e a presença dos elementos no cotidiano. 
todos os segmentos sociais e no planejamento escolar, que aponta novos e modernos rumos voltados para uma nova forma de ensinar química.

As novas tecnologias fornecem instrumentos imprescindíveis para essa empreitada, pois os recursos que elas disponibilizam são capazes de facilitar e agilizar a vida da sociedade contemporânea e de fornecer formação educacional, no campo da química, permitindo, assim, a atualização de conhecimentos, a socialização de experiências e a aprendizagem através dos recursos tecnológicos.

As novas tecnologias de informação e comunicação, caracterizadas como midiáticas, são, portanto, mais do que simples suportes. Elas interferem em nosso modo de pensar, sentir, agir, de nos relacionarmos socialmente e adquirirmos conhecimentos. Criam uma nova cultura e um novo modelo de sociedade (KENSKI, 2004, p. 23).

A abordagem acima apresenta o desenvolvimento de novas formas de interação cultural, de mediação escolar, consolidando que a tecnologia se configura como uma "caixa de ferramentas" úteis à elaboração e à ampliação de conhecimentos que favorecem procedimentos pedagógicos voltados à realidade, propiciando a interação dos alunos com o meio tecnológico.

Para que a parceria entre a tecnologia e o ensino de química seja auspiciosa, é preciso direcionar o fazer educativo de forma que o conhecimento/saber seja significativo e útil para os discentes, através de uma educação cujo processo de ensino e aprendizagem atinja o objetivo almejado.

Hoje, a química que nos circunda tem seus fundamentos negligenciados ao ser ensinada na escola, porquanto, não raras vezes, é trabalhada superficialmente, desconsiderando-se toda a sua 
abrangência. Porém, se sua implantação for planejada, pode propiciar um conjunto de práticas preestabelecidas que têm o propósito de contribuir para que os alunos se apropriem de conteúdos sociais e culturais de maneira crítica e construtiva.
[...] é preciso objetivar um ensino de Química que possa contribuir para uma visão mais ampla do conhecimento, que possibilite melhor compreensão do mundo físico e para a construção da cidadania, colocando em pauta, na sala de aula, conhecimentos socialmente relevantes, que façam sentido e possam se integrar a vida do aluno. (BRASIL, 1999, p.68).

Portanto, uma das formas de se promover um ensino de qualidade é através do emprego de tecnologias que se apresentem como uma ferramenta pedagógica que propicie a integração do aluno no mundo digital, através da otimização dos recursos disponíveis, possibilitando uma multiplicidade de formas de acesso ao conhecimento, de forma dinâmica, autônoma, prazerosa e atual.

A integração das tecnologias ao processo ensino e aprendizagem, mediante a utilização dos meios de comunicação e interação, com abordagem didática, pode favorecer a aprendizagem e o desenvolvimento dos alunos via inserção digital. Para a Kenski (2004):

As mídias há muito tempo abandonaram suas características de mero suporte tecnológico e criaram suas próprias lógicas, suas linguagem e maneira particulares de comunicar-se com as capacidades perceptivas, emocionais, cognitivas, intuitivas e comunicativas das pessoas (KENSKI, 2004, p.22). 
Com base nesse pensamento da autora, a amplitude e a aplicabilidade dos recursos mídiaticos na educação proporcionam aos docentes a construção de didáticas inovadoras, facilitando o desenvolvimento de competências e habilidades dos discentes, considerando que muitos desses recursos fazem parte do seu meio sociocultural. Essa constatação impõe que se repense a necessidade de implantar as novas tecnologias no meio escolar, como uma ferramenta didática interativa e significativa para o processo de ensino e aprendizagem.

A adoção dos recursos tecnológicos na prática educativa da disciplina de química requer um planejamento, cuja metodologia esteja centrada na realidade da vida e no social. Destarte, a metodologia empregada pelo professor terá por meta envolver o aluno no estudo da química, por meio da análise e da elucidação dos fenômenos do mundo natural e virtual com as quais apreenderão os contornos das questões socioambientais. Nesse sentido, a educação cumprirá sua função social, uma vez que o ensino proposto não se limita à mera "transmissão" dos conteúdos e das abordagens tratados pela disciplina. A aprendizagem será desenvolvida através de uma postura metodológica que se insere na vida dos alunos e os liga ao contexto tecnológico.

Um novo tempo, um novo espaço e outras maneiras de pensar e fazer educação são exigidos na sociedade da informação. $\mathrm{O}$ amplo acesso e o amplo uso das novas tecnologias condicionam a reorganização dos currículos, dos modos de gestão e das metodologias utilizadas na prática educacional (KENSKI, 2004, p.92).

Faz-se, pois, necessário que o professor conheça as novas tecnologias e como elas podem melhorar a sua práxis. Atualmente, o trabalho do professor não consiste simplesmente em transmitir 
informações ou conhecimentos, mas em apresentá-los de forma inovadora e estimulante, com o propósito de que a aprendizagem, através do uso da tecnologia, possibilite um fazer educacional, em que sejam trabalhados os conteúdos de forma interativa e lúdica, tendo como eixo norteador o contexto sócio-político-cultural no qual o aluno está inserido. Dessa forma, ele deixará de ser objeto do processo de ensino e aprendizagem e passa a ser o sujeito, o que o ajudará a desenvolver o senso crítico.

Um professor de biologia ou de química pode, hoje, substituir uma parte das experiências de laboratório - que continuam formativas por outras razões - através das operações virtuais que tornam muito menos tempo e, portanto, densificam as aprendizagens, porque é possível multiplicar as tentativas e os erros, sabendo imediatamente os resultados, e modificar as estratégias de acordo com a necessidade. (PERRENOUD, 2000, p. 133)

Reiteramos a afirmação do autor, pois, no contexto atual, é preciso que o professor use metodologias, procedimentos e programas educativos personalizados, a fim de desenvolver melhorias no processo de ensino e aprendizagem. Convém, no entanto, enfatizar que essa metodologia deve ser planejada, concatenada com os conteúdos curriculares da disciplina, na perspectiva de desenvolver as competências almejadas. A utilização das ferramentas tecnológicas, no ensino de química, devem explicitar seu caráter dinâmico, a fim de que o conhecimento químico seja expandido, não como um conjunto de conhecimentos isolados, prontos e acabados, mas como um conjunto de ensinamentos interativos que envolvem a interdisciplinaridade, a contextualização e a tecnologia, possibilitando a construção de conhecimentos voltados para a vida. 
Para esses fins, os ambientes de aprendizagem tecnológica devem estar centrados numa infinidade de recursos metodológicos que demonstrem o potencial do processo de produção do conhecimento. Entre esses recursos, podemos colocar também como fonte metodológica os jogos digitais, que estão vencendo o consenso subliminar de que são infrutíferos e nocivos, e ascendendo como objetos de estudo, representando uma alternativa didática e lúdica fundamental ao processo de ensino e aprendizagem.

\section{0 jogo digital como metodologia inovadora para 0 ensino de química}

O contexto tecnológico tem centrado suas dimensões e direcionamentos no âmbito educacional dos jogos digitais que vêm se firmando e se destacando como uma ferramenta frutífera, vencendo preconceitos e se solidificando no universo de potencialidades para o compartilhamento de saberes, de uma forma bem mais espontânea e participativa, em busca de olhar para a iminência que essa nova mídia pode trazer, ou seja, atentar para a aprendizagem que vai além do conteúdo explícito da experiência; intitulada de aprendizagem colateral (JOHNSON, 2005).

Com o advento das tecnologias, as sociedades e, principalmente, as massas, estão exigindo produtos e serviços cada vez mais eficientes, sofisticados e de qualidade. Essas mudanças atingem a todos, indistintamente, e em todos os aspectos da vida humana. Por isso, a escola está aberta às transformações e às inovações técnico-científicas, considerando que os mecanismos tecnológicos podem ser instrumentos didático-pedagógicos promotores de aprendizagem, possibilitando a construção de conhecimentos e o desenvolvimento de competências e habilidades. Os jogos digitais devem ser orientados de forma a estimular os discentes ao encontro e à construção do conhecimento como uma conquista, que os levam a superar limites e a enfrentar desafios. Isso permitirá o desenvolvimento das habilidades 
diversas, entre elas, a visomotora que, segundo Johnson (2005), proporcionará:

a) A busca, presente quando o jogador deseja avançar no game para, por exemplo, ver a narrativa do jogo concluída, ou mesmo o desejo de ver a próxima cena, o próximo desafio;

b) A sondagem, que diz respeito ao fato de o gamer não conhecer, a priori, o que deve fazer quando inicia o jogo, sendo necessário sondar, investigar o ambiente, para encontrar seus objetivos e as maneiras de cumpri-los, ou seja, entender as regras implícitas do jogo;

c) A investigação telescópica, que se relaciona à necessidade de o gamer ter que lidar com vários objetivos concomitantemente (os objetivos secundários ou imediatos e o objetivo principal do jogo).

No entanto, a teoria de Johnson coloca a mídia e a tecnologia, especialmente, os videogames, como ambientes que criam "maiores demandas cognitivas, mais profundidade, mais participação", que propiciaram os ganhos das últimas gerações em algumas formas de inteligência (JOHNSON, 2005, p. 127).

A associação dos jogos digitais aos conteúdos escolares, especificamente, aos conceitos da química, favorecem a aprendizagem mediante a utilização de uma metodologia que envolve a tecnologia e a influência da química na sociedade tecnológica moderna. Nesse caso, o jogo digital deve ser trabalhado com base nos jogos comerciais ou jogos educativos, desde que ele seja útil para o meio didático e que cause inovações, mudança de hábitos e inclusão digital. Na brincadeira com os jogos digitais introduzidos e orientados no conteúdo de química, no assunto tabela periódica, com o propósito de gerar conhecimento, cabe ao professor analisar e fazer do aprender uma atividade prazerosa e divertida, permitindo que o aprendente - jogador - torne-se mais ativo, ágil e crítico. 
A possibilidade de criar caminhos e cenários inexistentes, nos quais o jogador utiliza os conteúdos que permeiam seu imaginário para construir narrativas que não estão predefinidas, caracteriza a interatividade, o que potencializa a imersão em um universo de histórias em que o player ocupa o papel de interator (ALVES, 2005, p. 66).

A parceria da escola com esse indicativo deve ser trabalhada em prol da implantação de uma didática mais interativa, divertida. Para isso, é preciso ter uma visão mais crítica e realista, que considere os jogos digitais como instrumentos que podem beneficiar a educação. De acordo com Johnson (2001, p.15), "nossa memória visual é muito mais duradoura que a memória textual”. Então, mediante o comentário de Johnson, o jogo, além de trabalhar o visual, aguça nossa memória visual e contribui para a construção de conhecimentos, uma vez que eles fazem parte da vivência diária das pessoas e estão presentes nos mais diversos lugares, ou seja, em casa, nas lan houses, nos games, enfim, nos ambientes onde a maioria dos jovens buscam diversão.

Os jogos digitais podem beneficiar a educação, quando direcionados ao ensino das disciplinas e à ciência química, através do uso de metodologias que estimulem o interesse do aluno pelo estudo, concomitante com a diversão. Para que a aprendizagem torne o ambiente escolar atrativo para os jovens, a escola poderá explorar ludicamente os mais diversos campos do saber e gerar aprendizagem. É com essa visão que Perrenoud (2000, p.135) afirma: "Aqui se vê bem que a imaginação didática e a familiaridade pessoal com as tecnologias devem aliar-se a uma percepção lúdica dos riscos éticos".

Na utilização dos jogos digitais, com fins educacionais, devemos atentar para o fato de que sua aplicabilidade explora potencialidades e habilidades, mas a falta de domínio da tecnologia acarreta em riscos e descriminações. Logo, para incluí-lo no meio didático, é 
preciso, além do conhecimento e do domínio dos recursos tecnológicos, ter senso crítico, criatividade e planejar através de um estudo de credibilidade e avaliativo. Por exemplo, em um jogo aplicado na disciplina da ciência química, direcionado à poluição atmosférica e a impactos ambientais, esperamos que, no final, o aluno compreenda como se constituiu tal fenômeno e as substâncias interligadas, ou seja, possa entender melhor a obtenção do conhecimento da química, a mudança da vida dos seres vivos, devido aos impactos e sua contribuição para o desenvolvimento sustentável. Nesse sentido, pretendemos aprimorar e modernizar o processo metodológico, com o envolvimento tecnológico.

Para tanto, os jogos digitais podem ser direcionados para uma nova dinamicidade e inovação educacional, que possibilitam um estudo centrado num processo colaborativo e social, a partir do qual se desempenham ideias, formas de dialogar, compreender e aprender com esse suporte digital.

Os jogos digitais permitem que as metodologias sejam reelaboradas e reconstruídas, para propiciar maior interação entre alunos e professores, no decorrer do processo de ensino e aprendizagem, rompendo, assim, a limitação das relações professor-aluno e teoriaprática. Essa abertura dos espaços pedagógicos possibilita o contato entre o conhecimento aprendido na escola com o mundo. Assim, os jovens são instigados a buscar conhecimentos além dos que lhes são oferecidos na escola e que são encontrados nos espaços virtuais em que estão inseridos os jogos digitais, que se constituem como espaços produtores de conhecimento para o qual foram direcionados.

Para Lévy (2005, p. 132), "As comunidades virtuais parecem ser um excelente meio (entre centenas de outros) para socializar, quer suas finalidades sejam lúdicas, econômicas ou intelectuais, que seus centros de interesse sejam sérios, frívolos ou escandalosos". Portanto, o direcionamento se faz com a visão crítica e a percepção do professor em relação aos jogos digitais. Os games constituem-se espaços de rede colaborativa de partilha e de inovações e são uma 
interface educacional para as interações que desenham a flexibilização das aprendizagens e os modos de aprender colaborativamente e em rede (MOITA, 2006).

Nessa reflexão, os jogos digitais colaboram com o sistema de educacional pela inclusão de aprendizagem colaborativa e inovadora, que abre novos caminhos para a aquisição de conhecimentos. No entanto, essa aprendizagem deve estar fundamentada em uma análise prévia da mutação contemporânea, da relação com o saber e da adoção de um recurso tecnológico que favoreça o contexto educacional, porque a escola deve promover um conhecimento acerca da vida, permitindo que o aluno se posicione a respeito de questões sociais, ambientais, culturais. Logo, os jogos virtuais deverão ser trabalhados numa perspectiva crítica, para gerar conhecimento, mostrando aos educandos que o jogo pode estar presente no processo de ensino e aprendizagem e que se entrelaça com a sua realidade.

Assim, os jovens aprendem não só com o que lhes é diretamente ensinado, mas desenvolvem padrões de participantes nas práticas desenvolvidas em cada comunidade, neste caso, a comunidades dos games, o que inclui as práticas discursivas, o saber fazer e a utilização dos diferentes recursos. Os conhecimentos encontram-se, por isso, associados aos contextos que lhes dão sentido (MOITA, 2006 p. 18).

Em resumo, a escola, ao utilizar os jogos digitais, expande o conhecimento através do recurso tecnológico, permitindo uma formação global, que faculta aos discentes reagirem e lidarem com as principais mudanças sociais. Isso representa um desafio posto à educação do futuro, que precisa contribuir, substancialmente, através de abordagens, com técnicas e estratégias para o avanço e o desenvolvimento da produção do conhecimento. 
Além disso, a inserção dos recursos tecnológicos, no ambiente escolar, através da utilização do jogo digital, enquanto recurso didático para o ensino de química, dá condições para que o professor trabalhe com os alunos vários fatores, como o prazer de aprender brincando; diagnosticar criticamente a realidade; o conteúdo cognitivo e simbólico; a capacidade de memória; a coordenação visual e motora; a criatividade etc. Portanto, os jogos digitais, como instrumentos educativos, podem e devem ser introduzidos no ambiente escolar, desde que sejam direcionados à aquisição de conhecimentos de uma determinada área do saber.

\section{0 percurso: a prática dos jogos digitais no ensino de química}

Com a proposta de adequar e inovar a metodologia do ensino de química, através da utilização de recursos tecnológicos que promovem qualidade ao processo de ensino e aprendizagem, este trabalho utilizou os jogos digitais, como estratégia metodológica na disciplina da ciência química, a fim de apresentar o conteúdo tabela periódica para os alunos do $3^{\circ}$ ano do Ensino Médio, do Educandário Menino Jesus de Praga, no turno da manhã, no município de Esperança. A amostra foi composta por nove alunos dos sexos masculino e feminino, cuja faixa etária está compreendida entre 17 e 18 anos.

Destarte, a pesquisa desenvolveu-se em duas etapas, a saber:

- $1^{\text {a: }}$ O percurso metodológico foi iniciado com a ministração de aulões pré-vestibulares. $\mathrm{O}$ assunto estudado foi a tabela periódica; em seguida, realizamos uma atividade de montagem da tabela e, posteriormente, aplicamos um exercício escrito, com sete questões acerca do assunto. 
- $\quad 2^{\mathrm{a}}$ etapa: Direcionamos os alunos da amostra a uma lan house, a fim de que pudessem conhecer, aprender e brincar com o jogo digital advinhas' no qual a tabela periódica é trabalhada. Os alunos foram divididos em quatro grupos, de duas duplas e dois trios por computador; disponibilizamos o tempo de uma hora para que cada grupo jogasse e se divertisse. Foi considerado vencedor o grupo que primeiro conclui o jogo, o qual recebeu uma premiação simbólica. No final do jogo, foi aplicado um novo questionário semi-estruturado, com dez questões, com o intuito de obtermos dados que revelassem a percepção dos alunos acerca do conteúdo estudado. Os dados coletados com a aplicação de questionários e as observações realizadas no momento do jogo foram, posteriormente, analisados à luz da teoria que embasa este trabalho.

\section{Coleta e análise dos dados}

Após a aplicação do questionário e da análise dos dados, ficou constatado que os alunos entrevistados se enquadram na faixa etária entre 17 e 18 anos, 44\% dos alunos da amostra eram do sexo masculino, e 56\% deles, do sexo feminino, o que revela um equilíbrio entre os sexos e a faixa etária. Por uma questão de ética, não são apresentados nomes. Os alunos são identificados por letras. 


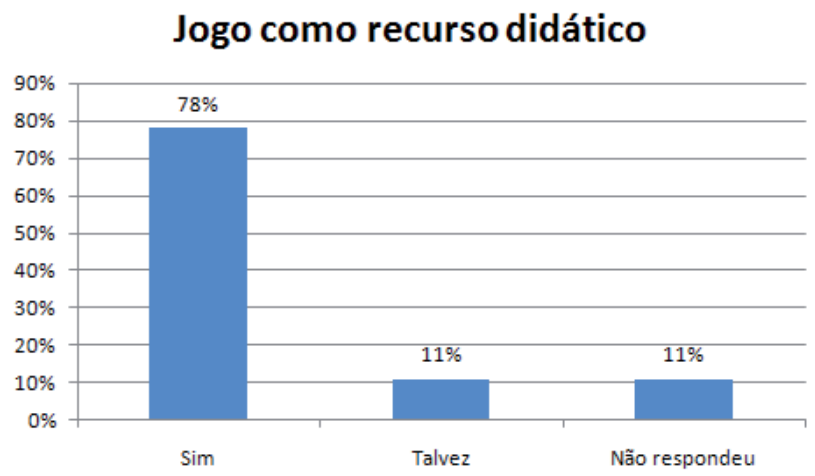

Gráfico 1 - O uso do jogo digital no processo ensino-aprendizagem Fonte: Questionários aplicados aos alunos

Os dados acima referem-se aos jogos digitais como instrumentos metodológicos para a aquisição do conhecimento. De acordo com os resultados, $78 \%$ dos entrevistados responderam que eles podem ser utilizados como recurso didático, enquanto que, para $11 \%$ deles, talvez eles possam ser utilizados; $11 \%$ não responderam a questão. $\mathrm{Na}$ percepção dos alunos, o jogo pode ser direcionado como uma ferramenta metodológica para a construção do conhecimento, deixando de ser um mero suporte tecnológico e criando suas próprias lógicas e suas linguagens, com uma maneira particular de estimular as capacidades cognitivas dos alunos (KENSKI, 2004). Como se percebe, o jogo tem as suas potencialidades e são uma ferramenta que conquista e atrai o aluno, podendo ser adotado e trabalhado como uma metodologia inovadora para o processo de ensino-aprendizagem. 


\section{A prática do jogo adivinhas tabela periódica}

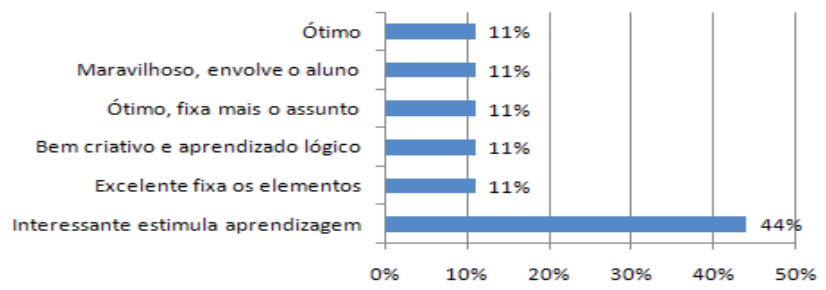

Gráfico 2- A prática do jogo de adivinhas tabela periódica Fonte: Questionários aplicados aos alunos

O gráfico acima demonstra que $44 \%$ dos alunos (B, D, E, I) acham a prática dos jogos digitais interessante e estimulante para a aprendizagem; para $11 \%$ dos alunos (A), os jogos são excelentes e ajudam a memorizar os elementos químicos. O aluno $\mathbf{C}(11 \%)$ afirma que o jogo é bem criativo e desenvolve o aprendizado lógico, mas o aluno $\mathbf{H}$ (11\%) coloca como excelente para fixação do assunto; outro aluno $\mathbf{F}$ (11\%) afirma ser o jogo um instrumento maravilhoso e envolvente; G (11\%) classifica o jogo como sendo ótimo. Dentre as variáveis apresentadas em relação à prática do jogo digital, os resultados revelaram-se significativos para o campo de aprendizagem, visto que trabalha a criatividade, aguça a memória, estimula e interage, gerando benefício para o conhecimento. Johnson (2001) afirma que nossa memória visual é muito mais duradoura que a memória textual. No entanto, os jogos digitais vão "além do conteúdo explícito da experiência" e aguçam o raciocínio lógico, dando um sentido visual, que facilita a percepção e contribui para o desenvolvimento da coordenação motora e da memória, de forma divertida.

Os recursos digitais presentes no cotidiano dos jovens estudantes permitem que a escola adicione como ferramenta didática os jogos digitais, nesse caso, proporcionando ao ensino da química, 
via intervenção tecnológica, uma oportunidade de diversão e de aprendizagem, através de um ambiente atrativo, que explora os diversos campos do saber científico.

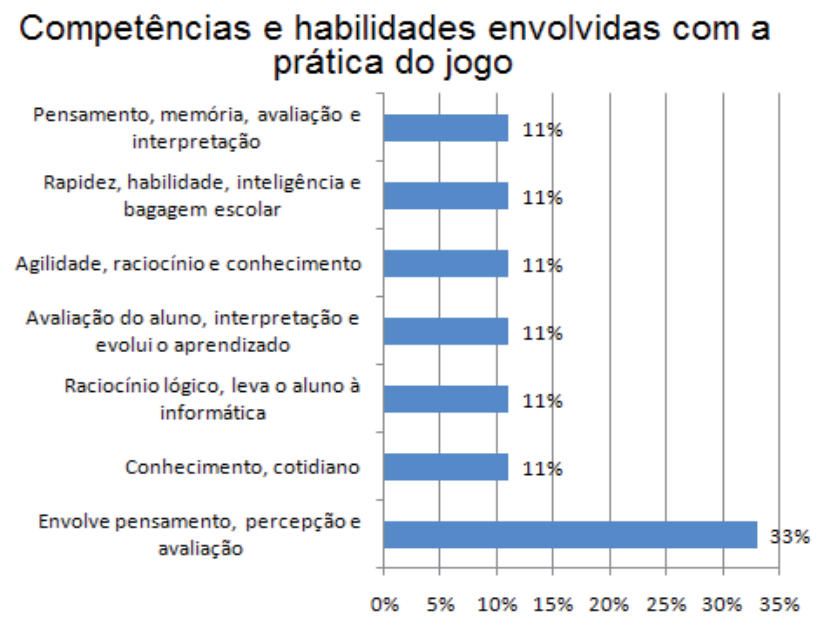

Gráfico 3 - Sobre as competências e as habilidades (envolve pensamento, percepção, avaliação etc) que o jogo desenvolve

Fonte: Questionários aplicados aos alunos

Os dados do gráfico apresentam as competências e as habilidades desenvolvidas com a prática do jogo, com os seguintes resultados: para $33 \%$ dos alunos (F, G e $\mathbf{H})$, os jogos digitais desenvolvem a percepção; aluno $\mathbf{A}(11 \%)$ revela que o jogo auxilia na aquisição de conhecimentos, através de exemplos cotidianos; o aluno B (11\%) afirma que o jogo desenvolve o raciocínio lógico e de informática; o aluno C (11\%) expressa que o jogo o ajudou a melhorar sua interpretação e evoluir no aprendizado; D (11\%) respondeu que a experiência resultou em uma maior agilidade, raciocínio e aquisição de conhecimentos; para o aluno E (11\%), o jogo lhe proporcionou rapidez, habilidade, inteligência e bagagem escolar; outros $11 \%$, 
representados pelo aluno I, afirmaram que o jogo estimulou o pensamento, a memória, a avaliação e a interpretação.

As respostas apresentadas evidenciam a busca pelo desejo de seguir e descobrir o que está por vir, o desejo de conhecer e de sondar (JOHNSON, 2005). Sondar e investigar o ambiente virtual para encontrar seus objetivos é uma maneira de vencer o jogo e melhorar sua desenvoltura no aprendizado da química.

Outro atributo do jogo é a investigação telescópica, representada pela necessidade de lidar, concomitantemente, com vários objetos. Com a prática desse jogo, todas as características citadas por Johnson e as competências e as habilidades almejadas são desenvolvidas com a evolução da aprendizagem, tais como: o raciocínio rápido, a memorização, o pensamento, a avaliação.

Assim, os jogos digitais devem ser direcionados à prática educativa, porquanto a escola é "um local de construção do conhecimento e de socialização do saber, um ambiente de discussão, de troca de experiências e de elaboração de uma nova sociedade, por isso, é fundamental que a utilização dos recursos tecnológicos seja amplamente discutida e elaborada" (BRASIL, 2001, p. 140), e para que se consiga um ambiente de aprendizagem divertido e interativo, via utilização dos recursos tecnológicos, o fazer educativo deve possibilitar o desenvolvimento de competências e habilidades, associadas à realidade de cada aluno, tendo em vista sua inserção social. 


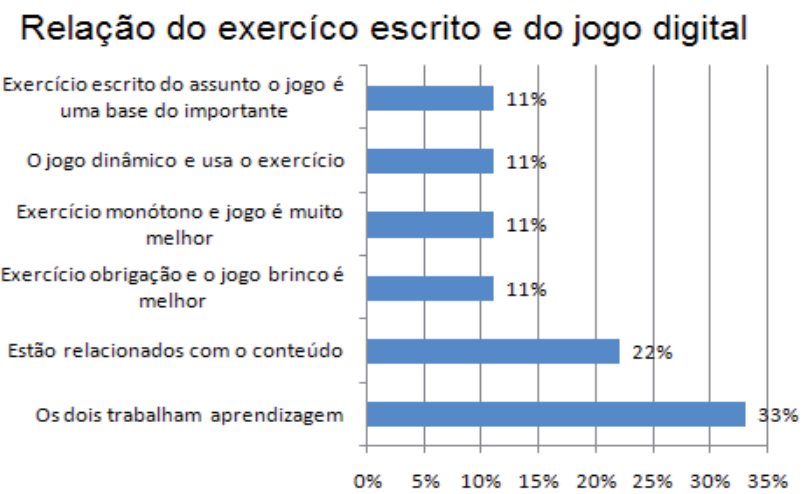

Gráfico 4 -Relação entre o exercício escrito e o jogo no processo de ensino e aprendizagem Fonte: Questionários aplicados aos alunos

Analisando as falas no gráfico acima, os dados revelam que $33 \%$ dos alunos (A, B e I) afirmam que tanto o exercício escrito quanto o jogo geraram aprendizagem; 22\% (E e D) acham que ambos estão relacionados com o conteúdo; para o aluno G (11\%), o exercício é uma obrigação, enquanto o jogo promove diversão e é bem melhor de aprender; o aluno $\mathbf{F}$ (11\%) afirma que o exercício é monótono, e o jogo, muito melhor; $\mathbf{H}(11 \%)$ concebe o jogo como dinâmico, mas o exercício, não; o aluno C (11\%) expressa que, assim como o exercício escrito sobre o assunto, o jogo também é importante para a aprendizagem.

A partir das várias respostas apresentadas, podemos detectar que os alunos $\mathbf{A}, \mathbf{B}, \mathbf{I}, \mathbf{E}$ e $\mathbf{D}$ têm a mesma linha de raciocínio, pois entendem que as duas ferramentas estão ligadas ao conhecimento e geram aprendizagem; o aluno $\mathbf{G}$ descreve que o exercício é como uma obrigação, ou seja não é atrativo, e não representa uma fonte de conhecimento, enquanto o jogo é motivador e desperta para o conhecer. O aluno $\mathbf{F}$ entra em sintonia com o $\mathbf{G}$, que considerou o exercício monótono, e o jogo, como melhor. Essas afirmações 
apresentam como diagnóstico a necessidade de práticas metodológicas que dinamizem as aulas, para que o aluno se sinta motivado a conhecer e interagir de forma atrativa, com praticas pedagógicas que utilize as potencialidades da tecnologia para a construção do conhecimento e a democratização do aprender no dinamismo da democracia.

O aluno $\mathbf{H}$ descreve que o jogo é dinâmico e que o exercício completa a aprendizagem; para $\mathbf{C}$, o jogo é o resumo do exercício escrito.

Tendo em vista esses aspectos, consideramos que o jogo pode ser um elemento frutífero para a aprendizagem mediante a utilização dos conteúdos escolares, prometendo ser útil e importante no processo de ensino e aprendizagem, com o intuito de criar ambientes que desenvolvam "maiores demandas cognitivas, mais profundidade, mais participação" que propiciaram os ganhos das últimas gerações em algumas formas de inteligência (JOHNSON, 2005).

\section{Relação da aprendizagem entre o exercício escrito e o jogo digital}

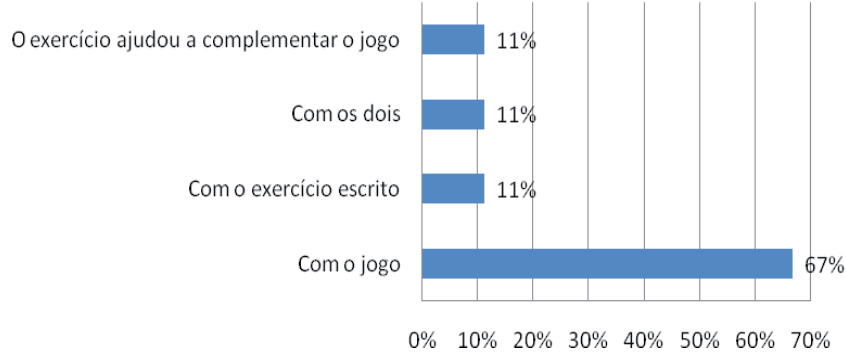

Gráfico 5 -Relação da aprendizagem entre o exercício escrito e o jogo digital advinhas.

Fonte: Questionários aplicados aos alunos 
O gráfico acima demonstra que $67 \%$ da amostra, o que corresponde aos alunos $\mathbf{A}, \mathbf{E}, \mathbf{F}, \mathbf{G}, \mathbf{H}$ e $\mathbf{I}$, afirmam que o jogo gera mais aprendizagem que o exercício, e $11 \%$, que correspondem ao aluno B, que o exercício escrito contribui para uma melhor aprendizagem; o aluno $\mathbf{C}(11 \%)$ considera que os dois instrumentos avaliativos desenvolvem a aprendizagem, e D (11\% da amostra) afirma que um instrumento completa o outro.

Os dados apresentados pelos alunos A, E, F, G, H expressaram que o jogo digital gera mais aprendizagem que o exercício escrito, desfazendo, assim, os tabus acerca desse recurso, tornando-o um meio de aquisição de conhecimento, quando associado a contextos que lhes deem sentido, no caso, o conteúdo da tabela periódica. $\mathrm{O}$ aluno $\mathbf{C}$ acha que os dois instrumentos promovem a aprendizagem, e o D descreveu que o exercício o ajudou a participar do jogo. No entanto, foi possível perceber que as duas ferramentas utilizadas se completam, sendo benéficas para a aprendizagem. Apenas o aluno B colocou que a aprendizagem é melhor no exercício escrito. Como percebemos, para uma significativa parcela da amostra, o jogo é benéfico para a aquisição de conhecimentos e gera aprendizagem.

Essa perspectiva deve ser norteadora do fazer educacional, uma vez que a utilização de tais recursos traz a ludicidade para o campo da aprendizagem, configurando-se como prazeroso para os alunos, através da participação interativa, fazendo a transposição didática entre o conteúdo e as tecnologias. Assim, os jovens aprendem com o que lhes é diretamente ensinado e desenvolvem padrões de participantes nas práticas desenvolvidas em cada comunidade, nesse caso, as comunidades dos games, o que inclui as práticas discursivas, o saber fazer e a utilização e a utilização dos diferentes recursos. Os conhecimentos encontram-se, por isso, associados aos contextos que lhes dão sentido (MOITA, 2006). 


\section{Considerações finais}

Este estudo relaciona o uso dos jogos digitais à pratica pedagógica, viabilizando o uso dos recursos tecnológicos ao ensino da ciência química, considerando os conceitos e as referências da área. A utilização dos jogos digitais, como ferramenta tecnológica, tem como seu principal público os jovens estudantes que buscam diversão e novidades nos ambientes tecnológicos. O jogo advinhas exige raciocínio rápido e lógico, no qual o aluno adivinha as respostas acompanhadas por um cronômetro, e cujo objetivo é avaliar o conhecimento do aluno acerca da tabela periódica de forma divertida e atrativa. Partindo desse apêndice, este trabalho teve como objetivo investigar a importância do jogo digital adivinhas tabela periódica para o ensino de química.

Através dos dados empíricos, ficou constatado que os jogos estão na vivência dos jovens e que os recursos tecnológicos utilizados como recursos didáticos facilitam o entendimento do assunto/conteúdo, gerando uma melhor aprendizagem. Outro ponto diagnosticado foi que uma significativa parcela que compôs a amostra, correspondente a um total de $78 \%$, aprovou o jogo como uma ferramenta didática muito bem apreciada. Eles afirmaram que gostam desse tipo de jogo e o consideram estimulante para a aprendizagem.

Portanto, os alunos consideraram que os jogos digitais são criativos e estimulam a memorização do conteúdo. Com o desenvolvimento do jogo adivinhas, foi possível identificar como a ludicidade estimula o raciocínio lógico, a aquisição de conhecimento, a agilidade, a memória e a evolução da aprendizagem. No que diz respeito à ligação do jogo com o exercício escrito, percebemos que os dois geram aprendizagem, mas alguns alunos argumentaram que o exercício se tornou uma obrigação, que era monótono, enquanto o jogo era divertido. 
$\mathrm{Na}$ análise comparativa, podemos depreender que $67 \%$ concebem que o jogo produz uma melhor aprendizagem, e $22 \%$, que os dois instrumentos (o questionário escrito e o jogo) facilitam a aprendizagem, pois ambos estão interligados.

Assim, a utilização do jogo digital, com fins didáticos, ficou diagnosticada como significativa para o processo de ensino e aprendizagem, no entanto, o uso desse recurso deve ser cuidadosamente planejado, para não se desviar do objetivo central. É preciso também salientar que os jogos digitais são apenas instrumentos, não mestres, ou seja, eles serão melhor utilizados se acompanhados por alguém que analise o jogo e o jogador, de modo diligente e crítico, sendo, pois, um complemento de apresentações formais, de leituras, discussões e conhecimentos.

A inserção dos jogos digitais na educação contribui para a formação de atitudes sociais baseadas no respeito mútuo, na cooperação, na obediência às regras, no senso de responsabilidade e na iniciativa pessoal e grupal. O enraizamento dessas atitudes na escola se torna possível com a disponibilização de técnicas pedagógicas lúdicas, que norteiem a participação dos alunos no âmbito da não-linearidade, em ambientes gratificantes e atraentes, o que, consequentemente, promoverá a autoaprendizagem, concomitante com uma mudança qualitativa no processo de ensino e aprendizagem.

Nessa perspectiva, este estudo revela a contribuição e o potencial que o jogo digital pode oferecer para o processo de ensino e aprendizagem, considerando que os dados coletados foram analisados segundo os conceitos da tabela periódica. Então, se escola estabelecer parceria didático-metodológica com esse recurso, estará ensinando de forma atrativa, inovadora e lúdica um conhecimento útil, concreto e presente na vida real dos alunos, colaborando para que sejam cidadãos ativos, capazes de construir e transformar suas histórias, enquanto sujeitos desse processo. 


\section{Referências}

ADIVINHAS SOBRE A TABELA PERIÓDICA. Disponível em: <http:// nautilus.fis.uc.pt/cec/jogostp/jogos/adivinhas/index.html>. Acesso em: 05 de março de 2008.

ALVES, L. R. G. Game over: jogos eletrônicos e violência. São Paulo: Futura, 2005.

ALVES, L. R.; NOVA, C. C. da; A comunicação digital e as novas perspectivas para a educação. In: ENCONTRO DA REDECOM, 1., 2002, Salvador. Anais... Salvador: REDECOM, 2002. Disponível em: < http://www.lynn. pro.br/pdf/art_redecom.pdf >. Acesso em: 17 de julho de 2008.

BRASIL. Ministério da Educação. Ciências da Natureza, Matemática e suas tecnologias. Brasília: Secretaria de Educação Médio e Tecnológica, 1999.

BRASIL. Ministério da Educação. Parâmetros Curriculares Nacionais: terceiro e quarto ciclos do ensino fundamental: introdução aos parâmetros curriculares nacionais.Brasília: MEC/SEF,2001.

JOHNSON, S. Surpreendente!: a televisão e o videogame nos tornam mais inteligentes. Rio de Janeiro: Elsevier, 2005.

JOHNSON, S. Cultura da interface: como o computador transforma nossa maneira de criar e comunicar. Rio de Janeiro: Jorge Zahar, 2001.

KENSKI, V. M.. Tecnologias e ensino presencial e a distância. 2. ed. Campinas: Papirus,2004. (Série Pratica Pedagógica).

KISHIMOTO, Tizuko Morchida (Org). Jogo, brinquedo, brincadeira e a educação. São Paulo: Cortez, 1999.

KISHIMOTO, T. M. O jogo e a educação infantil. São Paulo: Pioneira, 1994. 
LEVY, P. Cibercultura. 2. ed. São Paulo: Cotez, 2005

MOITA, F. M. G. S. C.. Games: contexto curricular juvenil. 2006. $181 \mathrm{f}$. Tese (Doutorado em Educação) - Universidade Federal da Paraíba, João Pessoa, 2006.

MOITA, F.. Game on: jogos eletrônicos na escola e na vida da geração @. Campinas: Alínea, 2007.

PERRENOUD, Philippe. Dez novas competências para ensinar. Porto Alegre: Artes Médicas Sul, 2000. 


\title{
Moodle no curso de ciências biológicas a distância: análise das contribuições no processo de ensino e aprendizagem
}

\author{
Ana Lígia Passos de Oliveira Costa \\ UEPB - Campina Grande, Paraíba \\ analigiajg@yahoo.com.br
}

Filomena $\mathrm{M}^{\mathrm{a}}$ Gonçalves da Silva Cordeiro Moita

UEPB - Campina Grande, Paraíba

filomena_moita@hotmail.com

A educação a distância é uma das modalidades de ensino e aprendizagem possibilitada pela mediação dos suportes tecnológicos digitais e de rede, seja inserida em sistemas de ensino presenciais mistos ou completamente realizada por meio da distância física.

Hoje, a EAD vive um período de mudanças, com o desenvolvimento de tecnologias que facilitam cada vez mais a aprendizagem em ambientes virtuais, de forma síncrona ou assíncrona. Com esse avanço, é possível observar o crescimento significativo da EAD, promovendo um novo espaço de aprendizagem fora das salas de aula. Começamos a passar dos modelos predominantemente individuais para os grupais. Das mídias unidirecionais, como o jornal, a televisão e o rádio, caminhamos para mídias interativas; da comunicação off-line, evoluímos para um mix de comunicação off e on-line 
(MORAN, 2006). Mas, de uma maneira ou de outra, para que o processo aconteça de forma desejada, é preciso que seja realizado dentro de uma proposta que possibilite maior interação e/ou interatividade entre o aluno e o professor-tutor.

$\mathrm{O}$ avanço das tecnologias interativas possibilitou o contato, em tempo real, entre várias regiões. Começaram, então, a surgir os diferentes tipos de softwares, capazes de desenvolver várias atividades dentro dos Ambientes Virtuais de Aprendizagem (AVA). Entre eles, o Moodle, um software livre, com um espaço destinado ao desenvolvimento de atividades on-line, utilizando-se diferentes tipos de ferramentas tecnológicas. É um ambiente de aprendizagem a distância, que foi desenvolvido pelo australiano Martin Dougiamas em 1999 (ALVES, 2005).

Vários Cursos do Ensino Superior vêm utilizando a plataforma do Moodle, como por exemplo, alguns Cursos de Biologia, revelando a possibilidade de contato com diferentes tipos de ferramentas tecnológicas (chats, fórum, e-mail interno, webquest), com as quais os estudantes podem desenvolver o processo de aprendizagem, através do acesso a um quadro bastante extenso de professores e tutores, numa dimensão impossível para uma única instituição educacional local. Porém, para que ocorra o processo de aprendizagem, é preciso haver uma mediação entre a metodologia aplicada e a necessidade do aluno, visando suprir as falhas que existem no desenvolvimento da autoaprendizagem, diagnosticando as ferramentas tecnológicas utilizadas que permitam uma melhor aceitação frente aos objetivos propostos pelo curso e à realidade do alunado. Nessa perspectiva, este texto analisa como as ferramentas tecnológicas do ambiente Moodle, utilizadas no Curso de Licenciatura em Ciências Biológicas, na modalidade a distância, da Universidade Estadual de Pernambuco (Polo de Campina Grande / UEPB), vêm facilitando o processo de aprendizagem. 


\section{Educação a distância}

A educação a distância vem crescendo rapidamente nos últimos anos, principalmente com o surgimento das novas tecnologias computacionais. Revendo esse histórico, é possível observar que, a partir do Século XX, foram realizadas várias experiências, em busca de novas metodologias de ensino, mediante a utilização do rádio e, posteriormente, com a televisão, até o emprego de artefatos computacionais. Assim, desde o uso dos correios, enquanto meio de comunicação (usando-se as mídias do tipo cartas), fitas-cassete, ou todo tipo de mídia que pudesse ser enviada, e com o advento da internet e de todas as ferramentas que esse meio disponibiliza (fórum, chat, hipertexto, e-mail, sites etc.), a educação a distância evoluiu, diminuindo o intervalo entre a emissão e a recepção da mensagem.

Segundo Peters (2003, p. 29), "este desenvolvimento ficou dramático nos últimos 25 anos, com o advento das universidades abertas, e está no momento ocorrendo com uma velocidade de tirar o fôlego com a criação das universidades virtuais". Com o crescimento da nova modalidade de ensino, trazendo as Universidades Abertas e Virtuais, várias pessoas terão oportunidade de estudar, devido à flexibilidade de tempo que a EAD oferece.

A educação aberta e a distância aparece cada vez mais, no contexto das sociedades contemporâneas, como uma modalidade de educação extremamente adequada e desejável para atender às novas demandas educacionais decorrentes das mudanças na nova ordem econômica mundial (BELLONI, 2003, p. 3).

Nos últimos anos, o ensino a distância tem se mostrado como uma das mais importantes ferramentas de difusão do conhecimento e de democratização da informação, colaborando, de maneira eficaz, com a preparação de profissionais para o mercado mundial. 
A educação a distância tem características específicas, que levam o aprendiz a desenvolver seus próprios conceitos. O traço distintivo dessa modalidade de ensino consiste na mediatização das relações entre os docentes e os discentes. Isso significa, de modo essencial, substituir a proposta de assistência regular à aula por uma nova proposta, na qual os docentes ensinam, e os alunos aprendem, mediante situações não-convencionais, ou seja, em espaços e tempos que não compartilham (LITWIN, 2001), favorecendo flexibilidade de tempo e promovendo a oportunidade de estudo para muitos que não podem estudar em um ambiente presencial.

\section{Influência das Novas Tecnologias em EAD}

As tecnologias avançam cada vez mais no cotidiano e impulsionam o homem a assumir uma postura que o coloque em atuação frente a essa nova realidade. Hoje é difícil imaginar a realização de determinadas atividades sem a utilização dessas tecnologias, pois o acesso a elas está cada vez mais fácil.

Nas atividades cotidianas, lidamos com vários tipos de tecnologias. Às maneiras, aos jeitos ou às habilidades especiais de lidar com cada tipo de tecnologia, para executar ou fazer algo, nós chamamos de técnicas. Algumas dessas técnicas são muito simples e de fácil aprendizado. São transmitidas de geração em geração e se incorporam aos costumes e hábitos sociais de um determinado grupo de pessoas (KENSKI, 2004 p.18).

A utilização das novas tecnologias afeta todos os campos educacionais, onde a educação a distância se destaca, através das várias metodologias empregadas nos cursos, com a finalidade de promover a formação do processo de aprendizagem e de autoaprendizagem dos alunos. As tecnologias diminuem a distância entre o aluno, o 
professor e o tutor, facilitando o processo de interatividade, que é fundamental para a formação do desenvolvimento de uma aprendizagem colaborativa.

No contexto educacional, as técnicas precisam ser escolhidas de acordo com o que se pretende que os alunos aprendam. Como o processo de aprendizagem abrange o desenvolvimento intelectual, afetivo, o desenvolvimento de competências e de atitudes, pode-se deduzir que a tecnologia a ser usada deverá ser variada e adequada a esses objetivos. Não podemos ter esperança de que uma ou duas técnicas, repetidas à exaustão, dêem conta de incentivar e caminhar toda a aprendizagem esperada (MASETTO, 2000, p. 133).

Quando empregadas como facilitadoras do processo de ensinoaprendizagem, as novas tecnologias de informação e comunicação indicam à sociedade, que enfrenta uma profunda transformação, um novo caminho, através de várias oportunidades e formas de comunicação, como ocorre na EAD, cuja característica fundamental é a utilização de tecnologias para mediar o contato aluno-professor, aluno-instituição, aluno-conteúdo e, na maioria das vezes, aluno-aluno. As Novas Tecnologias de Informação e Comunicação (NTICs) foram sendo apropriadas pela EAD e adequadas à realidade de cada curso (PAZ et al, 2003). No campo da educação, elas têm impacto significativo no que diz respeito ao acesso e exigirão adequações nas estratégias pedagógicas e de comunicação utilizadas por professores e alunos. A Web, por exemplo, juntamente com os programas de aprendizagem mediados por computador, é uma das formas didáticas que oferecem uma variedade de experiências de aprendizagem ao aluno, proporcionando-lhes maior flexibilidade, através de diferentes estilos de aprendizagem ao criar ambientes de aprendizagem acessíveis (VASCONCELOS, 2005). 
O advento da internet, nos cursos de Educação a distância, fez surgir a possibilidade de uso de diversos tipos de materiais similares aos já existentes, porém, com outros recursos, como por exemplo, as vídeoconferências, produzidas para serem transmitidas via web - como palestras ou simulações de uma situação ou experiências. Entretanto, o aluno pode não somente assistir à aula como também interagir, na mesma hora, através da internet, com webcan, telefone, e-mail, com o palestrante ou tutor. É possível, ainda, ver e ouvir outros alunos e discutir entre eles suas opiniões e idéias, mesmo estando em locais totalmente diferentes e distantes, realizando, portanto, uma interação de muitos para muitos.

O chat, o fórum, e o e-mail interno também são metodologias aplicadas através da Internet, por meio das quais os alunos, os professores e os tutores expressam suas opiniões, trocam idéias e dirimem dúvidas, mesmo estando em locais totalmente diferentes e distantes, exercitando uma interação de um para um, de um para muitos, de muitos para um e de muitos para muitos. Esse processo de interação contribui sobremaneira para o crescimento de sua aprendizagem.

O Webquest é uma metodologia de pesquisa na internet, por meio do qual são desenvolvidas atividades voltadas para o processo educacional. Trata-se de uma nova forma de ensinar e de prender usando-se a criatividade, de acordo com o objetivo que cada curso que o utiliza deseja atingir.

\section{Os tipos de aprendizagem em EAD e o controle/disciplina no tempo de estudo}

A aprendizagem decorre do processo de construção de conhecimentos que a sociedade produz historicamente. Nesse processo, a busca de informações e a leitura se destacam. Em qualquer ambiente, essa busca é um processo ativo, que conduz às transformações na humanidade. 
Na prática pedagógica, para que ocorra o processo de aprendizagem, é preciso que haja uma mediação entre a metodologia aplicada e a necessidade do aluno, visando suprir as falhas que existem no desenvolvimento da autoaprendizagem, e fazer uma avaliação contínua de toda a estrutura pedagógica do curso, para sanar as deficiências existentes e garantir o processo de aprendizagem e da autoaprendizagem do alunado.

O processo de ensino e aprendizagem, nos dias atuais, exige menos conteúdos e tempos fixos e mais processos de pesquisa e comunicação, porém um cuidado a ser tomado é com a extensão das oportunidades de informação e comunicação e as diversas fontes de acesso, sem perder de vista os objetivos estabelecidos e o aprofundamento na compreensão de conceitos, para não correr riscos de ficar apenas na superficialidade (SANTOS; CRUZ; PAZZETO; 2001, p. 5).

O método de estudo utilizado na EAD permite diferentes abordagens metodológicas e diversos enfoques, suscitando no aprendiz um desenvolvimento criativo, flexível à sua realidade, facilitando o seu crescimento pessoal, independentemente de sua região e/ou classe social. Essa modalidade de ensino possibilita a autoaprendizagem, através da mediação de recursos didáticos sistematicamente organizados, apresentados por meio de diferentes suportes de informação, podendo ser utilizados isoladamente ou combinados e veiculados pelos diversos meios de comunicação.

A principal característica da EAD é a flexibilidade de espaço e de tempo, que podem se adaptar às diversas demandas. Destarte, é considerada uma metodologia voltada para atender a adultos, com compromissos familiares e profissionais, pois permite que o indivíduo continue os estudos sem abandonar as outras atividades (DALMAU, et al., 2002). Sendo assim, é possível observar 
que os programas de educação a distância caracterizam-se pela flexibilidade que propõe em relação à organização do estudo e à administração do tempo.

Para se manter o processo de aquisição de conhecimentos, é fundamental a dedicação ao tempo de estudo estipulado na modalidade da EAD. Considerando a importância de se manter disciplina no cumprimento do horário de estudo, principalmente por causa da flexibilidade que a $\mathrm{EaD}$ permite, o aluno que não conseguir organizar seu tempo sofre consequências, entre elas, a deficiência de seu autoaprendizado, promovido pelo acúmulo de atividades atrasadas. A variável tempo, historicamente, foi considerada flexível e adaptável às possibilidades e às necessidades de cada aluno.

Em tempos recentes, muitos programas optaram por oferecer aos alunos uma proposta de ensino fragmentada em módulos de duração determinada (por exemplo, duas horas), de maneira que os estudantes concebam cada módulo de ensino como equivalente a uma aula do sistema presencial (SOLETIC, 2001, P. 80).

Portanto, cabe ao aluno se disciplinar e manter o seu horário de estudo rigorosamente dentro das atividades do dia-a-dia. Essa atitude, certamente, irá contribuir para aprofundar o seu processo de autoaprendizagem.

\section{Procedimentos metodológicos}

O estudo foi realizado no final do semestre de 2008.1, no Curso de Licenciatura em Ciências Biológicas a Distância da Universidade de Pernambuco, situado no Polo de Campina Grande, na Universidade Estadual da Paraíba. 
A pesquisa consiste em um estudo exploratório e descritivo, em que o procedimento adotado foi um levantamento de dados, utilizando-se como fonte de pesquisa o campo, com uma amostra de 43 alunos, de um universo de 72, selecionados através do critério de acessibilidade. Para obter os dados, aplicamos o instrumento questionário - constituído de oito questões de múltipla escolha (ver anexos), seguidas de espaço com indicação para o participante justificar as respostas e as questões abertas. Além da pesquisa, consultamos outras fontes de leitura, como artigos, livros e revistas acerca da temática em estudo.

Após a coleta dos dados, procedemos a tabulação com o apoio do programa do Microsoft Office Excel 2003 e foram elaborados gráficos que apresentamos a seguir. Por fim, foi feita a interpretação dos resultados, fundamentada nos pressupostos teóricos que nortearam a pesquisa.

\section{Coleta e análise dos resultados}

Com a finalização da aplicação do questionário, ficou constatado que, dos 43 (quarenta e três) alunos entrevistados, $60 \%$ são do sexo feminino, e $40 \%$, do sexo masculino, com faixa etária entre 20 a 50 anos, diagnosticando o quanto a educação na modalidade a distância abrange várias idades e proporciona aos aprendentes a chance de realizar um curso superior sem precisarem do tempo exigido no curso presencial.

A seguir, serão apresentados os dados obtidos e expostos em quadros, de acordo com cada questão do questionário (ver apêndice), com suas respectivas análises. 


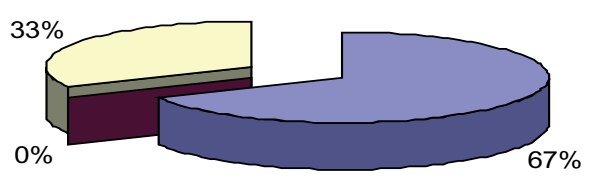

$\square \operatorname{Sim} \square$ Não $\square$ Em parte

Gráfico 1 - Processo metodológico e contribuições para a autoaprendizagem Fonte: Dados da pesquisa

Após a análise dos dados, verificamos que 29 (vinte e nove) alunos, do total de 43 (quarenta e três), o que corresponde a $67 \%$ da amostra, estão tendo um bom desenvolvimento no seu processo de autoaprendizagem. Isso se atribui ao processo metodológico que vem sendo desenvolvido na sua formação; 14 (quatorze) alunos (33\% do total) estão atingindo esse desenvolvimento em parte. Eles alegam a falta de clareza em relação à forma como os conteúdos de certas disciplinas se apresentam, que ainda estão adaptando ao ritmo da EAD e a dificuldade de organizar o seu horário de estudo e cumpri-lo.

O processo metodológico aplicado demonstrou resultados satisfatórios, porém é preciso observar os fatores que vêm causando deficiência no processo de aprendizagem dos alunos que se sentem prejudicados. Como colocam Pereira e Moita (2007), se a construção do conhecimento se efetiva de forma contínua e permanente, considerando o seu entorno, o processo de ensinar e aprender também vive esse mesmo processo, por isso é importante estar sempre atualizando e melhorando o Ambiente Virtual de Aprendizagem, com o objetivo de alcançar melhores resultados. 

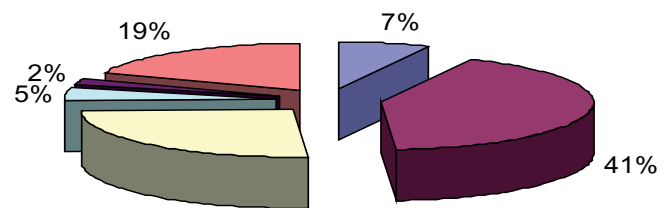

$26 \%$

$\square$ Fóruns Temáticos
$\square$ Webquest
$\square$ Leitura dos Fascículos
$\square$ Fóruns Temáticos e Webquest
$\square$ Fóruns Temáticos e Leitura dos Fascículos
$\square$ Webquest e Leitura dos Fascículos

Gráfico 2 - Ferramentas do Moodle que apresentaram maior rendimento Fonte: Dados da pesquisa

Observando o rendimento adquirido no processo de aprendizagem, o Webquest se destacou com a satisfação de 18 (dezoito) alunos, que corresponde a $42 \%$ do total. Os entrevistados alegam que a consulta ao Webquest, ou o próprio desenvolvimento das suas etapas, proporciona uma auto-aprendizagem gerada pelas várias atribuições que são sugeridas pelas atividades direcionadas, promovendo o desenvolvimento da capacidade dos alunos, através de pesquisas, apresentações, debates interativos, produção de material didático para o futuro docente, entre outros, estimulando-os a descobrirem suas habilidades. Como afirma Harasim et al (2005 p. 113), "o trabalho em rede assume a forma de uma ou mais tarefas importantes para o aprendizado num curso de educação a distância". 
A leitura dos fascículos se destacou em segundo lugar, com a aprovação de 11 (onze) alunos, perfazendo $25 \%$ o total da amostra. Esse percentual mostra a importância da leitura e do tempo que os alunos devem determinar para o seu estudo. Como menciona a literatura estudada, o aluno tem que determinar e cumprir o seu horário de estudo, pois a leitura é uma das atividades que requer mais tempo e concentração.

Com a continuação da análise dos dados, verificamos que oito alunos (19\% do total), responderam que sua aprendizagem tem mais rendimento com a utilização do Webquest e da leitura dos fascículos, simultaneamente, pois um proporciona a complementação e o auxílio do outro, dependendo da atividade a ser desenvolvida. Por outro lado, apenas três alunos (7\% da amostra) alegam maior rendimento nos fóruns temáticos. Para dois dos entrevistados (5\% do total), a aprendizagem passa a ser mais proveitosa utilizando o fórum temático e o Webquest ao mesmo tempo, e um aluno, (2\% do total) assegura que o fórum temático e a leitura dos fascículos trazem melhor resultado.

A análise dos dados revela uma diversidade de respostas que nos levam a refletir acerca da importância da utilização e da orientação em prol do uso correto das ferramentas tecnológicas, para que elas proporcionem resultados ideais, que corroborem com o objetivo do curso, considerando a particularidade de cada ferramenta do AVA, correlacionada com uma maior interação e interatividade do alunado para promover a aprendizagem desejada. 


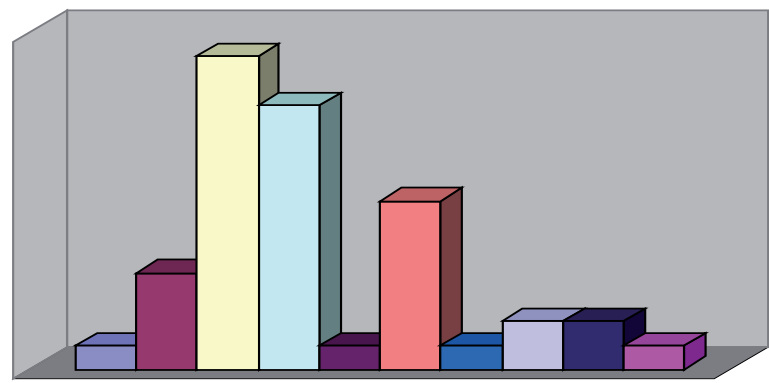

\begin{tabular}{l}
\hline Chat \\
$\square$ Fóruns Tira Dúvidas \\
$\square$ Need \\
$\square$ Webquest \\
$\square$ Chat e Fórun Tira Dúvidas \\
$\square$ Need e Webquest \\
$\square$ Chat e Need \\
$\square$ Fórum Tira Dúvidas e Webquest \\
$\square$ Chat, Need e Webquest \\
$\square$ Chat, Need, Webquest e Fórum Tira Dúvidas
\end{tabular}

Gráfico 3 - Ferramentas tecnológicas do ambiente Moodle que vêm sendo utilizadas de forma mais satisfatória para sanar as dúvidas dos alunos

Fonte: Dados da pesquisa

O Ambiente Virtual de Aprendizagem (AVA) Moodle também dispõe de ferramentas que podem ser utilizadas para dirimir as dúvidas dos alunos que surgem ao longo de seus estudos. Tais ferramentas, como revela a tabela acima, fizeram parte desta pesquisa e tiveram os seguintes resultados na sua funcionalidade: o Need (e-mail interno) auxiliou da melhor forma, segundo 13 alunos (30\% da amostra), os quais alegaram que o e-mail interno favorece uma maior interação e interatividade com os tutores e professores, esclarecendo as dúvidas de forma mais satisfatória.

Com base na literatura pesquisada e nos resultados apontados na tabela acima, observamos a importância da responsabilidade de se manter uma comunicação constante e clara entre os discentes e os docentes que fazem parte do elenco do curso, empregando-se as ferramentas que são disponibilizadas no ambiente Moodle. Isso 
significa que não basta dispor da tecnologia, é preciso empregá-la de forma correta e satisfatória.

A análise dos dados ainda nos revela que 11 (onze) entrevistados, representando um percentual de $26 \%$ da amostra, afirmaram que o Webquest trazia informações suficientes, que lhes esclareciam as dúvidas quando recorriam a ele. A integração de links bem elaborados nos software educativos facilita o processo de autoaprendizagem e estimula o alunado.

Os dados também expressam que sete alunos (17\% do total) utilizam o Need e o Webquest, simultaneamente, para sanar as suas dúvidas, averbando que a interação entre as duas ferramentas ocorre de forma completa. Já para quatro alunos ( $9 \%$ da amostra), o fórum tira dúvidas é mais aceito. Eles referem que esse instrumento é utilizado, mas sem a eficiência das ferramentas já comentadas.

Algumas ferramentas, como o Webquest e o fórum tira dúvidas, vêm destacadas com certa importância, para o desenvolvimento da aprendizagem e a solução das dúvidas dos alunos, e apresentam suas funções no processo de ensino-aprendizagem de forma significativa.

Esses dados condizem com o pensamento de Harasim et al (2005 p. 187), em cujas pesquisas destaca que, em muitos sentidos, os cursos on-line são como um jardim, no qual, seu projeto representa a forma como as plantas serão distribuídas e combinadas, a fim de produzir harmonia e contraste. Em um curso on-line, o projeto diz respeito às diferentes estruturas criadas para manter $\mathrm{e}$ dar forma à interação entre os participantes, bem como ao encadeamento das várias formas de interação. 


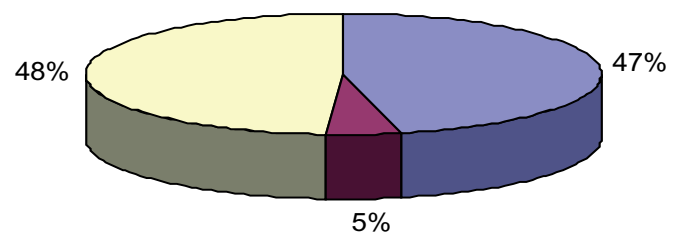

\footnotetext{
$\square \operatorname{Sim} \square$ Não $\square$ Em parte

Gráfico 4 - Clareza e funcionalidade do material didático (fascículo)

Fonte: Dados da pesquisa
}

De acordo com a amostra apresentada no gráfico acima, 21 (vinte e um) alunos, (49\% da amostra) afirmaram que sentem dificuldade em parte, em relação à falta de clareza dos fascículos (material didático) para a desenvolvimento do seu processo de aprendizagem. Vinte entrevistados, do total de 43 (quarenta e três), estão satisfeitos com o material. Já 2 dois alunos (4\% da amostra) alegaram insatisfação, por considerarem o material incompleto e sentirem dificuldade de utilizá-lo.

O material didático utilizado na EAD deve promover uma leitura clara, propor atividades que os alunos realizem mesmo estando sozinhos ou com um grupo de colegas, para favorecer a interatividade, fazendo com que ele sinta a necessidade de voltar a pesquisar no mesmo. O material didático precisa "conversar" com o aluno, precisa seduzi-lo. Portanto, é necessário realizar alternativas que sanem o problema, levando os alunos a explorarem o material virtual e se habituarem a pesquisar em outras fontes. 


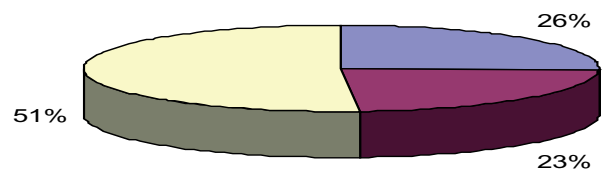

$\square \operatorname{Sim} \square$ Não $\square$ Em parte

Gráfico 5 - Participação dos alunos nos fóruns temáticos

Fonte: Dados da pesquisa

De acordo com a análise dos dados, 22 (vinte e dois) alunos num percentual de $51 \%$, revelaram que participam dos fóruns temáticos em parte, e 10 (dez) (23\% da amostra) afirmaram que não participam, alegando os seguintes motivos: falta de interesse pelo tema, deficiência na interação do professor e falta de tempo. Já 11(onze) entrevistados, representando $26 \%$ da amostra, demonstraram satisfação pela participação. Os dados coletados apontam para a possibilidade de que se as atividades tiverem uma continuidade, outros alunos podem melhorar a sua participação.

Os dados mostram que a participação nos fóruns temáticos não foi tão significativa, tendo em vista que apenas a minoria do total de alunos participou ativamente. Esse resultado demonstra como o processo de interatividade pode ter sido prejudicado nessa metodologia. Isso demonstra que é importante se pensar na necessidade de se potencializar o processo de interação dos fóruns temáticos, para que a construção do conhecimento seja feita de maneira mais colaborativa. 


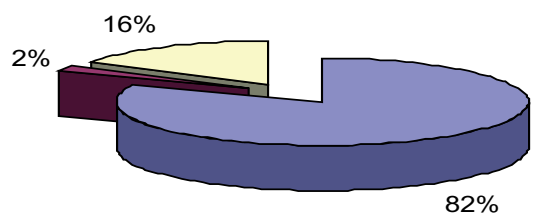

$\square \operatorname{Sim} \square$ Não $\square$ Em parte

Gráfico 6 - Aceitação do ambiente virtual de aprendizagem (AVA) Moodle Fonte: Dados da pesquisa

Diante da análise dos dados, verificamos que, do total de 43 (quarenta e três) alunos (representado 82\% da amostra), 35 (trinta e cinco) responderam que o Moodle atende as suas expectativas, ou seja, a maioria dos alunos utiliza o ambiente virtual de maneira satisfatória, enquanto que sete, perfazendo um total de $16 \%$ do total, alegaram que o utilizam em parte, e apenas um respondeu que não, o que corresponde a $2 \%$ da amostra. Estes dois últimos percentuais de alunos afirmaram que não tinham muita prática em informática e, por isso, não sentem facilidade em utilizar o ambiente virtual.

O Moodle é um software livre, fácil de utilizar e se enquadrou de forma significativa no processo de aprendizagem dos alunos do Curso de Licenciatura em Ciências Biológicas na modalidade a distância. A internet, juntamente com os programas de aprendizagem mediados por computador, agrega uma das formas didáticas que oferecem ao aluno uma variedade de experiências de aprendizagem, proporcionando maior flexibilidade a indivíduos com diferentes estilos de aprendizagem ao criar ambientes de aprendizagem acessíveis (VASCONCELOS, 2005). 


\section{Reflexões finais}

Tendo em vista os aspectos analisados neste estudo, chegamos às seguintes conclusões:

a) Apesar dos pontos ressaltados como positivos, não podemos deixar de destacar que, mesmo com uma boa aprovação do Ambiente Virtual de Aprendizagem (AVA), no processo de autoaprendizagem, ele tem muitos recursos que ainda não são utilizados e que necessitam de se adequar para o melhor desenvolvimento do alunado, pois, apesar da dificuldade que alguns alunos apresentam para utilizar a internet, o AVA Moodle vem estimulando-os a conquistar, cada vez mais, o conhecimento, através de suas ferramentas, promovendo um processo de interação e de interatividade significativo entre tutores e professores.

b) O Webquest é bem aceito pelos alunos como uma ferramenta que proporciona maior aprendizagem, devido, principalmente, às várias atividades que proporciona, levando os alunos a pesquisarem e a desenvolverem várias formas de adquirir conhecimento, dependendo do que ele pede e viabiliza ao alunado.

c) O Need (e-mail interno) é a ferramenta mais utilizada como meio de comunicação assíncrona para esclarecer dúvidas e atribuir informações necessárias ao alunado. Já o Chat, apesar de ser síncrono, não é uma participação tão efetiva por parte do corpo discente e docente do curso em relação ao Need.

d) O processo de adaptação em relação à flexibilidade do horário de estudo faz com que muitos alunos não tenham a organização de seu tempo e o compromisso necessário a ser cumprido rigorosamente, dentro do período determinado 
pela exigência das disciplinas, levando à falta de dedicação esperada e, consequentemente, ao desestímulo.

e) O material didático utilizado na EAD deve propor atividades que os alunos realizem mesmo estando sozinhos ou com um grupo de colegas, pois isso favorece a interatividade e a aprendizagem colaborativa e os estimula a continuarem suas pesquisas nesse instrumento de aprendizagem. É necessário desenvolver estratégias por meio das quais seja possível sanar dificuldades que o aluno possa apresentar ao utilizar o seu material didático, para que ele possa explorá-lo de forma virtual e adquirir o hábito de pesquisar em várias fontes.

f) A metodologia aplicada no curso é adequada e traz rendimento, porém se deve sempre investigar e corrigir eventuais falhas, que vão surgindo durante o processo de aperfeiçoamento do curso e priorizar as necessidades dos alunos em relação ao engrandecimento do seu processo de autoaprendizagem.

Apesar dos pontos ressaltados como positivos, não podemos deixar de destacar que, mesmo com uma boa aprovação do Ambiente Virtual de Aprendizagem (AVA) no processo de autoaprendizagem, ainda há muitos recursos que não são utilizados e que precisam ser adequados para o melhor desenvolvimento do alunado.

\section{Referências}

ALVES, L.; BRITO, M. 0 ambiente Moodle como apoio ao Ensino Presencial. Disponível em: <http://www.abed.org.br/congresso2005/ por/pdf/085tcc3.pdf >. Acesso em: 10 abr. 2008. 
BELLONI, M. L. Educação a Distância. 3.Ed.Campinas,Sp: Autores Associados, 2003.

DALMAU, M. B. L. et al. A Educação Profissional, a EAD e as

Universidades Corporativas: um mercado emergente. 2002.

Disponível em: <http://www.abed.org.br/publique/cgi/cgilua.exe/sys/ start.htm? UserActiveTemplate $=4$ abed\&infoid $=196 \&$ sid $=102>$. Acesso em: 6 de novembro 2006.

HARASIM, L. et al. Redes de aprendizagem: um guia para ensino e aprendizagem on-line. São Paulo: Senac São Paulo, 2005.

KENSKI, V. M.Tecnologias e ensino presencial e a distância. 2. ed. São Paulo: Papirus, 2004.

LITWIN, E. Das tradições as virtudes. In: LITWIN.E. Educação a distância. Porto Alegre: Artmed, 2001. p.13-22.

MASETTO, M. T. Mediação pedagógica e o uso da tecnologia. In:

MORAN, I. M. Novas tecnologias e mediação pedagógica. São Paulo: Papirus, 2000. p. 133-173.

MORAN, J. M.; MASETTO, M. T.; BEHRENS, M. A. Novas tecnologias e mediação pedagógica. 12. ed. São Paulo: Papirus, 2006.

PAZ, C. R. et al. Monitoria on-line em educação a distância: o caso LED/ UFSC. In: SILVA, M. Educação On-line. São Paulo: Loyola, 2003. p.327 -344 .

PEREIRA, M. Z. da C.; MOITA, F. M. G. da C. Educação, tecnologia e comunicação: os jogos eletrônicos e as implicações curriculares. In: SILVA, E. de M.; MOITA, F. M. G. da C.; SOUSA, R. P. Jogos Eletrônicos: Construindo novas trilhas. Campina Grande: Eduep, 2007. p. 83-103.

PETERS, O. Educação a distância em transição. São Leopoldo: Unisinos, 2003. 
SANTOS, E. F. G.; CRUZ, D. M.; PAZZETTO, V. T. Ambiente educacional rico em tecnologia: a busca do sentido. Disponível em: $<$ http:// www.abed.org.br/publique/cgi/cgilua.exe/sys/start.htm?UserActiveTem plate $=4$ abed\&infoid=187\&sid=102 . Acesso em: 6 de nov. de 2006 .

SOLETIC, A. A produção de materiais escritos nos programas de educação a distância: problemas e desafios. In: LITWIN, E. Educação à Distância. Porto Alegre: Artmed, 2001. p.73- 92.

VASCONCELOS, S. D. 0 papel da tecnologia da informação na educação biológica: comentários sobre a experiência italiana. Recife: UFPE, 2005. 1 CD-ROM. 



\title{
O sociointeracionismo no contexto da EAD: a experiência da UFRN
}

\author{
Maria Dalva de Oliveira Araujo \\ UEPB - Campina Grande, Paraíba \\ dalvaoa@hotmail.com \\ Ana Beatriz Gomes Carvalho \\ UEPB-Campina Grande, Paraíba \\ anabeatrizuepb@gmail.com
}

\section{Introduç̃̃o}

A educação escolarizada em seus diversos níveis e modalidades vem atender determinantes de ordem econômica e cultural em cada momento histórico da sociedade. No sistema capitalista brasileiro, com a globalização da economia e o avanço científico e tecnológico, ocorreu o avanço rápido da era agrícola que marcou o período colonial para a atual caracterizada como era do conhecimento. O surgimento crescente de novos recursos tecnológicos possibilita formas de comunicação e articulação de informações cada vez mais diversificadas, provocando mudanças significativas nos modos de vida em todas as suas dimensões. Isso aporta a necessidade de ampliação do conhecimento em si e do conhecimento em torno dos recursos tecnológicos disponíveis, bem como o conhecimento 
sobre o próprio homem e suas inter-relações pessoais e profissionais. Obviamente, as necessidades de aprendizagem do momento atual divergem das necessidades do período agrário, haja vista que afetam diretamente o pensar e o agir nas relações econômicas e sociais demandando um grau cada vez mais elevado de escolarização, especialmente para a população urbana.

Todavia, em se tratando de ensino superior público no Brasil, estudos mostram que há uma redução de participação social neste nível de ensino, nas últimas décadas. Isso veio impulsionar o desenvolvimento de políticas que potencializem o acesso de camadas da população com dificuldades de deslocamento e disponibilidade de tempo real para o estudo em cursos de graduação. A implementação da Educação a Distância surge, então, como uma alternativa viável de democratização do ensino superior.

Valente (2003), até por volta do ano de 1999, a EAD tinha sido utilizada como uma alternativa à educação presencial. Entretanto, a partir do advento das novas TIC e com a crescente demanda por mais educação, ela apresenta-se atualmente como uma solução no sentido de oportunizar o acesso a cursos de graduação por parte de diversas camadas da sociedade. Assim, a disseminação de cursos a distância nas universidades públicas, com apoio do governo federal, proporcionou a formação de uma verdadeira rede de pesquisa sobre os fundamentos e estratégias de aprendizagem na educação a distância.

Nessa perspectiva, o estudo dos fundamentos teóricos que alimentam as práticas pedagógicas nos cursos de licenciatura na modalidade a distância, parece constituir um problema relevante de ser estudado. Entendemos que a existência de um novo contexto histórico-social no qual o conhecimento passa a representar o principal modo de produção econômica, exige uma nova modalidade de ensino e de aprendizagem. Pressupõe que os elementos inovadores tenham sido incorporados de forma automática nas práticas pedagógicas. 
Entretanto, nem sempre isso acontece facilmente, e uma das dificuldades da EAD é justamente o descompasso entre as propostas político-pedagógicas incrementadas contemplando novas tecnologias e novas estratégias de ensino e aprendizagem e sua operacionalização de fato. Isso implica dizer que, embora contando com ferramentas tecnológicas no processo de ensino e aprendizagem a distância, o material didático proposto, as atividades e a avaliação do conteúdo, muitas vezes reproduzem modelos repetitivos e mecânicos predominantes no paradigma tradicional meramente instrucionista.

Nesse sentido, ressaltamos que uma prática pedagógica inovadora condizente com as exigências da sociedade contemporânea e, conseqüentemente, com as necessidades de aprendizagem dos alunos, envolve (re) significar o ensinar e o aprender promovendo uma mudança paradigmática no sentido de estabelecer uma relação horizontalizada entre seus atores.

Nessa modalidade de ensino, o principal meio para efetivação de uma proposta de curso é o material didático utilizado. Todavia, mesmo com a utilização de ferramentas das tecnologias interativas, ainda é o material didático impresso que sustenta predominantemente a mediação didática. A esse respeito, Bédard (2005, p.229), parafraseando Litto (2002), destaca: "posso afirmar que, apesar das constantes inovações tecnológicas, os cursos por correspondência irão continuar." O autor continua afirmando que quem se dispuser a estudar ou pesquisar a Comunicação Didática Escrita (CDE) e/ou Material Didático Impresso (MDI) contribuirá para esclarecer as condições de EAD eficaz e eficiente. Além do mais, a mídia impressa constitui uma forma de acesso mais democratizado, principalmente, para os alunos que não dispõem ou têm dificuldades de manusear os recursos tecnológicos necessários ao ensino virtual. Esses aspectos foram determinantes no sentido de realizarmos este trabalho que foi norteado pela questão: Que elementos subjacentes no projeto de cursos de licenciatura a distância 
refletem pressupostos da abordagem sociointeracionista de educação e como estes repercutem na prática pedagógica mediatizada, predominantemente, pelo material didático impresso?

\section{0 contexto da pesquisa}

A idéia desta pesquisa surgiu no decorrer do curso de Especialização em Novas Tecnologias na Educação, quando refletimos sobre Paradigmas Educacionais e, durante a disciplina Educação a Distância, realizamos uma atividade na qual avaliamos os materiais didáticos impressos utilizados em diferentes cursos, por várias universidades na cidade de Campina Grande/PB. A partir disso, elegemos como objetivo geral analisar a presença de pressupostos sociointeracionistas nos Cursos de Licenciatura em Matemática, Química e Física a Distância, oferecidos pela UFRN na cidade de Campina Grande, na Paraíba. Para realizar esta análise buscamos estabelecer a relação destes, com a prática pedagógica desenvolvida, através do material instrucional impresso utilizado na disciplina Educação e Realidade. A opção por esta disciplina foi baseada no fato de constituir disciplina comum aos três cursos, durante o primeiro semestre. Destacamos ainda que o próprio nome da disciplina, por sugerir um paradigma educacional centrado na ligação da prática pedagógica com o contexto social, influenciou de forma decisiva em nossa escolha.

O estudo consistiu numa pesquisa descritiva, qualitativa com foco na análise documental e se desenvolveu em três momentos distintos: 1) revisão bibliográfica em torno do problema em estudo; 2) leitura e a coleta de dados a partir dos documentos (projetos dos cursos de licenciatura a distância - UFRN, oferecidos na cidade de Campina Grande/PB - e fascículos da disciplina Educação e Realidade), ambos disponibilizados pela UFRN e 3) a análise das informações coletadas. 
Dando sustentação às reflexões, utilizamos autores cujas idéias refletem pressupostos da abordagem sociointeracionista de ensino e aprendizagem, a exemplo de L. S. Vygotsky e Paulo Freire, além de outros cujo pensamento representa contribuições significativas. Ressaltamos que, a nosso ver, a teoria defendida por estes autores constitui referencial de um paradigma inovador na educação como um todo e, particularmente, na EAD. Para alimentar a análise do material didático (mídia impressa), consideramos pesquisas e trabalhos desenvolvidos nesse campo por alguns autores. Dentre eles citamos: Maria Lúcia Cavalli Neder (2005), Lucia Helena Vendrusculo Possari (2005), Roger Bédard (2005), Aluízio Belisário(2003), Leda Maria Rangearo Fiorentini (2003), Angeles Soletic (2001), entre outros que, em linhas gerais também contribuíram para nosso estudo.

Os instrumentos utilizados para a análise dos dados foram a seleção e categorização dos elementos (através do fichamento) e a construção de tabelas. O fichamento é uma parte importante na organização para a efetivação da pesquisa de documentos. Ele permite um fácil acesso aos dados fundamentais para a conclusão do trabalho. A tabela permite a visualização dos dados de forma sucinta facilitando a análise e interpretação dos mesmos.

Os documentos utilizados para a pesquisa foram: os Projetos Político- Pedagógicos dos três cursos de Graduação (licenciatura), na área das Ciências - Matemática, Química e Física, na modalidade a distância, implantados pela Universidade Federal do Rio Grande do Norte (UFRN) e oferecidos na cidade de Campina Grande - Paraíba. Além disso, utilizamos os quinze fascículos que constituem o material instrucional impresso norteador dos estudos ao longo da disciplina Educação e Realidade, componente curricular comum aos cursos referenciados, no primeiro semestre letivo.

Para a realização desta pesquisa documental, encaminhamos um requerimento à Instituição, especificamente, à coordenação dos cursos, solicitando a colaboração no sentido de viabilizar o material 
necessário (apêndice a). Após a disponibilização dos documentos pudemos dar início à investigação iniciando pela revisão bibliográfica relacionada e efetivação do trabalho propriamente dito: estudo e análise dos projetos, estudo e análise dos fascículos da disciplina Educação e Realidade e o confronto dos dados coletados, buscando vislumbrar os elos existentes entre o Projeto Político-Pedagógico dos cursos e pressupostos sociointeracionistas de educação, bem como a repercussão na prática pedagógica por meio do material didático impresso.

\section{Os Elementos Sociointeracionistas na Proposta Político-Pedagógica dos Cursos de Licenciatura a Distância da UFRN}

A análise da proposta sociointeracionista nos cursos a distância da UFRN e sua efetiva realização constituiu a complexidade deste trabalho e está relacionada com a identificação dos elementos que a caracterizam no projeto político-pedagógico dos cursos (considerado como uma intenção) e no material impresso da disciplina Educação e Realidade, componente curricular dos cursos analisados (considerado neste trabalho como a realização da proposta). Para tanto, selecionamos os elementos que julgamos importantes na caracterização do sociointeracionismo, na perspectiva dos autores escolhidos para a fundamentação teórica.

Após a análise dos projetos elaboramos um esquema contemplando seus vários itens. Selecionamos os elementos comuns aos três cursos, que consideramos essenciais ao alcance dos objetivos propostos neste trabalho. A partir do item "projeto pedagógico", categorizamos seis elementos que nos pareceu refletir pressupostos sociointeracionistas e que deram suporte às nossas reflexões. Foram os seguintes: 1) Proposta de Ensino, 2) Concepção de Aprendizagem, 3) Concepção de Aluno, 4) Concepção de Professor, 5) Conteúdo e 6) Abordagem. 
A proposta de ensino explicitada nos três projetos está centrada na ação pedagógica voltada para o aluno, ao invés da turma. Esta proposição vem mostrar a superação da prática educativa tradicional na qual se estabelece um arsenal de conteúdo de cima para baixo a ser deglutido pelos estudantes de forma igualitária, no mesmo período de tempo, de modo a atingir um nível pré-estabelecido para todos. Dessa forma, se desconsidera totalmente as particularidades em termos de aspectos intra e intersubjetivo que permeiam o processo de aprendizagem. Esse deslocamento de foco parece atender ao pressuposto sociointeracionista de que cada indivíduo é singular no seu processo de desenvolvimento, embora este ocorra por intermédio do convívio social. Considera, portanto, que ao ser submetido ao processo educativo, este indivíduo já possui um repertório de experiências de vida que precisam ser consideradas na elaboração do currículo institucional. Trata-se de um currículo oculto que precisa ser desvelado a fim de constituir ponto de partida para a ação pedagógica significativa.

$\mathrm{Na}$ perspectiva sociointeracionista o processo de ensino é expandido de modo a incorporar as relações socioculturais, podendo garantir um arsenal teórico que favoreça pensar um modelo educacional mais coerente com as exigências da sociedade, não apenas em termos de realização profissional, mas também em termos de realização pessoal. Desse modo, favorece a problematização das condições existenciais dos indivíduos, levantando situações-problema que possam ser trabalhadas no contexto pedagógico a fim de contribuir, de alguma forma, para a transformação do meio social, assim como favorecer a constituição do próprio sujeito. Nisso se concretiza a dinamicidade de um processo educativo "vivo" que age articulando a reflexão prática-teoria-prática, numa espiral, ora se aproximando, ora se distanciando da realidade concreta no sentido de melhor compreendê-la e melhor atuar sobre ela.

Para Valente (2003), o que marca a transformação no processo de ensino na sociedade contemporânea é, justamente, o deslocamento 
da ênfase neste, para colocá-la na aprendizagem, na construção do conhecimento e não na instrução. A nosso ver, caberia acrescentar a esse último termo a expressão - apenas. Isso porque entendemos que o fato de ampliarmos o olhar para o processo educativo de modo a contemplar a aprendizagem como o produto central da ação pedagógica, não dispensa definitivamente a instrução. Esta, de certa forma, continua e continuará existindo na ação educativa, sendo que de uma forma diferente, mais humanizante, libertadora, conscientizadora do papel social de cada indivíduo e não lidando com seres inteligíveis como se fossem "coisas", objeto de manipulação de outros.

A Concepção de Aprendizagem apresentada no item princípios norteadores da organização curricular, destaca como princípio fundamental a maneira como se concebe a aprendizagem: "ela é mais efetiva quando é significativa para o aluno, quando se alicerça nas relações e quando se constitui em uma construção coletiva que considera as diferenças de desenvolvimento e as diversidades sociais e culturais" (UNIVERSIDADE FEDERAL DO RIO GRANDE DO NORTE, 2004c, p. 14). Este item nos possibilita reforçar a idéia de projeto inovador mencionada anteriormente em referência ao ensino superior. Até porque tem sido verificado nesse nível de ensino ao longo do tempo, que pouca ou nenhuma preocupação existe quanto ao nível de desenvolvimento atual, ou real, tão propalado por Vygotsky (1988) como o ponto de partida para o processo educativo. É comum centrar-se o ensino em conteúdos pré-determinados, sem conhecimento do conhecimento prévio dos alunos e de quem são esses alunos para os quais os cursos se destinam. Dessa forma, impõem-se conteúdos desvinculados tanto da zona proximal de desenvolvimento do aluno na qual, segundo a teoria vygtskiana a ação educativa precisa atuar, quanto do contexto social em que os alunos vivem. Conseqüentemente, esse descaso da universidade com o tratamento da aprendizagem do aluno enquanto processo em contínua construção, muitas vezes, potencializa a exclusão social. 
Considerar a efetividade da aprendizagem significativa do aluno, evidentemente, é um propósito ousado que abrange uma gama de conhecimentos e procedimentos didáticos. Isso envolve a necessidade de clareza dos fundamentos epistemológicos do processo de aprendizagem e suas relações com as dimensões sociais e econômicas que delineiam os paradigmas educacionais em cada momento histórico da sociedade.

No processo educativo, situações de aprendizagem planejadas e efetivadas necessitam ser propícias ao aluno, conforme o suposto tratamento dispensado ao paciente no campo da medicina exemplificado acima. O aluno em si aponta para uma dupla direção do processo educativo. Por um lado constitui objeto de estudo em suas várias dimensões: cognitiva, afetiva, social, entre outras e, por outro, é sujeito desse processo, melhor dizendo, o estudante é ao mesmo tempo objeto e sujeito desse processo. Isso induz tratá-lo não como uma folha em branco na qual a instituição escolar irá imprimir a sua marca que deverá permanecer para sempre registrada na sua mente, mas como alguém que existe, tem vida, tem uma história de vida já construída, tem interesses, vontade, necessidades. A aprendizagem significativa reporta considerar tudo isso estabelecendo esse leque de relações e inter-relações. Ilustrando estas questões subjacentes ao processo de aprendizagem, D'avila (2006), com base em Jonassem (1996), destaca como características importantes para a efetivação da aprendizagem significativa do aluno: a ação, a construção, a reflexão, a cooperação, a intenção, a socialização.

A Concepção de Aluno é de sujeito do seu aprendizado, desenvolvendo autonomia e independência em relação ao professor. Esta concepção parece constituir um dos pressupostos apresentados por Vygotsky (1988), que ressalta a ação do sujeito no seu processo de aprendizagem. Para este autor, o aluno ao ingressar no contexto escolar traz consigo um conjunto de saberes já efetivados definido como o Nível de Desenvolvimento Real (NDR) que o capacita 
realizar sozinho, ou seja, de forma autônoma algumas tarefas, como por exemplo, narrar acontecimentos vividos. Isto provavelmente acontece desde a fase pré-escolar em que a criança já domina a linguagem oral adquirida nas interações com o seu grupo familiar e social. Ao mesmo tempo, traz uma margem de possibilidades que poderá ser efetivada com a cooperação ou colaboração de outros sujeitos mais experientes. Por exemplo, o aluno passa da produção meramente oral para a produção escrita de textos que é propiciada com a mediação do professor e de outros colegas. A este espaço ou margem de possibilidades Vygotsky (1988) denominou Zona de Desenvolvimento Proximal (ZDP). Segundo ele, é neste espaço que a escola precisa atuar, pois, não pode se prender apenas ao que o aluno já sabe, nem desconsiderar esse saber já construído. Assim, quando o que antes constituía uma ZDP é efetivada, essa zona de desenvolvimento proximal passa a constituir um novo NDR e abre outra ZDP e, assim, sucessivamente (VYGOTSKY, 1988)

Nessa perspectiva, a atuação do aluno como sujeito do seu aprendizado parece claro, embora essa ação não aconteça de forma isolada. A autonomia nessa concepção aparenta concretizar-se a cada etapa evolutiva do estudante, e se espera manifestar tanto em termos da construção de conceitos e conhecimentos, como nos procedimentos de busca de novos conhecimentos e a aplicação dos mesmos em situações cotidianas. O sentido de autonomia empregado no contexto da EAD, geralmente aparece como "aprendizagem autônoma”. Acreditamos que esta referência está diretamente ligada ao fato de que os estudantes têm a possibilidade de realizar seus estudos a distância sem, necessariamente, contar com a presença física do professor. Entretanto, vale salientar que a atividade que é realizada de forma autônoma na $\mathrm{EAD}$, foi pensada, planejada, sistematizada e disponibilizada por um ou vários professores. Os meios pelos quais as atividades são disponibilizadas para o aluno sejam material impresso, vídeo, entre outros, provavelmente, envolve a atuação também de outros profissionais. Dessa forma, quando o Projeto Pedagógico dos cursos de licenciatura a distância 
ressalta a independência do aluno em relação ao professor aparenta omitir a interdependência existente entre ambos, mesmo que a interação aconteça à distância. Além disso, sabemos que há participação direta ou indireta de outros profissionais para que o ensino e a aprendizagem à distância possam ser operacionalizados.

Diante do exposto, consideramos que a concepção de aluno na perspectiva sociointeracionista, necessita ser ampliada para contemplar além da ação do sujeito em si, a interação deste com o outro social que possibilita àquele constituir-se como sujeito e como construtor de conhecimento num processo contínuo mediado pela linguagem. Nesse sentido, concebê-lo como um sujeito interativo implica na extensão do olhar em relação ao que realmente ocorre no processo de aprendizado e desenvolvimento humano. Até porque, em se tratando do ser humano, nada pode acontecer isoladamente. A esse respeito, abordando o ato de conhecer numa dimensão libertadora, Paulo Freire ressalta que a "libertação não se dá dentro da consciência dos homens isolada do mundo, mas na práxis destes dentro da história que, implicando a relação consciência-mundo, envolve a consciência crítica dessa relação" (FREIRE, 2006, p. 116). Isso, entretanto, não se limita apenas ao aluno, mas estende-se também ao professor.

O Professor é considerado um orientador no sentido do "aprender a aprender e aprender a fazer". Ao atribuir à ação docente o ato de orientar o processo de aprendizagem, fica evidente a relevância da importância deste possuir um conhecimento amplo em vários campos que tratam dos aspectos fundamentais do desenvolvimento humano. Os fundamentos epistemológicos que buscam esclarecer como ocorre o ato de aprender destacam as relações estabelecidas nesse fenômeno em várias correntes, conforme o campo do conhecimento e cada momento histórico. Este parece constituir um saber indispensável para o docente que, associado ao conhecimento específico da sua área, de métodos e técnicas favoráveis ao fomento da necessidade e vontade de aprender, possivelmente, 
represente a garantia de um trabalho eficiente e eficaz, que realmente potencialize aprendizagens.

Entretanto, segundo Carvalho (2007), comumente se afirma que na Educação a Distância o aluno aprende sozinho, conduzindo autonomamente seu caminho na aquisição do conhecimento. Ela ressalta que isso não condiz com a realidade, pois o papel do professor na educação a distância é tão importante quanto no ensino presencial apesar de sua forma de atuar ser diferenciada. Por outro lado, essa atuação diferenciada, aparentemente, reafirma e reforça o papel do professor diante da necessidade de cada momento compreender melhor a complexidade que envolve o fenômeno educativo. Simultaneamente, emerge a necessidade de elevação da consciência de si, ou seja, a conscientização da importância da sua consciência profissional. Ademais, se na EAD o aluno caminha de forma autônoma na aquisição do conhecimento, significa que alguém ou alguns profissionais se debruçaram durante longo tempo para poder disponibilizar os meios e recursos norteadores do estudo autônomo. Além disso, vale salientar que mediante a implementação da prática educativa nessa modalidade com a imersão das novas tecnologias, também é reforçado o papel do professor como aprendente. Isto se dá porque, na medida em que ensina, está aprendendo continuamente sobre si próprio, sobre o aluno e sobre o mundo que o cerca exigindo, principalmente, outras habilidades como, por exemplo, o manuseio e utilização das novas ferramentas tecnológicas como suporte para o trabalho pedagógico.

O diálogo pedagógico na EAD ou qualquer outra modalidade de educação se caracteriza pela bilateralidade das relações estabelecidas na operacionalização do processo educativo. Esta bilateralidade envolve por um lado os sujeitos entre si, na medida em que ninguém sozinho realizaria algo e por outro lado, esse algo a ser realizado não parte do nada, mas, sim, de situações, fatos e fenômenos concretos que, por sua vez, também constituem objeto dessas inter-relações. Nesse contexto é imprescindível considerar a mediatização das 
mensagens pedagógicas que, na percepção de Belloni (2002), consiste no conhecimento de metodologias de ensino e estratégias de utilização de materiais de ensino/aprendizagem que potencializam ao máximo as possibilidades de aprendizagem autônoma. Desse modo, o trabalho com os conteúdos pedagógicos precisa enfatizar a auto-aprendizagem, ou seja, está "centrado no aprendente, como um ser autônomo, gestor do seu próprio processo de aprendizagem" (BELLONI, 2002, p. 156).

O Conteúdo das disciplinas é distribuído a partir de temas geradores, dos quais a seca é o principal (permeado por sub-temas). Pudemos constatar um aspecto significativo neste modo de tratar os conteúdos que consiste na investigação dos problemas existenciais predominantes na região para a qual os cursos são destinados. Esta estratégia permite a interligação dos saberes cotidianos com os saberes científicos e a atribuição de sentido aos mesmos, favorece a contextualização e a globalização dos saberes. A respeito disso, nos reportamos à idéia da produção de um pensamento "ecologizante", defendida por Morin. Segundo ele, "esse pensamento situa todo acontecimento, informação ou conhecimento em relação de inseparabilidade com seu meio ambiente- cultural, social, econômico, político e, é claro, natural" (MORIN, 2001 apud NEDER, 2005, p.62).

Essas idéias apontam para a concepção de conteúdo como um meio articulador prática-teoria-prática, em que a meta não é o conteúdo em si, mas utilizá-lo para ativar processos intra e intersubjetivos no desenrolar da atividade pedagógica. Isso envolve além do aprender a conhecer, aprender a aprender, aprender a conviver e aprender a ser. Isso é decorrente do fato de que, na medida em que os conteúdos são propostos a partir da realidade concreta dos estudantes, se oportuniza a ação destes sobre os mesmos. Esse aspecto demonstra que o conteúdo é dinâmico, vivo, presente, envolve legado cultural e perspectiva de futuro. A partir de levantamento e reflexão sobre problemas locais, pesquisas diversas, associação de questões locais com questões gerais o estudante exercita habilidades 
fundamentais ao processo de aprendizagem. Nenhuma aprendizagem pode se efetivar sem leitura, interpretação, argumentação, escrita, etc. Por outro lado, ao passo que desenvolve estas habilidades os alunos estão em relação constante com outras pessoas sejam colegas de equipes, professor, tutor, comunidade. Nesse processo, o nível de conscientização da consciência humana é elevado ao ponto de formar uma consciência crítica da realidade existencial e do papel dos sujeitos na construção/reconstrução do mundo. Acreditamos que esse nível de consciência favorece melhor atuação do ser humano enquanto ser social. O fato de o indivíduo ampliar a consciência de si como parte de um todo organizado (sociedade/ natureza) do qual recebe influência e ao mesmo tempo o influencia propicia estabelecer um sentimento de pertença através do qual se sinta co-responsável no processo de construção/reconstrução do conhecimento e do mundo.

Outro fator relevante no sentido de representar uma autêntica inovação no projeto de cursos de Licenciatura a distância da UFRN, é a superação da fragmentação disciplinar. A forma de articular os conteúdos através de temas geradores aproxima os professores das várias disciplinas, integra conteúdos na busca de respostas às perguntas geradoras implicando a construção de conhecimento mais amplo e interdisciplinar. Este aspecto favorece a superação da fragmentação, ou compartimentalização do conhecimento como se este existisse em pedaços, compartimentos isolados e não formando uma verdadeira teia de relações e inter-relações nos seus diversos campos. Até porque o contexto em que se desenvolve o conhecimento é constituído pela natureza, sociedade, cultura, entre outros elementos todos intimamente ligados. Dessa maneira, é fundamental uma concepção clara de cada um desses fenômenos associada a outros elementos tais como o homem e o mundo. É essa concepção que delineia a abordagem de educação na proposta pedagógica de cada instituição de ensino. 
A Abordagem subjacente nos três projetos estudados é fundamentada nas idéias de Paulo Freire busca o resgate de valores e cultura regional sem, no entanto, perder o foco no sentido global do saber científico. Um aspecto interessante em termos do resgate de valores diz respeito ao papel de cada indivíduo no processo educativo. $\mathrm{O}$ assumir-se enquanto sujeito social e histórico envolve a clareza da participação e co-participação de cada um na dinâmica da sociedade como um todo. Isso envolve a certeza de que, na medida em que somos sujeitos, também nos tornamos objeto porque na interação com o meio (físico/social) modificamos esse meio e, ao mesmo tempo, nos modificamos. Essa perspectiva se contrapõe a uma prática educativa centrada no treinamento pragmático, ou no elitismo autoritário de uns que se julgam donos da verdade e do saber articulado que impõe aos outros. Envolve a adoção de práticas descentralizadas permeadas por sentimentos como humildade, tolerância, respeito, solidariedade, entre outros.

A ação educativa articulada nessa ótica, precisa evidenciar a sua intencionalidade e como tal delinear a linha de pensamento e de ação que conduzem a uma visão ampla do processo educativo e do conhecimento em construção/reconstrução. Trata-se de não perder de vista o âmbito em que precisa atuar. Implica em considerar os diversos aspectos que envolvem o fenômeno da aprendizagem bem como o uso social possível. De nada adianta aprender algo se não sabemos de que nos servirá, em quais momentos da nossa vida podemos utilizar esse aprendizado. Mesmo que, aparentemente, esse aprendizado se efetive, rapidamente é esquecido, conforme se pode constatar no ensino pautado na memorização de conteúdos objetivando, apenas, a realização de provas escritas e não a sua aplicação na prática. Assim, para que o diálogo pedagógico potencialize aprendizagens significativas torna-se imprescindível atentar para os meios facilitadores e os materiais didáticos utilizados. 
Neste sentido, passamos a descrever a etapa do trabalho que se caracterizou pela observação da prática pedagógica desenvolvida por meio dos fascículos (mídia impressa) da disciplina Educação e Realidade.

A Disciplina Educação e Realidade: Desvelando a Teoria e a Prática Pedagógica na EAD

Esta disciplina é comum aos três cursos no ciclo de estudos básicos, conforme se pode verificar no quadro de disciplinas do semestre inicial. Tem como ementa: Levantamento da realidade local: caracterização da população e sua origem, formas de organização do trabalho, instituições e organizações sociais, hábitos e costumes, espaços de sociabilidade. Representações sociais sobre clima, chegando a uma primeira identificação de conflitos ambientais. A Educação como realidade social e como uma das formas de transformação social.

Como se pode ver, o conteúdo é voltado para o estudo de problemas da realidade concreta dos cursistas que serve de ponto de partida para os estudos. Por meio da problematização dessa realidade é possibilitada a reflexão sobre os seus problemas principais. Isso favorece a construção de novos conhecimentos tendo como norte a ampliação do conhecimento já adquirido na convivência do dia-a-dia. Mantém o foco na dimensão científica do conhecimento, sem deixar de estabelecer o vínculo deste com a vida, de modo a torná-lo significativo.

Para a análise propriamente dita consideramos os seguintes critérios: a organização geral dos fascículos, a distribuição dos temas geradores, a organização da aula, as atividades pedagógicas e a construção dos conceitos, em torno dos quais buscamos evidenciar características dos processos interativos (instrução e feedback) e a presença de interatividade. 
$\mathrm{Na}$ organização geral, verificamos que a disciplina está distribuída em 15 (quinze) fascículos, cada um correspondendo a dez horas de atividades/semana, totalizando 60 (sessenta) horas. Inicialmente, observando a capa onde aparece o número da aula, o tema e os sub-temas, com exceção de três fascículos de uma $2^{\mathrm{a}}$ edição que, ao invés dos sub-temas, apresenta o nome dos professores autores (fascículos 08, 09 e 14). Além disso, há uma ilustração relacionada ao tema da aula e o slogan do Programa Universidade a Distância.

Todos os fascículos iniciam como uma apresentação do conteúdo da aula retoma conteúdos estudados anteriormente e orienta como o aluno deverá proceder. Em seguida, são destacados os objetivos pretendidos. Através desses elementos o estudante tem uma visão geral do que, como e para que o tema será trabalhado. A seguir, as atividades vão sendo propostas, em número de uma a três, seguidas de questões a serem respondidas, indicação de leituras complementares, um resumo da aula, auto-avaliação, aprofundamento, desafio, referências e anexos. Permeando as atividades são encontrados glossários com palavras e expressões que aparecem em destaque nos textos. Todos esses itens são comuns em todas as aulas, havendo ressalva nas aulas de números 05, 06, 09, 10, 11 e 12 que não disponibilizam anexos. Em relação aos aspectos gráficos observamos a presença de discretas ilustrações em todos os fascículos com páginas de fundo branco e apenas duas cores na distribuição dos textos. Apenas na capa e ilustrações aparece uma terceira cor (cinza). O número de páginas varia entre 12 e 21.

A distribuição dos temas geradores ocorre com o desmembramento do tema central "seca e água" em sub-temas, conforme podemos verificar no quadro 1 . 


\begin{tabular}{|c|c|c|}
\hline Aula & Temas & Subtemas \\
\hline 01 & $\begin{array}{l}\text { O Nordeste: } \\
\text { um mote para o ensino }\end{array}$ & Patativa do Assaré / Visões do Nordeste \\
\hline 02 & $\begin{array}{l}\text { O Município: organizando as } \\
\text { informações }\end{array}$ & Seca e Miséria: iniciando a pesquisa \\
\hline 03 & $\begin{array}{l}\text { O Município: } \\
\text { aprofundando a pesquisa }\end{array}$ & O Tempo e as Mudanças / A Linha do Tempo \\
\hline 04 & As Esferas da Vida Social & $\begin{array}{c}\text { Caracterizando as Esferas / As Relações entre as } \\
\text { Esferas }\end{array}$ \\
\hline 05 & A Formação da Sociedade & Natureza e Cultura/Nomadismo e Agricultura \\
\hline 06 & A Sociedade Capitalista & $\begin{array}{l}\text { A Pobreza e a Produção Capitalista / Revoluções } \\
\text { Industriais }\end{array}$ \\
\hline 07 & $\begin{array}{l}\text { Capitalismo e Desigualdade no } \\
\text { Nordeste }\end{array}$ & O Capitalismo e Índices de Desenvolvimento \\
\hline 08 & Formação do Nordeste11 & * \\
\hline 09 & Nordeste Hoje & * \\
\hline 10 & $\begin{array}{l}\text { Os Diferentes tipos de conhe- } \\
\text { cimento }\end{array}$ & O Conhecimento Sistematizado e do Mundo Vivido \\
\hline 11 & $\begin{array}{l}\text { Conhecimento na Sociedade } \\
\text { Contemporânea }\end{array}$ & A Sociedade Contemporânea - O Global e o Local \\
\hline 12 & Desafios da Escola Hoje & Escola Hoje \\
\hline 13 & O Aluno & Família / Escola / Trabalho \\
\hline 14 & A Aprendizagem e o Ensino & $*$ \\
\hline 15 & Metodologia e Conteúdos & $\begin{array}{l}\text { A Construção do Conhecimento sobre a Localidade / } \\
\text { A Construção do Conhecimento das Diferentes Áre- } \\
\text { as / A Construção do Conhecimento do Educando / } \\
\text { A Dialogicidade }\end{array}$ \\
\hline
\end{tabular}

Quadro 1 - Temas dos fascículos da disciplina

A estratégia utilizada para a escolha dos temas geradores a partir de problematização do contexto social dos estudantes, vem de encontro a um dos primeiros princípios do Instrucional Design (ID), apresentados por MERRIL (2002 apud DIAS et al, 2006), segundo o qual os alunos aprendem melhor se o processo de ensino e de aprendizagem foi orientado para a resolução de problemas reais. Este princípio é comungado por outros autores que apontam para a importância de programar processos e/ou mecanismos 
que estabeleçam a relação entre o conhecimento prévio, permitindo a sua transferência para a situação de aprendizagem atual, também aponta no sentido da interação entre o conhecimento e a experiência, entre outros princípios. Nesta ótica, entendemos que considerar a realidade existencial do aluno no processo de construção do conhecimento, constitui uma maneira de encarar a dinâmica natural dos fenômenos implicados no processo educativo. Acaba por dar vida ao processo de ensino e aprendizagem, tornando-o significativo, útil para o desenvolvimento do homem e da sociedade e isto envolve além da formação de conceitos científicos, envolve a aprendizagem de conteúdos procedimentais (aprender a fazer) e atitudinais (aprender a conviver e a ser).

Nessa perspectiva, trata-se de consolidar formas de, realmente, aprender e continuar aprendendo ao longo da vida e, não apenas, para responder a momentos estanques como se processa no modelo tradicional de ensino no qual o aluno estuda para fazer prova, obter nota, aprovação e certificação, sem, entretanto, fazer nenhum uso social do que supostamente é aprendido. Ainda vale salientar que, dentro desse modelo, o estudo fica limitado à ligação com uma instituição de ensino. Caso se desligue desta, o aluno não continua estudando e aprendendo de forma autônoma até porque não teve oportunidade de tomar consciência nem de exercitar a importância do estudo na sua vida.

$\mathrm{Na}$ organização da aula, observamos que cada fascículo inicia com uma apresentação deixando claro para o estudante a finalidade, os procedimentos que serão necessários e os objetivos pretendidos configurando a consolidação de um processo interativo. Na seqüência, as aulas iniciam a apresentação com um resumo revendo o conteúdo da aula anterior o que, a nosso ver, também reforça esse processo. Esses procedimentos nos apontam duas dimensões de interação: uma voltada para a relação professoraluno visto que deixa explícita para o aluno a idéia de que o texto escrito está dirigido para ele uma vez que antecipa qual será sua 
ação durante a aula o que, de certa forma, aproxima-o do professor. A outra dimensão está ligada a interação por meio do conteúdo que é retomado a cada aula e mantém constantemente relação com o entorno social do aluno. Nesta última, vislumbramos a possibilidade de interatividade, haja vista que os conteúdos não são abordados de modo fechado, deixam margem para intervenção por parte do aluno em consonância com sua realidade. A interatividade para Correia e Antony consiste na construção de um percurso de sentido que envolve a conexão de temas e idéias, "pois o usuário pode interferir e transformar o texto, tornando-se, nesse caso, coautor" (CORREIA; ANTONY, 2003, p. 62).

Assim, ao tempo em que a construção dos conceitos se articula diretamente com o mundo do estudante o torna co-autor, ou seja, sujeito do seu processo de construção de conhecimento, intervindo, decidindo, transformando conceitos que a princípio parecem fictícios em conceitos reais. Isso envolve a compreensão do caráter dinâmico do conhecimento que está em constante movimento conforme cada espaço geográfico e cada momento histórico. Todavia, esses conhecimentos interagem entre si, dando suporte a reconstrução/ construção de novos conhecimentos uma vez que constituem base de reflexão, pois, não se constrói do nada. Toda construção supõe uma base que lhe dê sustentação. A consolidação dessa construção é efetivada por meio das atividades pedagógicas desenvolvidas.

As atividades pedagógicas enquanto suporte de aprendizagens significativas e do desenvolvimento de novas competências envolvem necessariamente a interação e a interatividade que constituem características essenciais do processo de aprendizagem como um todo. A interação consiste em diálogo, troca entre interlocutores e pode ocorrer oralmente, ou por meio de texto escrito. Por outro lado, a interatividade envolve a possibilidade de agir, intervir sobre programas e conteúdo, agir conscientemente, tomar partido, entre outras ações. 
Um aspecto que, a nosso ver, constitui um processo dialógico caracterizado na interação é a maneira como as atividades são conduzidas. Mediada pelo texto escrito, geralmente, há orientações preliminares à leitura dos textos. Essa prática diverge do modelo que costumeiramente se observa em parte dos livros didáticos onde o texto é iniciado sem nenhuma orientação de como o aluno deverá proceder através da leitura. Somente no final do texto é que as atividades são apresentadas fato que, certamente, induzirá o aluno a uma nova leitura do texto. A introdução do texto a partir de uma orientação prévia dos procedimentos necessários é uma forma de antecipar para o aluno o que fará simultaneamente ao ato de leitura. Isso constitui uma forma de otimizar o tempo e facilitar o entendimento inicial do que e como o aluno deve proceder e para que. Em alusão ao texto, enquanto mediador de interação no processo educativo Litwin (2001 apud SOLETIC, 2001, p.78) afirma ser este "o responsável por estabelecer a relação entre os participantes do processo educativo, por despertar o interesse, gerar perguntas valiosas, antecipar dificuldades, apresentar soluções, estimular a agir".

Esse aspecto reforça a teoria vygotskyana da importância da linguagem como impulsionadora da comunicação que se estabelece nos processos interativos de construção de conhecimentos e constituição dos indivíduos de maneira particular. Nesse processo, cada palavra nova apreendida constitui um conceito novo na mente dos sujeitos e amplia a potencialidade do conhecer sempre, em nível cada vez mais complexo. Todavia, a linguagem escrita precisa propiciar uma comunicação fluida entre professores e alunos. Sendo clara, direta e expressiva a linguagem pode transmitir ao estudante a idéia de que ele é o interlocutor permanente do professor e que, conjuntamente, participam da construção de conhecimentos específicos. Nesse sentido, a linguagem possibilita expressar as intenções e preocupações de quem ensina por intermédio dos processos de quem aprende. Simultaneamente, o aluno pode notar que é o próprio docente que lhe apresenta a proposta e indica uma seqüência 
didática a ser seguida, tornando mais evidente a idéia de construção orientada dos conhecimentos. Portanto, dependendo do tipo de interação proporcionada por meio do texto escrito, a atuação do professor embora distante, se torna presente. Nessa perspectiva, ressaltamos a relevância quanto a forma como os textos são introduzidos utilizando pistas e sinalizações a respeito de como o aluno deve encarar a sua leitura, o percurso da seqüência didática, os locais onde pode encontrar mais dados. Além disso, referências constantes a assuntos e atividades já realizadas, mas que é necessário ser recapitulado durante o processo de construção do conhecimento de forma integradora, constitui recursos valiosos.

A construção do conhecimento no material estudado se dá a partir de temas geradores relacionados com a realidade concreta dos cursistas. Para a construção dos conceitos não é utilizado o procedimento de apresentá-los prontos e acabados para o aluno memorizar de forma mecânica. Pelo contrário, ele é induzido a refletir sobre os mesmos, faz uso de várias estratégias para a sua construção de forma cooperativa, estimulando constantemente a pesquisa, a reflexão e o pensamento crítico. Esse procedimento parece dar vitalidade ao processo educativo superando a prática de educação bancária em que o aluno é tratado como receptáculo inerte, desprovido de tudo o que representa vida (emoção, afeto, vontade, consciência). A opção por trabalhar temáticas extraídas de problemas locais para adentrar nos conceitos gerais e conteúdos específicos de cada disciplina, consiste numa estratégia de tornar significativo o conhecimento adquirido. Entendemos que a construção autêntica de conhecimentos se processa mediante a atribuição de sentido aos conceitos/conteúdos trabalhados. Entretanto, isso só é possível se o processo educativo ocorrer interligado à prática social dos aprendizes que, por conseguinte, tornam-se sujeitos interativos nessa construção. Pudemos evidenciar claramente esse aspecto no Projeto Pedagógico de Física, que destaca "O elemento de partida serão conteúdos de Física do cotidiano para concluirmos com conceitos e aplicações da Física 
Contemporânea" (UNIVERSIDADE FEDERAL DO RIO GRANDE DO NORTE, 2004c). Isso envolve a ampliação da construção de conteúdos conceituais para contemplar também a construção de conteúdos procedimentais e atitudinais, ou seja, induz o aluno a aprender a aprender e aprender a ser. Nesse sentido, vale destacar ainda do mencionado projeto, "Pedagogicamente, essa visão considera conteúdo específico e metodologia interligados de uma forma orgânica e indissociáveis desde o primeiro contato do estudante com aqueles conteúdos" (UNIVERSIDADE FEDERAL DO RIO GRANDE DO NORTE, 2004c).

Entendemos, portanto, que essa metodologia de trabalho facilita a formação da consciência crítica dos educandos, propicia aplicarem o conhecimento em novas situações do cotidiano, reconstruí-los e construir novos, continuamente. Trabalhar conteúdos vinculando-os ao entorno social dos estudantes, partindo do sistema micro para o macro, associando-os, parece representar fator importante para nortear as atividades pedagógicas. Até porque favorece a interação dos alunos entre si, com a comunidade e com o conteúdo a partir da construção dos conceitos e do conhecimento de forma autônoma, mas decorrente de ação coletiva, o que é comum no âmbito da EAD. Alguns autores apontam os conceitos de interação e interatividade como determinantes dos fios dialógicos implícitos nessa modalidade educativa. Segundo eles, constituem princípios fundamentais da comunicação enquanto mediadora da interlocução no ensino a distância que, contrapondo a unilateralidade, passa a representar uma modalidade interativa. (BELLONI, 2006; POSSARI, 2005; NEDER, 2005).

\section{A Mídia Impressa como Suporte de Processos Interativos}

A partir da análise dos quinze fascículos constatamos que a mediação didática tem o texto como suporte principal. Este é construído com uma linguagem clara, objetiva, direcionada ao estudante caracterizando assim um permanente diálogo. Esse diálogo também 
é propiciado em relação aos conteúdos abordados, por considerar, constantemente, o conhecimento prévio e a realidade concreta do aluno como ponto de partida para a construção de novos conhecimentos ao longo da disciplina. Isso parece caracterizar um processo interativo viabilizado por uma ação conjunta onde todos os envolvidos no processo educativo tornam-se, de fato, protagonistas. Assim, na medida em que há uma contribuição, de uma forma ou de outra, está se efetivando a troca, o diálogo permanente que, além de envolver os sujeitos, envolve também o próprio conhecimento uma vez que este se sustenta no que já é consolidado e, ao mesmo tempo, abre margem para outros níveis de conhecimento mais elevado. Essa interação entre o conteúdo pode ser evidenciada a cada aula haja vista que na sequënciação das mesmas, a partir da aula 02, inicia a apresentação retomando o(s) conteúdo(s) trabalhado(s) na(s) aula(s) anterior(es). Além disso, observamos que há uma busca de integração dos conteúdos da graduação com o conteúdo trabalhado no Ensino Médio. Pudemos constatar isso em algumas atividades, a exemplo das que transcrevemos a seguir, encontradas no fascículo corresponde à aula 06:

Queijo e cachaça são produtos artesanais comuns no Nordeste desde a época em que o Brasil era colônia portuguesa. Para produzir a cachaça, destila-se a garapa de cana-de-açúcar fermentada até que atinja um certo teor alcoólico; e para o queijo, acrescenta-se ao leite um fermento biológico. Relacione conceitos e teorias de Física, Química e Biologia, aprendidos no Ensino Médio, que explicam esses processos de produção (PAIVA, 2005, p. 6).

Outra atividade encontrada nesta aula:

O final do século XIX e o início do século XX no Brasil foram marcados por mudanças políticas como a Abolição dos Escravos e a Proclamação da República. Retome livros de História do 
Brasil ou o livro O Que é capitalismo (CATANI, 1980) e responda às questões seguintes. 1) Quais eram as principais atividades econômicas do país nessa época? 2) Como elas mudaram no período? (PAIVA, 2005, p. 9).

\begin{abstract}
Encontramos também no item auto-avaliação do mesmo fascículo:
\end{abstract}

Duas das questões propostas nesta aula dizem respeito à retomada de conhecimentos anteriores ao início do curso e sua relação com os temas tratados. Se você teve dificuldades com conteúdos do Ensino Médio, procure o tutor ou consulte a bibliografia disponível no pólo. Se a dificuldade foi em estabelecer a relação com os temas da aula, releia o texto fazendo anotações e procure as leituras complementares (PAIVA, 2005, p.17).

Os três exemplos transcritos nos dão uma visão clara de processos interativos mediados pelo texto escrito. Interações estas, que tanto ocorrem entre conteúdos como entre os sujeitos. No primeiro, ao apresentar o contexto de produção da cachaça e do queijo o aluno é induzido a acionar conhecimentos já construídos para realizar a atividade. Ele é desafiado na sua capacidade de estabelecer relações entre os conteúdos integrando-os. No segundo exemplo, apresenta um contexto das mudanças políticas ocorridas na evolução histórica do Brasil, mas já admite que o aluno precise interagir com livros usados no Ensino Médio. Nesse ponto fica evidente a idéia de que a construção do conhecimento não acontece em momentos estanques, sem nenhuma ligação com etapas anteriores. Pelo contrário, essa construção consiste num processo contínuo em que cada etapa evolutiva está intimamente ligada com etapas anteriores e projeta novas etapas, o que não deixa de constituir uma situação interativa. 
Já no item auto-avaliação, o aluno é respeitado em seu ritmo de desenvolvimento na medida em que, de antemão, lhe é apresentado uma possibilidade de interagir com outros recursos bibliográficos, bem como com outros sujeitos a exemplo do tutor. Acreditamos que toda atividade mediada por leitura implica num processo interativo, haja vista que ler é atribuir sentido e somente se consegue atribuir sentido a algo que mantenha sintonia com o nosso conhecimento prévio e com nossa experiência de vida. Imaginemos a dificuldade extrema que estaríamos encontrando para realizar o presente trabalho se estive ligado a uma área de atuação que não fosse a nossa própria, ou seja, a educação, talvez, nem se conseguiria iniciá-lo. Quanto à interação entre os sujeitos, mesmo que esta não esteja explícita como a proposição para o aluno procurar o tutor no caso de dificuldades, está subjacente em todo processo que envolve ação humana, especialmente ensino e aprendizagem seja em que modalidade for.

Além dessas observações, ressaltamos a interação entre conteúdos das várias disciplinas. Pelos exemplos destacados acima, verificamos que há integração de conteúdos de Física, Química, Biologia, História, que por sua vez se articulam com conteúdos da Língua Portuguesa e da Matemática entre outros. Em relação às duas últimas áreas enfatizamos que nenhum estudo se realiza sem utilizar conhecimentos das mesmas, pois, na verdade, funcionam como instrumentos para a explicação das demais, além de existir como área específica de conhecimento. Sem textos e sem raciocínio lógico-matemático a ciência certamente não se desenvolveria. Outro aspecto que vem à tona com essa interação interdisciplinar é a superação da visão fragmentada do conhecimento. Por meio da forma como os conceitos são trabalhados, é passada a idéia de que o conhecimento científico é, na realidade, inter-relacionado com as várias áreas e que sua fragmentação ocorre apenas com a finalidade de, possivelmente, facilitar o estudo. 
Ainda buscando ilustrar a presença de processos interativos, nos reportamos à aula 09. Na questão de número 3 propõe retomar as visões do Nordeste trabalhadas na $1^{a}$ aula e estabelecer um confronto entre informações de estudiosos da região e informações obtidas através de pessoas da comunidade, na aula "O município - aprofundando a pesquisa". Sabemos que, apesar de serem distintos, esses dois tipos de conhecimentos estão em interação e se retroalimentam. O trabalho com questões atuais e incentivo ao uso de recursos tecnológicos associados às novas tecnologias da informação e da comunicação também evidencia a dinâmica interativa, como pudemos perceber no item "Desafio" desta aula:

A transposição das águas do rio São Francisco, como política para enfrentamento da questão da seca no Nordeste, está causando polêmicas. Consulte os portais indicados a seguir. $\mathrm{O}$ primeiro, do Ministério do Meio Ambiente, mostra políticas sobre a gestão das águas no Brasil. O segundo, do Fórum Social do Nordeste, acompanha a ação e as reflexões dos movimentos sociais da região. Escolha alguns textos disponíveis nos portais e identifique os principais argumentos a favor ou contra a transposição. Identifique nos argumentos as informações técnicas e científicas, os interesses de grupos específicos de pessoas e os impactos ambientais. (PAIVA, 2005, p. 9).

Já na aula 10, encontramos a seguinte questão:

Escolha uma revista como Veja, Isto é ou Época. Selecione um de seus números e analise todas as páginas de uma capa a outra identificando: 1) Quantas propagandas usam termos ou conhecimentos científicos e tecnológicos para justificar a venda de produtos. 
2) Em que tipo de colunas ou artigos há referência a conhecimentos das ciências (PAIVA, 2005, p. 11).

Constatamos que em cada aula há um convite para a ação do aluno, ora com pessoas da comunidade, ora com outros agentes (colegas/tutor) e com outros recursos, a exemplo das questões apresentadas acima. Isso proporciona confirmar nossas hipóteses e estabelecer um confronto, embora de forma sucinta entre os pressupostos teóricos dos projetos pedagógicos dos cursos de licenciatura a distância em Física, Química e Matemática implantados e oferecidos pela UFRN.

\section{Conclusão}

Examinando as idéias explicitadas nos projetos político pedagógicos dos cursos de licenciatura em física, Química e Biologia oferecidos pela UFRN na cidade de Campina Grande/PB, pudemos constatar que, no conjunto, refletem pressupostos condizentes com o paradigma sociointeracionista de educação. Analisamos a repercussão desses pressupostos na prática pedagógica mediada pelo material instrucional impresso. Verificamos que, no geral, há uma estreita ligação entre a teoria e a prática. Isso pode ser confirmado a partir da observação de alguns dados teóricos explicitados nos respectivos projetos pedagógicos que foram confrontados com aspectos observados na prática pedagógica.

Para essa etapa do trabalho priorizamos os itens que se apresentaram mais representativos da abordagem teórica ressaltada, que foram destacados no fichamento documental. Nos projetos estudados foram: tipo de ensino, concepção de aprendizagem, concepção de aluno, concepção de professor, conteúdo e abordagem. Além disso, Meios de aprendizagem e Materiais didáticos. Estes 
últimos constituíram o principal foco da nossa pesquisa, particularmente, a mídia impressa que dá sustentação ao estudo autônomo no decorrer das sessenta horas de atividades na disciplina Educação e Realidade. Selecionamos e transcrevemos algumas atividades que, na nossa concepção, confirmam a transposição teórico-prática.

Verificamos a organização geral dos quinze fascículos, que nos aponta um processo pedagógico voltado para a aprendizagem do aluno. Percebe-se a superação da prática centrada na mera transmissão de conteúdos para uma prática firmada numa relação horizontalizada onde tanto professor como aluno assume o papel de atores e autores. Desliga-se daquela tradicional abordagem de ensino pautada na relação dual professor-aluno, na qual o professor ensina os alunos a copiarem a cópia que ele faz dos autores de livros didáticos e acadêmicos. Passa-se de figurantes para autênticos protagonistas do processo educativo. Além disso, a idéia de construção compartilhada do conhecimento fica evidenciada no encaminhamento das atividades de pesquisa em que a participação de outros agentes sociais é invocada.

Estes são apenas alguns exemplos que nos permitiram afirmar a presença de pressupostos da abordagem sociointeracionista de educação no projeto pedagógico e na prática pedagógica desenvolvidos pela Universidade Federal do Rio Grande do Norte, através dos cursos de licenciatura a distância em Física, Química e Matemática.

Enfim, ressaltamos que esta pesquisa consistiu um recorte, pois são amplos os elementos que compõem o sistema educacional, especialmente, na modalidade a distância que se apresenta atualmente como uma alternativa de democratização do ensino superior. A intenção maior foi contribuir para ampliar o debate e a reflexão em torno da educação como determinada e determinante social. 


\section{Referências}

BELISÁRIO, A. O material didático na educação a distância e a constituição de propostas interativas. In: SILVA, Marco (Org.). Educação Online. São Paulo: Edições Loyola, 2003.

BELLONI, M. L. Educação a distância mais aprendizagem aberta. In: BELLONI, Maria Luiza (org.). Formação na sociedade do espetáculo. São Paulo: Edições Loyola, 2002. . Educação a Distância. Campinas: Autores

Associados, 2006.

BÉDARD, R. O material didático impresso no ensino a distância. In: PRETI, Oreste (Org.) et al. Educação a Distância: sobre discursos e práticas. Brasília: Liber Livro, 2005.

\section{Carvalho, A. B. G. Os Múltiplos Papéis do Professor em}

Educação a Distância: uma abordagem centrada na aprendizagem. In: ENCONTRO DE PESQUISA EDUCACIONAL DO NORTE E NORDESTE, 18., 2007,Maceió. Anais... Maceió: EPENN, 2007. Disponível em: <http://www.anabeatrizgomes.blogspot.com/>. Acesso em: 25 mai. 2008.

CORREIA, Â. Á.; ANTONY, G. Educação hipertextual: diversidade e interação como materiais didáticos. In: MAIA, Carmem (Org.). ead.br: experiências inovadoras em educação a distância no Brasil: reflexões atuais em tempo real. São Paulo: Anhembi Morumbi, 2003.

DIAS, A. B. et al. A colaboração e a avaliação como primeiros princípios do instrucional design em contextos de e-learning. 2006. Disponível em: <http://dspace.feg.porto.ucp.pt:8080/dspace/ handle/2386/64>. Acesso em: 06 abr. 1998

D'AVILA, C. Por uma didática colaborativa no contexto das comunidades virtuais de aprendizagem. In: SANTOS, E. ; ALVES, L. Práticas pedagógicas e tecnologias digitais. Rio de Janeiro: E-papers, 2006. 
FIORENTINI, L. M. R. A perspectiva dialógica nos textos educativos escritos. In: FIORENTINI, L.M.R. et al (Orgs.). Linguagens e interatividade na educação a distância. Rio de Janeiro: DP\&A, 2003.

FIORENTINI, L. M. R. et al. Linguagens e interatividade na educação a distância. Rio de Janeiro: DP\&A, 2003.

FREIRE, P. Pedagogia da autonomia: saberes necessários à prática educativa. São Paulo: Paz e Terra, 1996.

2006.

Ação cultural para a liberdade. São Paulo: Paz e Terra,

LITWIN, Edith (Org.). Educação a Distância: temas para o debate de uma nova agenda educativa. Porto Alegre: Artmed, 2001.

MAIA, Carmem (Org.). ead.br: experiências inovadoras em educação a distância no Brasil: reflexões atuais em tempo real. São Paulo: Anhembi Morumbi, 2003.

NEDER, M. L. C. A educação a distância e a formação de professores: possibilidades de mudança paradigmática. In: PRETI, O. et al. Educação a Distância: sobre discursos e práticas. Brasília: Liber Livro, 2005.

. O processo de comunicação na educação a distância: o texto como elemento de mediação entre os sujeitos da ação educativa. In: PRETI, Oreste (Org.) Educação a distância: ressignificando práticas. Brasília: Liber Livro, 2005.

PAIVA, I. A. de; PERNAMBUCO, M. M. C. A. Educação e Realidade: interdisciplinar. Natal: EDUFRN, 2005.

POSSARI, L. H. V. Educação a distância como processo semiodiscursivo. In: PRETI, O. et al (Org.). Educação a Distância: sobre discursos e práticas. Brasília: Liber Livro, 2005.

PRETI, Oreste et al (Org.). Educação a Distância: sobre discursos e práticas. Brasília: Liber Livro, 2005. 
PROINFO. Informática e formação de professores. Brasília: MEC, 2000.

SOLETIC, A. A produção de materiais escritos nos Programas de Educação a Distância: problemas e desafios. In: LITWIN, E. (Org.).

Educação a Distância: temas para o debate de uma nova agenda educativa. Porto Alegre: Artmed, 2001.

UNIVERSIDADE FEDERAL DO RIO GRANDE DO NORTE. Projeto de Curso de Graduação (Licenciatura) em Matemática, na modalidade a distância. Natal: 2004a.

UNIVERSIDADE FEDERAL DO RIO GRANDE DO NORTE. Projeto de Curso de Graduação (Licenciatura) em Química, na modalidade a distância. Natal: 2004b.

UNIVERSIDADE FEDERAL DO RIO GRANDE DO NORTE. Proposta Político-Pedagógica para Curso de Graduação a distância (Licenciatura em Física). Natal: 2004c.

VALENTE, J. A. Educação a distância: uma oportunidade para mudança no ensino. In: MAIA, C. (Org.). ead.br: experiências inovadoras em educação a distância no Brasil: reflexões atuais em tempo real. São Paulo: Anhembi Morumbi, 2003.

. Praticando e aprendendo sobre educação a distância: as experiências do NIED. In: MAIA, Carmem (org.). ead.br: experiências inovadoras em educação a distância no Brasil: reflexões atuais em tempo real. São Paulo: Editora Anhembi Morumbi, 2003.

VYGOTSKY,L. S. A formação social da mente: o desenvolvimento dos processos psicológicos superiores. 5 ed. São Paulo: Martins Fontes, 1994.

VYGOTSKY,L. S. Pensamento e linguagem. 3. ed. São Paulo: Martins Fontes, 2005. 


\title{
As concepções de interatividade nos ambientes virtuais de aprendizagem
}

\author{
Maria das Graças Barros \\ UEPB - Campina Grande, Paraíba \\ galbarros2@hotmail.com \\ Ana Beatriz Gomes Carvalho \\ UEPB- Campina Grande, Paraíba \\ anabeatrizuepb@gmail.com
}

\section{Introdução}

Sabemos que o avanço da tecnologia tem influenciado a economia mundial, e por conta disso, as relações de mercado e pessoais já não são mais as mesmas. Hoje, as relações giram em torno do consumo, da competitividade e da competência. Uma nova ordem se levantou: da globalização ou mundiatização, da interconectividade, da informação. A nova era da Sociedade da Informação exige maior rapidez e demanda quantidade de informação, o que nos leva a elaborar outros olhares e a eleger novos interesses. Portanto, em face dessas mudanças as instituições também tentam se adequar para atender às exigências atuais. 
É nessa perspectiva, que pensamos a educação. Educação de qualidade e inclusiva, a que deva preparar o indivíduo para interagir com o meio com maturidade, autonomia e criticidade, ou seja, aquela que prepare o indivíduo para compreender e intervir em prol de uma sociedade mais humana, sem se deixar excluir, ou mesmo, se deixar levar pela enxurrada de informações que as mídias produzem.

A Educação a Distância (EAD) é uma modalidade que tem ao longo da história se transformado e com isso se colocado como uma alternativa para os dias atuais. Se no início, ela se prestava apenas a atender aos interesses econômicos vigentes na sociedade, de tal forma que o ensino era meramente unilateral (ensino por correspondência), e focado na tecnologia utilizada para tal veiculação (correios, rádio), vencer a barreira da distância e qualificar massivamente a população eram seus objetivos. Hoje, porém, a educação a distância amplia-se juntamente com as novas tecnologias e agrega novos valores pedagógicos e, por isso, pode constituir-se, como já foi dito, numa alternativa para inclusão social.

Um dos fatos que justifica o nosso interesse por Educação a Distância é acreditar que esta modalidade apresenta características que podem ajudar a superar e romper algumas formas de exclusão. Uma delas é que a EAD surge rompendo a barreira do tempo e do espaço. A pessoa conectada em uma rede, por intermédio da internet, pode receber informações, pesquisar e produzir conhecimentos, atendendo a um dos princípios do ensino a distância que é a flexibilidade, que segundo Belloni (2006) possui diferentes acepções que vão desde a flexibilização do acesso, flexibilização do ensino, da aprendizagem e até a da oferta.

Tendo em vista a Educação a Distância utilizar-se de ferramentas tecnológicas para a realização do processo de aprendizagem, compreender esse papel na mediação pedagógica, constitui-se num debate que se amplia para o questionamento: até que ponto as ferramentas tecnológicas, promotoras de aprendizagem colaborativa, 
oportunizam aos alunos de Administração a Distância a ressignificação do conhecimento, ou seja, oportunizam uma relação de construção de significados.

Portanto, este trabalho tem por objetivo geral analisar o Ambiente virtual de aprendizagem enquanto plataformas integradoras de ferramentas tecnológicas e pedagógicas, propiciadora de aprendizagem, dando destaque às interfaces tecnológicas interativas.

Como objetivos específicos, pretendemos investigar as ferramentas pedagógicas disponíveis no Ambiente Virtual de Aprendizagem - Moodle; analisar os instrumentos das NTIC que são potencializadores e quais são os inibidores, a partir do conceito de interatividade e identificar possíveis dificuldades dos alunos do curso de Administração a distância da UEPB no uso das ferramentas de aprendizagem colaborativa e ao mesmo tempo buscar indicadores que apontem para a superação dos obstáculos e disseminação das soluções.

\section{Educação a distância e as Novas Tecnologias de Informação e Comunicação}

Educação, segundo o dicionário de Aurélio, diz respeito "ao processo de desenvolvimento da capacidade física, intelectual e moral da criança e do ser humano em geral, visando à sua melhor integração individual e social" (FERREIRA, 1986, p. 499). Todavia, para que seja efetivada a integração entre pessoas, e para a promoção intelectual e física do ser humano é necessário que técnicas sejam criadas para a realização dos eventos que promovam a sua ascensão.

Para a educação assistemática, os conhecimentos são passados oralmente ou escrito de pessoas para pessoas, de geração para geração. Já os conhecimentos sistematizados são transmitidos em um ambiente físico fechado, a partir de sugestão de conteúdos 
que imaginamos atenderem às necessidades daquela faixa etária. Nestes casos, o uso de tecnologia tem sido incorporado para que as ações educativas sejam concretizadas. Em um primeiro momento, fez-se necessário a invenção dos livros, jornais, revistas, a partir do advento da escrita. Mais adiante, o rádio, o telefone, a televisão se transformaram em instrumentos tecnológicos que viabilizaram uma educação que ultrapassaram as paredes de uma escola tradicional. A educação começa a ser oferecida para além do espaço e do tempo com a ajuda da tecnologia. Hoje, a educação a distância, com a ajuda das NTICs, permite, através da internet, que as pessoas se comuniquem sincrônica ou assincronicamente, formando uma rede de comunicação e aprendizagem colaborativa.

Nesse sentido, a Educação a Distância é considerada uma alternativa para a Educação, justificada sua implantação no Brasil pelo alto índice de analfabetismo, a baixa escolaridade da população, a qualificação profissional deficitária e a sua grande extensão territorial do país. Para Moran (2002) a EAD é o "processo de ensino-aprendizagem, mediado por tecnologias, onde professores e alunos estão separados espacial e/ou temporalmente". Esse conceito nos remete ao contexto sócio-histórico que demandou a possibilidade de oferecer educação a pessoas que estavam distantes dos grandes centros acadêmicos e/ou não tinham disponibilidade de freqüentar diariamente uma escola. Nessas condições, as novas tecnologias chegam para suplantar o problema da distância e atender, portanto, às necessidades dessas pessoas.

Entretanto, essa modalidade de ensino almeja e concretiza mudanças que vão de uma educação baseada na transmissão da informação, na instrução, para a criação de ambientes de aprendizagem, onde o aluno realiza atividades e constrói o seu conhecimento. Com as NTICs, uma nova prática de Educação a Distância ocupa lugar de destaque na pedagogia, uma vez que possibilita flexibilidade do tempo, quebra as barreiras espaciais, emite e recebe instantaneamente materiais, e, sobretudo, potencializa, através da 
interatividade e interação, a comunicação entre pessoas e a construção de conhecimento. Segundo Silva (2003) com o avanço da tecnologia teremos tanto a massificação de boa parte dos cursos superiores como novas formas de aprender continuamente.

Essa é a perspectiva da Educação a Distância, que junto com o avanço da tecnologia, permite-nos prognósticos que vão além do que é real hoje. No entanto, ela é uma realidade que se impõe perante a sociedade como uma alternativa que atuará justamente onde o ensino presencial não consegue atender, ou ainda, atuará como um elemento a mais no ensino presencial, o qual pode ser beneficiado pelas interfaces que permitem a pesquisa e a construção coletiva da aprendizagem.

De acordo com Primo (2000 apud FERREIRA; BIANCHETTI, 2002, p. 260) "[...] as novas tecnologias da informação e da comunicação vêm contribuindo para a modificação da forma de as pessoas se relacionarem e de construírem conhecimentos, pois elas proporcionam múltiplas disposições à intervenção do interagente". $\mathrm{O}$ fato de as pessoas poderem expor seus trabalhos na internet $\mathrm{e}$ receber comentários sobre eles; de produzir textos colaborativamente, de participar de comunidades virtuais que oportunizam participação por temas de interesse, de discussões virtuais, de comunicação instantânea, de espaços para divulgação individual e coletiva, corroboram com as idéias do autor supracitado, e permite acrescentar que as NTICs surgem como suporte para a EAD apresentar uma proposta de integração, potencializada por meio de diversos dispositivos disponíveis, atualmente.

Para tanto, temos que considerar o fato de vivermos em um país de muita desigualdade social, que tem um número elevado da população sem acesso a computadores e muito menos à internet. Políticas públicas têm sido realizadas nesse sentido. O governo tem enviado equipamentos para as escolas, mas ainda falta mão de obra qualificada para técnica computacional e, sobretudo, professores preparados pedagogicamente também para o uso da tecnologia na 
educação. A maioria dos professores não faz parte dessa geração tecnológica, e, por isso, têm muita resistência para compreender essas inovações. Mas, é o professor que deve exercer a função de orientar os alunos quanto ao uso e caminhos a serem trilhados com as novas tecnologias.

Portanto, é importante compreender que os desafios da EAD são equivalentes aos desafios do sistema educacional em sua totalidade, o que implica em analisar a educação que pretendemos realizar, para quem dirigimos, com quem será desenvolvida, com o uso de que tecnologias e que abordagens mais adequadas devem ser exploradas para acelerar o processo de inclusão social da população brasileira.

\section{Ambiente Virtual de Aprendizagem: 0 Moodle}

Para a promoção de cursos a distância, ambientes virtuais estruturados são desenvolvidos com o objetivo de promover a aprendizagem. São espaços eletrônicos construídos para permitir a veiculação e interação de conhecimentos e usuários, Esses ambientes são chamados de Sistemas de Gerenciamento de Aprendizagem (do inglês: Learning Management Systems - LMS). São softwares projetados para atuarem como salas de aula virtuais e têm como características o gerenciamento de integrantes, relatório de acesso e atividades, promoção da interação entre os participantes, publicação de conteúdos.

Os LMS são Ambientes Virtuais de Aprendizagem (AVA), que diferentemente de outros, oferecerem características de controle e gerenciamento inexistentes em outras interfaces da web. Os ambientes de aprendizagem se caracterizam e se diferenciam de outros ambientes da web porque eles têm uma dinâmica própria para atender ao fazer pedagógico, o qual é orientado no sentido de que se estabelecem metas para o aluno atingir. Outro diferencial é o oferecimento de feedback. O feedback é fundamental para que os 
alunos possam avaliar se estão atingindo os objetivos estabelecidos para o curso. Objetivos orientados a feedback são um dos aspectos críticos de um ambiente de aprendizagem, pois, se o aluno não recebe comentário sobre as atividades que ele desenvolveu em um curso ele não tem como saber se está ou não atingindo os objetivos estabelecidos.

Nos AVA's, os recursos que dão suporte à educação a distância são os mesmos da internet: correio, fórum, chat, conferência, banco de recurso. $\mathrm{O}$ gerenciamento desses ambientes engloba diferentes aspectos, dos quais destacamos a gestão das estratégias de comunicação e mobilização dos participantes, a gestão da participação dos alunos por meio de registro das produções, interações e caminhos percorridos, a gestão de apoio e orientação dos formadores aos alunos e a gestão da avaliação.

Apresentamos o Moodle, neste trabalho, por ser o ambiente de aprendizagem, utilizado na maioria das universidades públicas, inclusive pela Universidade Estadual da Paraíba para viabilizar seus cursos a distância, objeto de nosso estudo.

Pelo fato de ser um software livre, gratuito e aberto, o Moodle pode ser carregado, utilizado, modificado e distribuído. Ele é um projeto de desenvolvimento contínuo, por isso, podemos receber atualizações constantes, tendo também os próprios usuários como seus construtores. Por propor uma aprendizagem colaborativa on-line, ele é considerado um ambiente baseado numa proposta sócio-construtivista. Segundo o seu criador Martin Dougiamas, que lidera o projeto até hoje, "não se trata a aprendizagem como atividade social, mas focaliza a atenção da aprendizagem que acontece enquanto construímos ativamente artefatos (como textos, por exemplo), para que outros vejam ou utilizem" (MUZINATTI, 2005).

Sendo assim, o Moodle é um ambiente que permite a adequação das necessidades das instituições e dos usuários, e, enquanto ambiente virtual de aprendizagem, foi desenvolvido levando em 
consideração que a aprendizagem acontece, através da colaboração do conhecimento. Percebemos aqui na filosofia do desenvolvimento do Moodle uma clara expressão das intenções de promover a colaboração e cooperação do outro para com o outro, buscando desenvolver uma cultura baseada em conhecimentos compartilhados entre o grupo.

O fato de o Moodle ser um ambiente de aprendizagem que possibilita o feedback, a própria construção do ambiente e a construção do conhecimento compartilhado conduz que se adote uma concepção social para a compreensão de sua dinâmica de aprendizagem. Pulino Filho (2005, p. 6) comenta a esse respeito que o "termo processo social sugere que a aprendizagem é alguma coisa que se faz em grupos. Deste ponto de vista, aprendizagem é um processo de negociação de significados em uma cultura de símbolos e artefatos compartilhados"

Para o desenvolvimento das atividades são utilizados recursos que reforçam os princípios sóciointeracionistas pelo fato de oportunizarem a comunicação e a intervenção do usuário durante o processo. Esses recursos são disponibilizados no ambiente e oportunizam a interação dos alunos com os conteúdos e com colegas e professores.

Essas ferramentas são consideradas de informação e comunicação. No caso das interfaces de comunicação destacam-se as ferramentas de interatividade síncronas e as assíncronas. As ferramentas de comunicação síncronas são as que permitem a participação de alunos e professores em eventos marcados, com horários específicos, via internet, a exemplo dos chats. Para esse tipo de interatividade, a comunicação em tempo real, possibilita aos envolvidos uma sensação de grupo, de comunidade, o que pode ser determinante para a continuidade do curso, uma vez que preserva a motivação, a interação em tempo real, o retorno e a crítica imediata, encontros regulares, etc. Já as ferramentas de comunicação assíncronas como o Fórum, o Diário, o diálogo, a lição, entre 
outros, são consideradas como revolucionárias pelo fato de possibilitar que o usuário faça sua intervenção de forma mais organizada, uma vez que ele terá tempo para sistematizar sua opinião, comentário, respostas, etc.

Cada uma dessas ferramentas tem uma função definida no ambiente e com possibilidades limitadas e cabe ao professor selecioná-las, conforme os objetivos de seu curso. Todavia se acrescenta que como o Moodle é um ambiente de construção pública e livre, ele pode ser alterado e novas ferramentas podem surgir e serem agregadas a já existentes.

As ferramentas mais comuns no ambiente Moodle são as seguintes: arquivo de Materiais, Lição, Fórum, Tarefa, Questionário, Chat, SCORM, Glossário, Pesquisa de Opinião, wiki, Pesquisa de Avaliação, Diário, Diálogo

O emprego das NTICs na educação possibilita a criação de ambientes novos com estruturas flexíveis, abertas, integrando várias mídias e possibilitando a interação entre os participantes do processo. Mas o uso da tecnologia reforça a existência de um projeto educativo com definição de perfil de alunos, objetivos, parâmetros pedagógicos, conteúdo e avaliação dos conteúdos que serão ministrados, além de ajustes no decorrer do processo ensinoaprendizagem. E o grau de interatividade presente nelas vai, em muito, depender da mediação pedagógica que subjaz ao processo de ensino e aprendizagem a que se propõe o curso, o professor.

\section{Na interatividade pela interação}

O ensino a distância on-line tem sido divulgado como uma alternativa que se configura hoje pela inserção das novas tecnologias de informação e comunicação e junto com elas a idéia da interatividade. Conceito que vem sendo muito discutido, pelo fato de amparar valores e concepções que têm variado no tempo e na história. 
Silva (2006) tem contribuído bastante com o debate nacional sobre interatividade, quando apresenta algumas posições de autores, sobretudo, quando ele apresenta o debate que se travou na França em meados dos anos 80 sobre o termo interatividade. Embates que reconheciam a complexidade e a importância do termo. Ele aponta três reações freqüentes ao termo "interatividade": a primeira como oportunista, ou seja, como modismo, nome novo para coisas velhas. A segunda como estratégia de marketing para expansão do mercado e a terceira como uma estratégia de dominação da técnica, que promove a regressão do homem à condição de máquina.

Mas para Silva, (2006) a terminologia interatividade surge para atender a uma nova modalidade comunicacional, a interativa, que se caracteriza pelo modo dialógico com que os usuários interagem uns com os outros. A interatividade é vista como um fenômeno que emerge da Sociedade da Informação, que para Assmann (2005, p. 16) "é a sociedade que está atualmente a constituir-se, na qual são amplamente utilizadas tecnologias de armazenamento e transmissão de dados e informação de baixo custo". Assmann (2006) também acredita que apenas a disponibilização da informação não caracteriza a Sociedade da Informação, mas o diferencial e o que é mais importante "é desencadeamento de um vasto e continuado processo de aprendizagem” (ASSMANN, 2006, p.16).

Assim, dizemos que as novas tecnologias que permitem a interatividade também promovem uma nova relação do aluno com o conhecimento, com outros alunos e com o professor, a partir do momento, em que se propõe um ensino que considera como prioridade as formas de aprendizagens e, conseqüentemente, os aprendentes. A possibilidade de interagir, através das ferramentas tecnológicas, implica rever todos os papéis dos envolvidos no processo ensino e aprendizagem e como também a metodologia utilizada para a promoção dessa aprendizagem. 
O papel do professor se amplia. Ele deve promover, por força de uma intervenção pedagógica, a autonomia do aluno, no sentido de ajudá-lo a reelaborar o conhecimento existente. Ao professor cabe o papel de promotor-interventor. Silva (2006) acrescenta que o professor na perspectiva da interatividade deixa de ser o contador de histórias, conselheiro, parceiro ou mesmo facilitador e passa a ser um sistematizador de experiências.

Os alunos, desta forma, deixam de aprender passivamente, como acontece com o ensino instrucionista, em que a máquina ou o professor transmitem ou repassam as informações, e passam a exigir mais, tanto dos proponentes quanto de si mesmos, exigindo liberdade e autonomia. Autonomia que, para Morin (1995 apud ASSMANN, 2005), significa o estabelecimento das relações que o aluno construir com o mundo exterior e os outros.

Se por interação entendemos ação recíproca que se estabelece entre pessoas ou coisas, Primo e Cassol (1999, p.67) afirmam que "interação são as relações e influências mútuas entre dois ou mais fatores, de modo que cada um altera o outro e a si próprio, bem como a relação existente entre eles".

Na visão sóciointeracionista, o homem constitui-se como tal, por meio de suas interações sociais, portanto, ele é visto como alguém que transforma e é transformado nas relações produzidas em uma determinada cultura. $\mathrm{Na}$ interação com o outro e com o meio, o indivíduo se deparará com situações conflitantes, que exigirão que ele encontre as possíveis soluções, o que possibilitará a aprendizagem e conseqüentemente, o seu desenvolvimento intelectual.

No contexto de $\mathrm{EAD}$, o favorecimento da interação é marcada pela ação dialógica entre o sujeito e a técnica. Para Hodgson (2001apud VAN DER LINDEN, 2005, p. 63) "o termo interação ao ser incorporado pela internet, transmuta-se em interatividade, traduzindo-se num tipo singular de interação". 
Com as tecnologias disponibilizadas, a educação a distância oportuniza, portanto, maior interatividade entre professor e aluno, alunos e alunos, todos e máquina, ampliando, renovando e construindo conhecimentos porque as novas tecnologias comunicacionais permitem ampla liberdade para o usuário fazer as conexões que lhe forem convenientes, de forma a atualizarem-se e de produzirem as intervenções que mais lhe convierem.

Assim, temos um movimento entre interação e interatividade que vai além do humano e máquina, uma vez que a interação é relação necessária entre sujeito e objeto para a aquisição do conhecimento e interatividade condição sine qua non para a acessibilidade à comunicação em rede, conseqüentemente, essas relações estão tão imbricadas, que uma não se diz sem a outra em EaD.

Investir na interatividade significa investir em novos caminhos, em novos desafios, que serão superados no fazer coletivo, na superação individual. A educação a distância, que oportuniza instrumentos tecnológicos para aproximar pessoas, para garantir a reelaboração do conhecimento e o acesso ao conhecimento científico, tem como objetivo preparar o indivíduo para a vida, para intervir no mundo de forma madura e autônoma, autonomia no sentido de compreensão, de poder de decisão e de escolha e ainda de construção. Que esse indivíduo compreenda que ele faz parte de uma sociedade, que se transforma e que ele, enquanto agente dela, tem que estar preparado para acompanhar e participar dessas transformações.

Assim sendo, a proposta de Educação a Distância que pretende a promoção do ensino, ensejando que o aluno aprenda com as novas tecnologias interativas, pretende sim a sua promoção social, por meio da interação pela interatividade. O conceito de interatividade, como mais um recurso para a intervenção do aluno no processo de aprendizagem, de forma que a sua participação possa influenciar outros e a si mesmo. Todavia, caberá ao professor pesquisar e propor situações e/ou atividades que levem em consideração os 
recursos que a tecnologia oferece para ampliar o mundo do aluno, numa perspectiva de reconstrução e de aprendizagem colaborativa. Silva (2006) acrescenta que as novas tecnologias interativas permitem a participação, a intervenção, a bidirecionalidade e a multiplicidade de conexões.

\section{A influência de Vygotsky para uma teoria de aprendizagem em EAD}

O processo de aprendizagem pelo qual o sujeito passa quando está diante de um objeto de conhecimento pode ser observado sob várias concepções, todavia, quando se entende que a aprendizagem é um processo ativo que conduz a transformações no homem, o olhar se desvia para uma orientação em que o processo se estabelece pelas relações, sobretudo, pelas relações sociais. Esta idéia nos remete a Vygotsky (1998), para quem a questão da relação entre os processos de desenvolvimento e de aprendizagem é central. Mas é o aprendizado que possibilita o despertar de processos internos de desenvolvimento, ou seja, o aprendizado precede o desenvolvimento. Quanto mais se oferece à criança mais chance ela tem para se desenvolver.

Com base nos estudos de Vygotsky (1998), apresentamos alguns conceitos que são fundamentais para que se compreenda a formulação da concepção sóciointeracionista e sua influência para a educação, em especial, para a educação a distância. A teoria da dupla formação das funções psicológicas superiores, a internalização, a mediação e a zona de desenvolvimento proximal.

As funções psicológicas superiores, que compreendem a consciência, a intenção e o planejamento, dizem respeito ao estabelecimento das relações sociais que aparecem, primeiramente sob a forma de processos intermentais, ou interpessoais, que significa que o conhecimento se dá entre as pessoas, num contexto externo para depois passar para processos intramentais ou individuais, o processo é, neste caso, interno. 
Portanto, é do social para o individual que o homem se constitui, de fora para dentro, o que significa dizer que o homem tem características próprias, mas necessita da experiência do outro para viver melhor. Já para o entendimento do processo de internalização compreende-se que a aprendizagem se dá mediante a reconstrução interna de uma operação externa, ou seja, quando o sujeito consegue reconstruir um conhecimento existente, resultado dos processos interpsicológico e intrapsicológico.

Todos esses processos cognitivos têm como base a mediação: enquanto sujeito do conhecimento o homem não tem acesso direto aos objetos, mas acesso mediado, através de recortes do real, operados pelos sistemas simbólicos de que dispõe, portanto enfatiza a construção do conhecimento como uma interação mediada por várias relações.

Por último, destacamos o conceito da zona de desenvolvimento proximal, como um dos níveis de desenvolvimento pelo qual a criança passa no processo de aquisição do conhecimento e que serve para indicar o nível de desenvolvimento em que se deve intervir para que a criança avance e aprenda o conhecimento em potencial.

Segundo Oliveira (1999, p. 59), para Vygotsky (1998), a capacidade de a criança realizar tarefas sozinha representa o nível de desenvolvimento real, que representa resultado de processos maduros. Neste nível, a criança já tem consolidado o conhecimento. Já o nível de desenvolvimento potencial, significa o conhecimento que está por vir, aquele que pode ser internalizado, e que foi detectado na zona de desenvolvimento proximal. Representa o conhecimento que pode ser alcançado com a ajuda do outro, de um colega, pais, professores, ou mesmo, por qualquer objeto sócio-cultural. Por isso, as potencialidades do indivíduo devem ser levadas em conta durante o processo de ensino-aprendizagem, como forma ativar os seus esquemas cognitivos ou comportamentais nas variadas situações de aprendizagem. 
Para Vygotsky (1998), a interação social exerce um papel fundamental no desenvolvimento cognitivo, uma vez que ele parte do princípio de que o desenvolvimento das formas superiores do comportamento (pensar, relacionar, analisar, comparar, etc) pressupõe o aprendizado, que essencialmente cria a zona de desenvolvimento proximal, ou seja, o aprendizado desperta vários processos internos de desenvolvimento, que são capazes de operar quando o sujeito interage com outros em seu ambiente e quando em cooperação com seus companheiros. O aprendizado adequadamente organizado resulta em desenvolvimento mental e põe em movimento vários processos de desenvolvimento que, de outra forma, seriam impossíveis de acontecer.

Em termos gerais, Vygotsky (1998) trouxe para a educação reflexões que permitem pensar a prática pedagógica sob ótica da aprendizagem. Para ele a concepção de ensino e aprendizagem inclui, por um lado, a idéia de que quem ensina e quem aprende não se refere necessariamente a situações em que haja um educador fisicamente presente e que a presença do outro social pode se manifestar por meio de objetos, do próprio ambiente, dos significados que rodeia o mundo cultural do indivíduo. (OLIVEIRA, 2003)

Neste contexto sóciointeracionista, vislumbramos a Educação a Distância como uma modalidade que se utiliza de dinâmicas participativas de cooperação e de comunicação, regras flexíveis, do desenvolvimento da criatividade e da individualidade. O aluno é quem constrói seu próprio conhecimento, sendo auxiliado pelo Tutor/Professor, que o ajuda, instiga-o a avançar e a aguçar a curiosidade. Acompanha o processo de construção do conhecimento do aluno, sempre atento ao fato de que cada ser humano tem sua forma peculiar de aprendizagem, exercendo, assim, papel de mediador da aprendizagem.

Esta teoria pode ser aplicada em EAD, pois respeita o ritmo do aluno, considerando-o como um ser único, sendo ele, aluno, o sujeito da aprendizagem. 
O fato de o ensino e a aprendizagem serem veiculados e processados por uma máquina, não minimiza, como já foi dito, o papel do professor, que nesta propositura tem a função de mediador e, portanto, será responsável pelo material didático postado no ambiente virtual. De acordo com a concepção sóciointeracionista, o material deverá ser atrativo, favorecer o questionamento, a reflexão e, conseqüentemente, a reelaboração do conhecimento. Também, deverão prezar pela interação entre os colegas e, por conseguinte, pela socialização do conhecimento. A aprendizagem é, pois, vista como atividade de elaboração conceitual em um ambiente caracterizado pela interação.

As atividades propostas para a educação a distância, portanto, devem considerar a questão da capacidade individual do aluno e por isso, oferecer atividades que venham a contribuir com o seu avanço intelectual. Para tanto, deve-se propor atividades que permitam o feedback, a devolutiva com as orientações necessárias, de forma que o aluno seja obrigado e motivado a repensar o conhecimento existente. A proposta deve ser desafiadora e problematizadora. $\mathrm{O}$ professor, enquanto mediador, deve avaliar o aluno, a partir de sua capacidade de entendimento e de sua produção oral e escrita. Os conteúdos propostos devem considerar o contexto sócio-históricocultura, no qual estão inseridos os alunos, e os objetivos do curso.

Entendemos, pois, que no dizer de Vygotsky (1998), como a aprendizagem impulsiona o desenvolvimento, a escola tem um papel essencial na construção do ser psicológico e racional. A escola deve dirigir o ensino não para etapas intelectuais já alcançadas, mas sim para estágios de desenvolvimento ainda não incorporados pelos alunos, funcionando como um incentivador de novas conquistas psicológicas. Assim, a escola tem ou deveria ter como ponto de partida o nível de desenvolvimento real da criança (em relação ao conteúdo) e como ponto de chegada os objetivos da aula que devem ser alcançados, ou seja, chegarem ao potencial da criança. "Aqui o professor tem o papel explícito de interferir na zona de 
desenvolvimento proximal dos alunos, provocando avanços que não ocorreriam espontaneamente" (OLIVEIRA, 1999, p. 62).

\section{A pesquisa de campo}

Os procedimentos metodológicos para a realização desta pesquisa consideraram a dinâmica e organização do curso em questão - Administração a distância, que é viabilizado, nos 4 Pólos, que dão suporte à operacionalização do curso. O Pólo de Campina Grande é considerado uma amostra representativa do universo dos alunos do curso por ser composto por 5 turmas, que perfazem um total de 150 alunos.

A pesquisa foi executada sob a abordagem quantitativa e qualitativa por conta das análises descritivas, comparativas e interpretativas, que estão comprometidas com o caráter social da pesquisa, "construção da ciência é um fenômeno social por excelência” (LÜDKE; ANDRÉ, 1986, p. 19).

Com o objetivo de analisar o Ambiente Virtual de Aprendizagem, enquanto plataformas integradoras de ferramentas tecnológicas e pedagógicas, propiciadora de aprendizagem, dando destaque às interfaces tecnológicas interativas, aplicamos, num primeiro momento, um questionário que versava sobre a contextualização do sujeito e sua relação com o ambiente de aprendizagem; sobre a relação de interatividade permitida pelas ferramentas. Em seguida, uma entrevista estruturada com o objetivo de aprofundar algumas idéias não esclarecidas pelo questionário. Das dez questões do questionário, discutiremos apenas duas, face sua importância para a temática que ora discutimos.

Para a primeira questão: que ferramenta(s) disponível no AVA para resolução das atividades permite maior interatividade? Observamos que todas as ferramentas listadas foram consideradas pelos alunos, como interativas. Todavia, o Fórum foi assinalado por $69,2 \%$ 
dos alunos como a ferramenta que permite maior interatividade. Tarefa foi indicada por $41,0 \%$ dos alunos. Chat por $38,5 \%$ deles, e Questionário, 20,5\% dos alunos indicou também como uma ferramenta que permite maior interatividade.

Diante desse resultado, foi necessário saber dos alunos o que eles entendiam por interatividade, e porque eles consideraram determinadas ferramentas como interativas, haja vista todas as ferramentas terem sido apontadas como interativas. Para Fórum, justificaram que ela permite maior interatividade porque:

a) Pode-se obter respostas do professor, trocar idéias com outros alunos e promove o debate;

b) Permite a construção do conhecimento;

c) Ela dá vez ao aluno para opinar e ver a opinião dos outros, permite a troca de experiência;

d) Permite o feedback;

e) Permite a comunicação entre professor e aluno.

O Chat foi a ferramenta que recebeu o comentário de que a interatividade acontece pela possibilidade da comunicação síncrona, em tempo real, e por ser uma ferramenta dinâmica.

Já com relação às ferramentas Tarefa e Questionário, as justificativas elegem o feedback com as notas e comentários do tutor como principais fatores que contribuem para a interatividade. No entanto, uma aluna chama a atenção para a forma como as ferramentas - Questionário e Tarefa - são apresentadas: de forma coercitiva temos que usar por conta da avaliação, mas pela interatividade são gostosas.

Quanto ao que os alunos entendem por interatividade, eles foram claros em suas ponderações e entendem por interatividade 
o ato de comunicação entre pessoas, mesmo quando se valiam de outras expressões como: troca de informação, ação desenvolvida entre duas pessoas, contato entre pessoas, troca de experiência, troca de conhecimentos, interação entre pessoas.

Segunda questão: das disciplinas oferecidas, nos dois últimos semestres, que utilizaram ferramentas e que favoreceram a aprendizagem na opinião dos alunos foram: Informática Básica II com 71,8\%, Informática Básica I com 51,3\% e Sistema de Informação com $53,8 \%$. As demais disciplinas apresentaram percentuais abaixo de $36 \%$.

Para esta questão, quisemos saber, por meio da entrevista porque estas disciplinas foram consideradas como as que ofereceram ferramentas que melhor contribuíram para aprendizagem. As justificativas variam também. Para Informática I e II, as disciplinas mais representativas, para eles, como que as mais ofereceram ferramentas que contribuíram para a aprendizagem, o diferencial foi a disponibilidade de vídeo aula, áudio, este último como possibilidade de ser ouvido em MP3 em qualquer lugar, os slides, os testes rápidos, os fóruns da disciplina. Destaque para outro depoimento que diz que essas disciplinas estiveram mais próximas deles.

As demais disciplinas foram destacadas com menor freqüência, mas justificadas como as que apresentaram ferramentas que melhor contribuíram para a aprendizagem deles, pelo fato de utilizarem como estratégias metodológicas algumas atividades pedagógicas como o Seminário, que promove o encontro entre os alunos na elaboração e defesa dos trabalhos; pelos slides. Destacamos que alguns alunos elegeram disciplinas por acreditarem que quando se tem familiaridade com a disciplina, há uma efetiva contribuição para a aprendizagem.

Merece nossa atenção o fato de algumas disciplinas oferecerem atividades com feedback ser considerado como pelos alunos ponto positivo para sua melhor aprendizagem. 
Diante dessas considerações, observamos que a pesquisa resulta no fato de alunos não terem consciência da importância das ferramentas tecnológicas para a construção da aprendizagem colaborativa.

Se para Silva (2006) e Belloni (2006), interatividade são mecanismos que potencializam o diálogo entre as partes com vistas à intervenção, o diálogo para uma construção coletiva do conhecimento, para os alunos do Curso de Administração a Distância a idéia de interatividade ainda não está muito clara, conforme observamos na pesquisa.

No entanto, esses alunos reconhecem as disciplina que investem nos recursos tecnológicos como forma de promover a interatividade e interação, razão pela qual eles atribuírem serem ferramentas interativas, aquelas que promovem a comunicação.

Portanto, para esses alunos a possibilidade do debate, do diálogo, da intervenção enquanto ações que promovem a reelaboração do conhecimento, ainda estão distantes do seu cotidiano acadêmico.

\section{Considerações finais}

Para uma educação de qualidade, seja a distância ou presencial, propomos uma educação que efetivamente tenha o foco voltado para a aprendizagem. E, em especial para a modalidade a distância que sua organização esteja centrada na modelagem do ambiente, na mediação pedagógica e no planejamento de atividades pautadas na reelaboração do significado com investimento em ações que valorizem a interatividade permitida pelos dispositivos tecnológicos.

Todavia, o papel do professor éfundamental nesse processo, pois ele é responsável pelo planejamento de atividades que promovam 
no aluno o pensamento crítico. É responsável por estimulá-los quanto à progressão dos estudos, pela promoção da maturidade e autonomia, aspectos necessários para que o aluno possa intervir em prol de uma melhor e maior participação na sociedade.

Operacionalmente, muitas dessas situações podem ser efetivadas com uma gerência comprometida com a concepção sóciointeracionista. O Ambiente Virtual - Moodle - já foi programado para essa possibilidade, mas ele não opera se não têm pessoas-professores por trás que tenham essa definição pedagógica.

Por tudo isso, concluímos este trabalho na perspectiva de que os cursos a distância considerem a possibilidade de viabilizar a disseminação da cultura sóciointeracionista, sobretudo, junto aos alunos, de forma que eles compreendam com a própria vivência o que significa uma ação interacionista, e assim possam intervir para melhor qualidade do seu curso.

Todavia, evidenciamos que esta discussão não se esgota com este trabalho. Há a pretensão de continuar os estudos, investigando outros atores desse processo, especificamente, os professoresformadores que têm papel fundamental nessa história, mas que também possuem limitações.

\section{Referências}

ASSMANN, H. (Org.). Redes digitais e metamorfose do aprender. Petrópolis: Vozes, 2005.

BELLONI, M. L. Educação a distância. Campinas, SP: Autores Associados, 2006.

BOGDAN, R.; BIKLEN, S. Investigação qualitativa em educação.

Porto: Porto, 1994. 
CHIZZOTTI, A. Pesquisa em ciências humanas e sociais. 4. ed. São Paulo: Cortez, 2000.

COLAÇO, V. de F. R. Processos Interacionais e a Construção de Conhecimento e Subjetividade de Crianças. 2004. Disponível em: $<$ http://redalyc. uaemex.mx/redalyc/pdf/188/18817306.pdf $>$. Acesso em: 2 out. 2007.

FerreirA, A. B. de H. Novo Dicionário da Língua Portuguesa. 2. ed. Rio de Janeiro: Nova Fronteira, 1986.

FERREIRA, S. de L.; BIANCHETTI, L. As tecnologias da informação e da comunicação e as possibilidades de interatividade para a educação. Revista da FAEEBA, Salvador: UNEB, v. 13, n. 22, p. 253-263, 2004. Disponível em: <http://www.revistadafaeeba.uneb.br/anteriores/ numero22.pdf >. Acesso em: 15 abr. 2008.

FIORENTINI, L. M. R; MORAES, R. de A. (Orgs.). Linguagens e Interatividade na Educação a Distância. Rio de Janeiro: DP\&A, 2003.

GIL, A. C. Como elaborar projetos de pesquisa. 4. ed. São Paulo: Atlas, 2007.

KOCH, I. G. V. Desvendando os segredos do texto. São Paulo: Cortez, 2002.

KENSKI, M. V. Educação e tecnologias: o novo ritmo da informação. Campinas, SP: Papirus, 2007.

LÉVY, P. Cibercultura. 2. ed. São Paulo: Editora 34, 2000.

LUDKÉ, M.; ANDRÉ, M. E. D. A. Pesquisa em educação: abordagens qualitativas. São Paulo: Editora Pedagógica e Universitária, 1986.

MACHADO, A. Pré-cinemas \& pós-cinemas. Campinas,SP: Papirus, 1997. 
MORAN, J. M.; MASETTO, M. T.; BEHRENS, M. A. Novas tecnologias e a mediação pedagógica. Campinas, SP: Papirus, 2000.

. O que é Educação a distância. 2002. Disponível em: <http:// www.eca.usp. br/prof/moran/dis.htm>. Acesso em: 18 jun. 2008.

MUZINATTI, C. M. A. Mundo moodle: conhecimento em construção. 2005. Disponível em: <http://cidade.usp.br/redemoinhos/?2005-03/ fundamental>. Acesso em: 4 mai. 2008.

OLIVEIRA, M. K. de. Vygotsky: aprendizado e desenvolvimento, um processo sócio-histórico. 4. ed. São Paulo: Scipione, 1999.

Pensar a educação contribuições de Vygotsky. In: CASTORINA, J. A. et al. Piaget-Vygotsky: novas contribuições para o debate. 6. ed. São Paulo: Ática, 2003.

PEREIRA, E, W. Educação a distância: concepção e desenvolvimento. 2003. Disponível em: <http://www.fe.unb.br/linhascriticas/n17/ educacao_a_distancia.

html>. Acesso em: 2 out. 2007.

PRIMO, A. Ferramentas de interação na web: travestindo o ensino tradicional ou potencializando a educação através da cooperação? Disponível: <http://www.c5. cl/ieinvestiga/actas/ribie2000/papers/210/index.htm >. Acesso em: 18 mai. 2008.

PULINO FILHO, A. R. P. Moodle: Um sistema de gerenciamento de cursos. Brasília: Universidade de Brasília, Departamento de Engenharia Civil e Ambiental. 2005. Disponível em: <http://www.aprender.unb.br/>. Acesso em: 8 abr. 2008.

RICHARDSON, R. J. et al. Pesquisa social: métodos e técnicas. 3. ed. São Paulo: Atlas, 1999.

SILVA, M. (Org.). Educação online. São Paulo: Loyola, 2003. 
Sala de aula interativa. 4. ed. Rio de Janeiro: Quartet, 2006.

UNIVERSIDADE ESTADUAL DA PARAÍBA. Coordenação Institucional de Programas Especiais - CIPE. Projeto do Curso de Administração a Distância. Campina Grande: UEPB, 2005.

VAN DER LINDEN, M. M. G. Diálogo didático mediado on-line: subsídios para sua avaliação em situações de ensino-aprendizagem. 2005. 261f. Tese (Doutorado em Engenharia de Produção) - Universidade Federal de Santa Catarina, Florianópolis, 2005

VYGOTSKY, L. S. Pensamento e linguagem. São Paulo: Martins Fontes, 1988.

A formação social da mente: o desenvolvimento dos processos psicológicos superiores. São Paulo: Martins Fontes, 1998. 


\section{Tutoria: concepções e práticas na educação a distância}

\section{Mayam de Andrade Bezerra}

UEPB - Campina Grande, Paraíba mayam.uepb@yahoo.com.br

\section{Ana Beatriz Gomes Carvalho}

UEPB- Campina Grande, Paraíba anabeatrizuepb@gmail.com

\section{Introdução}

A expansão da educação a distância, na última década, e o interesse por esta forma particular de ensino e aprendizagem aumentaram de forma notável em muitos países. Especialistas de diferentes áreas começam a enxergar as possibilidades dessa modalidade de ensino. E, além disso, as universidades tradicionais começam a experimentar a educação a distância depois de ignorar por muito tempo essa modalidade educacional.

Na opinião de Peters (2003), o principal motivo para o crescente interesse na educação a distância são, obviamente, os avanços inacreditáveis na telecomunicação, juntamente com as tecnologias digitais que possibilitam vantagens logísticas e pedagógicas 
inesperadas, como por exemplo: a transmissão rápida de informações a qualquer momento e para toda parte, genuínas possibilidades para a aprendizagem autônoma, maior interatividade, mais orientação para os/as estudantes, maior individualização, melhor qualidade dos programas e maior eficácia da aprendizagem.

A EAD atualmente experimenta um crescimento e uma eficácia pedagógica sem precedentes e desponta com uma modalidade de ensino, na qual vem favorecendo a democratização do saber, oportunizando a inclusão digital e social, de alcance inimaginável.

A implementação de cursos na modalidade a distância em Universidades públicas, foi realizada a partir das orientações operacionais da Secretaria de Educação a Distância do MEC, uma vez que os cursos de graduação a distância são financiados pelo MEC na maioria das IES públicas.

Para a efetivação dessa modalidade atua uma equipe multidisciplinar que é responsável desde a produção do material até o acompanhamento dos estudantes. As categorias e funções dos profissionais desta equipe multidisciplinar apresentam traços em comum nas diferentes instituições, embora a nomenclatura possa variar ocasionalmente. Um dos profissionais que vem sendo alvo de discussões é o tutor, profissional que atua diretamente com os alunos e cuja função ainda necessita de mais clareza nas suas atribuições. Para alguns profissionais, cabe ao tutor orientar, esclarecer dúvidas e acompanhar o estudo do aluno, enquanto para outros o tutor é um professor que deve mediar todo o processo de ensino e aprendizagem. Mas qual é realmente o papel do tutor? Ele é orientador, conselheiro, motivador ou mediador?

Diante destes questionamentos, surgiu esta pesquisa cujo objetivo foi analisar as concepções e práticas da tutoria nos cursos a distância da UEPB. O presente estudo foi realizado no polo de Campina Grande-PB, que concentra seis cursos na modalidade a distância inseridos nos projetos governamentais do Pró-Licenciatura 
(Fase 1 e 2) e na UAB (Universidade Aberta do Brasil). São cursos de licenciatura em diversas áreas do conhecimento, com exceção do curso de Administração, projeto-piloto da UAB e do fórum das estatais. A amostra foi constituída por um grupo de 4 tutores/as do curso de Administração a Distância, polo Campina Grande, e 6 tutores/as dos cursos de Física, Química e Matemática da UFRN em parceria com a UEPB.

Este estudo, de natureza qualitativa, nos possibilitou compreender o fenômeno estudado em seu contexto, uma vez que o comportamento humano é significativamente influenciado pelo contexto em que está inserido. Desse modo, pudemos entender um pouco do processo no qual as pessoas constroem significados. Segundo Minayo (1999, p. 21), "a abordagem qualitativa aprofunda-se no mundo dos significados das ações e relações humanas, um lado não perceptível e não captável em equações, médias e estatísticas".

Para a obtenção dos dados, foram utilizados os seguintes instrumentos de coleta: observação livre e entrevista semi-estruturada. A observação nos conduziu a conhecer os atos, a dinâmica espontânea dos indivíduos, suas práticas e seu cotidiano, e assim possibilitou aprofundar a compreensão do fenômeno investigado. Os dados coletados na observação foram registrados em um diário etnográfico.

As entrevistas semi-estruturadas representaram o principal instrumento de coleta. Este tipo de entrevista "parte de certos questionamentos básicos, apoiados em teorias e hipóteses” (TRIVIÑOS, 1987, p. 146). Além de favorecer a espontaneidade e a liberdade de expressão, tanto do/a entrevistado/a quanto do/a entrevistador/a, enriquecendo a investigação. Os dados obtidos particularmente nas entrevistas foram analisados através da análise temática, que consiste em uma das modalidades da análise de conteúdo. 
Conforme Triviños (1987), as questões fundamentais que compõem uma entrevista semi-estruturada resultam do embasamento teórico, suposições e informações prévias sobre o fenômeno investigado, o que justifica a escolha dos informantes. Este instrumento de obtenção de dados favorece não só a descrição, mas também a explicação e a compreensão mais ampla do fenômeno estudado.

Nessa direção, elaboramos o roteiro de entrevista a ser aplicado com os sujeitos da pesquisa, de forma a assegurar que pudéssemos acrescentar perguntas de esclarecimentos, caso necessário. As entrevistas foram realizadas com 10 tutores/as, de forma individual, e gravada em áudio. Depois, foram transcritas na íntegra.

Concluída a aplicação dos instrumentos, passamos à fase de análise dos dados. Segundo Lüdke e André (1986), a análise dos dados qualitativos requer que todas as informações obtidas durante a pesquisa sejam analisadas conjuntamente. A tarefa de análise exige, num primeiro momento, que todo material coletado seja organizado em partes procurando identificar tendências e padrões relevantes, os quais serão reavaliados, buscando relações e inferências.

Os dados obtidos particularmente nas entrevistas foram analisados através da análise temática, que consiste em uma das modalidades da análise de conteúdo. Para Bardin (1977, p.105), a análise temática objetiva desvendar o que está por trás das palavras sobre as quais se debruça, e assim "descobrir os 'núcleos de sentido’ que compõem a comunicação e cuja presença ou freqüência de aparição podem significar alguma coisa para o objetivo analítico escolhido".

Ao iniciarmos a análise, optamos por identificar os/as participantes da pesquisa com a letra $\boldsymbol{T}$, acompanhado de um numeral, dessa forma, mantivemos o sigilo da sua identidade. Em seguida, separamos as entrevistas por perguntas para podermos visualizar o discurso de cada sujeito a respeito de determinado assunto. Então, 
fizemos uma "leitura flutuante", com o objetivo de conduzir a algumas questões norteadoras. Após essa leitura, verificamos alguns elementos que se repetiam e alguns divergentes. Depois dessa etapa realizamos uma leitura mais analítica, classificando algumas unidades de sentido nos discursos dos/as entrevistados/as.

\section{Educação a Distância: um novo olhar sobre a aprendizagem}

Nesta modalidade de educação, a comunicação é um elemento fundamental e ela é mediada por diversos tipos de mídias: documentos impressos, rádio, vídeo, TV, fax e o computador. Esta modalidade de educação principalmente na atualidade apóia-se fortemente na utilização das TICs e com isso amplia consideravelmente suas possibilidades. $\mathrm{O}$ avanço tecnológico permitiu que a EAD desse um salto quantitativo com relação à disponibilização de cursos em diferentes níveis de graduação, atendendo a clientelas bastante diversificadas.

A Educação a Distância apresenta uma estrutura que modifica as relações educativas decompondo em dois momentos e dois lugares, conforme ressalta Martins e Arredondo (2001) na qual o ensino passa a ser mediatizado, a aprendizagem resulta do trabalho do estudante, a reação do aluno em face do conteúdo vem indiretamente ao docente por meio da tutoria, e a interação em sala de aula é em grande parte reduzida.

Considerando que a forma de oferecer Educação a Distância não é nova, visto que essa modalidade de ensino já existe há mais de 160 anos, tendo sido iniciada pelos ingleses nas mais diferentes áreas, via correspondência postal. Além do que, no Brasil, o ensino por correspondência já completou mais de cem anos. Mas foi a partir da promulgação da Lei de Diretrizes e Bases - 9.394, de 20 de dezembro de 1996, que foi oficializada no país esta modalidade. 
Vale ressaltar que a EAD não pode ser vista como substituta da educação convencional, presencial, pois são modalidades diferentes. A Educação a Distância possui suas especificidades, se concretizando diferente da educação presencial, sobretudo no que concerne a espaciotemporalidade. De acordo com Belloni (2006), a EAD deve ser compreendida como parte de um processo de inovação educacional amplo, viabilizado pela integração das Novas Tecnologias de Informação e Comunicação aos processos educacionais.

Peters (2003) defende a idéia de que a EAD é uma modalidade de educação com objetivos, estudantes, métodos, mídias e estratégias diferentes. Ele afirma que a situação educacional, o clima de aprendizagem, os métodos de apresentação e os métodos de aquisição do conhecimento são diferentes. Para ele não há uma interação direta entre professores e estudantes, a interação é mediada por artefatos, o processo ensino-aprendizagem ocorre predominantemente, por meio do uso da linguagem escrita, ao invés da linguagem oral e tudo isso caracteriza um rompimento com a tradição acadêmica presencial.

Tentando definir a Educação a Distância, Belloni (2006) faz uma revisão de diversos autores e constata que essa definição é construída pela descrição das principais características do que seria a EaD. Ainda a esse respeito, Sarmet (2003) em sua pesquisa de mestrado faz uma análise e aponta algumas dessas características: distância entre o professor e o aluno; ruptura temporal do processo de educação; mediação por um aparato tecnológico; flexibilidade na estruturação dos conteúdos e utilização de recursos tecnológicos; ênfase na autonomia do aluno enquanto gestor do seu processo de aprendizagem; mudanças administrativas e organizacionais.

Além disso, na EAD as atividades de ensino e aprendizagem podem ocorrer em tempo síncrono e assíncrono, o que oferece ao estudante a oportunidade de desenvolver seus estudos conforme sua disponibilidade. Dessa forma, cria um espaço de ação gerenciado pelo próprio estudante, revelando outra característica desta 
modalidade de educação, que é a centralidade do estudante no processo ensino-aprendizagem. Corroborando com esta afirmativa Carvalho (2007, p. 2-3) esclarece:

[...] a flexibilidade dos horários, a não obrigatoriedade da frequência diária, a utilização do computador como ferramenta, entre outros elementos, amplia consideravelmente o leque de pessoas que podem incluir-se em um processo de formação institucional. [...] A distância física é encurtada pelas tecnologias de comunicação que conectam professores, alunos e tutores fisicamente distantes. A ampliação do tempo de estudo está diretamente relacionada com a 'quebra' da temporalidade, já que o aluno pode acessar o material em diversos momentos, inclusive de madrugada e aos domingos. As orientações e aulas estão no ar ininterruptamente e cabe ao aluno aproveitar o momento mais adequado para interagir com o material.

Vemos que o papel do professor tem sido redimensionado, em parte devido às tecnologias, mas principalmente por causa das influências do novo paradigma educacional. Nesta perspectiva, o/a professor/a deixa de ser o único detentor do conhecimento, que ora era transmitido aos estudantes e passa a mediar esse processo de aprendizagem, problematizando, instigando e intervindo para juntos construírem o conhecimento.

Na Educação a Distância, a ação educativa do professor deve estar centrada na construção de um processo educativo alicerçado na interatividade e na criatividade, na qual deverá provocar discussões, dúvidas e instigar a aprendizagem dos estudantes.

A presença de uma equipe multidisciplinar que atua de forma cooperativa para desenvolver os cursos de graduação em Instituições 
de Ensino Superior e a tutoria, objeto de nossa investigação, desempenha papel importante, sendo o elo entre os estudantes e os docentes.

Tutoria: práticas e discursos na educação a distância

Primeiramente, para entendermos como a tutoria tem sido concebida e tratada na contemporaneidade, faz-se necessário compreendermos o que dizem alguns estudiosos sobre o assunto.

Ao fazermos uma retrospectiva histórica e uma análise terminológica da palavra tutor percebemos diferentes significados que foram sendo atribuídos ao termo no decorrer da história. A palavra tutor vem do latim tutore e sua origem está relacionada à área jurídica, significando defensor, protetor, alguém que é encarregado legalmente de exercer a tutela.

No entanto, ao ser apropriada pela Educação a Distância a tutoria ganha um novo significado e passa a ser vista como um conselheiro e também um orientador de aprendizagem do aluno solitário. Mas ao analisarmos a trajetória evolutiva dos programas de EAD no Brasil desde 1967, identificamos outras concepções de tutoria que subjazem esses projetos.

Na medida em que íamos percorrendo os programas percebemos logo em 1969, no projeto da TV Educativa do Maranhão, um Tele Ensino para alunos de $5^{\mathrm{a}}$ a $8^{\mathrm{a}}$ série do ensino fundamental, na qual o papel da tutoria era de Orientador da Aprendizagem. Também identificamos no Programa da Fundação Roberto Marinho - Telecurso 2000, e no Projeto Um Salto para o Futuro que a tutoria tinha essa mesma atribuição. Já nos programas da TV Escola e no PROINFO - Programa Nacional de Informática na Educação observamos que a tutoria cabia a função de Multiplicador. Enquanto que nos programas do SENAI/SP - Serviço Nacional de Aprendizagem Industrial a tutoria era concebida como uma Monitoria. 
Também extraímos dos estudos de Peters (2003) outro modelo tutorial, que preservava em parte a essência da tutoria em sua acepção tradicional, visto que os tutores não eram docentes, mas sim conselheiros, companheiros dos estudantes, cuja função era a de assessorá-los em questões gerais, estabelecendo uma relação pessoal com eles. A tutoria era um agregado da Universidade, sendo que este não era responsável pelo ensino, era apenas um conselheiro. Desse modo a imagem da tutoria ficava atrelada a uma pessoa que dá assistência no estudo no sentido mais restrito.

Podemos perceber que existe uma diversidade terminológica e funcional em torno deste personagem. Por vezes, o termo tutoria tem sido utilizado de forma indiscriminada, causando assim uma confusão quanto ao seu papel, visto que, ora a tutoria é concebida como conselheiro/a, guia, orientador/a, multiplicador/a, instrutor/a, companheiro/a e monitor/a. É necessário uma resignificação do termo para superar a visão de tutoria como aquela que ampara, protege, guia e defende.

Estudiosos/as como Emereciano, Souza e Freitas (2001), Martins (2001), Gonzalez (2005) e Maggio (2001) defendem que o trabalho da tutoria, apesar de apresentar suas especificidades, guarda em si a essência da ação educativa desenvolvida pelo professor, é alguém essencial, que no estabelecimento de suas mediações entre o/a estudante e as informações, fornece as direções, indica caminhos, possibilita a construção do conhecimento. Esses autores optam, inclusive, por chamar o tutor de professor-tutor.

A tutoria desempenha papel fundamental na EAD, pois apenas o uso do material didático pode não garantir a aprendizagem. Desse modo, a interação com a tutoria é uma forma de se propiciar ao estudante a distância, uma relação que apenas outro sujeito, outro ser humano pode fornecer, contribuindo com sua formação, com suas experiências, com sua subjetividade. 
Nesse sentido, para compreender o significado da tutoria Souza et al. (2004, p. 5-6) esclarecem que esta pode ser entendida,

[...] como uma ação orientadora global, chave para articular a instrução e o educativo. O sistema tutorial compreende, desta forma, um conjunto de ações educativas que contribuem para desenvolver e potencializar as capacidades básicas dos/as estudantes, orientando-os a obterem crescimento intelectual e autonomia, e para ajudá-los a tomar decisões em vista de seus desempenhos e suas circunstâncias de participação como aluno. (SOUZA et al., 2004, p. 5-6)

Por isso, que a tutoria é uma peça chave na EAD, pois esta é responsável por "garantir a inter-relação personalizada e contínua dos estudantes com o sistema. Essa ação viabiliza a articulação necessária entre os elementos do processo e a consecução dos objetivos propostos", conforme ressalta Martins (2003 apud TORRES, 2007, p. 33).

Além disso, alguns estudiosos/as buscam esclarecer o papel da tutoria nos cursos de EAD. O que realmente cabe a tutoria? Mediar todo o desenvolvimento do curso, apenas orientar os estudantes em seus estudos, esclarecer dúvidas, explicar questões relativas aos conteúdos abordados e/ou avaliar o desempenho dos estudantes em todo o processo. Essas questões inquietam os/as profissionais que trabalham com EAD, visto que por mais que cada projeto de EAD tenha um modelo de tutoria, é necessário que haja elementos constitutivos que definam esse profissional.

Percorrendo parte da literatura referente a esta temática, encontramos diversos olhares sobre o ofício da tutoria. Para Gonzalez (2005, p. 12), o papel da tutoria extrapola os limites conceituais, impostos na sua nomenclatura, uma vez que, em sua função 
precípua, ele é um educador. Conforme o autor, a tutoria é "o tênue fio de ligação entre os extremos do sistema instituição-aluno. $\mathrm{O}$ contato a distância, impõe um aprimoramento e fortalecimento permanente desse elo, sem o que, perde-se o foco".

Ainda nesta perspectiva, Silveira (2005) também concebe o/a tutor/a como um educador/a, aquele profissional que faz parte da equipe multidisciplinar da $\mathrm{EAD}$, que é responsável por discutir as estratégias de aprendizagem, suscitar a criação de percursos acadêmicos, problematizar o conhecimento, estabelecendo o diálogo com o aluno e mediando o conhecimento.

Nesse sentido, podemos perceber a amplitude das atribuições da tutoria que vão além do simples acompanhamento pedagógico. A este profissional cabe criar um ambiente que possibilite a construção do conhecimento por parte dos estudantes, buscando envolvê-los ativamente no processo de aprendizagem.

Conforme o Referencial de Qualidade para a Educação Superior a Distância, documento elaborado pela Secretaria de Educação a Distância, a tutoria desempenha papel fundamental no processo educacional dos cursos superiores a distância, uma vez que as atividades desenvolvidas a distância e/ou presencialmente contribuem para o desenvolvimento dos processos de ensino e de aprendizagem, e para o acompanhamento e avaliação do projeto pedagógico. Portanto, a tutoria deve ser compreendida como um dos sujeitos que participa ativamente da prática pedagógica. (BRASIL, 2007)

Além do que foi exposto, para Blum (2004), a tutoria deveria atuar como estimulador/a, motivador/a e orientador/a do/a estudante, devendo munir-se de todos os conhecimentos para que, virtual ou presencialmente, seja o elemento que interligará os fios cognitivos, afetivos e motivacionais necessários ao rompimento das barreiras e à extrapolação dos limites que os estudantes forem encontrando no percurso. 
Observamos que nesta perspectiva a ênfase do papel da tutoria está na sua função motivadora, assim é fundamental manter o/a estudante engajado/a com o curso, evitando que os mesmos desistam. Conforme ressalta Torres (2007, p. 34):

O papel de motivador inclui a capacidade de estimular os/as estudantes em busca de respostas e de aprofundamento, de auxiliá-los nos momentos de dúvidas e dificuldades na trajetória do curso a distância, de auxiliá-los com as dificuldades acadêmicas, tecnológicas e, muitas vezes, pessoais, de ser uma presença (mesmo que virtual) capaz de romper a solidão e o isolamento experimentado pelos estudantes a distância.

Autores como Maggio (2001), Emereciano, Souza e Freitas (2001) e Martins (2001) trazem suas contribuições e defendem que a tutoria deve atuar como mediador/a do processo de ensino e aprendizagem, problematizando o conhecimento, instigando as discussões, estimulando o pensamento crítico, a capacidade de pesquisa, contribuindo para a construção da autonomia do/a estudante. Essa postura, na concepção dos/as autores, é a mais adequada, uma vez que está fundamentada numa abordagem centrada no ato de aprender.

Nesse sentido, o professor-tutor deixa de ser o ator principal e os/as estudantes, por sua vez, tornam-se mais ativos e responsáveis pela condução de sua aprendizagem. No cenário educacional que vivenciamos, esse tipo de relação é cada vez mais estimulada, uma vez que estamos imersos em um novo paradigma educacional, que exige novas formas de ensinar.

A importância e a complexidade da posição que ocupa a tutoria dentro de um sistema de EAD exige que ele possua o domínio de uma prática política educativa, formativa e mediatizada. A figura da 
tutoria deve situar-se numa posição estratégica, já que seu desempenho central é atuar como mediador entre currículo, interesses, capacidades dos estudantes.

\section{A concepção de tutoria no campo}

A análise e interpretação dos dados desta pesquisa buscam apreender a problemática com base nas reflexões e articulações com a teoria. Assim, verificar a prática pedagógica desses tutores e seus discursos a respeito da sua atuação na EAD foi fundamental para nossa análise.

As entrevistas foram realizadas seguindo um roteiro, a partir do qual extraímos as concepções dos (as) entrevistados (as) acerca de nosso objeto de estudo. Estas concepções foram categorizadas da seguinte forma:

\section{Tutor (a) Orientador (a)}

Ao serem questionados sobre qual é o papel da tutoria, os/a entrevistados/as, de um modo geral, acreditam que a principal função da tutoria é orientar os/as estudantes em suas dificuldades. E assim se expressam:

O Tutor orienta o aluno a procurar o melhor caminho pra resolver os problemas. (T2)

Tutor é um orientador que dá algumas diretrizes, não todas, mas orienta os alunos que tem dificuldade. (T3)

Essa concepção de tutoria como orientador do processo de aprendizagem dos/as estudantes é bem presente nas propostas e práticas dos cursos a distância. Pois como já ressaltamos no capítulo II, a visão tradicional de tutor é alguém que irá aconselhar, guiar e orientar para que o estudante desenvolva sua autonomia. 
No entanto, percebemos nos discursos dos/as entrevistados/ as que a ação de orientar está em seu sentido amplo. Orientar é propor caminhos, esclarecendo percursos, de forma que favoreçam ao processo de aprendizagem dos/as estudantes.

Além disso, essa ação orientadora deve possibilitar a autonomia do/a estudante, questão primordial numa educação a distância. A esse respeito Pretti (2000, p. 27) ressalta que "o tutor, respeitando a autonomia da aprendizagem de cada cursista, estará constantemente orientando, dirigindo e supervisionando o processo de ensino e aprendizagem [...]. É por intermédio dele, também que se garantirá a efetivação do curso em todos os níveis".

$\mathrm{Na}$ educação a distância a tutoria desempenha papel fundamental, visto que por meio dela que se garante a articulação de todo o sistema de ensino e aprendizagem. Logo, a ação da tutoria não deve ser vista como um mero trabalho de acompanhamento, mas também como uma orientação individualizada e cooperativa, fundamentado numa "abordagem pedagógica centrada no ato de aprender que põe à disposição do estudante adulto recursos que lhe permitem alcançar os objetivos do curso totalmente desenvolvendo a autonomia em sua caminhada de aprendizagem", conforme destaca Delise (1999 apud MARTINS; ARREDONDO, 2001, p. 172). A esse respeito, vejamos o depoimento do/a entrevistado/a:

O trabalho da tutoria é fundamental para o sucesso dessa modalidade, porque o aluno fica muito solto, a distância, e o tutor tem papel fundamental de estar articulando, motivando, apontando caminhos para aprofundar o conhecimento. (T7)

Com certeza a ação orientadora da tutoria deve ser bem planejada, para tanto é necessário traçar estratégias de orientação, levando em consideração os conhecimentos pré-existentes, interesses e objetivos dos estudantes. Além disso, a tutoria precisa ter o 
conhecimento pormenorizado do processo de aprendizagem daqueles estudantes que estão sob sua orientação. Uma vez que ele poderá planejar estratégias de encaminhamentos e esclarecimento.

Devido à redução dos contatos pessoais entre o professor e o aluno ocorrem altas taxas de abandono na EAD. Trabalhar de modo solitário predispõe o estudante a um grande desestímulo, desse modo a importância da tarefa orientadora estar apoiada em grandes princípios durante todo o processo de orientação da tutoria. Assim, Martins e Arredondo (2001, p. 192-193) ressaltam:

1. Integralidade - levar em conta as dimensões pessoais do aluno, isto é, biológica, psiquica, social e acadêmica;

2. Universalidade - dedicar-se a todos os/as estudantes sob sua tutoria, levando em conta os ritmos diversos de aprendizagem;

3. Continuidade - orientar as tarefas de modo contínuo e ao longo do processo, sem fragmentação ou interrupções;

4. Participação - manter a coordenação e a participação entre todos os professores tutores envolvidos nos diferentes cursos, para atingir os objetivos de aprendizagem com todos os/as estudantes, sem perder a identidade das diferenças individuais nos ritmos de aprendizagem.

\section{Tutor/a professor/a}

Outro aspecto apreendido nas falas dos/as entrevistados/as é a concepção de tutor como professor. Para eles a tutoria desempenha ações educativas, visto que ele é responsável pela aprendizagem dos/ as estudantes, avalia, faz a articulação entre os demais envolvidos 
no processo, entre outras atribuições. E assim comentam de forma bem enfática:

Para mim o tutor é um professor também, a gente esclarece as dúvidas, orienta e avalia. (T10)

Nós tutores somos professores que direcionamos os alunos, orientando, fazendo um elo do professor-autor e o aluno. (T1)

Segundo Gonzalez (2005) é indiscutível que a tutoria desempenha ações educativas e como tal precisa ser considerado um professor. Ainda corroborando com esta afirmativa Maggio (2001) e Emereciano, Souza e Freitas (2001) defendem que o trabalho da tutoria guarda em si a essência da ação educativa desenvolvida pelo professor, logo estes autores/as preferem denominar de professortutor.

Precisamos considerar que a prática de tutoria deve estar pautada numa perspectiva de construção do conhecimento e não embasada num modelo tradicional de ensino transmissor de conhecimento.

Para Machado e Machado (2004) é primordial se repensar nos papéis dos principais agentes envolvidos no processo de ensino e aprendizagem num curso na modalidade à distância, principalmente o papel dos professores. Precisamos ter cuidado para que não se reproduzam nos atuais ambientes de educação a distância concepções tradicionais da figura do professor, aluno e tutor.

Desse modo, o professor deve buscar fundamentar sua prática no novo paradigma, atuando como mediador da aprendizagem, abrindo canais para as intervenções, o diálogo, problematizando de fato o saber. Atuando como mediador pedagógico, o professor estará focado na aprendizagem do aluno, assumindo que ele é o centro do processo, devendo favorecer a construção individual e coletiva do saber. 
A esse respeito um/a dos/as entrevistados esclarece que o tutor é um professor, mas seu trabalho deve estar fundamentado numa nova concepção de ensino e aprendizagem e assim comenta:

O tutor é um professor, mas é um professor numa concepção mais moderna. Que na verdade hoje quando agente fala educador, educador-professor não é mais aquele que transfere conhecimento, professor é aquele que é capaz de ajudar os alunos a construir. (T7)

No entanto, alguns sujeitos desta pesquisa ressaltam com uma certa preocupação que uma das maiores dificuldades vivenciadas neste trabalho é sobre a falta de clareza nas atribuições da tutoria, por isso que ora alguns acham que o tutor é um professor, ora acreditam que não.

Em minha opinião o papel do tutor ainda está sendo reformulado, o papel, o conceito dele, pelo menos do convívio que eu tenho cada projeto o tutor tem um certo direcionamento. (T4)

Eu acho que esta questão do papel da tutoria passa pela regularização, não existe uma função definida, isso é complicado.O tutor exerce uma função tipo auxiliar de professor. Se você tiver uma função definida ai vem a questão da valorização... Ai sim vai ser reconhecido profissionalmente.(T5)

Acho tão confuso essas atribuições da tutoria. Não existe um papel definido, a gente orienta, corrige, avalia, mas não é um professor? Isso tudo é confuso e com isso não somos valorizados enquanto profissionais do Ensino Superior.(T9)

Esse assunto é um tanto polêmico sobre as reais atribuições da tutoria, é algo que precisa ser bem esclarecido. Não basta entender o 
tutor simplesmente como alguém que vai dar um suporte. É necessário definir realmente seu papel, qual é a sua função nesse processo de construção do conhecimento na modalidade a distância.

Na literatura sobre a EAD não existe definições claras sobre as diferenças entre os papéis do professor e do tutor. A priori, não são apresentadas as tarefas atribuídas somente a um ou outro. Para alguns autores, como Belloni (2006), a tutoria é uma das funções do professor a distância. Para Maggio (2001), no entanto, a distinção entre professor e tutor seria apenas formal. Martins e Arredondo (2001) entendem como distintos o professor autor e o professor tutor. No entanto, ambos são professores na opinião destes autores.

\section{Tutor/a motivador/a}

Em diversos momentos da entrevista percebemos que a maioria dos/as entrevistados/as se referia ao tutor como um motivador, apontando como uma das principais atribuições da tutoria é motivar os estudantes em seu processo de aprendizagem. Como podemos verificar nos depoimentos a seguir:

Temos que considerar que num curso a distância se não tivesse o tutor, a desistência seria enorme, porque é a gente que está ali, marcando com o aluno, quando ele desestimula é a gente que está ali, é esse mediador, esse estimulador... (T4)

Você precisa estar motivando, indo em busca deles, saber a situação que eles estão, as dificuldades que eles enfrentam. Se você deixar o aluno solto, ai fica complicado. (T7)

Esse pensamento da tutoria como alguém que precisa estar ali estimulando, motivando é defendido por diversos pesquisadores/ as, tais como, Emereciano, Souza e Freitas (2001), Maggio (2001) 
e Gonzalez (2005). A ação da tutoria apresenta-se como o maior meio de incentivar e manter o estudante engajado no curso, devido ao diálogo e a interação que são estabelecidos entre a tutoria e os/ as estudantes.

Além de estar sempre estimulando o estudo, o desempenho e a formação do estudante e essa interação entre tutor e estudante, que acontecem de forma individual e até coletiva, favorecem as trocas afetivas mais amplas, uma vez que o acolhimento amigável e motivador impulsiona o estudante a crescer. A esse respeito Torres (2007, p. 35) esclarece:

O papel do professor-tutor não se restringe ao auxílio para a formação acadêmica, mas se expande para a compreensão das capacidades e limitações do ser humano. Ao receber demandas de natureza afetiva, aos professores-tutores não podem simplesmente dizer aos estudantes que esta esfera não lhes compete, de alguma forma eles deverão acolher a necessidade dos estudantes, quer seja visando os aspectos econômicos e institucionais de manutenção do indivíduo no curso, quer seja visando seu papel de educador.

Então, essa relação de afetividade que deve existir entre a tutoria e os/as estudantes é algo defendido na literatura e também bastante presente nos discursos dos sujeitos desta pesquisa.

$O$ aluno se desmotiva ao longo do caminho, $e$ quem vai motivá-lo a fazer os exercícios, a procurar acessar o ambiente virtual somos nós. Tudo bem que a vontade depende dele, mas se não tiver uma pessoa que dê o suporte, se não for nós é arriscado que ele se perca no processo. (T6) 
A nossa relação é de amigo, a convivência é tão grande que a gente vai aprendendo com eles. A gente interage com eles e sente os problemas. Aprendemos reciprocamente. (T10)

Os alunos têm uma ligação grande, tudo... os problemas, as dificuldades, os avanços, tudo é com o tutor. (T1)

São pertinentes os comentários dos/as entrevistados, uma vez que, muitas vezes, os/as estudantes desistem do curso por não conseguirem ultrapassar as dificuldades do estudo autônomo. Desse modo, cabe à tutoria está constantemente motivando, sugerindo atividades que criem hábitos de estudo, incentivando a autoconfiança, independência na tomada de decisões e iniciativa para que ele possa organizar sua aprendizagem.

Além disso, para que o estudante não se sinta solitário e se engaje no curso é primordial a interação constante, através dos meios de comunicação, respeitando a individualidade dos/as estudantes, incentivando o intercâmbio entre os colegas e orientando o estudo independente do aluno. Segundo Balbé (2003), sem o freqüente contato da sala de aula presencial, os/as estudantes necessitam de algum referencial para balizar seu processo de aprendizagem, nesse caso, a tutoria representa esse referencial.

\section{Tutor/a Mediador/a}

Nos depoimentos dos sujeitos desta pesquisa, outro aspecto que nos chamou a atenção foi a visão da tutoria com um elemento que promove a articulação entre os professores das disciplinas, a instituição e o próprio estudante. Como ressaltam os/as entrevistados/as:

Para mim o papel do tutor é fazer esse elo com o professor que está a distância e o aluno, fazer essa mediação...o tutor é essa ponte. (T1) 
A gente faz esse acompanhamento de saber se $o$ aluno está realmente fazendo as atividades, quais são as dificuldades, às vezes eles têm dificuldades em determinada atividade e não sabem como chegar ao professor, a gente faz esse elo, essa ponte, a ligação entre o aluno e o professor da disciplina. (T2)

Tutor deve acompanhar, apontar caminhos, ajudar a sanar determinadas dificuldades, é ser o elo de ligação entre outros componentes. (T7)

No ensino a distância o papel da tutoria é peça chave para o desenvolvimento do processo de ensino e aprendizagem, haja vista que é através da ação da tutoria, como esclarece Martins e Arredondo (2001, p. 171) que se "garante a interrelação personalizada é contínua do aluno no sistema e se viabiliza a articulação necessária entre os elementos do processo e consecução dos objetivos propostos".

Verificamos na literatura que as funções de orientação, acompanhamento, motivação, mediação e avaliação atribuídas a tutoria se entrelaçam de forma a constituir-se um corpo de atribuições bem específicas. Assim, para diversos estudiosos como Maggio (2001), Emereciano, Souza e Freitas (2001), Martins e Arredondo (2001) e Gonzalez (2005) o papel da tutoria extrapola os limites do simples "tirador de dúvidas" ou "conselheiro", pois em sua missão precípua ele é um educador. Um educador que engajado no processo de ensino e aprendizagem vai favorecer a articulação entre estudante, instituição, especialistas, professores e tutores; possibilitar a construção individual e coletiva do conhecimento; promover a interação o diálogo, a troca de experiência; incentivar ao desenvolvimento da autonomia do/a estudante; mobilizar os/as estudantes para a busca do conhecimento de forma crítica e reflexiva; estimulando-os a participarem de atividades colaborativas e cooperativas. 
Nesta perspectiva, verificamos uma aproximação das idéias preconizadas pelos sujeitos desta pesquisa e a literatura referente ao assunto abordado. Na visão deles o/a tutor/a é:

[...] um agente que colabora com a aprendizagem do aluno, acompanhando o desenvolvimento cognitivo do mesmo, proporcionando o objetivo final de cada aprendiz que é desenvolver melhor o conteúdo apresentado. (T8)

[...] é aquele que vai participar do processo de aprendizagem do aluno, a medida que ele contribui através das orientações, intervenções, fomentando o conhecimento do aluno. (T6)

Fica evidente a complexidade do papel da tutoria, cabe a ele estabelecer uma interação constante baseada no diálogo, na qual sua atuação junto aos estudantes possibilite ser um mediador, um articulador de todo esse processo de aprendizagem. É uma figura fundamental, como ressalta Pretti (1996, p. 45).

O tutor constitui um elemento dinâmico e essencial no processo ensino-aprendizagem, oferecendo aos estudantes os suportes cognitivos, metacognitivo, motivacional, afetivo e social para que estes apresentem um desempenho satisfatório ao longo do curso. Deverá, pois, ter participação ativa em todo o processo. Por isso, é importante que se estabeleça uma vinculação dialogal e um trabalho de parceria entre o tutor, o professor/especialista e a equipe pedagógica.

Para tanto, seria ideal que a ação da tutoria estivesse pautada numa perspectiva de construção do conhecimento, tendo como foco a aprendizagem, a participação dos estudantes, a interação entre eles, a pesquisa, o debate, o diálogo; favorecendo a produção do conhecimento. 


\section{Considerações finais}

Entender um pouco das concepções de tutoria identificadas nos discursos e na prática pedagógica foi decisivo para compreendermos as concepções veiculadas pelos/as tutores/as que trabalham nestes programas. Dessa forma, ao analisarmos os relatos dos sujeitos desta pesquisa fica evidente que tutoria para eles é acima de tudo um professor que atua na EAD ativamente, e assume o papel de mediador do processo de construção do conhecimento pelo fato de intermediar as ações de ensino-aprendizagem entre o professorpesquisador, o estudante e o conteúdo curricular proposto, sendo uma ligação entre o estudante e a instituição.

Além disso, a tutoria deve atuar orientando os estudantes, de forma a favorecer a construção de sua autonomia. Percebemos que essa questão da orientação é muito forte nos discursos e prática desses sujeitos. Como também é atribuída uma grande importância ao papel de motivador que a tutoria deve desempenhar, sendo justificado pelos entrevistados em virtude das características da modalidade de ensino, para que os estudantes não se desistimulem e desistam do curso, é fundamental que a tutoria esteja sempre estimulando.

Na literatura e nos documentos oficiais da Secretaria de Educação a Distância é bem claro que a tutoria deve participar ativamente de todo o processo de ensino e aprendizagem, buscando estabelecer um vínculo de parceria e interação com os demais profissionais e estudantes; além de mediar o processo pedagógico, esclarecer dúvidas, promover espaços de construção coletiva do conhecimento, participar do processo avaliativo, orientar os estudantes em questões relacionadas ao material didático, atividades, pesquisas, entre outros.

Nesta investigação nos propusemos analisar as concepções e prática da tutoria, acredito que um primeiro passo foi dado, mas 
sentimos que este estudo é um ensaio para novas pesquisas na área, tendo em vista a importância de se discutir e explorar mais essa temática.

Por fim, esclarecemos que esta pesquisa tem a intenção de se constituir em um instrumento de reflexão. Não pretendemos ser conclusiva, ou colocar um ponto final nesta abordagem, até porque isso não seria possível, diante de tantas questões que foram surgindo durante essa caminhada. Vislumbramos, sim, novas investigações acerca dessa temática tão instigante.

\section{Referências}

BRASIL. Ministério da Educação. Referenciais de qualidade para educação superior a distância. Brasília, 2007. Disponível em: <http:// portal.mec.gov.br/seed/index.php?option=com_content\&task=view\&id= 248\&Itemid=426>. Acesso em: 20 jun. 2008.

BARDIN, L. Análise de conteúdo. Lisboa: Edições 70, 1977.

BELLONI, M. L. Educação a distância. Campinas: Autores Associados, 2006.

BLUM, E. A. A Formação de formadores na educação a distância: redescobrindo o papel do professor-tutor. 2004. 189 f. Dissertação (Mestrado em Educação) - Universidade Estadual de Ponta Grossa, Ponta Grossa, 2004.

CARVALHO, A. B. G. Os múltiplos papéis do professor em educação a distância: uma abordagem centrada na aprendizagem. In: ENCONTRO DE PESQUISA EDUCACIONAL DO NORTE E NORDESTE, 18., 2007, Maceió. Anais... Maceió: EPENN, 2007. p. 2- 12. CD-ROM.

EMERENCIANO, M. do S. J.; SOUZA, C. A. L. de; FREITAS, L. G. de. Ser Presença como Educador, Professor e Tutor. Colabora, Curitiba, v.1, 
n.1, p. 4-11, agosto de 2001. Disponível em: <http://gemini.ricesu.com. br/colabora/n1/index1.htm>. Acesso em: 20 abr. 2008.

GONZALEZ, M. Fundamentos da tutoria em educação a distância. São Paulo: Avercamp, 2005.

LUDKÉ, M.; ANDRÉ, M. E. D. A. Pesquisa em Educação: abordagens qualitativas. São Paulo: Ed. Pedagógica e Universitária, 1986.

MACHADO, L. D.; MACHADO, E. de C. O Papel da tutoria em ambientes de EAD. 2004. Disponível em: <http://www.abed.org.br/ congresso2004/ por/htm/022-TC-A2.htm>. Acesso em: 10 de jan. 2008.

MAGGIO, M. O tutor na educação a distância. In: LITWIN, E. Educação a distância: temas para o debate de uma nova agenda educativa. Porto Alegre: Artmed, 2001.p. 100-110.

MARTINS, O. B.; ARREDONDO, S. C. Teoria e prática tutorial em EAD. In: MARTINS, O. B.; POLAK, Y. N. de S. A Educação a Distância na Universidade Federal do Paraná: novos cenários e novos caminhos. Curitiba: NEAD/UFPR, 2001. p. 67-89.

MINAYO, M. C. de S. (Org.). Pesquisa Social: Teoria, método e criatividade. 11. ed. Petrópolis: Vozes, 1999.

PETERS, O. A educação a distância em transição: tendências e desafios. São Leopoldo: Unisinos, 2003.

PRETTI, O. (Org.). Educação a Distância: construindo significados. Cuiabá: NEAD/IE-UFMT; Brasília: Plano, 2000.

et al. Educação a Distância: início e indícios de um percurso. Cuiabá: NEAD/IE/UFMT, 1996.

SARMET, M. M. Análise ergonômica de tarefas cognitivas complexas mediadas por aparato tecnológico: quem é o tutor na educação a distância?. 2003. 105 f. Dissertação (Mestrado em Psicologia) 
- Universidade de Brasília, 2003. Disponível em: <http://www.unb.br/ip/ labergo/sitenovo/dissertacoes/OrientJulia/MauricioS/MauricioS.pd>. Acesso em: 20 mai. 2008.

SILVEIRA, R. L. B. L. A importância do tutor no processo de aprendizagem a distância. Revista Iberoamericana de Educación. 2005. Disponível em: <http://www.rieoei.org/deloslectores/947Barros.PDF>. Acesso em: 20 jan. 2008.

SOUZA, C. A. et al. Tutoria na Educação a Distância. 2004. Disponível em: <http://www.abed.org.br/congresso2004/por/htm/088TC-C2.htm>. Acesso em: 10 de abr. 2008.

TORRES, C. C. A Educação a Distância e o Papel do Tutor:

Contribuição da Ergonomia. 2007. 198 f. Tese (Doutorado em Psicologia) - Universidade de Brasília, 2007. Disponível em: <http://bdtd.bce.unb. br/tedesimplificado/tde_busca/ arquivo.php?codArquivo=2319>. Acesso em: 8 mar. 2008.

TRIVIÑOS, A. N.S. Introdução à pesquisa em ciências sociais: a pesquisa qualitativa em educação. São Paulo: Atlas, 1987. 


\title{
As novas tecnologias da informação e comunicação na perspectiva do ensino de Geografia
}

\author{
Daniel de Brito Ricarte \\ UEPB - Campina Grande, Paraíba \\ dbricarte@gmail.com \\ Ana Beatriz Gomes de Carvalho \\ UEPB - Campina Grande, Paraíba \\ anabeatrizuepb@gmail.com
}

\section{Introdução}

A revolução técnico-científica-informacional, oriunda dos adventos contemporâneos das NTICs (Novas Tecnologias da Informação e Comunicação), é vivenciada atualmente através de inovações e tecnologias que trazem o conforto, comodidade e bem estar social, porém ainda de forma desigual.

Embora muitas dessas tecnologias venham ganhando notoriedade no cenário da sociedade de consumo, elas ainda não se popularizaram pela falta de informação e disponibilidade financeira das classes sociais menos favorecidas economicamente, como também pela ausência de investimentos na logística estrutural, na qualificação profissional ou mesmo pela resistência de alguns 
profissionais da educação que ainda possuem aversão ao novo e por isso ainda utilizam práticas didáticas um pouco ultrapassadas, visto que muitos professores ainda sintetizam uma aula pautada na descrição e na memorização de conceitos, que são somente utilizados na prova escrita e depois esquecidos pelos alunos em sua vida prática, não os levando a pensar, refletir e agir, através da consciência crítica e de ações cidadãs que elevem a qualidade de vida da sociedade.

Em decorrência de tais fatos, os professores de geografia, como cientistas sociais e educadores que interagem de forma histórica e dialética nos acontecimentos do mundo globalizado, são convocados a pesquisar, interagir, questionar, criticar e finalmente criar perspectivas sobre a estrutura e o contexto da inclusão digital voltada ao uso das NTICs no ensino da Geografia, de modo que este ensino se modifique para atender ao paradigma societal contemporâneo, através do suporte das ferramentas didático-tecnológicas, objetivando tornar a aula de Geografia mais dinâmica, interessante e interativa ao aluno.

Portanto, objetiva-se neste trabalho analisar as Novas Tecnologias da Informação e Comunicação (NTICs) na perspectiva do ensino da Geografia, através da pesquisa e análise das mesmas voltadas aos propósitos da Geografia crítica e da sua divulgação, através da criação do portal digital Geografia Online (www.geografiaonline.net), um site didático-digital que visa promover e socializar digitalmente o uso das NTICs, junto aos professores e alunos de Geografia em consonância com as transformações sócio-ambientais decorrentes da revolução técnico-científica-informacional.

\section{A aparência e organização do Portal}

Depois de inúmeras pesquisas na internet, observou-se que a quantidade de sites destinados ou relacionados com o ensino da Geografia, ainda são numericamente inexpressivos. Os 
poucos que foram encontrados apresentam conteúdos destinados ao tratamento de assuntos específicos: cartografia, geologia, geomorfologia, manejo agrícola, sensoriamento remoto, etc. Mesmo assim, nenhum deles trata da formação dos professores especificamente, no sentido de promover a socialização digital das NTICs. A partir desta análise, foi desenvolvida e apresentada a proposta de construção do portal Geografia Online.

O portal Geografia Online possui os seguintes espaços virtuais: artigos - onde são encontrados artigos educacionais, textos literários e não literários que tratam das NTICs e das experiências, relatos e projetos voltados ao ensino da Geografia. Estes artigos são divulgados por educadores e interessados pelas temáticas do portal; tutoriais - contém apostilas como, por exemplo, a do CMAP TOOLS, um programa para a elaboração de mapas conceituais; serviços - nesta área do portal são disponibilizadas informações e sugestões didáticas quanto ao uso dos serviços web, orientando os professores quanto a melhor forma de utilização dos recursos da internet na sala de aula ou no ensino a distância, tais como: fóruns, podcasts, GOOGLE MAPS, etc; softwares - são apresentados alguns softwares que podem ser utilizados para o ensino da Geografia de forma didática utilizando a internet; fórum - oferece informações e hiperlinks aos professores de Geografia, alunos e interessados na comunidade Geografia Online existente no ORKUT, visando a contribuição coletiva, integração interativa e a otimização do site, além do debate crítico, da apresentação de projetos e de experiências desenvolvidos no ensino da Geografia; vídeos - são disponibilizados vídeos educativos sobre serviços web, softwares educacionais e conteúdos voltados ao ensino da Geografia e de práticas educativas de uma forma geral; links - área do portal que possibilita a divulgação de sites relacionados com as Novas Tecnologias da Informação e Comunicação; contato - contém os e-mails do criador e dos colaboradores do portal Geografia Online, para que os educadores possam entrar em contato enviando dúvidas, críticas e sugestões para o 
constante desenvolvimento deste projeto. Os espaços virtuais do portal Geografia Online podem ser vistos na Figura 01.

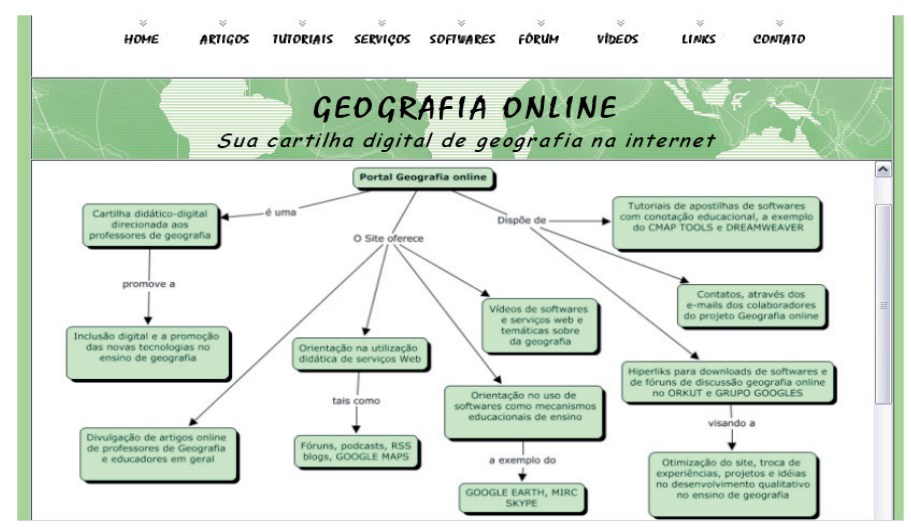

Figura 01 - Interface Gráfica da página inicial do portal Geografia Online.

Serão detalhadas a seguir, algumas das Novas Tecnologias da Informação e Comunicação que compõem este portal, incluindo a sua definição, possibilidades e perspectivas pedagógicas destes recursos.

\section{Os fóruns e seus mecanismos didáticos de comunicabilidade na aprendizagem}

Como o próprio nome sugere, os fóruns são espaços virtuais coletivos, destinados ao debate de temas, ideias e opiniões variadas sobre os mais diversificados assuntos. No que se refere às praticas didáticas, os fóruns são ferramentas assíncronas, isto é, o usuário acessa de acordo com a disponibilidade do seu horário, proporcionando a interatividade e conforto, diante das atribuições e responsabilidades do dia-a-dia. 
Há vários tipos de fóruns presentes na internet: fóruns sobre informática, música, TV, livros, fóruns de universidades, editoras, etc. Um dos mais famosos, heterogêneo e popular no Brasil é o ORKUT. Nele os fóruns são criados dentro de comunidades com temas específicos, tais como: cidades, debate sobre política, aspectos profissionais de uma mesma área, empresa específica, grupos de educadores, enfim o uso do ORKUT se faz de acordo com o interesse de cada indivíduo, que pode variar de acordo com a sua formação e seus planos. Desse modo, Starobinas (2007), mostra que:

O uso que se faz do ORKUT depende do interesse pessoal de cada internauta e da orientação específica que ele venha a ter. $\mathrm{O}$ educador interessado em utilizá-lo precisará organizar detalhadamente a sua estratégia; para evitar a atividades excessivamente dispersivas. Deixando clara, as regras do jogo, o ORKUT pode ser um espaço de expressão e de intercâmbio de informações bastante rico em atividades educacionais (STAROBINAS, 2007, p.190).

Estas comunidades podem ser moderadas, ou seja, o participante delas somente se fará presente nos debates, mediante a aprovação dos moderadores das comunidades. Depois de efetuado o cadastro no ORKUT, um professor de Geografia pode por exemplo criar uma comunidade específica das suas disciplinas, séries ou turmas, facilitando aos alunos tirarem dúvidas, como também a explanação de ideias, debates sobre assuntos ou temáticas importantes da aula, também permite aos alunos sugerirem sites de pesquisa ou discutirem algum tema que tenha sido abordado, ou seja, os fóruns levam os alunos a debater, se informar, participar, pensar, e emitir a sua opinião sobre uma questão levantada. A interface gráfica do ORKUT pode ser vista na Figura 02. 


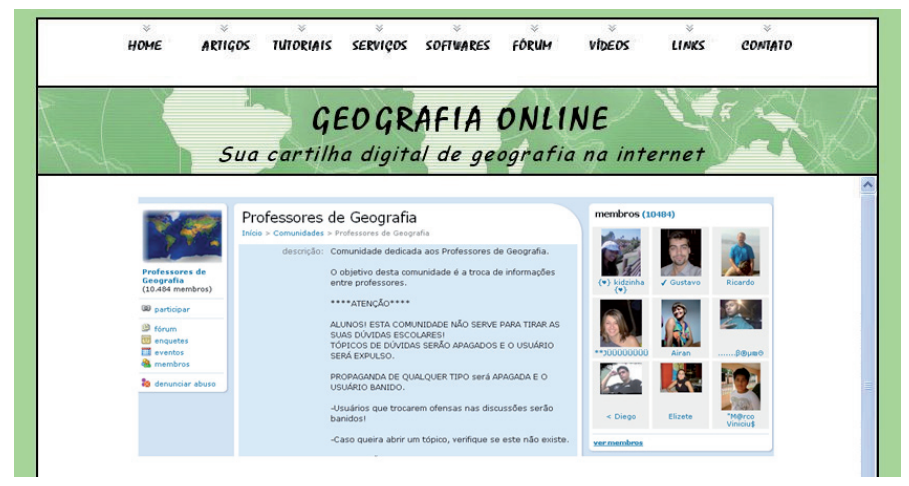

Figura 02 - Comunidade de professores de Geografia no ORKUT

Outra forma interessante de se promover a comunicabilidade virtual, porém de forma síncrona em tempo real, são as salas de papo virtuais, os chamados chats. Neles os alunos podem conversar e estreitar a sua convivência interpessoal através das salas de bate-papo que promovem a socialização e uma maior interação das relações humanas.

\section{0 uso dos mapas conceituais no ensino de Geografia}

A transmissão e a aprendizagem de distintos conhecimentos na construção do pensamento, traz ao educador a necessidade de aplicar novas técnicas didáticas que facilitar o desenvolvimento cognitivo dos seus alunos, onde o nível de aprendizagem será crucial para a aquisição dos conhecimentos no processo de ensino-aprendizagem. Diante disso, além da leitura e interpretação de textos, figuras, entre outros recursos didáticos, deve-se levar em conta também a importância da explanação crítica do professor, que deve ser auxiliada por recursos didático-tecnológicos criativos, utilizando imagens e símbolos que proporcionem uma interação construtivista do aluno que ao visualizar uma imagem, possa interligar as ideias, representando a construção associativa do 
conhecimento. A seguir, será apresentado na Figura 03 um exemplo de mapa conceitual que pode ser utilizado pelo professor no processo de ensino-aprendizagem em sala de aula.

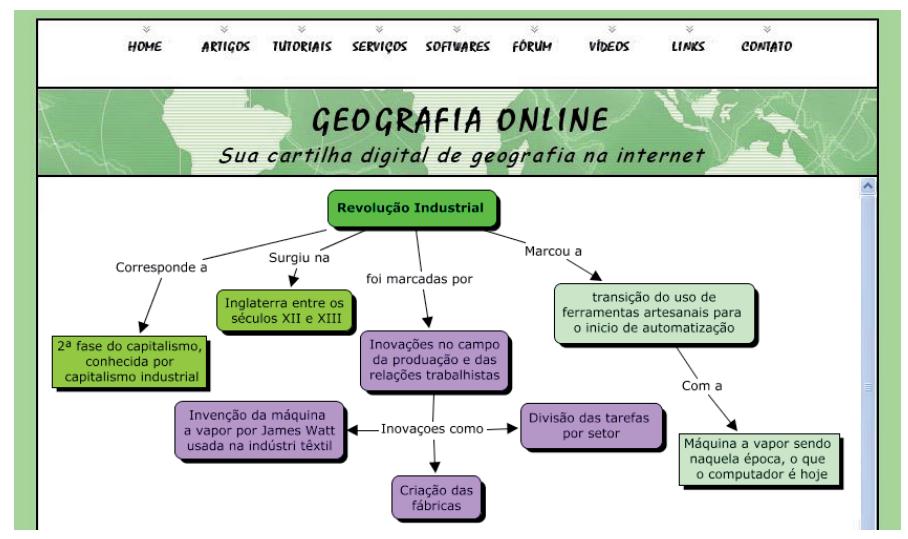

Figura 03 - Mapa conceitual da revolução industrial.

Os mapas conceituais constituem-se ferramentas indispensáveis para a construção hierárquica e associativa do conhecimento nas várias áreas do conhecimento, através de representações gráficas semelhantes aos diagramas das redes semânticas, onde o professor e o aluno podem construir seu conhecimento e representá-lo por diagramas e palavras conectadas por frases de ligação, funcionando como mecanismos na conexão das ideias no processo de aprendizagem colaborativa entre o educador e o aluno. Salienta Campos (2003, p. 1), "Este é o mecanismo de aprendizagem colaborativa onde o professor agiu como o par mais capaz de seu aluno". Neste momento o professor é o orientador, assim como o colega que conhece melhor a temática, favorecendo o crescimento e a construção do conhecimento. Assim, o professor é como um coordenador do ato de aprender que conhece melhor os conteúdos, favorecendo o crescimento e a construção da aprendizagem. Um conhecimento conceitual que na verdade é um texto que não é não linear, mas 
sim multilinear, possuindo uma dinâmica que permite ao aluno construir os conhecimentos adquiridos anteriormente, bem como as novas ideias aprendidas na sala de aula. A esse respeito, Okada (2007, p. 116) afirma que:

O texto, por ser linear, dificulta as conexões de idéias e informações. Os mapas, por terem uma estrutura gráfica, permitem que conceitos sejam registrados através de palavras chaves e relações estabelecidas através de linhas. Desse modo, a interface gráfica de um mapa torna-se mais fácil para trazer conceitos cujas relações podem ser estabelecidas sem a ordem predefinida e de modo multi-linear.

Os mapas conceituais constituem uma forma de ensino dinâmico que pode motivar a compreensão de velhos e novos conceitos, pois a medida que a aluno representa seus conhecimentos de uma forma sequencial e organizada, novas ideias surgem e outros conhecimentos são relacionados à estrutura cognitiva de sua percepção intelectual, servindo de base para essa conceituação, gerando o crescimento e o domínio das informações desenvolvidas nas novas perspectivas de conhecimentos inter-relacionados e interdisciplinares.

\section{A comunicabilidade interativa e educativa do SKYPE}

O SKYPE é um programa gratuito que permite a comunicação via áudio, através da conexão VOIP (Voz sobre IP), realizando chamadas telefônicas e de videoconferência, sem nenhum custo aos usuários conectados a este software. Ele também permite que com um baixíssimo custo, o usuário possa realizar ligações para telefones fixos e celulares locais, interurbanos e internacionais. 
A qualidade do áudio é excelente, além de possuir uma agradável interface e funcionalidades simples de serem utilizadas. $O$ SKYPE dá suporte a videoconferência simultânea para pelo menos quatro pessoas com a utilização de webcam em tempo real.

Segundo a enciclopédia digital WIKIPÉDIA, “o SKYPE está disponível em 27 idiomas e é utilizado em quase todos os países”, com isso ele vem proporcionando a interatividade entre milhões de pessoas espalhadas pelo planeta. Nele é possível enviar arquivos, criar salas de bate papo para até 100 participantes. Os requisitos para a comunicação de áudio pela internet são: ter a disposição um computador que possua uma placa de som, um microfone, um fone de ouvido e caixas de som, além de estar conectado a internet.

Em termos educativos, o SKYPE vem sendo bem sucedido no ensino de idiomas, como também no intercâmbio entre professores e alunos do Brasil e de outros países que desejam aperfeiçoar os seus conhecimentos. No ensino da Geografia, o SKYPE pode ser utilizado para que o professor possa tirar dúvidas dos seus alunos, proporcionando debates de conteúdos e a realização de tarefas e trabalhos em equipe com comodidade e conforto, diminuindo o tempo gasto nestas atividades.

Atualmente, o SKYPE vem ganhando notoriedade na EAD (Educação a distância) através do TALKANDWHITE, um aplicativo educacional complementar do SKYPE, que foi desenvolvido no Brasil, mais especificamente em Santa Catarina, de acordo com o Portal Fator Brasil (2008),

Reconhecido pelo Ministério da Educação (MEC), o software foi desenvolvido em Santa Catarina, já possui milhões de usuários no exterior e hoje está conquistando também o mercado nacional de Ensino a Distância. Idealizado para uso em webconferências, a ferramenta brasileira já ultrapassou a marca de 1 
milhão de downloads desde o lançamento, há pouco mais de um ano, e ocupa atualmente a segunda posição no ranking do Skype, com média de 5 mil a 6 mil novos usuários por dia. Traduzido em 27 idiomas, o software encontrou na Europa, na Ásia e no Pacífico o principal mercado consumidor. Porém, com o crescimento da rede de Ensino a Distância no Brasil, o software, que é o único brasileiro reconhecido como aplicativo Premium no Skype, está conquistando também educadores e alunos brasileiros (PORTAL FATOR BRASIL, 2008).

Essa ferramenta permite a comunicação entre os alunos, via voz como também pela utilização e construção interativa de textos e imagens em tempo real, sendo possível que até dez pessoas trabalhem em um mesmo documento, permitindo que várias pessoas possam escrever, grifar, desenhar, apagar, fazer anotações e construir coletivamente textos virtuais que serão arquivados, impressos na tela ou papel e acessados quando o aluno desejar. Os alunos podem discutir e construir o conhecimento em tempo real, podendo expressar as suas emoções, através dos gestos e expressões faciais que o software disponibiliza. Essa ferramenta vem sendo bem utilizada do ensino de idiomas, pois trabalha dentro das quatro habilidades: ler, falar ouvir e escrever. A seguir, na Figura 04 será apresentada a ferramenta TALKANDWHITE do SKYPE. 


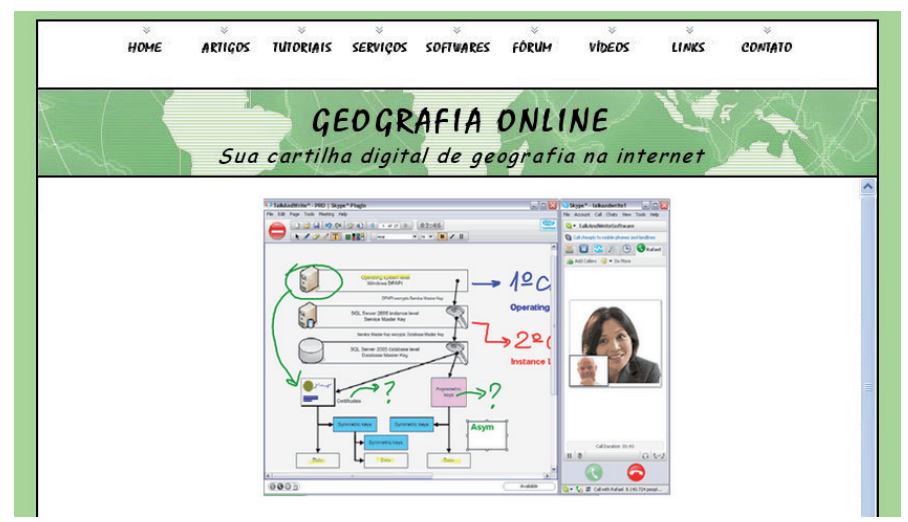

Figura 04 - Visualização da ferramenta TALKANDWHITE do SKYPE.

Sobre a óptica das práticas didáticas do ensino da Geografia, o SKYPE munido do aplicativo TALKANDWHITE, traz a perspectiva de uma melhor utilização em várias modalidades de ensino, especialmente para a Educação a Distância da Geografia, podendo ser manejada para a leitura, interpretação e análise de mapas cartográficos, fotos de satélite dos tipos de vegetação, relevo e análise de imagens de dados sobre o desmatamento. Além disso, serve para a construção simultânea e coletiva de artigos, textos e trabalhos em equipe ou mesmo debate entre os alunos e professores, quanto aos conteúdos ou dúvidas que possam por ventura surgir na aula, melhorando a perspectiva do ensino da Geografia por meio da Educação a Distância. A esse respeito, Starobinas, (2007, p. 186):

O ensino à distância é uma modalidade de ação pedagógica que pode priorizar tanto a transmissão de conteúdo de forma impessoal, quanto o acompanhamento dos estatutos de cada aluno, ou ainda utilizar-se da interação entre os participantes para catalizar o processo de aprendizagem. 
O fato de o SKYPE ser um programa de grande difusão mundial e possuir uma interface gráfica atrativa, sendo fácil de ser manuseado, facilita a sua utilização para diversos tipos de usuários. Em relação ao aplicativo complementar TALKANDWHITE, a instituição de ensino ou o professor devem adquirir a licença do software para terem acesso a versão $\mathrm{PRO}$, enquanto os alunos poderão utilizar a versão básica que é gratuita. Não é surpresa que em outros países essa ferramenta vem sendo adquirida e tornando-se suporte para uma aprendizagem dinâmica no contexto das Novas Tecnologias da Informação e Comunicação, por ser um mecanismo educativo atrativo, motivante, eficiente e colaborativo. Aos poucos, o Ministério da Educação vem elevando os investimentos na logística educacional em seus vários níveis de ensino, quem sabe essa ferramenta possa fazer parte da tão falada "revolução na educação brasileira".

\section{Os vídeos online no ensino de Geografia}

Os sites de acesso a vídeos online, principalmente o YOUTUBE e em segundo plano o GOOGLE VÍDEO são espaços virtuais em que se pode assistir a um vídeo pela internet sem a necessidade de baixar o vídeo. Este ambiente virtual possibilita a busca pelo vídeo desejado, além da integração entre os usuários que podem fazer comentários acerca dos vídeos.

Hoje, percebe-se que a maioria das câmaras digitais e dos celulares têm suporte para a realização de filmagens caseiras. Estes objetos tecnológicos vêm se tornando cada vez mais populares entre os jovens, adolescentes e adultos de várias partes do Brasil, inclusive das classes sociais menos favorecidas.

Os sites de exibição de vídeo tornaram-se bastante procurados na atualidade, diante da necessidade das pessoas de captar e guardar os momentos marcantes das suas vidas, além de compartilhar com outras pessoas as suas produções que podem ser: trabalhos pessoais, 
atividades artísticas e musicais, momentos históricos, paisagens da sua região, etc. A esse respeito, Moran (1997), verifica que:

O vídeo é também escrita. Os textos, legendas, citações aparecem cada vez mais na tela, principalmente nas traduções (legendas de filmes) e nas entrevistas com estrangeiros. A escrita na tela hoje é fácil através do gerador de caracteres, que permite colocar na tela textos coloridos, de vários tamanhos e com rapidez, fixando ainda mais a significação atribuída à narrativa falada (MORAN,1997. p.1).

No YOUTUBE ou no GOOGLE VÍDEOS os alunos podem criar vídeos "caseiros" sobre os mais diversos temas dos conteúdos da Geografia, por exemplo: vídeos que tratem dos aspectos sociais do seu bairro, das características das atividades econômicas da sua cidade, dos momentos políticos do seu município, de uma feira de ciências realizada em sua escola, etc. Tudo isso pode ser hospedado no YOUTUBE, tornando essa produção acessível aos colegas e a própria sociedade de uma maneira geral.

O interessante é que os alunos individualmente ou em grupo podem se tornar exploradores do seu espaço, observando, descobrindo e analisando as diversidades socioambientais que a sala de sala não trazia às suas mentes, desenvolvendo sua percepção social sobre a realidade em que vivem, assim tornando cidadãos críticos e ativos em termos de ideias e ações viáveis que contribuam para a percepção dos problemas de sua comunidade, gerando soluções criativas para a melhoria do ambiente em que vive.

Os professores e os alunos de Geografia ou de outras disciplinas podem fazer comentários sobre os vídeos produzidos, discutindo a temática abordada, gerando opiniões, ideias e debates com elucidação que beneficie a população que faz parte desse cenário e que tem direito a informação, politização e educação de qualidade. 


\section{Conclusão}

Este estudo prepositivo acerca das novas tecnologias no ensino de Geografia foi bastante gratificante, não somente pelo ato de pesquisar, analisar, refletir, indagar e interagir sobre essas ferramentas didático-tecnológicas de alta relevância na melhoria do ensino e das práticas didáticas dos professores de Geografia, mas também na contribuição efetiva para a maior riqueza que um povo pode conquistar, que é ter uma educação de qualidade. Hoje, a educação no país ainda é bastante necessitada de investimentos públicos, recursos logísticos e humanos que promovam a construção consciente de valores éticos, empáticos e sustentáveis. Afinal, a verdadeira grandeza de um povo é o ato de aprender, apreender e servir ao engrandecimento evolutivo do ser humano.

Neste trabalho foram analisadas algumas das Novas Tecnologias da Informação e Comunicação (NTICs) que fossem viáveis como suporte na aprendizagem do ensino da Geografia de forma dinâmica, atraente e interessante aos alunos. Além disso, foram sugeridas atividades e formas de trabalhar a utilização desses mecanismos no ensino de Geografia, sendo desenvolvido o portal didático Geografia online, uma cartilha digital que disponibiliza um leque de serviços WEB e softwares de funcionalidade educacional que tem a finalidade de socializar digitalmente os educadores de Geografia, quanto a utilização interativa e construtiva das Novas Tecnologias da Informação e Comunicação.

O portal Geografia online contará com a cooperação, participação, divulgação de textos e artigos de professores de Geografia e de profissionais de áreas científicas voltadas para a qualidade educacional. Assim, o site disponibilizará fóruns de discussão na comunidade do ORKUT, visando uma constante troca de experiência, conhecimentos e desenvolvimento didático de um ensino dinâmico, motivador e crítico da Geografia. Contudo, a melhoria dessas ferramentas dependerá essencialmente das práticas 
educativas coordenadas pelo professor, além da sua criatividade e criticidade em construir uma aprendizagem que leve o aluno a ter vontade de participar, pensar e interagir no processo de desenvolvimento das suas habilidades voltadas para o bem estar social.

Fora isso, o presente trabalho trata da novas abordagens epistemológicas, através de críticas, pesquisas, debates e a busca incessante da solução das questões sociais que fortaleçam a escola, o ensino de Geografia e revitalização da cidadania na superação de desafios e na construção de um planeta menos desequilibrado socialmente, através de soluções derradeiras que estejam dispostas ao sucesso promissor das gerações vindouras, na promoção de ações cooperativas que favoreçam o desenvolvimento econômico, tecnológico e social dos países subdesenvolvidos e em desenvolvimento, tão necessitados de um crescimento econômico equilibrado e de uma distribuição de riquezas mais equitativa, não somente em relação à renda e ao Produto Interno Bruto (PIB), mas também buscando um maior volume de investimentos financeiros que possam promover à inclusão social, o acesso à informação e a consolidação de uma educação voltada a formação intelectual de uma sociedade crítica.

\section{Referências}

CAMPOS, G. H. B. Mapas conceituais e EAD. 2003. Disponível em: $<$ http://www.timaster.com.br/revista/colunistas/ler_colunas_emp. asp?cod=730>. Acesso em 16 de nov. 2008.

OKADA, A. L. Mapas conceituais em projetos e atividades pedagógicas. In: Moraes, U. C. Tecnologia Educacional e Aprendizagem: o uso dos recursos digitais. 2. ed. São Paulo: Livro pronto. p. 115 a 127.

MORAN, J. M. O vídeo na sala de aula. 1997. Disponível em: <http:// www.eca.usp.br/prof/moran/vidsal.htm> Acesso em 15 de Nov. 2008. 
OKADA, A. L. Mapas Conceituais em projetos e atividades pedagógicas. In: MORAES, U. C. Tecnologia educacional e aprendizagem: o uso dos recursos digitais. São Paulo: Livro Pronto, 2007. p. 115 - 127.

PORTAL FATOR BRASIL. Tecnologia brasileira ganha espaço na educação a distância. 2008. Disponível em: <www.revistafatorbrasil. com.br/ver_noticia.php?not=28980 >. Acesso em: 16 de Nov. 2008.

STAROBINAS, L. Interação de professores em fóruns eletrônicos: um estudo de caso do programa Educar na Sociedade da Informação. 2008. Tese (Doutorado em Educação) - Universidade de São Paulo, São Paulo, 2008.

STRATOBINAS, L. 0 caminho das pedras: colaboração em redes digitais. In: MORAES, U. C. Tecnologia educacional e aprendizagem. São Paulo: Livro Pronto, 2007. p. 183 - 200.

\section{(Footnotes)}

${ }^{1}$ Esta aula faz parte da $2^{\mathrm{a}}$ edição juntamente com as aulas 09 e 14 . Não apresentam sub-temas. 



